ESTER TSENG

\title{
RECICLAGEM TOTAL DE PAVIMENTOS DE CONCRETO COMO AGREGADOS PARA CONSTRUÇÃO DE NOVOS PAVIMENTOS DE CONCRETO: O CASO DO RODOANEL METROPOLITANO MÁRIO COVAS
}


ESTER TSENG

RECICLAGEM TOTAL DE PAVIMENTOS DE CONCRETO COMO AGREGADOS PARA CONSTRUÇÃO DE NOVOS PAVIMENTOS DE CONCRETO: O CASO DO RODOANEL METROPOLITANO MÁRIO COVAS

Dissertação apresentada à Escola Politécnica da Universidade de São Paulo como requisito para a obtenção do título de Mestre em Engenharia

Área de Concentração: Engenharia de Transportes - Infra-estrutura de Transportes

Orientador: Prof. Dr. José Tadeu Balbo 
FICHA CATALOGRÁFICA

Tseng, Ester

Reciclagem total de pavimentos de concreto como agregados para construção de novos pavimentos de concreto: 0 caso do Rodoanel Metropolitanio Mário Covas / E. Tseng. -- São Paulo, 2010.

$220 \mathrm{p}$.

Dissertação (Mestrado) - Escola Politécnica da Universidade de São Paulo. Departamento de Engenharia de Transportes.

1. Pavimentação (Reciclagem) 2. Pavimentos rígidos 3. Agregados (Reciclagem) 4. Sustentabilidade 5. Tecnologia do concreto I.Universidade de São Paulo. Escola Politécnica. Departamento de Engenharia de Transportes II. t. 


\section{AGRADECIMENTOS}

A Deus, razão do meu viver, a quem eu devo e confio toda minha vida.

À minha família, meu pai, minha mãe, meus irmãos e amigos, que sempre acreditaram em mim.

Ao meu orientador, Prof. José Tadeu Balbo, pelo seu empenho e dedicação durante o meu mestrado; por todos os conselhos, pelas conversas e discussões, pelo seu apoio e confiança, e por acreditar no meu potencial me abrindo inúmeras portas.

Ao Laboratório de Caracterização Tecnológica, professor Henrique Kahn e todos os seus funcionários, em especial Carina e Erílio, por disponibilizarem toda sua infraestrutura para que eu pudesse realizar meu trabalho, pela paciência em me ensinar, pela ajuda no laboratório, pelo apoio e incentivo, e principalmente pela amizade.

Ao Laboratório de Tecnologia de Pavimentação, professora Liedi Bernucci, Edson, Erasmo e Kendi, que sem hesitar me ajudaram em tudo que puderam.

Ao Laboratório de Construção Civil do PCC e seus funcionários, em especial Adilson.

Ao pessoal do Laboratório de Microestrutura do PCC, especialmente ao Bruno, pelo companheirismo e disposição em ajudar.

Ao Laboratório de Mecânica das Rochas, prof. Carlos Eduardo Sansone e Jorge Sakamoto pela extração dos corpos de prova.

Ao eng. Assis Villela da CCR, por todo seu empenho em coletar e transportar o material do Rodoanel para minha pesquisa.

À Britex, pela britagem primária do material. 
À Holcim Brasil S/A, eng. José Wanderlei de Abreu e toda sua equipe, em especial Donizete, Fernando, Chico e Márcio; por disponibilizarem materiais e infraestrutura para as moldagens e para os ensaios de módulo de elasticidade em compressão

À pedreira Embu, em especial ao Renato, pela doação dos agregados naturais empregados no concreto de controle.

À minha banca examinadora, Prof. Dr. Vladimir Antonio Paulon e Dr. Sérgio Cirelli Angulo, por todas as sugestões e críticas, que foram essenciais para 0 desenvolvimento do trabalho.

À CAPES e à FAPESP pela bolsa de mestrado e ajuda financeira na compra de materiais.

A todos os professores que estiveram sempre dispostos a tirar minhas dúvidas, em especial professores Antônio Figueiredo, Maria Alba Cincotto e Vanderley John.

Aos meus colegas de laboratório, Paulo, Virgínia, Taís, Maria, Rafael, Glenda e André.

E finalmente ao time de vôlei da Poli, agradeço o exemplo de perseverança, disciplina e dedicação dessa equipe, e pela satisfação de poder fazer parte desse grupo durante o meu mestrado. 
Confie no Senhor de todo o seu coração e não te estribes no teu próprio entendimento. Reconhece-o em todos os teus caminhos, e Ele endireitará as tuas veredas.

(Provérbios 3: 5 e 6)

Feliz é o homem que acha sabedoria, e o homem que adquire conhecimento; porque melhor é o lucro que ela dá do que o da prata, e melhor a sua renda do que o ouro mais fino. 


\section{RESUMO}

O estudo da reciclagem de pavimentos de concreto para utilização em novos pavimentos tem se mostrado de grande importância haja vista a quantidade de materiais necessários para a reconstrução dessas vias. Além do ganho ambiental, devido a uma menor extração de agregados, obtém-se um ganho econômico, com menor custo de transporte e de aquisição de materiais. O agregado proveniente da britagem de antigas placas de concreto se mostrou, historicamente, apto a ser utilizado para a produção de um novo pavimento de concreto. Entretanto, existem certas limitações, pois o seu uso não resulta em um concreto com características totalmente idênticas àquelas do concreto convencional.

O presente trabalho apresenta resultados da análise das características dos agregados produzidos através da britagem de antigas placas de pavimentos de concreto do Rodoanel Metropolitano Mário Covas em britador de mandíbula e em britador de impacto, bem como a influência do uso de agregados reciclados nas propriedades mecânicas do concreto.

No estudo comparativo entre os tipos de britador foi verificado que agregados obtidos por britador de mandíbula e por britador de impacto possuem características muito semelhantes. No estudo das características mecânicas dos concretos a resistência à tração na flexão, a resistência à tração na compressão e o módulo de elasticidade diminuíram conforme se aumentou a absorção de água ponderada dos agregados. No que se refere à resistência à compressão, contudo, não foi observada queda ao se substituir somente a fração de agregados graúdos na mistura. Quando se procedeu com a substituição da fração miúda, porém, a resistência ficou abaixo daquela do concreto de convencional.

Palavras-chave: Pavimento de concreto. Reciclagem. Agregados. Britagem. 


\begin{abstract}
The study of concrete pavement recycling for its use in new pavements has shown to be of great importance considering the quantity of materials that are necessary to reconstruct these roads. Besides the environmental gain, due to a lesser extraction of aggregates, there is also an economic gain, with smaller transportation and material purchasing costs. The aggregate originated from the crushing of old concrete slabs has historically been shown to be able to be employed in the construction of a new concrete pavement. However, there are limitations, since its utilization does not result in a concrete with the exact same properties of the conventional concrete.
\end{abstract}

The present work presents the results from the analysis of the characteristics from the aggregates produced through the crushing of old concrete slabs using a jaw crusher and an impact crusher, as well as the influence of the use of recycled aggregates on the concrete mechanical properties.

The crusher type comparative study has shown that aggregates obtained from a jaw crusher and from an impact crusher have very similar characteristics. The concrete mechanical characteristic study reveals that flexural strength, indirect tensile strength and modulus of elasticity decrease as the aggregates water absorption increase. Concerning compressive strength, however, there was no observed decrease when only coarse recycled aggregates were used. Nevertheless, when fine recycled aggregates were employed besides coarse recycled aggregates, there was a decrease in compressive strength.

Keywords: Concrete pavement. Recycling. Aggregates. Crushing. 


\section{LISTA DE ILUSTRAÇÕES}

Figura 1.1 - Chegada de concreto demolido de pavimentos ao estoque. 34

Figura 1.2 - Vista da pilha de agregados reciclados de pavimentos de concreto .... 34

Figura 1.3 - Detalhe dos agregados graúdos após classificação............................ 34

Figura 1.4 - Detalhe dos agregados miúdos após classificação ............................ 34

Figura 1.5 - Remoção de superfície de asfalto utilizando uma fresadora ................ 35

Figura 1.6 - Remoção de superfície de asfalto utilizando fresadora e pá carregadeira 35

Figura 1.7 - Exemplos de equipamento de martelo por gravidade para quebra de pavimento 36

Figura 1.8 - Equipamento de martelo hidráulico multi cabeças para quebra de pavimento 36

Figura 1.9 - Martelo a diesel montado em trailer (ACPA, 2009). 36

Figura 1.10 - Equipamento de viga vibratória para a quebra de pavimento (ACPA, 2009). 37

Figura 1.11 - Padrão típico da quebra de pavimentos de concreto antes da remoção (ACPA, 2009)

Figura 1.12 - Cortador de lança frontal utilizado para soltar os pedaços de concreto (ACPA, 2009)

Figura 1.13 - Remoção e transporte do pavimento fragmentado com o uso de uma pá-carregadeira e um caminhão caçamba (ACPA, 2009). 38

Figura 1.14 - Remoção da armadura de aço em campo ou após a britagem (ACPA, 2009). 38

Figura 1.15 - Esquema ilustrativo de vários tipos de britadores (adaptado de ACPA, 2009). 40

Figura 1.16 - Esquema do processo de reciclagem utilizado por Nagataki et al..... 44

Figura 1.17 - Variação da taxa de recuperação com o nível de processamento ..... 44

Figura 1.18 - Fluxo esquemático do sistema de reciclagem de concreto com a implantação do método HRM (adaptado de SHIMA et al., 2005) ......... 45

Figura 1.19 - Agregado reciclado de concreto 46

Figura 1.20 - Absorção de água de agregados reciclados em função do tamanho e do tempo (adaptado de EICKSCHEN e SIEBEL, 1998) 
Figura 1.21 - Curvas de distribuição de poros cumulativa de agregados naturais e reciclados (adaptado de Poon et al., 2004b)

Figura 1.22 - Curvas de distribuição de tamanho de poros diferencial dos agregados naturais e reciclados (adaptado de Poon et al., 2004b). 50

Figura 1.23 - Influência de Qw em k (adaptado de YANG et al., 2008) 58

Figura 1.24 - Desenvolvimento da consistência (adaptado de NEALEN e RUHL, 1997) 59

Figura 1.25 - Desenvolvimento da consistência através da adição de água 59

Figura 1.26 - Perda de trabalhabilidade das misturas de concreto (adaptado de POON et al., 2007)

Figura 1.27 - Percentuais de abatimento em relação à leitura inicial de cada traço (concreto de referência, concreto com $50 \%$ de agregado miúdo reciclado- AMR - e concreto com $50 \%$ de agregado graúdo reciclado AGR) (LEITE, 2001). 62

Figura 1.28 - Quantidade de agregados reciclados nas misturas de concreto R0 a R6

Figura 1.29 - Resistência à compressão normalizada com a resistência à compressão do concreto de referência $\mathrm{R} 0$ (adaptado de SPRINGENSCHMID e SODEIKAT, 1998).

Figura 1.30 - Resistência à compressão de concretos contendo diferentes combinações de agregados graúdos e miúdos (adaptado de WON, 2007 apud ACPA, 2009)

Figura 1.31 - Relação entre a resistência à compressão do concreto de controle e do concreto reciclado com substituição total dos agregados (adaptado de JUAN, 2004) 68

Figura 1.32 - Relação entre a resistência à tração indireta do concreto de controle e do concreto reciclado com substituição total dos agregados (adaptado de JUAN, 2004)

Figura 1.33 - Relação entre a resistência à tração na flexão do concreto de controle e do concreto reciclado com substituição total dos agregados (adaptado de JUAN, 2004) 69

Figura 1.34 - Módulo de elasticidade em função da relação cimento/água de concretos convencionais e reciclados (adaptado de BUILDING CONTRACTORS SOCIETY OF JAPAN, 1978 apud ACI, 2001) 
Figura 1.35 - Módulo de Elasticidade normalizado com o módulo de Young do concreto de referência R0 (adaptado de SPRINGENSCHMID e SODEIKAT, 1998).

Figura 1.36 - Relação entre a resistência à compressão e a relação a/c no concreto convencional e no concreto reciclado (adaptado de JUAN, 2004) ....... 74

Figura 1.37 - Relação entre a profundidade de carbonatação aos 91 dias e o teor de substituição de agregados miúdos naturais por reciclados (adaptado de EVANGELISTA e BRITO, 2006) 78

Figura 1.38 - Zona frontal do processo e zona de processo de rastro (adaptado de SAKAI, 1987) 85

Figura 1.39 - Coeficientes de redução para o a resistência à compressão do concreto reciclado (adaptado de JUAN e GUTIÉRREZ, 2004)...

Figura 1.40 - Resistência média à compressão dos concretos em função da relação $\mathrm{a} / \mathrm{c}$ 88

Figura 1.41 - Resistência média à compressão dos concretos em função da relação $\mathrm{a} / \mathrm{c}$ 89

Figura 1.42 - Procedimentos de mistura comparados por Tam et al. (2005) 92

Figura 1.43 - Resistência à compressão aos 28 dias para diferentes teores de substituição dos agregados utilizando o método tradicional de mistura e o método TSMA 92

Figura 1.44 - Resistência à tração na flexão aos 28 dias para diferentes teores de substituição dos agregados utilizando o método tradicional de mistura e o método TSMA 93

Figura 1.45 - Massa específica aos 28 dias para diferentes teores de substituição dos agregados utilizando o método tradicional de mistura e o método TSMA 93

Figura 1.46 - Zona interfacial no concreto misturado em duas etapas (TAM et al., 2007)

Figura 1.47 - Zona interfacial no concreto misturado pelo método tradicional (TAM et al., 2007) 94

Figura 1.48 - Estrutura após adoção dos métodos de mistura convencional, TSMAS e TSMASC 95

Figura 1.49 - Relação entre o índice de consistência, umidade inicial presente nos agregados e tempo (adaptado de NEALEN e SCHENK, 1998). 
Figura 1.50 - Desenvolvimento de rigidez no concreto com agregados naturais e no concreto com agregados reciclados saturados (adaptado de NEALEN e SCHENK, 1998)

Figura 1.51 - Resistência à compressão do concreto reciclado na Rodovia A1 Áustria. 101

Figura 1.52 - Resistência à tração na flexão do concreto reciclado na Rodovia A1 Áustria. 102

Figura 1.53 - Pavimento de concreto reciclado na rodovia Viena-Salzburg após 14 anos de sua construção (março de 2008).. 105

Figura 1.54 - Pavimento de concreto reciclado na rodovia Viena-Salzburg após 14 anos de sua construção (março de 2008).......................................... 105

Figura 2.1 - Pavimento de concreto do Rodoanel............................................. 112

Figura 2.2 - Placas de concreto retiradas do Rodoanel ..................................... 112

Figura 2.3 - Barra de transferência .............................................................. 113

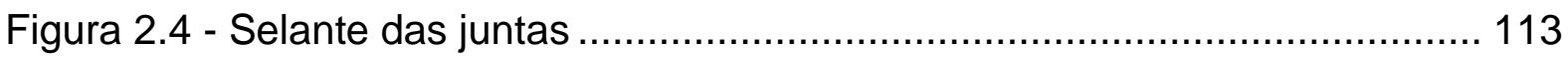

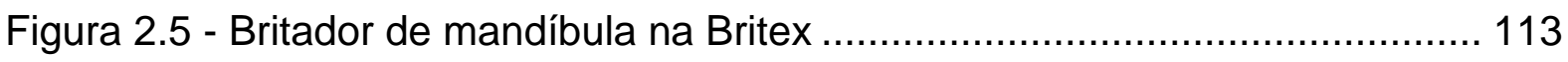

Figura 2.6 - Esteiras rolantes que levam o material às pilhas............................... 113

Figura 2.7 - Fração "rachão" obtida após britagem primária ................................... 114

Figura 2.8 - Fração "pedra 2" obtida após britagem primária................................ 114

Figura 2.9 - Fração "pedra 1" obtida após britagem primária................................ 114

Figura 2.10 - Fração "pedrisco com areia" obtida após britagem primária............. 114

Figura 2.11 - Fração "areia" obtida após britagem primária .................................. 114

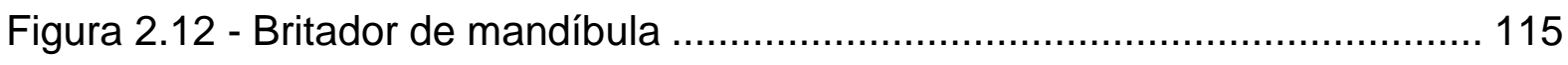

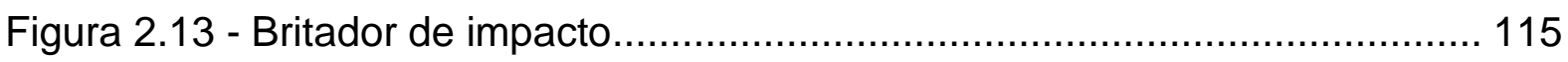

Figura 2.14 - Pilha de homogeneização …………............................................ 116

Figura 2.15 - Quarteador tipo Jones ....................................................... 116

Figura 2.16 - Máquina e esferas metálicas utilizadas no ensaio de abrasão "Los Angeles".

Figura 2.17 - Montagem de equipamento para realização do ensaio de absorção de

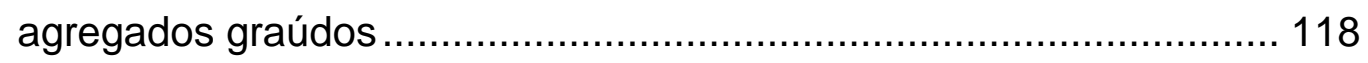

Figura 2.18 - Espectrômetro Magix Pro da PANalytical (foto cedida pelo LCT).... 119

Figura 2.19 - Moinho de rolos (ULSEN, 2006) ............................................... 119

Figura 2.20 - Moinho de discos oscilantes (ULSEN, 2006) ................................ 119

Figura 2.21 - Máquina de fusão (foto cedida pelo LCT) .................................... 120 
Figura 2.22 - Curvas granulométricas dos agregados segundo o método de britagem utilizado.

Figura 2.23 - Curvas granulométricas dos agregados graúdos segundo o método de britagem utilizado

Figura 2.24 - Curvas granulométricas dos agregados miúdos obtidos segundo o método de britagem utilizado.

Figura 2.25 - Absorção de água dos agregados graúdos por fração e tipo de britagem

Figura 2.26 - Porosidade aparente dos agregados graúdos por fração e tipo de britagem

Figura 2.27 - Massa específica aparente dos agregados graúdos por fração e tipo de britagem 124

Figura 2.28 - Teor de $\mathrm{SiO}_{2}$ nas amostras obtidas através de britador de impacto e de mandíbula 126

Figura 2.29 - Teor de $\mathrm{CaO}$ + perda ao fogo nas amostras obtidas através de britador de impacto e de mandíbula.

Figura 3.1 - Montagem dos equipamentos para o ensaio proposto por Damineli (2007)

Figura 3.2 - Esquema dos períodos de secagem obtidos através dos dados de secagem em microondas (linhas vermelhas) e do método de determinação da $M_{S}$ (linha verde)

Figura 3.3 - Esquema da determinação da absorção $(A)$ no ponto de intersecção entre fases de secagem I e II (DAMINELI, 2007)

Figura 3.4 - Curvas granulométricas dos agregados utilizados no concreto estudado 135

Figura 3.5 - Curvas granulométricas dos agregados graúdos utilizados no concreto estudado 135

Figura 3.6 - Curvas granulométricas dos agregados miúdos utilizados no concreto estudado 136

Figura 4.1 - Curva granulométrica dos agregados miúdos convencionais. 140

Figura 4.2 - Resistência à tração na flexão para o concreto convencional de dosagem

Figura 4.3 - Resistência à compressão simples para o concreto convencional de dosagem 
Figura 4.4 - Determinação da consistência do concreto pelo abatimento do tronco de cone

Figura 4.5 - Recipiente de medida de teor de ar incorporado ............................. 152

Figura 4.6 - Montagem da prensa para realização do ensaio de 2 cutelos............ 153

Figura 4.7 - Ensaio de tração por compressão diametral

Figura 4.8 - Retificação dos corpos de prova cilíndricos para ensaio de compressão direta.

Figura 4.9 - Capeamento de corpos de prova cilíndricos para o ensaio de módulo de elasticidade à compressão com mistura de enxofre 155

Figura 4.10 - Prensa servo-hidráulica e montagem para o ensaio de módulo de elasticidade à compressão 156

Figura 4.11 - Posicionamento do strain gage no ensaio de tração na flexão. 156

Figura 4.12 - Posicionamento do strain gage no ensaio de compressão diametral 157

Figura 4.13 - Posicionamento do LVDT para medição da flecha durante ensaio de tração na flexão 158

Figura 4.14 - Obtenção do módulo de elasticidade através da leitura do tempo de transmissão de onda no CP. 160

Figura 4.15 - Resistência a tração na flexão média aos 7 dias em função da absorção de água ponderada dos agregados 163

Figura 4.16 - Resistência à tração na flexão média aos 28 dias em função da absorção de água ponderada dos agregados 163

Figura 4.17 - relação entre resistência à tração na flexão dos concretos reciclado e convencional em função da absorção ponderada dos agregados...... 164

Figura 4.18 - Módulo de elasticidade aos 7 dias calculado a partir da flecha do CP MP ensaio de tração na flexão em função da absorção ponderada dos agregados 165

Figura 4.19 - Módulo de elasticidade aos 28 dias calculado a partir da flecha do CP no ensaio de tração na flexão em função da absorção ponderada dos agregados. 165

Figura 4.20 - Módulo de elasticidade aos 28 dias calculado a partir da curva tensão versus deformação obtida no ensaio de tração na flexão em função da absorção ponderada dos agregados 166

Figura 4.21 - Resistência à tração indireta aos 7 dias 169

Figura 4.22 - Resistência à tração indireta aos 28 dias 169 
Figura 4.23 - relação entre resistência à tração na compressão diametral dos concretos reciclado e convencional em função da absorção ponderada dos agregados 170

Figura 4.24 - Módulo de elasticidade aos 28 dias calculado a partir da curva tensão versus deformação obtida no ensaio de tração indireta em função da absorção ponderada 171

Figura 4.25 - Resistência à compressão aos 7 dias

Figura 4.26 - Resistência à compressão aos 28 dias 174

Figura 4.27- Relação entre resistência à compressão dos concretos reciclado e convencional em função da absorção ponderada dos agregados...... 176

Figura 4.28 - Módulo de elasticidade à compressão aos 28 dias calculado a partir da curva tensão versus deformação em função da absorção ponderada dos agregados

Figura 4.29 - módulo de elasticidade em função da resistência à compressão para concretos com incorporação de agregados graúdos reciclados 178

Figura 4.30 - módulo de elasticidade estático em função da resistência à compressão para concretos com incorporação de agregados graúdos e miúdos reciclados 178

Figura 4.31 - Módulo de elasticidade dinâmico aos 7 dias 179

Figura 4.32 - Módulo de elasticidade dinâmico aos 28 dias 179

Figura 4.33 - módulo de elasticidade aos 28 dias em função da absorção de água ponderada dos agregados 182

Figura 4.34 - Plano de ruptura dos corpos de prova de concreto contendo agregados reciclados 182

Figura 4.35- Plano de ruptura dos corpos de prova extraídos 183

Figura 4.36 - Plano de ruptura dos corpos de prova do concreto convencional ... 184

Figura 4.37 - Relação resistência à compressão e resistência à tração na flexão em função da absorção ponderada dos agregados

Figura 4.38 - índice de intensidade do ligante referente à resistência à tração do concreto aos 28 dias

Figura 4.39 - índice de intensidade do ligante referente à resistência à compressão do concreto aos 28 dias. 186 
Figura 4.40 - Intensidade do ligante em função da resistência à compressão aos 28 dias a partir de dados retirados da literatura brasileira (adaptado de DAMINELI et al.,2010)

Figura 4.41 - Extração de corpos de prova a partir de blocos de concreto retirados do Rodoanel 


\section{LISTA DE TABELAS}

Tabela 1.1 - Tipos de britadores empregados 39

Tabela 1.2 - Propriedades específicas de sistemas de britagem distintos (adaptado de EUROPEAN DEMOLITION ASSOCIATION, 1992 apud JUAN, 2004)

Tabela 1.3 - Comparação típica entre agregados naturais e agregados reciclados de concreto (adaptado de ANDERSON et al., 2009) 46

Tabela 1.4 - Comparação das propriedades do concreto com agregados reciclados em relação às do concreto com agregado natural de composição semelhante.

Tabela 1.5 - Comparação das propriedades do concreto com agregados reciclados graúdos e miúdos em relação às do concreto com agregado natural de composição semelhante 56

Tabela 1.6 - Recomendações para projetos de pavimentos de concreto contendo agregados reciclados (adaptado de ACPA, 2009) 100

Tabela 1.7 - Resultados de desempenho de pavimentos de concreto reciclados nos EUA após mais de uma década de serviço (adaptado de Sturtevant et al., 2008). 106

Tabela 1.8 - Dados médios de comparação entre seções de controle e recicladas em 2006 107

Tabela 2.1 - Frações obtidas após britagem primária na Britex. 113

Tabela 2.2 - Classificação da forma (Yoshida et al., 1972).

Tabela 2.3 - Resultados do ensaio de abrasão "Los Angeles".

Tabela 2.4 - Análise química dos agregados obtidos através do britados de mandíbula

Tabela 2.5 - Análise química dos agregados obtidos através do britados de impacto

Tabela 2.6 - Índices de forma e classificação dos agregados obtidos a partir do britador de mandíbula

Tabela 2.7 - Índices de forma e classificação dos agregados obtidos a partir do britador por impacto 
Tabela 3.1 - Resultados dos ensaios de determinação da massa específica real e aparente, absorção de água, porosidade e estimativa do teor de aglomerantes

Tabela 4.1 - Material fornecido pela pedreira Embu

Tabela 4.2 - Caracterização da areia de quartzo (Tabela cedida pela Holcim) ..... 140

Tabela 4.3 - Caracterização da areia fornecida pela pedreira Embu (Tabela cedida pela Holcim)

Tabela 4.4 - Caracterização do cimento (tabela cedida pela Holcim) 141

Tabela 4.5 - Concretos estudados 142

Tabela 4.6 - Determinação do teor ideal de argamassa para o traço 1,0:5,0 ….... 144

Tabela 4.7 - Traços definidos para etapa de dosagem....................................... 145

Tabela 4.8 - Concretos moldados para o estudo ………................................. 147

Tabela 4.9 - Resultados obtidos no ensaio de tração na flexão aos 7 dias ........... 161

Tabela 4.10 - Resultados obtidos no ensaio de tração na flexão aos 28 dias ....... 162

Tabela 4.11- Resultados obtidos no ensaio de tração na compressão diametral aos 7 dias

Tabela 4.12 - Resultados obtidos no ensaio de tração na compressão diametral aos 28 dias 168

Tabela 4.13 - Resultados obtidos no ensaio de compressão simples aos 7 dias .. 172 Tabela 4.14 - Resultados obtidos no ensaio de compressão simples e módulo de elasticidade na compressão aos 28 dias

Tabela 4.15 - Módulo de elasticidade dinâmico aos 7 dias.................................. 180

Tabela 4.16 - Módulo de elasticidade dinâmico aos 28 dias................................. 180

Tabela 4.17 - Resistência à tração na compressão diametral do concreto extraído do

Rodoanel 188

Tabela 4.18 - módulo de elasticidade dinâmico do concreto extraído do Rodoanel 


\section{LISTA DE ABREVIATURAS E SIGLAS}

a/c Relação água - cimento

ABNT Associação Brasileira de Normas Técnicas

$\mathrm{ACl} \quad$ American Concrete Institute

ACPA American Concrete Pavement Association

AGR Agregado graúdo reciclado

AMR Agregado miúdo reciclado

ASTM American Society for Testing and Materials

CAD Concreto de alto desempenho

CA Concreto asfáltico

CCP Concreto de cimento Portland

CMOD Crack mouth opening displacement (deslocamento da abertura da boca da trinca)

CMRA Construction Materials Recycling Association

CP Corpo de prova

CPs Corpos de prova

CRCP Continuously reinforced concrete pavement (pavimento de concreto continuamente armado)

CTOD Crack tip opening displacement (abertura da ponta da trinca)

DNER Departamento Nacional de Estradas e Rodagem

ECCO Environmental Council of Concrete Organizations

EPA United States Environmental Protection Agency

EPUSP Escola Politécnica da Universidade de São Paulo

EUA Estados Unidos da América

FAPESP Fundação de Amparo à Pesquisa do Estado de São Paulo

FHWA Federal Highway Administration

FRX $\quad$ Fluorescência de raios $X$

FWD Falling Weight Deflectometer

GEIPOT Grupo de Estudos em Empresa Brasileira de Planejamento de Transportes

HRM Heating and rubbing method (método de aquecimento e fricção)

IPT Instituto de Pesquisas Tecnológicas 
JPCP Joint plain concrete pavement (pavimento de concreto simples)

JRCP Jointed reinforced concrete pavement (pavimento de concreto com placas de concreto armadas)

L.A. Los Angeles

LCT Laboratório de Caracterização Tecnológica da Escola Politécnica da Universidade de São Paulo

LMP Laboratório de Mecânica de Pavimentos da Escola Politécnica da Universidade de São Paulo

LMR Laboratório de Mecânica de Rochas

LNEC Laboratório Nacional de Engenharia Civil de Portugal

LTP Laboratório de Tecnologia de Pavimentação

LVDT Linear variable differential transformer

Mn/DOT Minnesota Department of Transportation (Departamento de Transportes de Minnesota)

n/a Não avaliado

NBR Normalização Brasileira

NCHRP National Cooperative Highway Research Program

NE Nordeste

$\mathrm{NHI} \quad$ National Highway Institute

PCA Portland Cement Association

PCC Departamento de Engenharia de Construção Civil da Escola Politécnica da Universidade de São Paulo

PF Perda ao fogo

RI Resíduo insolúvel

RCD Resíduo de construção e demolição

RILEM Réunion Internationale des Laboratoires et Experts des Matériaux, Systèmes de Construction et Ouvrages

TSMA Two-Stage Mixing Approach (método de mistura em dois estágios)

$\mathrm{TSMA}_{S} \quad$ Two-Stage Mixing Approach with silica-fume (método de mistura em dois estágios com adição de sílica ativa)

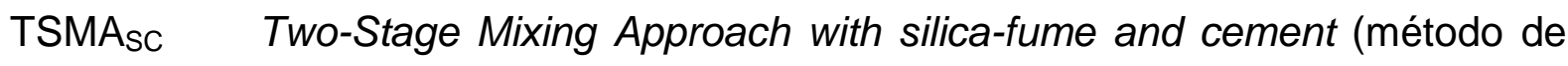
mistura em dois estágios com adição de sílica ativa e cimento)

USP Universidade de São Paulo 
VSA Valor de serventia atual

ZTI Zona de transição interfacial 


\section{SUMÁRIO}

INTRODUÇÃO E OBJETIVOS .................................................................................... 25

1. REVISÃO BIBLIOGRÁFICA................................................................................32

1.1. RECICLAGEM DE CONCRETO NA PAVIMENTAÇÃO 32

1.2. OBTENÇÃO DE AGREGADOS RECICLADOS DE CONCRETO 34

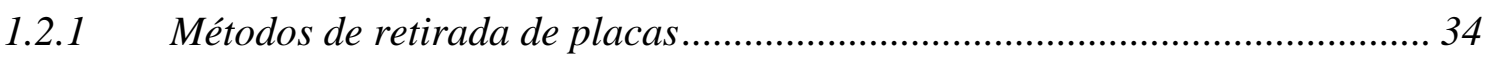

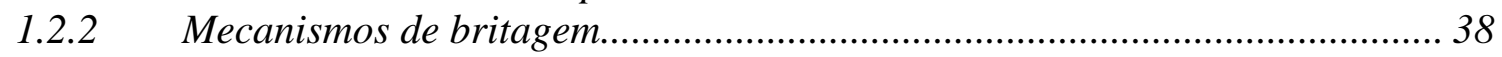

1.2.3 Vantagens e desvantagens de cada tipo de britador ......................................... 41

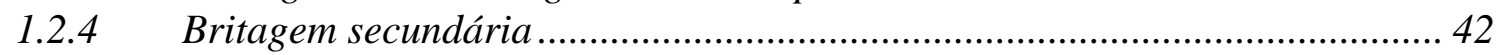

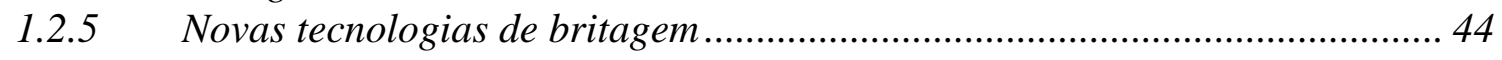

1.3. PROPRIEDADES DOS AGREGADOS RECICLADOS 46

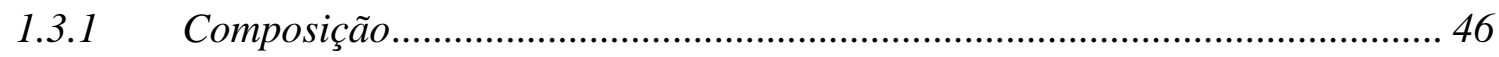

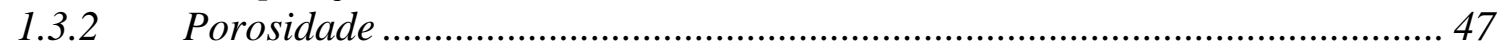

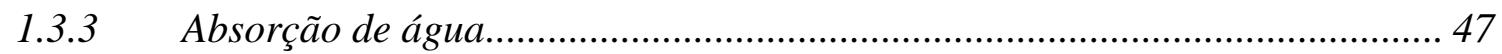

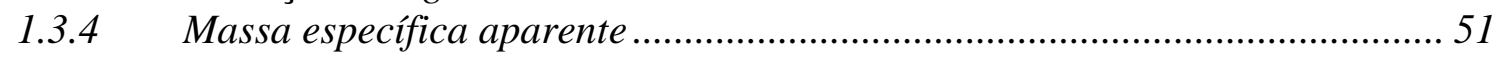

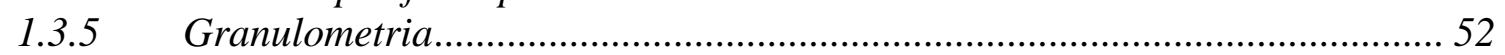

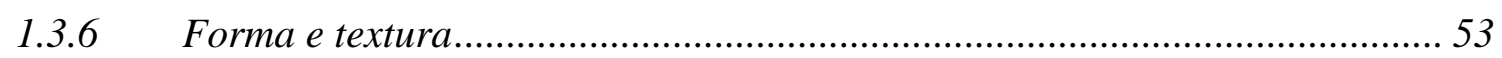

1.3.7 Índice de abrasão Los Angeles (Dureza) ..................................................... 53

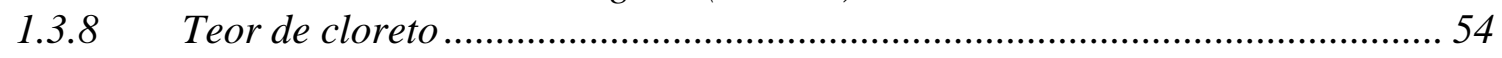

1.4. PROPRIEDADES DO CONCRETO CONTENDO AGREGADOS RECICLADOS

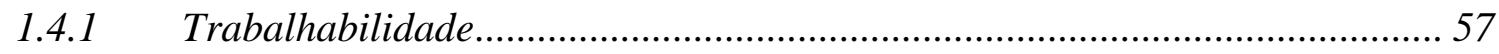

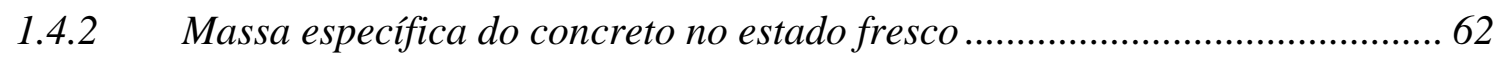

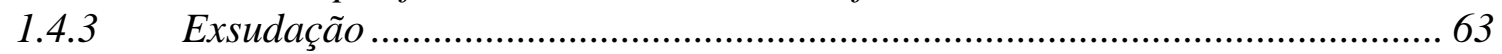

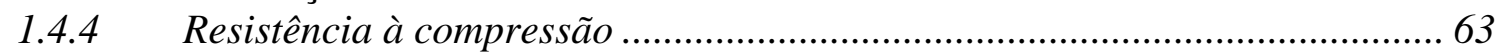

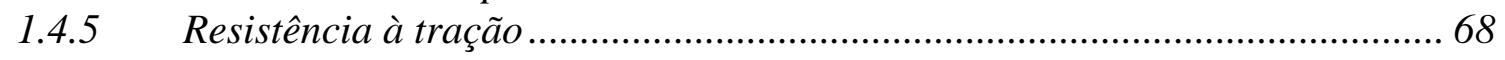

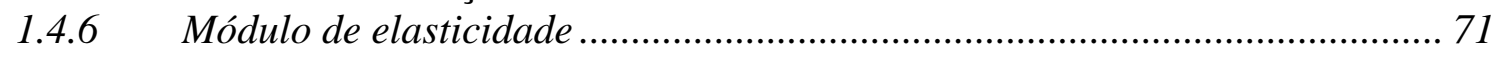

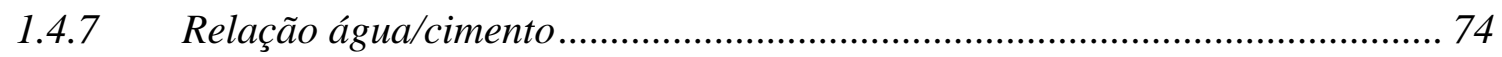

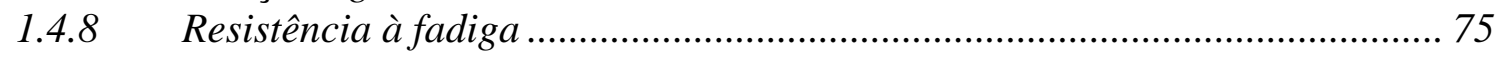

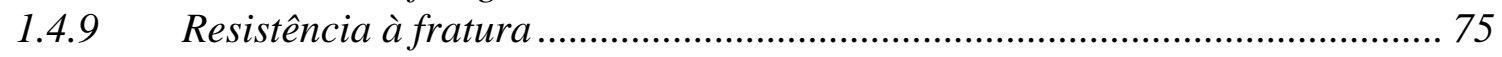

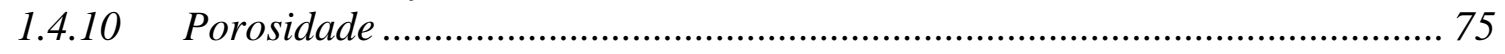

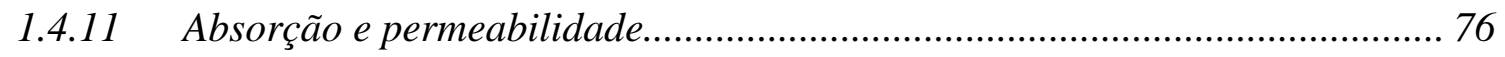

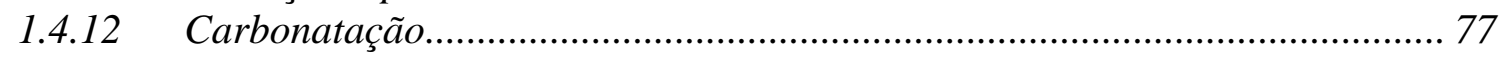

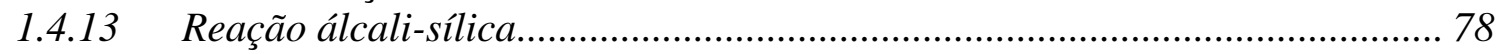

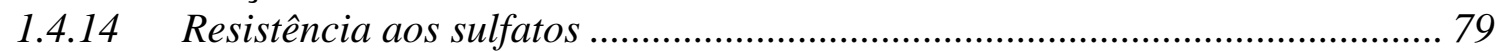

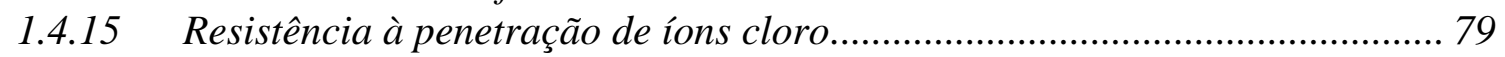

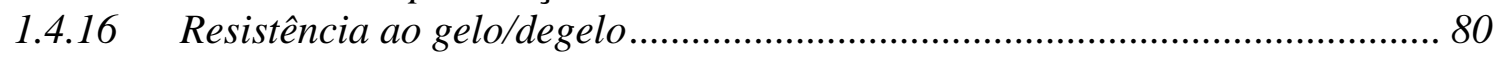

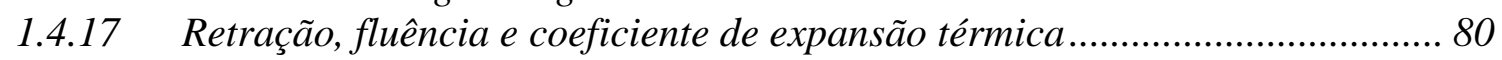

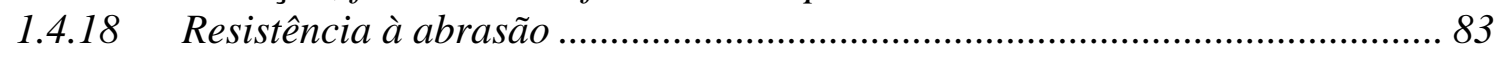

1.5. DOSAGEM DO CONCRETO CONTENDO AGREGADOS RECICLADOS 83 


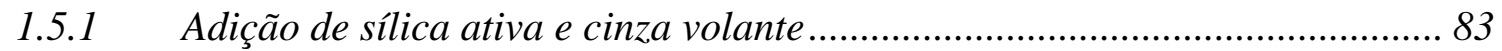

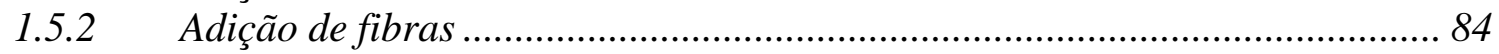

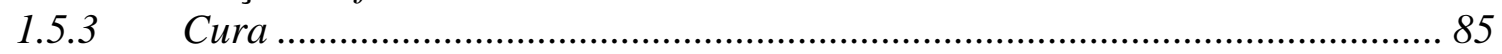

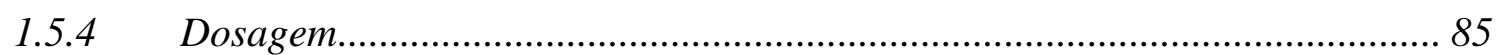

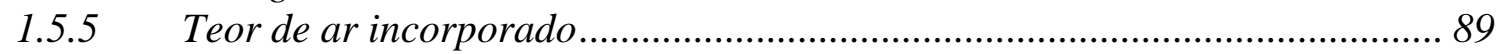

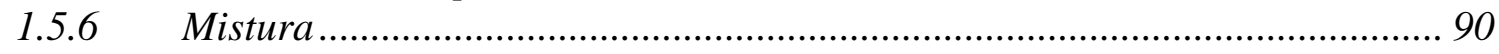

1.6. DESEMPENHO DE PAVIMENTOS DE CONCRETO CONTENDO AGREGADOS RECICLADOS 99

2. ESTUDO COMPARATIVO: BRITADOR DE MANDÍBULA E BRITADOR DE

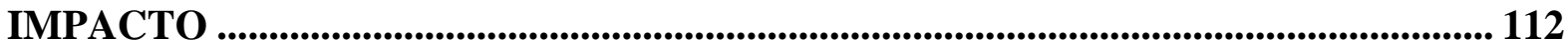

2.1. METODOLOGIA 112

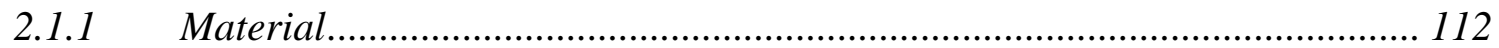

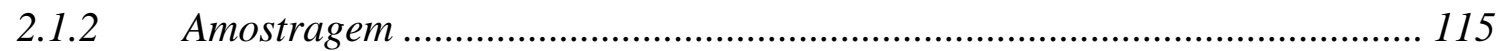

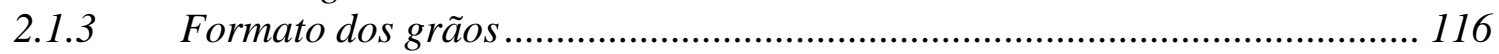

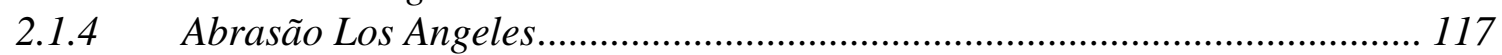

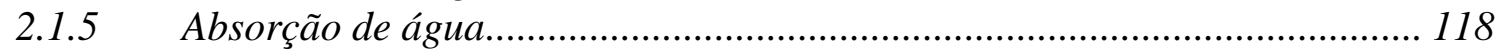

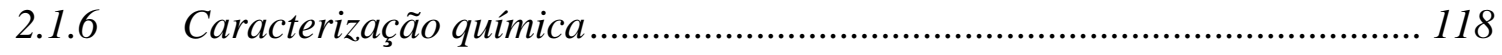

2.2. APRESENTAÇÃO E DISCUSSÃO DOS RESULTADOS 120

2.2.1 Distribuição granulométrica...................................................................... 120

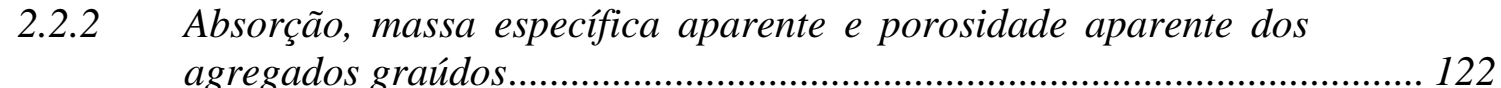

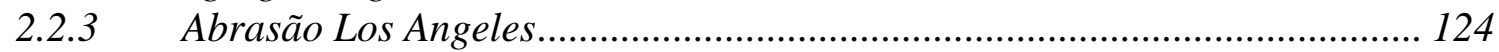

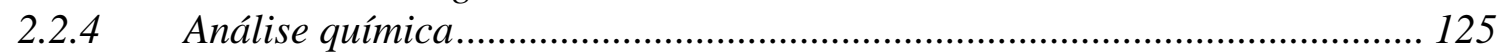

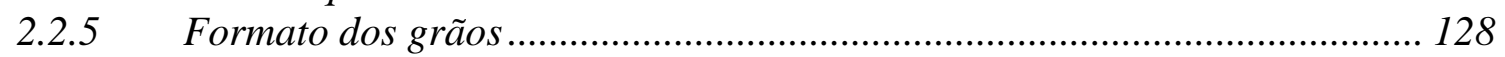

3. CARACTERIZAÇÃO DOS AGREGADOS RECICLADOS DESTINADOS À MOLDAGEM DOS CORPOS DE PROVA DE CONCRETO ........................................ 129

3.1. METODOLOGIA 129

3.1.1 Curvas granulométricas, massa específica, absorção de água, porosidade aparente ............................................................................. 129

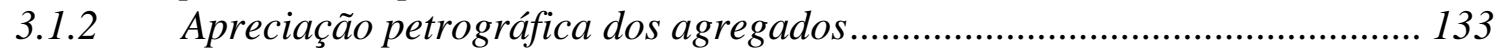

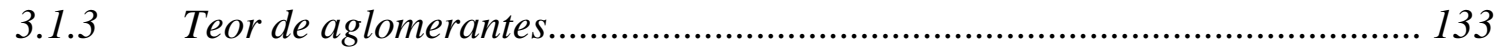

3.2. APRESENTAÇÃO E DISCUSSÃO DOS RESULTADOS 135

3.2.1 Curvas granulométricas................................................................................ 135

3.2.2 Massa específica, absorção de água, porosidade e teor de aglomerantes ............................................................................................... 137

4. CONCRETOS CONTENDO AGREGADOS RECICLADOS.................................. 139

4.1. METODOLOGIA 139

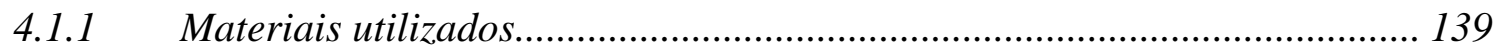

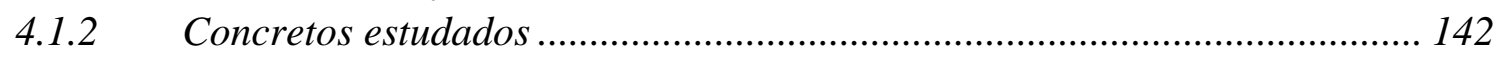




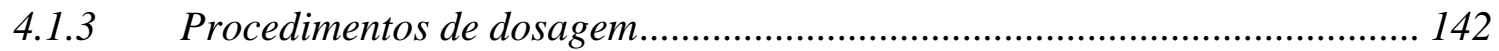

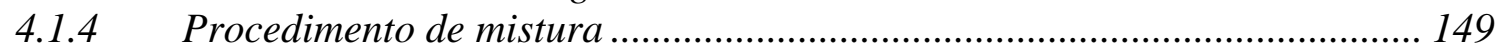

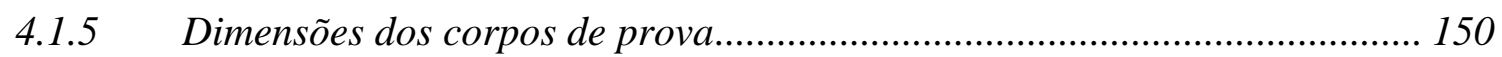

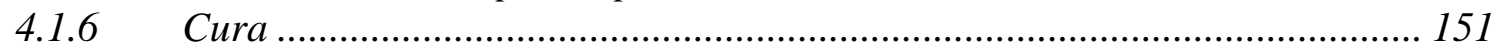

4.1.7 Propriedades do concreto no estado fresco................................................... 151

4.1.8 Propriedades do concreto no estado endurecido......................................... 152

4.2. APRESENTAÇÃO E DISCUSSÃO DOS RESULTADOS 160

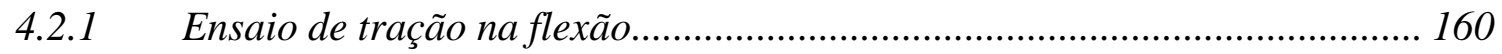

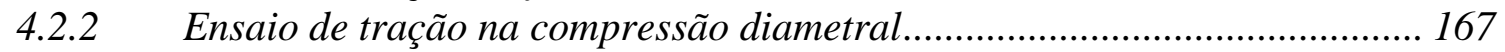

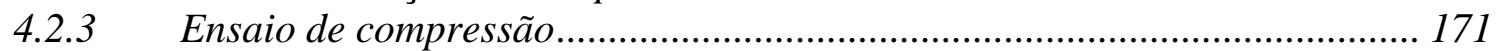

4.2.4 Módulo de elasticidade dinâmico .................................................................. 179

4.2.5 Comparação entre os valores de módulo de elasticidade obtidos por diferentes métodos .............................................................................. 181

4.2.6 Modo de ruptura do concreto ..................................................................... 182

4.2.7 Relação entre resistência à tração na flexão e resistência à

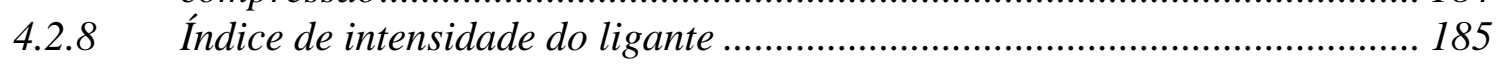



5. CONCLUSÕES E RECOMENDAÇÕES ........................................................................... 190

REFERÊNCIAS BIBLIOGRÁFICAS ................................................................................ 194

ANEXO A - CARACTERIZAÇÃO DOS AGREGADOS RECICLADOS .................. 209

ANEXO B - RESULTADOS DO ENSAIO DE DETERMINAÇÃO DO TEOR DE

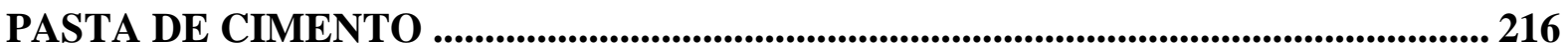

ANEXO C - EXEMPLO DE TRATAMENTO DE DADOS DOS RESULTADOS OBTIDOS NO ENSAIO DE ABSORÇÃO PROPOSTO POR DAMINELI (2007)..... 217 


\section{INTRODUÇÃO E OBJETIVOS}

O Brasil enfrenta uma crise anunciada desde o princípio da década de 80 no setor rodoviário. Esta crise possui duas componentes que paralelamente vêm se agravando década após década. De um lado, com dados do ano 2000 (GEIPOT, 2001), existe uma extensão total pavimentada de rodovias e estradas rurais de $164.988 \mathrm{~km}$ diante de uma extensão total de vias municipais, estaduais e federais de $1.724 .929 \mathrm{~km}$; ou seja, possuímos uma demanda de mais de 1,5 milhões de quilômetros de estradas carentes de pavimentação. Este apelo não é nada fácil de ser atendido, mesmo porque, do total, $1.429 .296 \mathrm{~km}$ eram estradas municipais, onde a disponibilidade de recursos frente a outras demandas sociais urgentes, para pavimentação, é muitas vezes inexistente.

O segundo aspecto é concernente à qualidade das estradas e vias pavimentadas. Em pesquisa anual da Confederação Nacional do Transporte (2007), apenas cerca de $45 \%$ da parcela de aproximadamente $50 \%$ das vias pavimentadas do país que foram objeto da avaliação, apresentavam condições de pavimentação além de favoráveis; o restante dos trechos avaliados apresentava condição de rolamento de deficiente até péssima (neste caso, atingindo cerca de $8 \%$ da malha rodoviária, que exigiria reconstrução e não simples serviços de conservação e manutenção). Não será possível superar as carências no Brasil, em matéria de infra-estrutura viária, bem como é muito difícil atender a toda a demanda existente de novas construções, sem a consideração do uso racional de materiais reciclados a partir dos próprios pavimentos já existentes.

A necessidade de reciclagem dos materiais de pavimentação é bastante conhecida por envolver primariamente problemas ambientais de exploração de novas matérias primas (com suas implicações energéticas) bem como de deposição de resíduos de demolição de pavimentos. Ou seja, além da prática de reciclagem do concreto conservar fontes naturais de agregados, ela reduz a ocupação de terras para botaforas, economiza energia e reduz a emissão de gases que provocam o efeito estufa (devido principalmente à redução em distâncias de transporte). 
O consumo de agregados naturais varia entre 1 a 8 toneladas/habitante.ano, sendo que no Brasil o consumo de agregados para produção de concreto e argamassas é de 220 milhões de toneladas por ano ${ }^{1}$. Na pavimentação rural ou urbana, para se ter uma idéia do consumo de agregados, em um quilômetro de pista simples, desconsiderados os acostamentos, pode-se consumir 5,1 vezes a quantidade de agregados consumida na construção de um edifício de 15 andares e dois subsolos, com quatro apartamentos de $80 \mathrm{~m}^{2}$ por andar (Balbo, 2007). Como pavimentos de concreto podem ser $100 \%$ recicláveis, os agregados produzidos são suficientes para substituir agregados naturais de todas as placas reconstruídas, restando material para outras aplicações (ACPA, 2009).

Segundo o United States Department of Transportation (2004) dois bilhões de toneladas de agregados são produzidas anualmente nos EUA, sendo esperado que para o ano de 2020 este número cresça em 25\%, o que obviamente causa preocupações de natureza econômica e ambiental. Globalmente, a demanda de agregados em 2008 foi de 24,9 bilhões de $\mathrm{m}^{3}$, e é esperado um aumento anual de $2,9 \%$ na demanda de agregados até o ano 2013 , alcançando 28,7 bilhões de $\mathrm{m}^{3}$ (THE FREEDONIA GROUP, 2009).

Só nos Estados Unidos a produção anual de entulho de concreto é da ordem 123 milhões de toneladas (UNITED STATES DEPARTMENT OF TRANSPORTATION, 2004), cujo emprego racional como agregado reciclado de concreto poderia mitigar, ainda que apenas parcialmente, os problemas gerados pela grande demanda de agregados. O material reciclado é ainda altamente conveniente, pois a legislação sobre bota-fora de entulho nos diversos estados americanos tem ficado mais restritiva com o passar do tempo, além de serem muito escassas áreas para tais finalidades, em especial próximo aos aglomerados humanos. Dois aspectos interessantes recordados nos estudos é que a reciclagem do concreto antigo dos pavimentos, além de evitar alterações indesejáveis do greide de rodovias e vias urbanas, reduz o impacto do transporte de materiais nas estradas por caminhões durante as fases de construção de novos pavimentos.

${ }^{1}$ disponível em http://www.reciclagem.pcc.usp.br/a construcao e.htm\#topo. Acesso em 28 abr. 2010. 
Além das questões ambientais, existem questões econômicas envolvidas. O custo dos agregados em uma obra viária (terraplanagem, fundação e camadas do pavimento) representa entre $20 \%$ e $30 \%$ do custo de materiais e suprimentos (HALM, 1980 apud ACPA, 2009). Custos de demolição e remoção do concreto estão sempre presentes, tanto quando o pavimento é descartado como quando é reutilizado; custos de produção de agregados reciclados podem ser compensados pelas economias em custos de transporte e deposição em bota-foras, que estão cada vez maiores devido à escassez e restrição de aterros.

As economias com a reciclagem de pavimentos de concreto variam com as condições de cada obra, podendo chegar a US\$5 milhões em um único projeto (CMRA, 2008), além dos ganhos ambientais. Alguns estados americanos estimaram um ganho de até $60 \%$ com o uso de agregados reciclados (ECCO, 1997).

Além disso, dados apresentados em 2002 pelo National Geographic Survey indicam que, mesmo descobertas novas jazidas de petróleo nos anos vindouros, a disponibilidade da matéria prima para a produção de asfaltos ficará seriamente agravada a partir de 2030 a 2040, com exceção ao caso do Oriente Médio cuja disponibilidade ainda superaria mais de cem anos. Dentro dessa perspectiva, o asfalto disponível na produção brasileira seria insuficiente para atender à demanda de pavimentação existente, mesmo que hipoteticamente houvesse orçamento disponível, se não fossem consideradas as novas fontes e recursos desse insumo descobertas nos anos recentes e as possíveis descobertas que surgirão futuramente.

Por todas as razões discutidas a questão da reciclagem de pavimentos é bastante emblemática nos países desenvolvidos, sendo atualmente totalmente dispensável a antiga retórica de se afirmar que após um longo tempo de serviço não se tem o que fazer, por exemplo, com as placas de pavimentos de concreto (o que configuraria uma desvantagem intrínseca de tal tipo de pavimento). Nos Estados Unidos, por exemplo, já são reciclados aproximadamente 140 milhões de toneladas de concreto por ano (CMRA, 2008). E é esperado um crescimento anual nas vendas de agregados reciclados e outros materiais secundários (tais como escória de altoforno) de 3,9\% (THE FREEDONIA GROUP, 2009). 
O uso de agregados reciclados provenientes da britagem de placas de concreto está associado a diversas aplicações na pavimentação, tais como sub-bases granulares, sub-bases estabilizadas com cimento, pavimentos asfálticos, sub-bases estabilizadas com asfalto e revestimentos em concreto. O presente trabalho é focado somente na última dessas aplicações, ou seja, a reciclagem do concreto a fim de se produzir um novo concreto.

A crescente necessidade de reutilização de recursos levou a Universidade de Washington, nos EUA, a lançar a chamada Green Road Initiative com a meta de estabelecer padrões nacionais para a construção e identificação das rodovias construídas de maneira ambientalmente sustentável (SÖDERLUND et al., 2008). Trata-se de um programa classificatório em que para ganhar status é necessário que o uso dos agregados reciclados seja feito para a construção de nova mistura asfáltica ou de concreto, não recebendo pontuação o caso de usos desses materiais reciclados como camadas de bases e de sub-bases de novos pavimentos (Vancura et al., 2009).

A agência de proteção ambiental americana (EPA - Environmental Protection Agency) identificou o crescimento da prática da reciclagem e beneficiamento de produtos industriais como uma das quatro prioridades nacionais do desafio de conservação de recursos, direcionando esforços para reduzir o efeito estufa e conservar recursos naturais, objetivos estes satisfeitos com a diretiva de reciclar 0 concreto (EPA, 2009)

Os pavimentos de concreto na Europa tiveram sua construção e uso iniciado há mais de um século, sendo que durante os anos 1930 e 1939 tiveram expressiva progressão na Alemanha e na Suíça, seguido nos anos de 1945 a 1965 na Áustria, Holanda, Bélgica e Suécia (BALBO, 2009). Após mais de 50 anos de serviço, muitos desses pavimentos, que já apresentavam defeitos e características funcionais prejudiciais, bem como defeitos estruturais insanáveis, a princípio, em finais dos anos 1980, representavam um problema: o que fazer com esses materiais, essas placas de concreto, caso removidos de pista? 
Este é o caso de muitos pavimentos de concreto existentes, como por exemplo, na via Dutra (no trecho entre km 0 e 60, no Estado do Rio de Janeiro), de inúmeros pavimentos urbanos em Recife construídos nos anos 1960 e 1970 (muitas placas estão sendo recentemente demolidas e reconstruídas pela prefeitura local) e será o caso de pavimentos como da Rodovia dos Imigrantes, trecho original de 1974, que com mais de 30 anos de serviço apresentarão, daqui cerca de dez anos, problemas de remoção (como parcialmente já vêm apresentando). Ainda neste último caso, no período 2003-2004, após a concessão da operação da rodovia à iniciativa privada, foram removidos $6 \%$ de cerca de 11 mil placas existentes gerando um volume de $2.614 \mathrm{~m}^{3}$ de pavimento demolido (6.274 t, transportadas por aproximadamente 550 caminhões para bota-fora). Porto Alegre e Pelotas no Rio Grande do Sul também são cidades que, dada a quantidade implantada de pavimentos de concreto desde a década de 1950, apresentam grande potencial para a reciclagem das placas de concreto nas reconstruções de pavimentos urbanos de concreto. Mencione-se ainda o caso da rodovia BR-101/NE, em fase de duplicação, que infelizmente não contemplou a reciclagem de centenas de quilômetros de pavimentos de concreto construídos há mais de 30 anos e que atualmente exigem reconstrução.

Agregados reciclados provenientes de pavimentos de concreto antigos possuem excelente qualidade, pois são livres de materiais contaminantes tais como cerâmica, madeira e gesso, que são comuns ao se reciclar material proveniente de resíduos de construção e demolição (RCD) em geral. Entretanto, deve-se atentar para a presença de selantes de junta, concreto asfáltico presente nos acostamentos ou em remendos, armaduras de reforço, barras de transferência de carga e de ligação, solos e materiais de camadas inferiores.

Além disso, deve-se ressaltar que apesar do uso de agregados graúdos reciclados já estar bem difundido e ter se mostrado perfeitamente possível, o uso de agregados miúdos reciclados ainda é controverso. Na Espanha, por exemplo, o tamanho mínimo de agregado reciclado permitido é $4 \mathrm{~mm}$, sendo somente tolerados $5 \%$ de material passante pela peneira de abertura $4 \mathrm{~mm}$.

Esta proposta de trabalho de pesquisa e de investigação aborda as técnicas de reciclagem de pavimentos de concreto antigos para a construção de novos 
pavimentos, um assunto pouco pesquisado no Brasil até mesmo pela geralmente escassa cultura de construção de pavimentos de concreto no país, se comparados aos volumes de construção existentes em outros países.

Dentro desse contexto, este projeto de pesquisa fomentado por meio de Bolsa de Mestrado da Fundação de Amparo à Pesquisa do Estado de São Paulo (FAPESP), tem os seguintes objetivos:

- Revisão e análise crítica da literatura disponível sobre o tema, em especial no que tange os casos de reconstrução de rodovias e vias urbanas, bem como pavimentos em concreto em geral, empregando sua reciclagem, consultandose bases de referências em especial na Europa e nos Estados Unidos da América.

- Avaliação do processo de dosagem, verificação da qualidade dos agregados e de impactos do material nas características mecânicas do concreto.

- Estudo laboratorial comparativo de concretos convencionais e de concretos reciclados (utilizando agregados graúdos e miúdos reciclados), com material recolhido das placas de concreto retiradas do Rodoanel Metropolitano Mário Covas em São Paulo (trecho Oeste, liberado ao tráfego em 2002), considerando-se diversos parâmetros de dosagem e ensaios de caracterização.

A apresentação da pesquisa realizada foi sistematizada nos seguintes capítulos:

1 - Revisão bibliográfica existente sobre a utilização de agregados provenientes da britagem de concretos existentes, considerando as características físicas do agregado e as características mecânicas do novo concreto;

2 - Metodologia da pesquisa empregada a fim de se atingir os objetivos propostos, apresentação dos modos de britagem utilizados e dos ensaios realizados; 
3 - Apresentação e discussão dos resultados dos ensaios de caracterização do agregado reciclado obtido através de dois métodos de britagem distintos (britador de mandíbula e britador por impacto) e dos resultados de ensaios mecânicos comparando o concreto contendo reciclados em diferentes proporções e o concreto de controle (concreto convencional). 


\section{REVISÃO BIBLIOGRÁFICA}

\subsection{RECICLAGEM DE CONCRETO NA PAVIMENTAÇÃO}

Existem vários métodos de tratamento de um pavimento de concreto antigo, com muitas fissuras, escalonamento de juntas, quebras, etc., para finalidades de sua restauração. Os processos mais comuns são, todos para a construção de bases de pavimentos novos (com nova carga de concreto ou misturas asfáltica como revestimento): a) quebra, craqueamento e assentamento das placas de concreto; b) emprego de mantas geotêxteis, malhas e compósitos como dispositivos (absorventes de tensões) anti-reflexão de trincas; c) compósitos absorventes; d) remoção e britagem de placas para uso como agregados reciclados em camadas estabilizadas com betume ou para manufatura de novos concretos. Este trabalho pretende concentrar-se apenas nesse último caso.

A Europa foi o primeiro continente a utilizar agregados reciclados, quando, após a II Guerra Mundial, a necessidade de reconstruir as cidades e depositar os resíduos deixados pela destruição levou ao emprego dessa solução (STURTEVANT, 2007).

O emprego de concreto reciclado em pavimentos ocorreu em escala de uso na Europa, em especial na Alemanha, desde o início dos anos 1980, quando teve início grande parte das reconstruções das auto-estradas construídas na década de 1930 (HALL, 2007). As principais dificuldades que levaram os alemães aos processos de reciclagem de pavimentos de concreto foram: a) a escassez de matéria prima virgem e seu custo devido às diretrizes ambientais de exploração de matérias virgens cada vez mais restritivas, b) o custo de execução de bota-fora para grandes quantidades de reconstruções (WOLF e FLEISCHER, 2007). Por outro lado, culturalmente inclusive, na Alemanha se tinha uma experiência recorrente altamente positiva sobre o emprego de rodovias em concreto - cerca de $40 \%$ das vias pavimentadas na Alemanha eram em concreto na década de 1990 (BALBO, 2009). Tratava-se de uma apologia técnica do conceito pós-guerra europeu de "fazer novo com o usado", empregando as antigas placas de concreto como jazidas de 
agregados para a confecção de novo concreto de pavimento. A utilização de agregados graúdos reciclados em camadas inferiores de pavimentos de concreto de duas camadas (revestimento em concreto de aproximadamente $26 \mathrm{~cm}$ em que os 7 $\mathrm{cm}$ superiores são construídos com agregados de melhor qualidade) é uma prática comum neste país. Os agregados miúdos obtidos podem ser utilizados em bases estabilizadas com cimento.

Nos Estados Unidos da América os agregados reciclados foram utilizados em misturas de concreto a partir da década de 40 (NHI, 1998 apud ACPA, 2009). No caso do seu uso em revestimentos de pavimento de concreto, as primeiras aplicações datam da década de 1970. Contudo, alguns casos iniciais de desempenho insatisfatório desencorajaram algumas agências rodoviárias estaduais a empregar tais técnicas, até que futuros trabalhos trouxessem melhor luz às dificuldades observadas (DARTER, 1988; SNYDER et al., 1997). Em 1987, mais de 1600 quilômetros de pistas de pavimentos de concreto de cimento Portland já haviam sido recicladas no país (ECCO, 1999).

Em 1989 a NCHRP (National Cooperative Highway Research Program) reportou os primeiros resultados de observações em campo de pavimentos rígidos de camada única contendo agregados reciclados construídos em lowa, Michigan, Minnesota e Wisconsin entre 1981 e 1986. Depois disso houve estudos feitos pela Universidade de Minnesota em 1997 e em 2006 em estradas construídas em Connecticut, Kansas, Minnesota, Wisconsin e Wyoming nos anos 1980. (YRJANSON, 1989)

O Estado da Virgínia foi mais longe, reduzindo substancialmente as taxas sobre a compra de equipamentos de reciclagem de materiais de rodovias pelas empresas interessadas em utilizar técnicas de reciclagem. As autoridades inclusive estabeleceram um protocolo sobre práticas de emprego de materiais reciclados incluindo concretos de pavimentos antigos para a construção e a manutenção de rodovias (pavimentos). No Estado de Michigan, desde os anos 1980, 26 obras de pavimentação compreendendo mais de mil quilômetros de faixas de rolamento em concreto foram executadas empregando concreto reciclado; a obra mais recente foi a reconstrução da rodovia US-41 com emprego de reciclagem (britagem) do antigo concreto in situ. Nas Figuras 1.1 a 1.4 são apresentadas imagens ilustrativas de 
área de produção de agregados reciclados de concreto empregada na restauração da rodovia I-94 nos Estado de Minnesota.

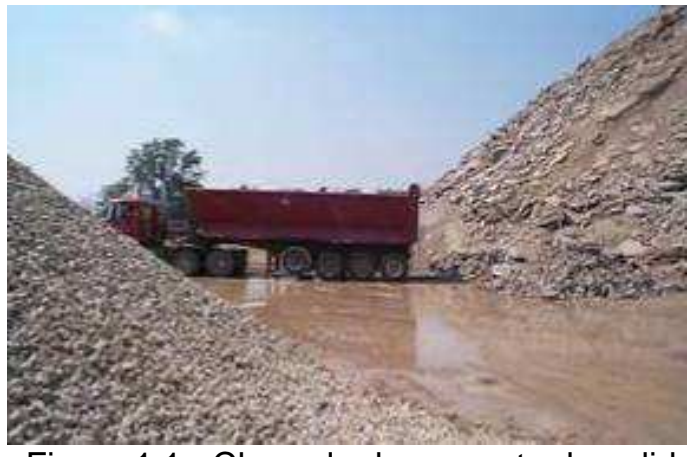

Figura 1.1 - Chegada de concreto demolido de pavimentos ao estoque

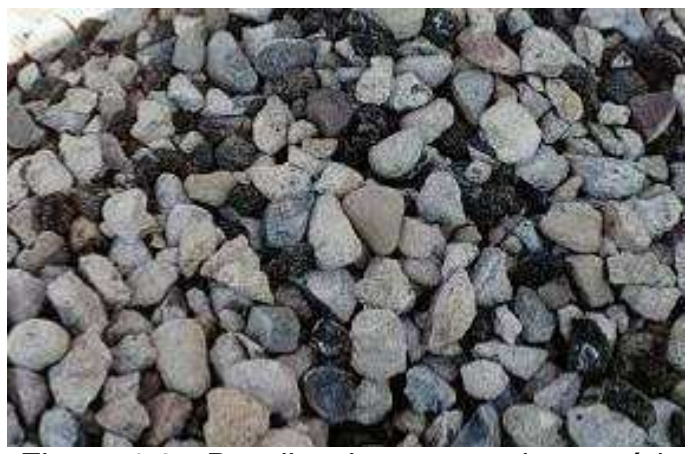

Figura 1.3 - Detalhe dos agregados graúdos após classificação

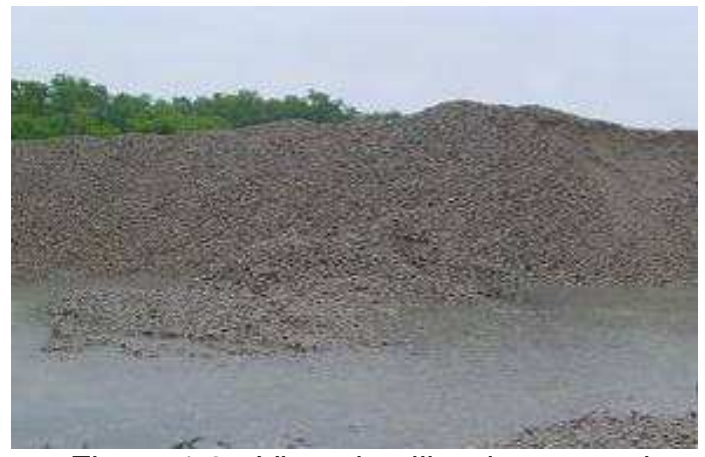

Figura 1.2 - Vista da pilha de agregados reciclados de pavimentos de concreto

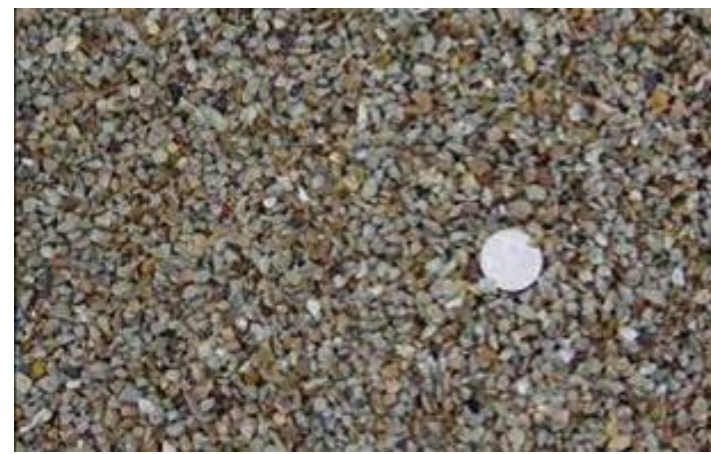

Figura 1.4 - Detalhe dos agregados miúdos após classificação

\subsection{OBTENÇÃO DE AGREGADOS RECICLADOS DE CONCRETO}

\subsubsection{Métodos de retirada de placas}

Antes de se retirar as placas de concreto, é necessário remover todo o material asfáltico da pista quando presente. A maneira mais eficiente de se fazer isso é através de fresagem a frio (Figura 1.5), embora existam outros tipos de equipamentos possíveis de serem utilizados, tais como os tratores de lâmina. Para recolher o material retirado podem ser utilizadas pás carregadeiras (Figura 1.6) ou vassouras mecânicas (ACPA, 2009). 


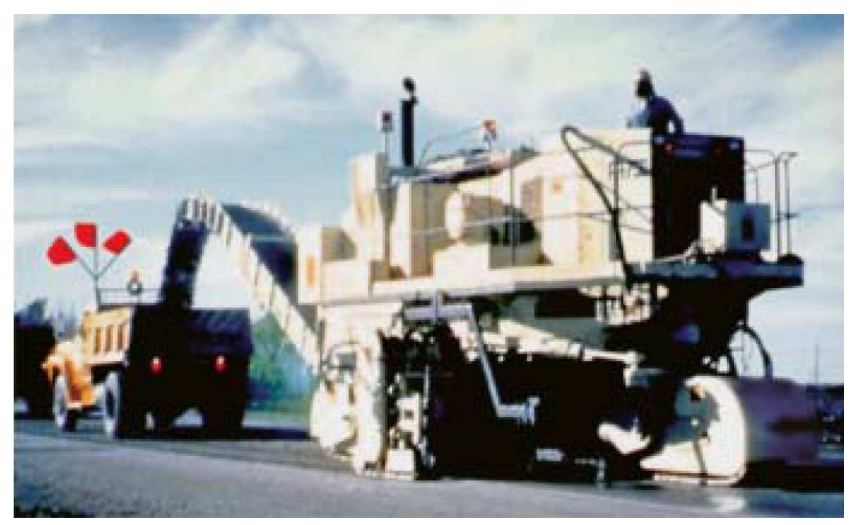

Figura 1.5 - Remoção de superfície de asfalto utilizando uma fresadora (NHI,1998 apud ACPA, 2009)

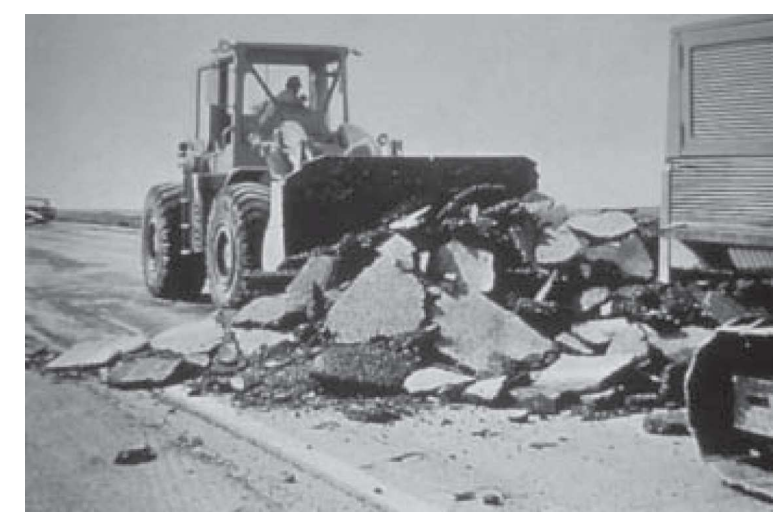

Figura 1.6 - Remoção de superfície de asfalto utilizando fresadora e pá carregadeira (NHI, 1998 apud ACPA, 2009)

Os selantes são normalmente removidos com um arado de dente cortante ou com outra ferramenta removedora de selante montada em uma pá carregadeira (ACPA, 2009).

Existem diversos métodos de retirada de placas de concreto. Quando se iniciou a prática de reciclagem de pavimentos de concreto, foram utilizados martelos, bolas de demolição e quebradores de impacto, que são utilizados até hoje. Seu mecanismo consiste na queda de uma massa pesada sobre o pavimento. São exemplos deste tipo de quebradores os martelos por gravidade (Figura 1.7); martelos hidráulicos e pneumáticos (Figura 1.8); martelos montados em trailer (Figura 1.9), que são os mais comuns; martelos de chicote; e bolas de impacto, não muito recomendadas por produzirem muitos fragmentos pequenos (ACPA, 2009). A taxa de produção dos martelos a diesel pode chegar a 900 a $1.100 \mathrm{~m}^{2} / \mathrm{h}$ para um pavimento de concreto de $200 \mathrm{~mm}$ de espessura (NHI, 1998 apud ACPA, 2009). 

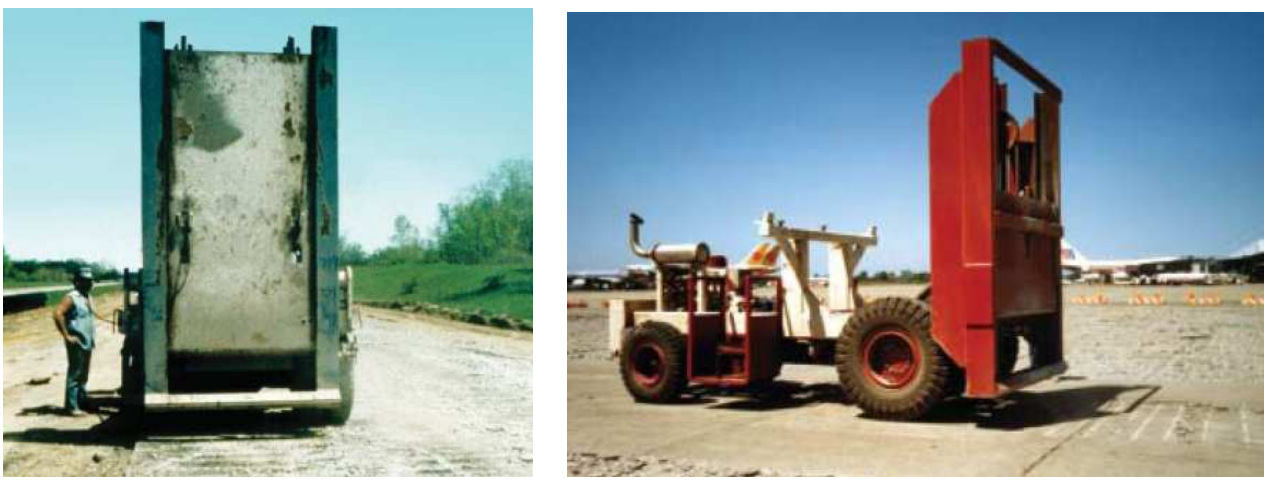

Figura 1.7 - Exemplos de equipamento de martelo por gravidade para quebra de pavimento (ACPA, 2009)

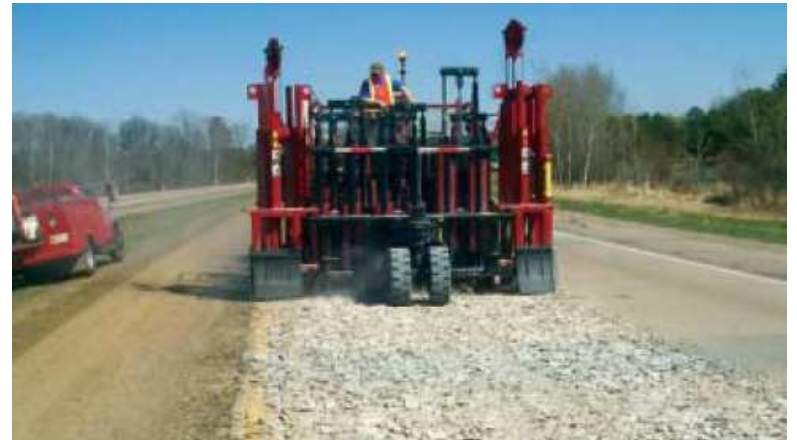

Figura 1.8 - Equipamento de martelo hidráulico multi cabeças para quebra de pavimento (ACPA, 2009)

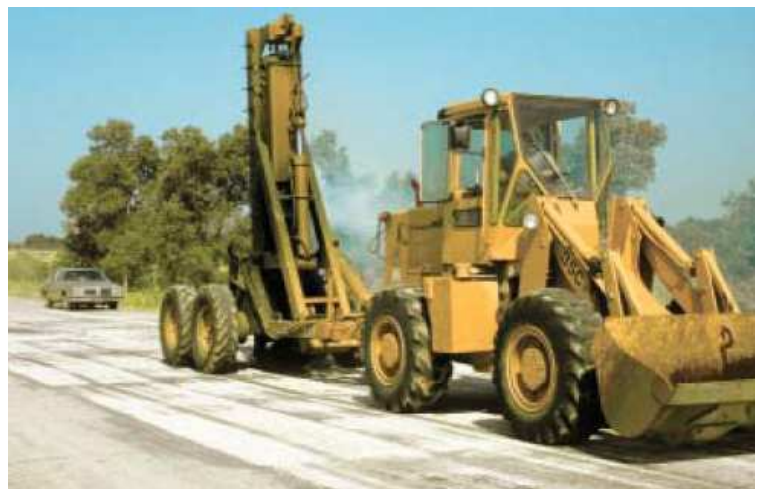

Figura 1.9 - Martelo a diesel montado em trailer (ACPA, 2009)

De uso mais recente, estão os quebradores de pavimento por ressonância, contendo uma viga vibratória acoplada a uma ferramenta parecida a uma faca que estilhaça o concreto sem transmitir as vibrações para o subleito e placas adjacentes. Esse tipo de equipamento, também chamado de quebrador por viga vibratória é o que menos danifica a base, sendo o mais recomendado quando a sub-base esta deteriorada. Além disso, é um equipamento relativamente silencioso, e, portanto, adequado para áreas urbanas. Consiste em uma grande viga metálica com uma placa quadrada (300 $\mathrm{mm}$ ) acoplada que vibra em alta frequência e baixa amplitude 
quebrando o pavimento - Figura 1.10 (HANSEN, 1992; ACPA, 2009). A taxa de produção para os quebradores por ressonância pode alcançar $670 \mathrm{~m}^{2} / \mathrm{h}$ para um pavimento de 223 mm de espessura (NHI, 1998 apud ACPA, 2009).

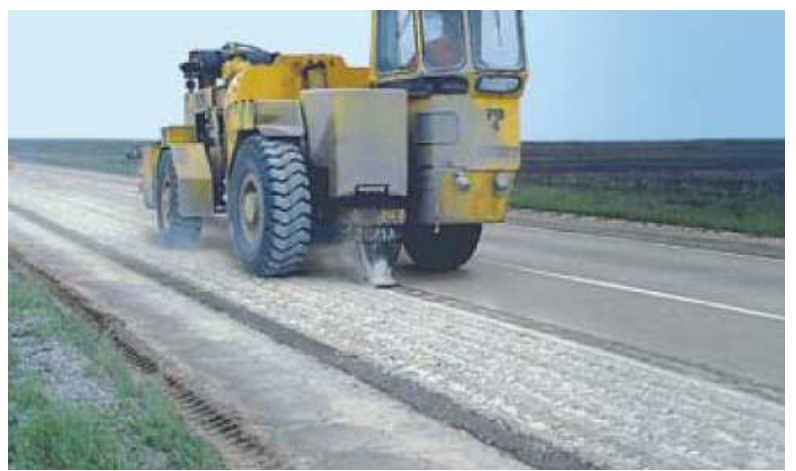

Figura 1.10 - Equipamento de viga vibratória para a quebra de pavimento (ACPA, 2009)

Normalmente as placas são quebradas em pedaços de 45 a $60 \mathrm{~cm}$. Após a quebra (Figura 1.11), é necessário soltar os pedaços de concreto e separá-los do aço. Quando o pavimento é armado, pode-se usar uma retroescavadeira ou um trator de lâmina com cortador de lança frontal (Figura 1.12). Para carregar os materiais são utilizadas pás carregadeiras e caminhões caçamba - Figura 1.13 (ACPA, 2009).

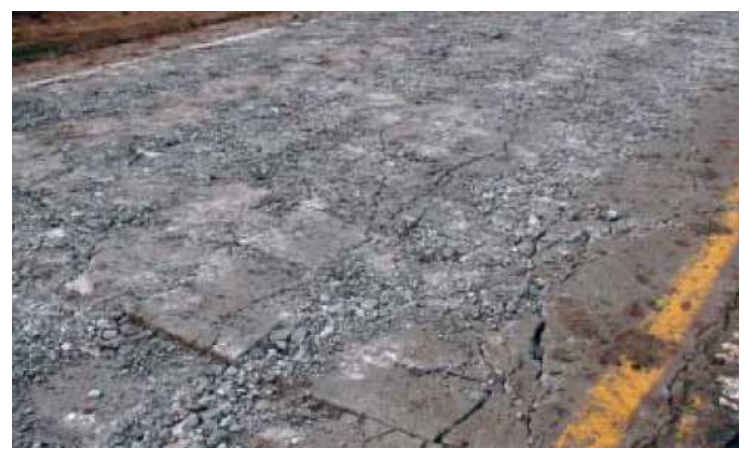

Figura 1.11 - Padrão típico da quebra de pavimentos de concreto antes da remoção (ACPA, 2009)
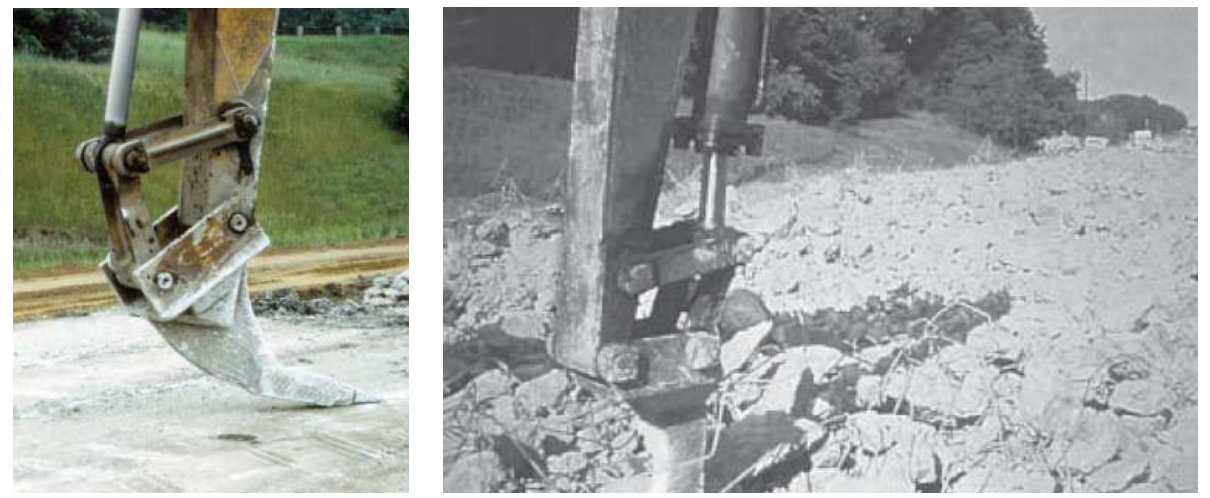

Figura 1.12 - Cortador de lança frontal utilizado para soltar os pedaços de concreto (ACPA, 2009) 


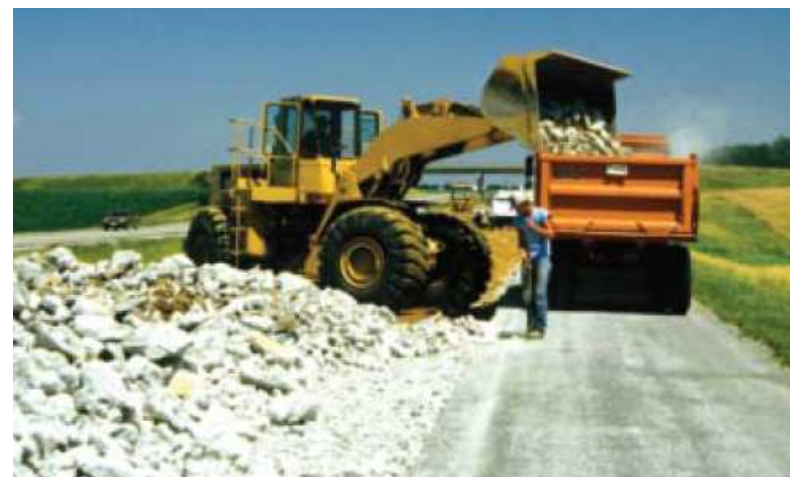

Figura 1.13 - Remoção e transporte do pavimento fragmentado com o uso de uma pá-carregadeira e um caminhão caçamba (ACPA, 2009)

A remoção de aço pode ser feita em diversas etapas do processo: durante a operação de quebra e remoção ou nas etapas de britagem primária e secundária. Podem ser utilizados eletroímãs ou catadores manuais - Figura 1.14 (ACPA, 2009).
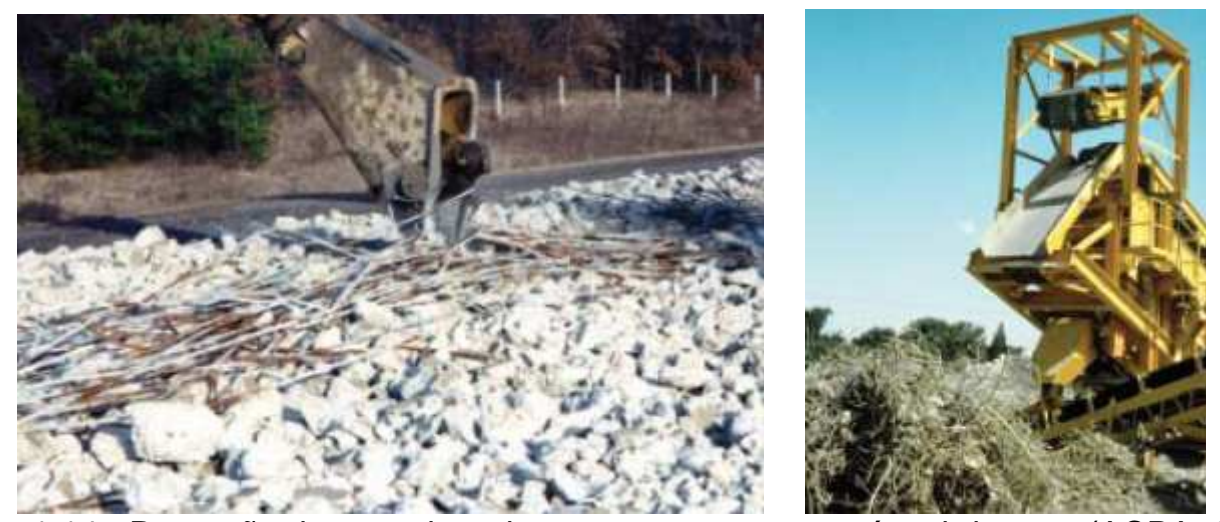

Figura 1.14 - Remoção da armadura de aço em campo ou após a britagem (ACPA, 2009)

\subsubsection{Mecanismos de britagem}

As plantas de britagem de materiais reciclados são semelhantes àquelas de produção de agregados naturais (constituídas de britadores, peneiras e transportadores de correia), com exceção da necessidade de retirada de aços por eletroímã ou catação. A etapa de cominuição do concreto corresponde a aproximadamente $70 \%$ dos custos totais de reciclagem (MOMBER, 2002).

O material pode ser transportado a uma usina de britagem para ser britado ou processado no próprio local da obra, método comumente empregado pelo fato de eliminar custos e emissões de gases no meio ambiente devido ao transporte. A realocação de usinas móveis ocorre em questão de dias. Dependendo da 
configuração dos britadores e das peneiras utilizadas é possível processar até 250 ton/h de concreto e obter até 200 ton/h de agregados reciclados de alta qualidade (FLEISCHER, 1996).

O processo de britagem pode ser feito por um ciclo fechado ou aberto. No ciclo fechado o material é peneirado depois da britagem secundária, sendo o material não passante na peneira escolhida retornado à britagem até que todo o agregado possua diâmetro máximo como especificado. O processo é economicamente otimizado quando o britador primário é regulado para reduzir o material ao máximo diâmetro que pode ir para o britador secundário sem necessidade de uma britagem terciária. No processo aberto o material não realimenta o processo, sendo o diâmetro máximo do agregado mais vagamente definido.

Os britadores utilizados são geralmente de mandíbula, de impacto, de cone (Figura 1.15), de rolo ou uma combinação destes. O diâmetro máximo do agregado reciclado e o método de britagem utilizado afetam diretamente nas quantidades de argamassa e pasta que ficam aderidas ao agregado, o que reflete nas suas características físicas e mecânicas, assim como nas do concreto produzido a partir deste. Os tipos de britadores geralmente empregados e as propriedades específicas de distintos sistemas de britagem são resumidos nas Tabelas 1.1 e 1.2.

Tabela 1.1 - Tipos de britadores empregados (adaptado de EUROPEAN DEMOLITION ASSOCIATION,1992 apud JUAN, 2004)

\begin{tabular}{|cc|}
\hline Britador primário & Britador secundário \\
\hline Britador de mandíbulas & Britador de cone \\
\hline Britador de mandíbulas & Britador de impacto \\
\hline Britador de impacto & Britador de impacto \\
\hline Britador de impacto & - \\
\hline
\end{tabular}

Tabela 1.2 - Propriedades específicas de sistemas de britagem distintos (adaptado de EUROPEAN DEMOLITION ASSOCIATION, 1992 apud JUAN, 2004)

\begin{tabular}{|lccc|}
\hline \multicolumn{1}{|c}{ Propriedade } & Britador de mandíbula & Britador de cone & Britador de impacto \\
\hline capacidade & alto & médio & baixo \\
\hline custo de produção & baixo & médio & alto \\
\hline desgaste & baixo & baixo & alto \\
\hline $\begin{array}{l}\text { qualidade do } \\
\text { agregado }\end{array}$ & baixo & médio & alto \\
\hline $\begin{array}{l}\text { conteúdo de } \\
\text { agregados miúdos }\end{array}$ & baixo & médio & alto \\
\hline consumo de energia & baixo & médio & alto \\
\hline
\end{tabular}


Britador de mandíbula

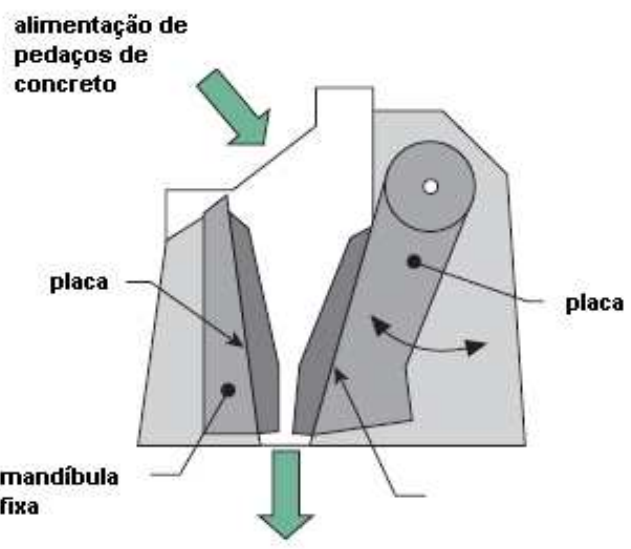

Britador de cone

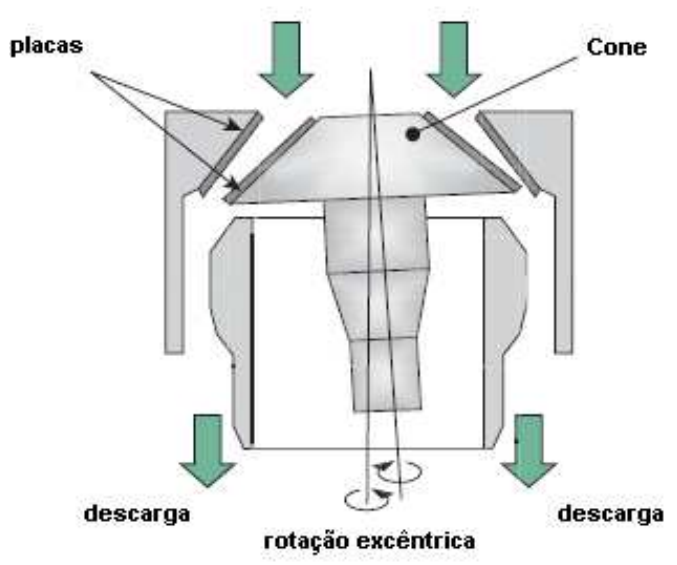

Britador de impacto de eixo vertical

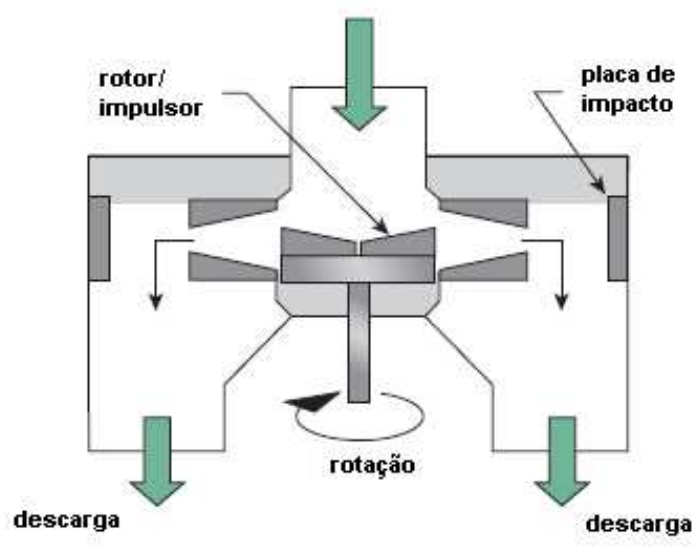

Britador de impacto de eixo horizontal

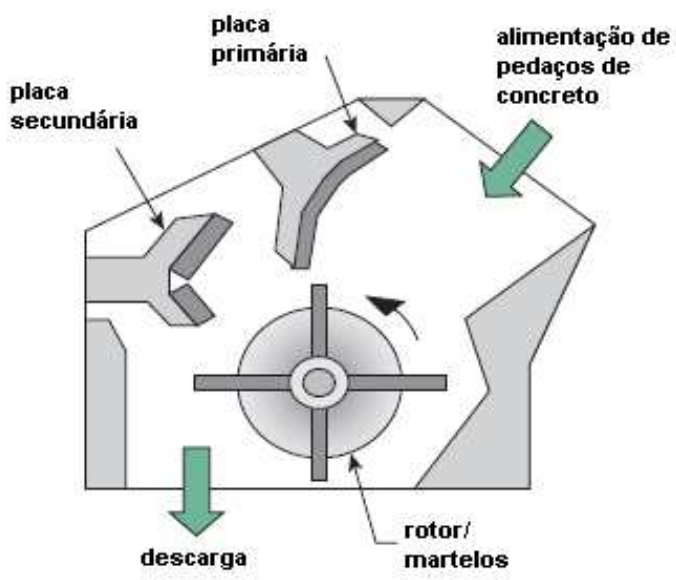

Figura 1.15 - Esquema ilustrativo de vários tipos de britadores (adaptado de ACPA, 2009)

Maiores quantidades de pasta de cimento aderida significam maior porosidade do material, levando a uma menor massa específica, maior absorção de água, menor resistência à abrasão e maior conteúdo de sulfato, características indesejáveis para o agregado. Portanto, é desejável que o método de britagem utilizado consiga remover o máximo de pasta aderida possível (STURTEVANT, 2007).

A quantidade de argamassa (cimento mais areia) aderida tende a ser maior quando o tamanho dos agregados reciclados é menor (HANSEN, 1992). Ensaios realizados por Juan e Gutiérrez (2009) mostraram que a quantidade de argamassa aderida 
para a fração de diâmetro $4 / 8 \mathrm{~mm}$ variou entre $33 \%$ e $55 \%{ }^{2}$, enquanto para a fração $16 \mathrm{~mm}$ a variação foi de $23 \%$ a $44 \%$; confirmando a tendência observada por Hansen e Narud (1983), de aproximadamente 60\% para a fração 4/8 e 30\% para a fração 16-32 mm. Quando se considera somente a pasta de cimento aderida (sem a presença da areia), encontram-se valores de desde 5,5\% a 27,4\% na literatura (JUAN, 2004).

O tamanho máximo do agregado também determina a quantidade de agregados reciclados graúdos obtidos no processo. Maiores frações do material podem ser reaproveitadas quando o tamanho dos agregados desejado é maior. Para agregados de diâmetro máximo de $28 \mathrm{~mm}$ é possível obter $80 \%$ em agregado graúdo, enquanto para um diâmetro máximo de $19 \mathrm{~mm}$ é possível recuperar somente 55 a 60\% em agregados graúdos (NHI, 1998 apud ACPA, 2009). Todavia, essas porcentagens podem variar. No caso encontrado por Yrjanson (1989), para diâmetro máximo de $38 \mathrm{~mm}$ foi obtido aproximadamente $65 \%$ de agregados graúdos e 35\% de miúdos. E no caso relatado por Eickschen e Siebel (1998), para diâmetro máximo de $32 \mathrm{~mm}$, a quantidade de areia produzida é de aproximadamente 30 a $40 \%$ do total de agregados.

\subsubsection{Vantagens e desvantagens de cada tipo de britador}

Segundo Cur (1984) apud Hansen (1992), britadores de mandíbula quebram somente uma pequena fração dos agregados naturais presentes no concreto; enquanto britadores de impacto quebram igualmente partículas de argamassa aderida e de agregados graúdos naturais, produzindo agregados reciclados de qualidade inferior.

\footnotetext{
${ }^{2}$ Medida feita a partir tratamento térmico, em que o material passa por diversos ciclos de molhagem e secagem. A exposição ao calor quando o material está saturado provoca uma secagem brusca, que causa tensões e fissuras na pasta aderida, fazendo com que esta seja facilmente removida. Após a remoção da pasta a amostra passa pela peneira $4 \mathrm{~mm}$, obtendo-se o agregado graúdo (que é retido). A quantidade de pasta aderida é dada por:
}

$$
\frac{m_{i}-m_{f}}{m_{i}} \times 100
$$


Contudo, segundo diversos outros pesquisadores, britadores de impacto são mais eficientes na produção de agregados reciclados com menos quantidade de pasta aderida. Afirma-se que os britadores de mandíbula, ao comprimir os agregados, provocam fissuras prejudiciais à resistência ao gelo/degelo; enquanto o britador de impacto quebra o material no ponto mais fraco, levando a uma melhor qualidade do agregado (melhor resistência, melhor comportamento quando submetido ao gelo/degelo, forma do grão mais favorável) (FLEISCHER, 1996; TFB, 2000; ETXEBERRIA et al., 2007; ACPA, 2009).

Chaves (1999) explica que em britadores de mandíbula a quebra das partículas se dá por forças de compressão que induzem tensões de cisalhamento, enquanto no britador de impacto a quebra se dá em alta velocidade, sendo a energia cinética transformada em fratura. Devido à quebra ao longo das fraquezas, o britador de impacto acredita-se que o britador de impacto seja mais eficiente na liberação entre a pasta de cimento porosa e as rochas naturais presentes nos agregados reciclados. Porém, existe um inconveniente no uso de britadores de impacto: o maior desgaste que sofrem acarreta maiores custos de manutenção.

Britadores cônicos também são mais eficientes que os de mandíbula na retirada da pasta aderida, entretanto, somente admitem partículas de aproximadamente 200 $\mathrm{mm}$, sendo portanto, mais apropriados para a britagem secundária (JUAN, 2004; GRESS et al., 2009).

\subsubsection{Britagem secundária}

Li et al. (2008), em suas pesquisas com agregados reciclados de concreto, realizaram britagem primária com britador de mandíbula e britagem secundária com britador de impacto, concluindo que esta segunda etapa é importante para melhorar o formato dos agregados reciclados, diminuindo a quantidade de agregados pontiagudos (britadores de mandíbulas produzem partículas mais angulosas). Obtiveram, com as duas etapas de britagem, partículas de diâmetro entre 5 e 31,5 $\mathrm{mm}$, massa específica aparente de $2,497 \mathrm{~g} / \mathrm{cm}^{3}$, absorção de água de 4,6\%, valor de britagem de $23 \%$, índice de abrasão Los Angeles de $20 \%$ e conteúdo pontiagudo de 1,8\%; enquanto que somente com a britagem por mandíbulas obtiveram massa 
específica aparente de $2,435 \mathrm{~g} / \mathrm{cm}^{3}$, absorção de água de $8,7 \%$, valor de britagem de $27 \%$, índice de abrasão Los Angeles de 24,2\% e conteúdo pontiagudo de 8,4\%.

Chini e Kuo (1998) apud IPRF (2006) também afirmam que o uso de um britador de mandíbula seguido de um britador rotativo produz agregados reciclados com os melhores formatos. Quanto maior a quantidade de processos de britagem a que o material for submetido, menor será a quantidade de pasta aderida. Contudo, o número de processos é limitado pelo custo de produção, sendo necessário encontrar um balanço entre a quantidade de processos de britagem e a qualidade requerida para o agregado de acordo com sua aplicação (JUAN, 2004).

Nagataki et al. (2004) salientam que a quantidade de pasta aderida não é o único fator determinante da qualidade do agregado graúdo reciclado, devendo-se ressaltar as mudanças microestruturais que o processo de britagem acarreta. Em seu estudo foi observado que, quando utilizados agregados originais de calcário, a britagem com britador de mandíbula e de impacto reduz significantemente as fissuras dos agregados originais, eliminando vazios e irregularidades. Isso ocorreu porque a maior concentração de fissuras no concreto original se encontrava nos agregados graúdos de calcário, sendo essas as zonas fracas que são separadas no processo de britagem. Ao se prosseguir o processamento do material com um triturador mecânico, ocorre a reintrodução de fissuras; entretanto a qualidade do agregado reciclado melhora, pois o efeito da presença de fissuras é compensada por uma menor quantidade de pasta aderida. Ou seja, após todos esses níveis de processamento sugeridos, o agregado reciclado gerado possui um comportamento estável da pasta que restou aderida e uma boa ligação na zona interfacial, pois as zonas mais fracas foram eliminadas.

Os mesmos autores observaram que ao se britar o material com britadores de mandíbula e impacto, a taxa de recuperação de agregados graúdos reciclados era de $60 \%$, ou seja, que a cada 1 tonelada de concreto conseguia-se $400 \mathrm{~kg}$ de agregados miúdos. Ao se continuar o processamento do material através de um triturador mecânico a fim de minimizar o teor de pasta aderida, a taxa de recuperação se reduzia a 35\%. Os níveis de processamento e as respectivas taxas de recuperação encontradas são ilustrados nas Figuras 1.16 e 1.17. 


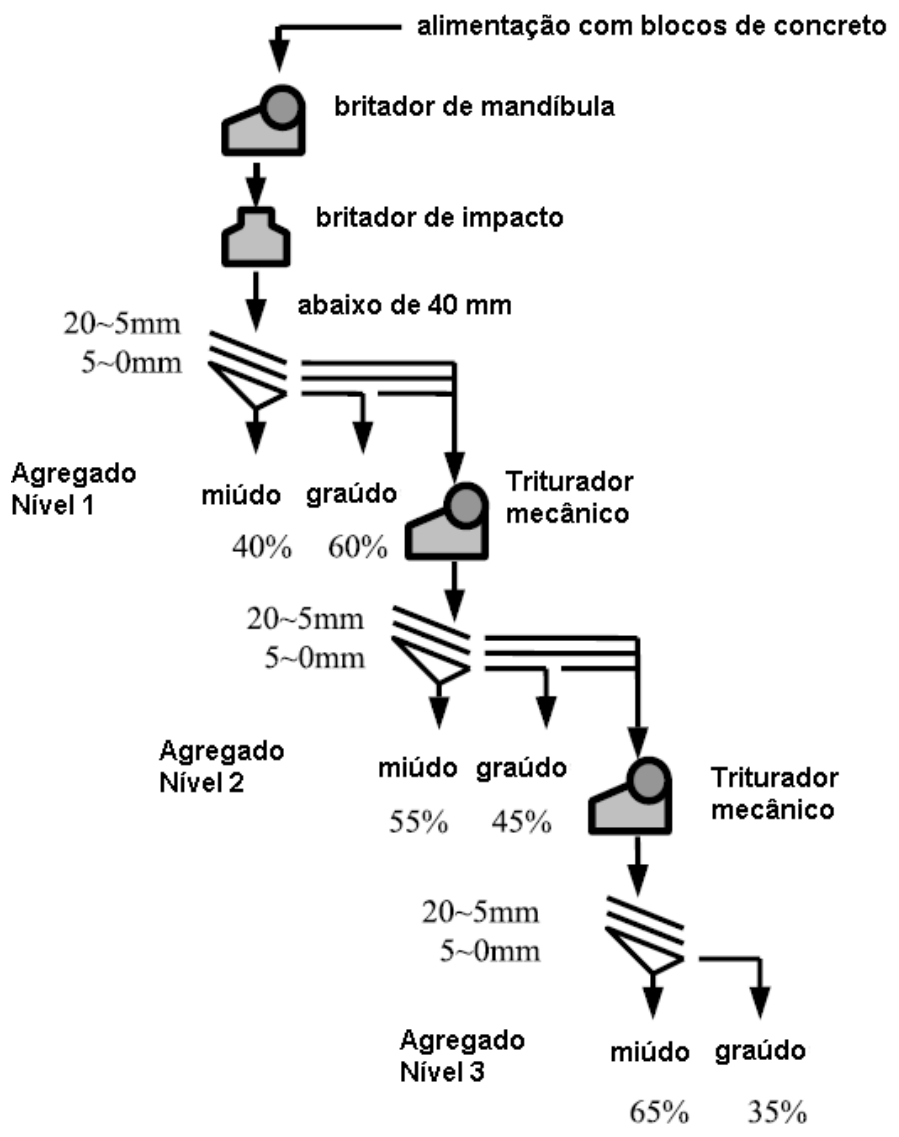

Figura 1.16 - Esquema do processo de reciclagem utilizado por Nagataki et al. (adaptado de NAGATAKI et al., 2004)

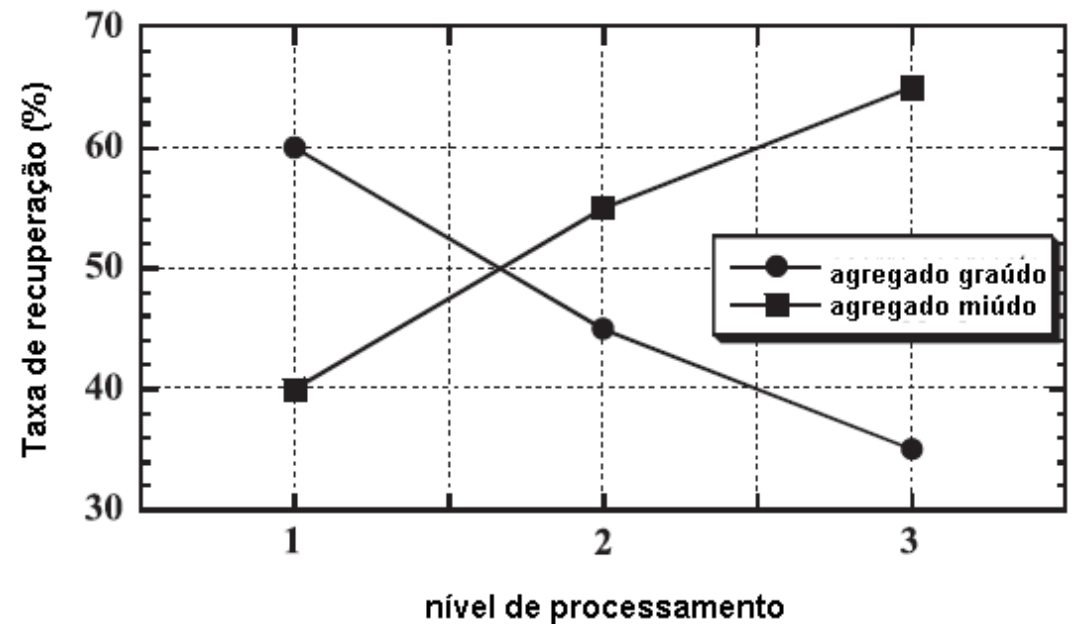

Figura 1.17 - Variação da taxa de recuperação com o nível de processamento (adaptado de NAGATAKI et al., 2004)

\subsubsection{Novas tecnologias de britagem}

Existe ainda outro método de reciclagem dos agregados, proposto por Shima et al. (2005), através de um processo chamado HRM (heating and rubbing method - 
método de aquecimento e friç̧ão). O método consiste em se aquecer os agregados em um forno a $300^{\circ} \mathrm{C}$ e esfregá-los em um moedor a fim de remover a pasta aderida. Os agregados miúdos gerados a partir da pasta de cimento podem ser utilizados como matéria prima para cimento, aditivos ou estabilizador de solo. $\mathrm{O}$ ciclo do concreto, com a implantação desse método, seria esquematizado conforme a Figura 1.18

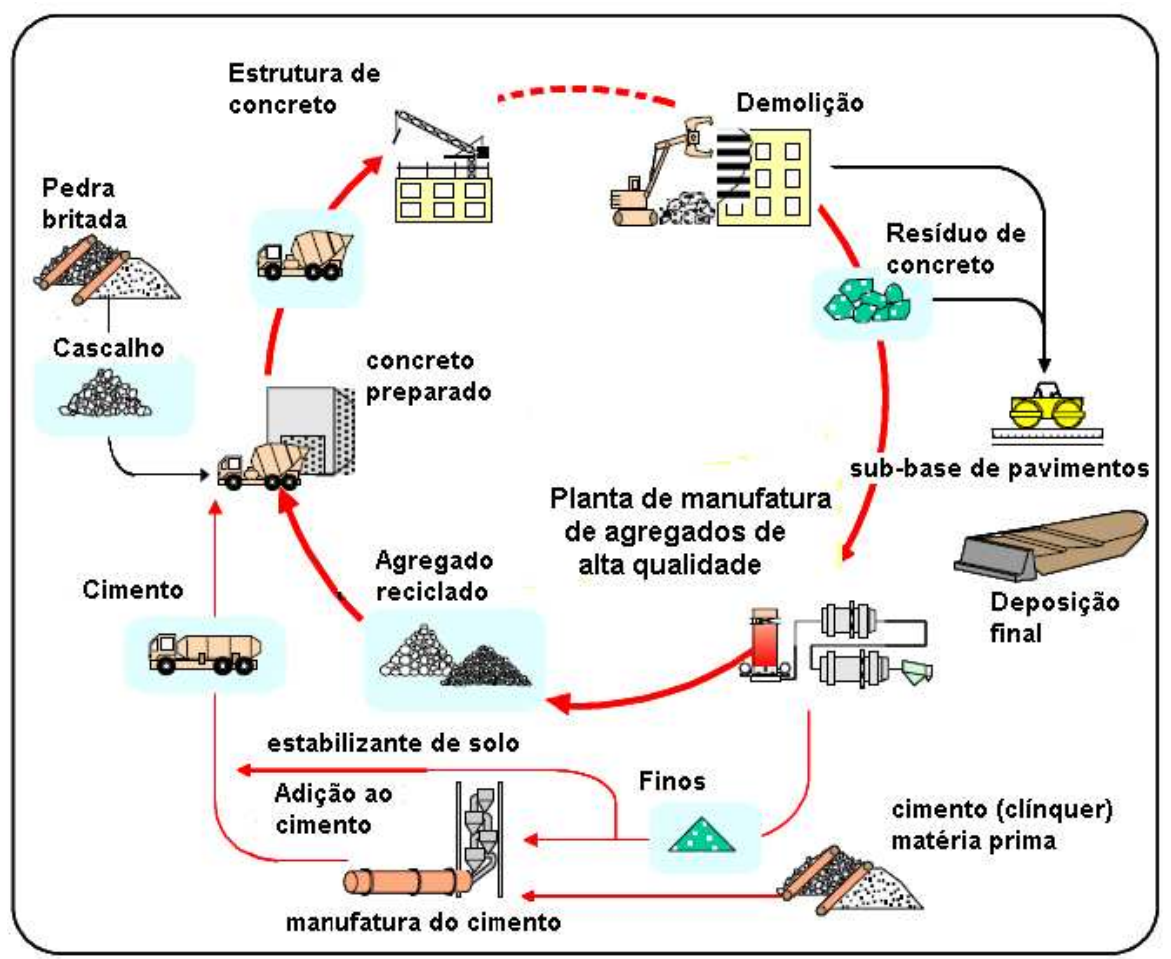

Figura 1.18 - Fluxo esquemático do sistema de reciclagem de concreto com a implantação do método HRM (adaptado de SHIMA et al., 2005)

Existem também diversos processos de separação do material por massa específica a fim de separar materiais de melhor qualidade - mais densos e com maior presença mineral - dos de qualidade inferior - menos densos e com maior quantidade de pasta aderida (CARRIJO, 2005). Essas operações podem encarecer o processo de reciclagem, e no caso de pavimentos de concreto geralmente não são realizadas, já que o material é bastante homogêneo e possui alta massa específica. 


\subsection{PROPRIEDADES DOS AGREGADOS RECICLADOS}

\subsubsection{Composição}

As características dos agregados reciclados não são as mesmas dos naturais, já que os primeiros possuem, além dos agregados naturais originais, uma camada de argamassa ou pasta de cimento aderida à superfície (Figura 1.19).

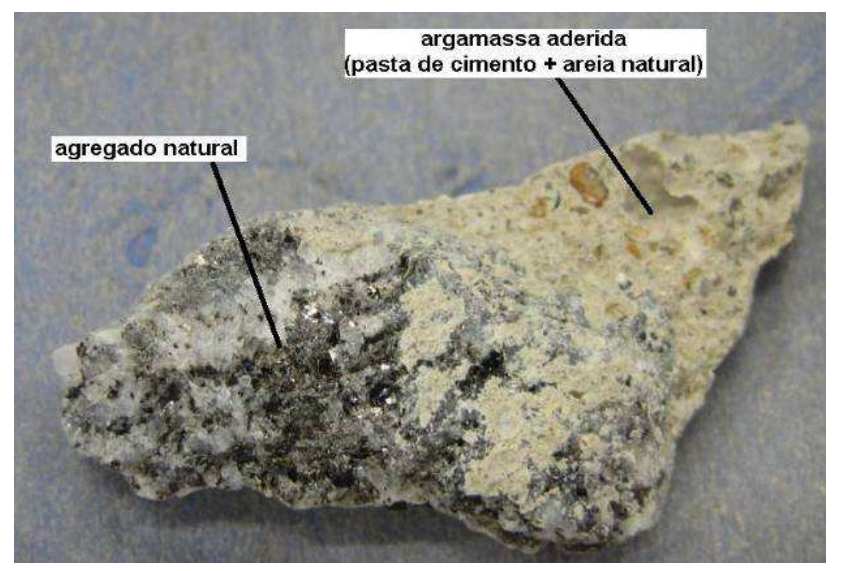

Figura 1.19 - Agregado reciclado de concreto

A Tabela 1.3 apresenta uma comparação entre as propriedades típicas dos agregados.

Tabela 1.3 - Comparação típica entre agregados naturais e agregados reciclados de concreto (adaptado de ANDERSON et al., 2009)

\begin{tabular}{lcc}
\hline Propriedade & Agregado virgem & $\begin{array}{c}\text { Agregado reciclado de } \\
\text { concreto }\end{array}$ \\
\hline Forma e textura & $\begin{array}{c}\text { bem redondo, liso (cascalho) a } \\
\text { angular e rugoso (pedra } \\
\text { britada) }\end{array}$ & $\begin{array}{c}\text { angular com superfície } \\
\text { rugosa }\end{array}$ \\
\hline Absorção de água & $0,8-3,7 \%$ & $3,7-8,7 \%$ \\
\hline $\begin{array}{l}\text { Massa específica } \\
\text { aparente }\end{array}$ & $2,4-2,9$ & $2,1-2,4$ \\
\hline $\begin{array}{l}\text { Perda de massa em } \\
\text { ensaio de abrasão L.A. }\end{array}$ & $15-30 \%$ & $20-45 \%$ \\
\hline $\begin{array}{l}\text { Perda de massa em } \\
\text { sulfato de sódio }\end{array}$ & $7-21 \%$ & $18-59 \%$ \\
\hline $\begin{array}{l}\text { Perda de massa em } \\
\text { sulfato de magnésio }\end{array}$ & $4-7 \%$ & $1-9 \%$ \\
\hline \begin{tabular}{l} 
Teor de cloreto \\
\hline
\end{tabular}
\end{tabular}


No que diz respeito aos agregados reciclados para uso em pavimentação, recomenda-se que pelo menos $90 \%$ do material sejam compostos de pasta de cimento e agregado natural (FHWA, 2007 apud ACPA, 2009). Alguns limites máximos de teor de contaminantes, sugeridos pela ACPA (2009), são:

- asfalto - $1 \%$ em volume;

- gesso - 0,5\% em peso;

- substâncias orgânicas - 0,15\% em peso;

- vidro - não permitido devido à possibilidade de causar reação álcali-sílica ${ }^{3}$;

- solo - de acordo com a ASTM.

Segundo a NHI (1998) apud ACPA (2009) pequenas quantidades de selante de juntas, óleo de motor e outros contaminantes superficiais comuns em pavimentos não têm apresentado maiores problemas na reciclagem de pavimentos de concreto.

\subsubsection{Porosidade}

Haja vista a maior porosidade da pasta de cimento em relação àquela de agregados naturais, a porosidade dos agregados reciclados é maior se comparada aos agregados naturais, já que possui em sua composição quantidade considerável de pasta de cimento aderida.

\subsubsection{Absorção de água}

Valores de absorção de água em agregados reciclados são consideravelmente mais elevados se comparados aos agregados naturais, devido à maior porosidade da antiga pasta de cimento presente. A absorção de água apresentada pelos agregados naturais é próxima de $0 \%$, enquanto aquela apresentada por argamassas é de aproximadamente 16 a 17\%. Maiores quantidades de pasta aderida significam, portanto, maior absorção de água por parte dos agregados reciclados (YANG et al., 2008).

\footnotetext{
${ }^{3}$ Deve-se ressaltar que, apesar da recomendação dada pela ACPA (2009), seria possível mitigar a reação álcali-sílica com o uso de materiais pozolânicos e de escória de alto-forno, além de emprego de produtos feitos à base de lítio.
} 
Poon et al. (2004b) encontraram valores de absorção de água de 5-15\% em agregados reciclados, enquanto agregados naturais apresentavam absorção de apenas 1\%. Etxeberria et al. (2007) encontraram valores próximos a estes, 4,5\% para os agregados graúdos reciclados, com massa específica aparente de 2,67 $\mathrm{kg} / \mathrm{m}^{3}$, e $0,9 \%$ para os naturais, com massa específica aparente de $2,43 \mathrm{~kg} / \mathrm{m}^{3}$. Cervantes et al. (2007) encontraram valores de absorção 2,5 vezes maiores nos agregados reciclados, relatando valores de 5,27\% nos reciclados e $2,01 \%$ nos naturais. E Ricci (2007), para agregado reciclado proveniente de placas de concreto do revestimento de pavimento de um corredor de trólebus, encontrou valores entre $4,60 \%$ e $5,90 \%$.

A absorção de água e a massa específica aparente do agregado são inversamente proporcionais, porque à medida que a absorção aumenta, o volume é maior porque inclui os poros dos agregados, levando a menores massas específicas.

Agregados miúdos reciclados possuem a tendência de apresentar valores ainda mais elevados de absorção, já que em sua constituição possuem maior quantidade de pasta de cimento. Hendricks (1994) apud Vancura et al. (2009) relatam valores de 6\% a 12\%; e Eickschen e Siebel (1998), de 7 a 9\%. Esses últimos autores afirmam que geralmente quanto menor a partícula de agregado reciclado, maior será a absorção de água, fato que é comprovado pelos resultados que obtiveram em seu estudo (Figura 1.20). 


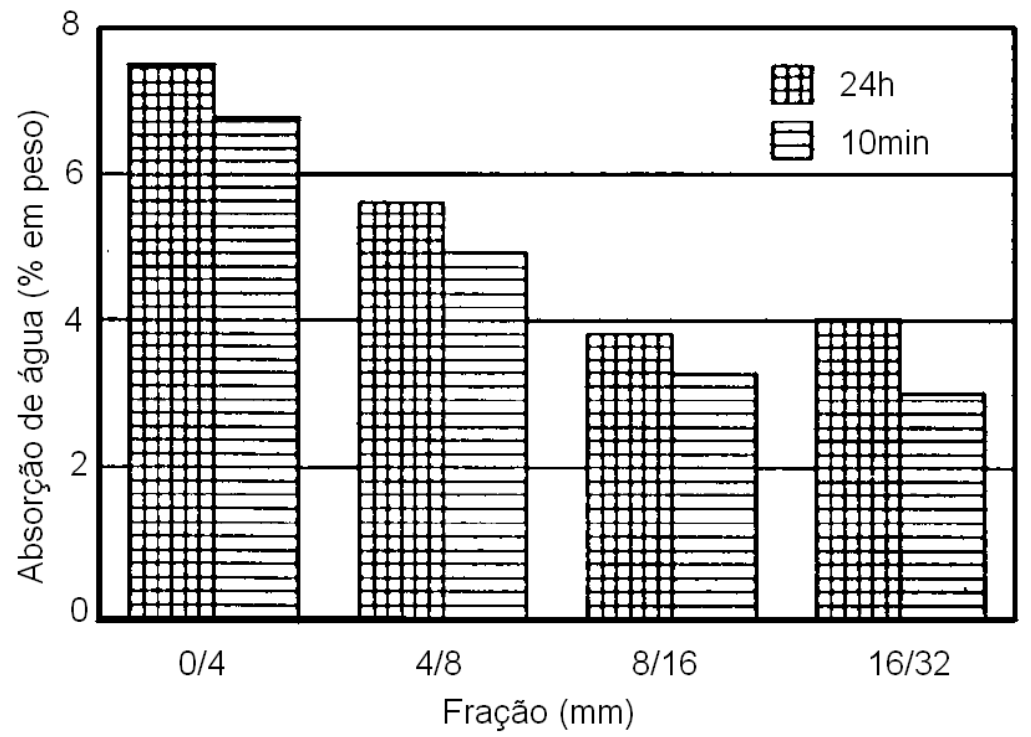

Figura 1.20 - Absorção de água de agregados reciclados em função do tamanho e do tempo (adaptado de EICKSCHEN e SIEBEL, 1998)

Além disso, a Figura 1.20 permite observar que em 10 minutos a quantidade de água absorvida pelos agregados já é de aproximadamente $70 \%$ a $90 \%$ da absorção total em 24 horas. Outros estudos com agregados provenientes de RCD confirmam que a absorção de água de agregados reciclados em 10 minutos é de aproximadamente $80 \%$ a 90\% da absorção em 24 horas (RUHL, 1992; ANGULO, 2005; NEALEN e SCHENK, 2008).

Outro fator que influi na absorção dos agregados reciclados é o tamanho dos poros nele contidos, mais especificamente, contidos na pasta aderida a estes, o que também depende do concreto originário. Poon et al. (2004) encontraram nos agregados reciclados provenientes de concretos convencionais, poros com tamanhos distribuídos entre 0,01 a $1 \mu \mathrm{m}$, enquanto nos agregados reciclados provenientes de concreto de alto desempenho os poros são, na sua maioria, menores que $0,1 \mu \mathrm{m}$. Realizando o ensaio de intrusão de mercúrio, o autor obteve para os agregados naturais o valor de 1,60\%; para o reciclado proveniente de concreto convencional, $16,81 \%$, e para o agregado reciclado proveniente de CAD, $7,86 \%$, comprovando que o uso de CAD como material para produção de reciclados gera agregados de menores valores de absorção de água. As Figuras 1.21 e 1.22 ilustram a curva de distribuição de poros cumulativa e a curva de distribuição de tamanho dos poros diferencial nos agregados utilizados pelos autores. 


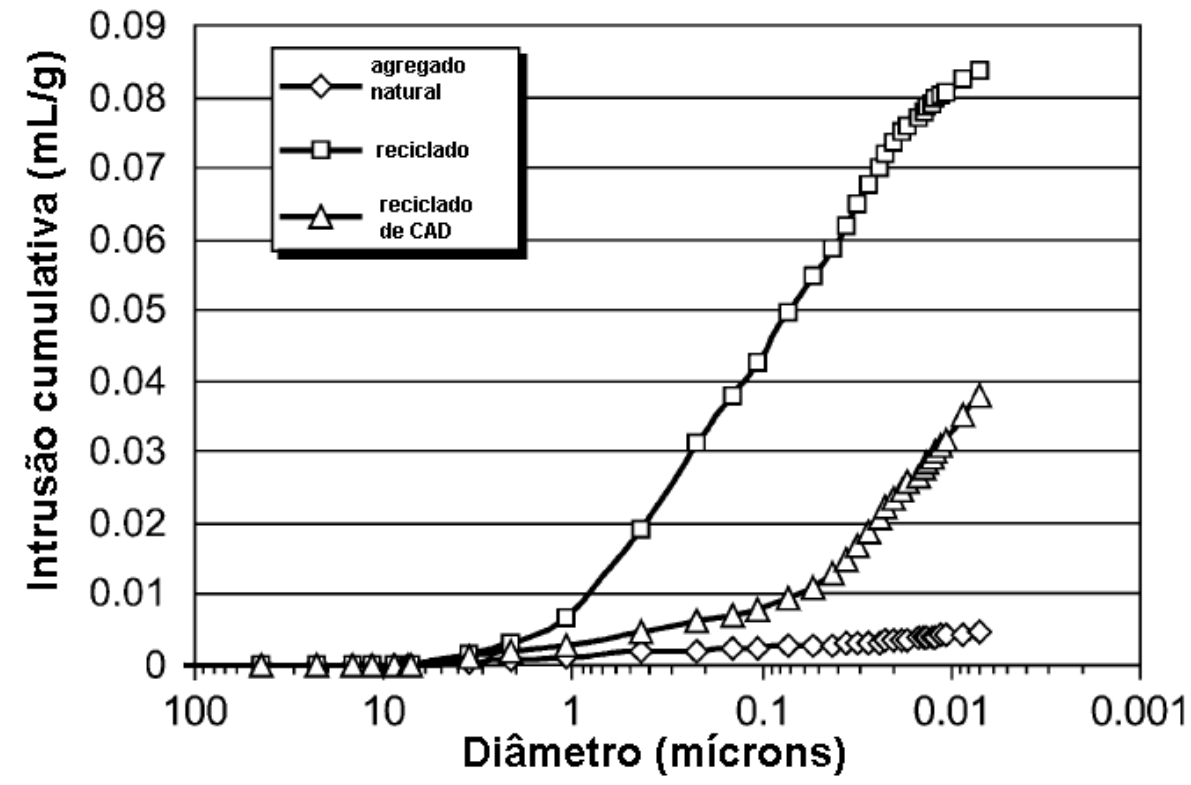

Figura 1.21 - Curvas de distribuição de poros cumulativa de agregados naturais e reciclados (adaptado de Poon et al., 2004b)

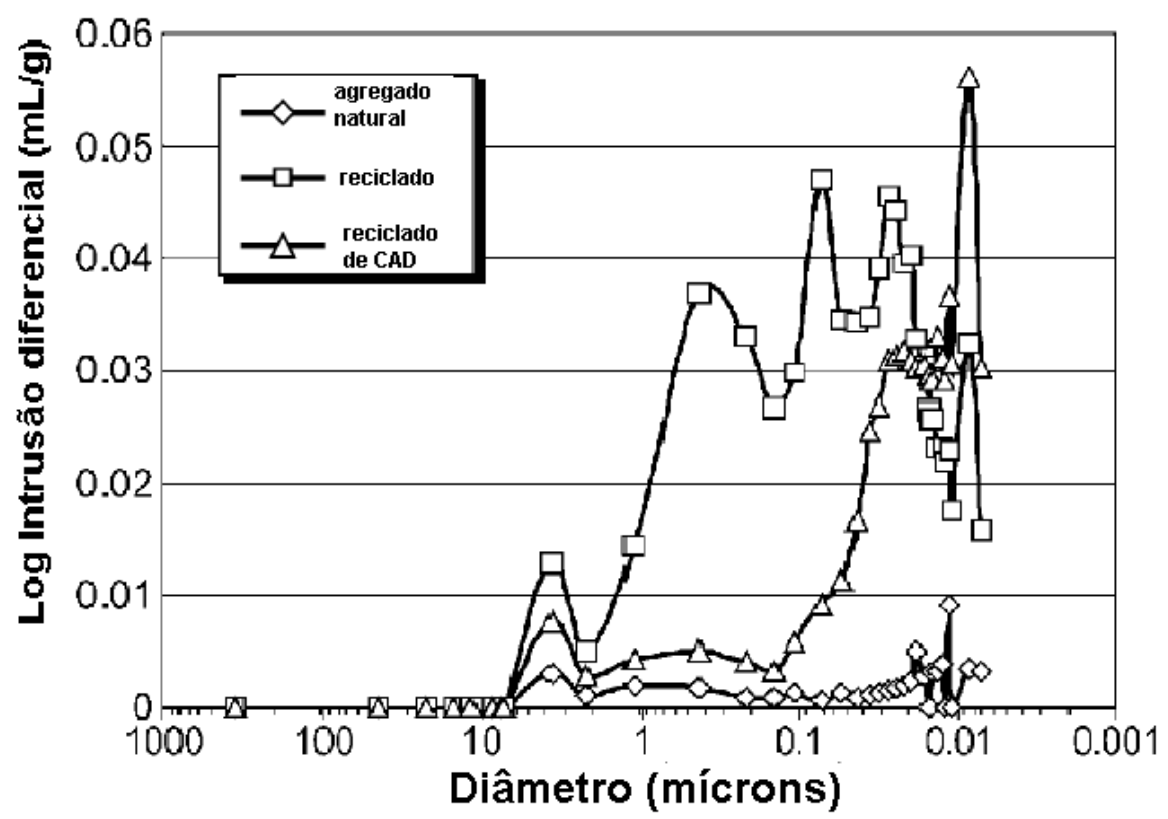

Figura 1.22 - Curvas de distribuição de tamanho de poros diferencial dos agregados naturais e reciclados (adaptado de Poon et al., 2004b)

Bairagi et al. (1993) observaram que nos primeiros 30 minutos os agregados reciclados absorvem cerca de $76 \%$ da absorção de água em 24 horas; e nas primeiras 4 horas, esse valor sobe para $94 \%$.

A determinação da absorção de água é importante, pois é uma indicação da qualidade do agregado. Normas coreanas, por exemplo, fixam classes de agregados reciclados conforme a absorção de água que apresentam, relacionando- 
os com a sua utilização. Para os agregados graúdos existem 3 classes, I, II e III que representam, respectivamente, agregados com absorção de água menor que 3\%, $5 \%$ e 7\%. Agregados miúdos são divididos em duas classes, I e II, que apresentam respectivamente valores de absorção de água inferiores a 5\% e 10\%. A classe I é recomendada para uso em concreto estrutural, a classe II para concreto não estrutural, e a classe III para concreto não estrutural e material para base de pavimentos (YANG et al., 2008).

As recomendações da RILEM permitem a utilização de agregados reciclados com absorção máxima de $10 \%$ em concretos de categoria de resistência de até $50 \mathrm{MPa}$. Normas japonesas, ainda mais rígidas, fixam em 7\% a absorção máxima permitida para uso em concretos de categoria de resistência 24 MPa (JUAN, 2004).

\subsubsection{Massa específica aparente}

Os agregados reciclados são conhecidos pela sua qualidade inferior aos naturais devido à sua alta porosidade resultante da pasta de cimento aderida à sua superfície (TAM et al., 2007). De uma maneira geral, estes apresentam 65-70\%, em volume, de agregados miúdos e graúdos naturais; e $30-35 \%$ de pasta de cimento aderida (POON et al., 2004b).

Diversos autores relataram valores de massa específica aparente de agregados naturais comparando-os aos agregados reciclados. Em Hong Kong, por exemplo, os agregados naturais utilizados possuem massa específica aparente de 2,60-2,65 $\mathrm{g} / \mathrm{cm}^{3}$, enquanto os agregados reciclados apresentam 2,200-2,400 g/ $\mathrm{cm}^{3}$. Estes valores, todavia, podem variar consistentemente dependendo de diversos fatores.

Um destes fatores consiste nas propriedades do concreto dos quais os agregados foram retirados. Concretos que utilizaram relação água/cimento inferiores e aditivos pozolânicos são mais densos e menos porosos, gerando agregados reciclados com maior massa específica aparente e menor absorção (POON et al., 2004b).

Outro fator que influencia na massa específica aparente do agregado reciclado é a técnica de processamento utilizada para sua obtenção. Técnicas de britagem que 
produzem agregados com menor teor de pasta aderida, naturalmente, levam a agregados com maior massa específica aparente.

Além disso, a massa específica aparente depende do tamanho do agregado, haja vista que a quantidade de pasta aderida pode também depender deste fator. Como já explicado anteriormente, dependendo dos estágios de britagem, agregados reciclados menores podem possuir mais pasta aderida em sua composição, apresentando, portanto, menor massa específica aparente.

Carrijo (2005) afirma que a resistência de concretos produzidos com agregados reciclados está intimamente ligada à porosidade destes últimos, e, consequentemente, à sua massa específica aparente. Segundo a autora, agregados reciclados produzidos com resíduos de massa específica aparente inferior a 2,2 $\mathrm{g} / \mathrm{cm}^{3}$ apresentam resistência e módulo de elasticidade inferiores, tornando o concreto muito menos eficiente para aplicações estruturais. Em seu trabalho, a autora ainda mostrou que a influência da massa específica aparente dos agregados reciclados nas propriedades mecânicas do concreto é muito maior que a influência da natureza mineralógica dos mesmos.

\subsubsection{Granulometria}

A curva granulométrica dos agregados obtidos com a britagem de placas de concreto depende do método de britagem utilizado. Segundo a ACPA (2009) é possível ajustar as plantas de britagem de forma a se obter quase qualquer granulometria que se deseje, embora geralmente a quantidade de agregados miúdos gerados seja excessiva.

Segundo Oliveira e Assis (2001) o desempenho do concreto reciclado pode ser substancialmente melhorado com o peneiramento dos agregados reciclados e a seleção da composição granulométrica desejada. 


\subsubsection{Forma e textura}

Ensaios realizados por González-Fonteboa et al. (2001) de acordo com as normas europeias mostram que embora o coeficiente de forma seja similar para os agregados naturais e reciclados, os agregados naturais possuem, entretanto, textura menos rugosa que os reciclados.

Agregados reciclados de concreto possuem forma angular e relativamente pouco alongadas. Sua superfície é mais rugosa e porosa que a de agregados naturais, devido à presença de pasta aderida que é encontrada em praticamente todas as partículas de agregado reciclado. (BAIRAGl et al., 1993).

O tipo de britador utilizado também afeta o índice de forma. Britadores de impacto e de cone deixam os agregados com mais angulosidade, sendo os de mandíbulas mais recomendados quanto ao formato (JUAN, 2004).

Afirma-se, também, que quanto maior a relação a/c do concreto originário, mais arredondados são os agregados produzidos. (KIKUCHI et al., 1993 apud JUAN, 2004; KIKUCHI et al., 1993 apud GONÇALVES, 2007). Essa tendência é explicada pela menor resistência do concreto de origem, que permite um maior desgaste e erosão dos agregados graúdos reciclados (FONSECA, 2009).

\subsection{7 Índice de abrasão Los Angeles (Dureza)}

Os agregados reciclados apresentam maior índice de abrasão Los Angeles devido à maior susceptibilidade da pasta aderida aos agregados ao desgaste por abrasão (LÓPEZ-GAYARRE et al., 2009). O valor médio encontrado na literatura é em torno de $28 \%$ (JUAN, 2004).

Assim como as outras propriedades já apresentadas, o índice de abrasão depende do tamanho do agregado reciclado. Agregados com menores diâmetros apresentam maior índice de abrasão, haja vista a maior quantidade de pasta aderida presente (JUAN, 2004). O mesmo é esperado no que diz respeito às técnicas de processamento, aquelas que produzem agregados com menores quantidades de 
pasta aderida, naturalmente, produziram agregados com menores índices de abrasão.

Além disso, Hansen e Narud (1983) mostraram que quanto maior a relação a/c no concreto originário, maior é o índice de abrasão apresentado pelo agregado reciclado. Para relações a/c de 0,4; 0,7 e 1,2 os autores encontraram, nas frações de agregados reciclados 8-16, índice de abrasão Los Angeles de respectivamente $25 \%, 28 \%$ e $39 \%$; enquanto os agregados naturais virgens apresentavam somente $18,5 \%$.

Estudos posteriores mostram que quanto maior a resistência à compressão do concreto originário menor é o índice de abrasão apresentado pelo agregado produzido a partir deste (HANSEN, 1992).

O índice de abrasão Los Angeles, portanto, pode ser um bom indicador da qualidade do agregado, já que o ensaio é relativamente simples e pode indicar, grosseiramente, se o teor de pasta aderida ao agregado é muito elevado. Comparando dados advindos de diversos estudos, Juan (2004) observou que quanto maior o índice de abrasão maior é a absorção de água do agregado e menor é a massa específica aparente do mesmo.

\subsubsection{Teor de cloreto}

O teor de cloreto em agregados reciclados tende a ser maior que em agregados naturais. Se a quantidade é muito alta, o que ocorre principalmente em locais em que o concreto é exposto à salinidade (por exemplo, locais onde são jogados sais de degelo), deve-se atentar para que o conteúdo de cloreto não seja agravante para iniciar um processo de corrosão de armaduras no novo pavimento caso elas façam parte do projeto.

No projeto de reciclagem do pavimento da rodovia IH-10 em Houston, por exemplo, Won (2007) encontrou conteúdo de cloreto de $0,03 \mathrm{~kg} / \mathrm{m}^{3}$ no concreto com agregado reciclado e $0,005 \mathrm{~kg} / \mathrm{m}^{3}$ em concreto convencional. 
A FHWA recomenda que não sejam utilizados agregados reciclados provenientes de concreto contendo mais de $0,04 \mathrm{~kg}$ de cloreto $/ \mathrm{m}^{3}$ em pavimentos de concreto simples contendo barras de ligação e barras de transferência de carga e nos pavimentos continuamente armados (ACPA, 2009). A determinação da quantidade de cloretos em agregados reciclados, entretanto, pode resultar imprecisa, pois o aluminato de cálcio do cimento pode ter formado cloro aluminato cálcio hidratado, reduzindo, assim, o conteúdo de cloretos livres detectáveis no ensaio. Assim, muitos autores recomendam que para agregados reciclados deve-se quantificar a quantidade total de cloretos, não somente aqueles que se apresentam livres. (GULIKERS, 1996 apud JUAN, 2004; JUAN, 2004)

\subsection{PROPRIEDADES DO CONCRETO CONTENDO AGREGADOS RECICLADOS}

Concretos contendo agregados reciclados, quando comparados a concretos convencionais com os mesmos traços, apresentam resistência mecânica e módulo de elasticidade inferiores; permeabilidade, retração de secagem e fluência significativamente mais elevados; massa específica levemente inferior; coeficiente de expansão térmica mais elevado; e maior perda de trabalhabilidade (FRONDISTOU-YANNAS, 1980 apud MEHTA e MONTEIRO, 2008; FHWA, 2007 apud ACPA, 2009; ACI, 2001; HANSEN, 1986 apud ACPA, 2009).

Mehta e Monteiro (2008) afirmam que dosagens contendo agregados reciclados, quando comparadas a dosagens convencionais, geralmente apresentam pelo menos dois terços da resistência à compressão e módulo de elasticidade, e apresentam trabalhabilidade e durabilidade satisfatórias. No entanto, segundo os autores, a fração que corresponde ao agregado miúdo é inadequada para a produção de concretos, por conter grandes quantidades de pasta de cimento hidratado. 
As Tabelas 1.4 e 1.5 comparam, grosseiramente e segundo diferentes fontes, as propriedades do concreto com agregados reciclados não contaminados às do concreto com agregado natural.

Tabela 1.4 - Comparação das propriedades do concreto com agregados reciclados em relação às do concreto com agregado natural de composição semelhante.

(FRONDISTOU-YANNAS, 1980 apud MEHTA e MONTEIRO, 2008)

\begin{tabular}{ll}
\hline Resistência de aderência agregado-argamassa & \\
\hline \multicolumn{1}{c}{ Agregado graúdo, principalmente pedregulho de concreto antigo } & Comparável à de controle \\
\hline \multicolumn{1}{c}{ Agregado miúdo, principalmente argamassa de concreto antigo } & $55 \%$ daquela de controle \\
\hline Resistência à compressão & $64-100 \%$ daquela de controle \\
\hline Módulo de elasticidade estático na compressão & $60-100 \%$ daquele de controle \\
\hline Resistência à flexão & $80-100 \%$ daquela de controle \\
\hline Resistência ao gelo/degelo & Comparável à de controle \\
\hline Coeficiente de expansão térmica & Comparável ao de controle \\
\hline $\begin{array}{l}\text { Variações de comprimento de corpos de prova de concreto } \\
\text { armazenados por 28 dias a 90\% de umidade relativa e } 23^{\circ} \mathrm{C}\end{array}$ & Comparáveis às de controle \\
\hline Abatimento pelo tronco de cone & Comparável ao de controle \\
\hline
\end{tabular}

Tabela 1.5 - Comparação das propriedades do concreto com agregados reciclados graúdos e miúdos em relação às do concreto com agregado natural de composição semelhante

(adaptado de FHWA, 2007 apud ACPA, 2009; ACI, 2001; HANSEN, 1986 apud ACPA, 2009)

Variações esperadas de misturas similares utilizando agregados virgens

\begin{tabular}{ccc}
\hline Propriedade & Uso de agregado graúdo reciclado & $\begin{array}{c}\text { Uso de agregado graúdo e miúdo } \\
\text { reciclado }\end{array}$ \\
\hline $\begin{array}{c}\text { Resistência à } \\
\text { compressão }\end{array}$ & $0 \%$ a $24 \%$ menor & $15 \%$ a $40 \%$ menor \\
\hline $\begin{array}{c}\text { Resistência à } \\
\text { tração }\end{array}$ & $0 \%$ a $10 \%$ menor & $10 \%$ a $20 \%$ menor \\
\hline $\begin{array}{c}\text { Variação na } \\
\text { resistência }\end{array}$ & maior & maior \\
\hline $\begin{array}{c}\text { Módulo de } \\
\text { elasticidade }\end{array}$ & $10 \%$ a 33\% menor & $25 \%$ a $40 \%$ menor \\
\hline $\begin{array}{c}\text { Coeficiente de } \\
\text { expansão térmica }\end{array}$ & $0 \%$ a 30\% maior & $0 \%$ a $30 \%$ maior \\
\hline $\begin{array}{c}\text { Retração por } \\
\text { secagem }\end{array}$ & $20 \%$ a 50\% maior & $70 \%$ a $100 \%$ maior \\
\hline Fluência & $30 \%$ a $60 \%$ maior & $30 \%$ a $60 \%$ maior \\
\hline Permeabilidade & $0 \%$ a 500\% maior & $0 \%$ a $500 \%$ maior \\
\hline $\begin{array}{c}\text { Massa específica } \\
\text { aparente }\end{array}$ & $0 \%$ a 10\% menor & $5 \%$ a $15 \%$ menor \\
\hline
\end{tabular}

Segundo as Tabelas 1.4 e 4.5, a característica mecânica menos afetada é a resistência à tração, enquanto a que sofre maiores quedas é o módulo de elasticidade. Essa tendência de comportamento indica que o uso de agregados 
reciclados de concreto em pavimentos de concreto pode ser uma boa aplicação para o material, já que nesse caso de utilização é favorável que o concreto apresente boa resistência à tração na flexão e menor de módulo de elasticidade. Por outro lado, a retração por secagem nos concretos reciclados, nitidamente superior, exige grande rigor no processo construtivo.

Entretanto, apesar dessas tendências no comportamento do concreto contendo agregado reciclado terem sido observadas por diversos autores nacionais e internacionais, existem ainda muitos casos relatados em que o comportamento do concreto difere do apresentado nas Tabelas 1.4 e 1.5 .

\subsubsection{Trabalhabilidade}

A alta absorção apresentada pelos agregados reciclados provoca maior perda de trabalhabilidade por parte dos concretos produzidos a partir destes quando a mistura é mantida a mesma (sem adição de água de compensação devido à absorção de água dos agregados ou pré-molhagem dos mesmos). Entretanto, existem outros fatores ligados aos agregados reciclados que também colaboram para isso, tais como a maior angularidade e rugosidade (DE VRIES, 1996; SPRINGENSCHMID e SODEIKAT, 1998; ZAHARIEVA et al., 2003). Para agregados graúdos reciclados, a forma e a rugosidade da superfície dos agregados não são tão agravantes para a trabalhabilidade, mas o uso de agregados miúdos reciclados pode afetá-la significativamente (YRJANSON, 1989).

Em estudo feito com substituição de agregados graúdos naturais por reciclados, sem aumento da quantidade de água na mistura, Yang et al. (2008) demonstraram que o abatimento (slump) inicial do concreto fresco decrescia levemente com o aumento do teor de substituição dos agregados. Contudo, não observaram nenhuma relação clara entre o abatimento inicial e a absorção de água dos agregados reciclados. Seus resultados mostraram que maiores valores de absorção e teores de substituição dos agregados levam a maiores perdas de trabalhabilidade no tempo. Isso ocorre porque o agregado reciclado continua a absorver água após a mistura com o concreto. 
Os autores concluem que o tipo e o teor de substituição dos agregados têm um efeito muito maior na perda de trabalhabilidade do que no abatimento inicial. Considerando $\mathrm{Qw}{ }^{4}$ como sendo a absorção de água dos agregados relativa e $\mathrm{k}^{5}$ como sendo a declividade da reta de perda de trabalhabilidade em função do tempo, o estudo de Yang et al. (2008) apresentou os resultados ilustrados na Figura 1.23.

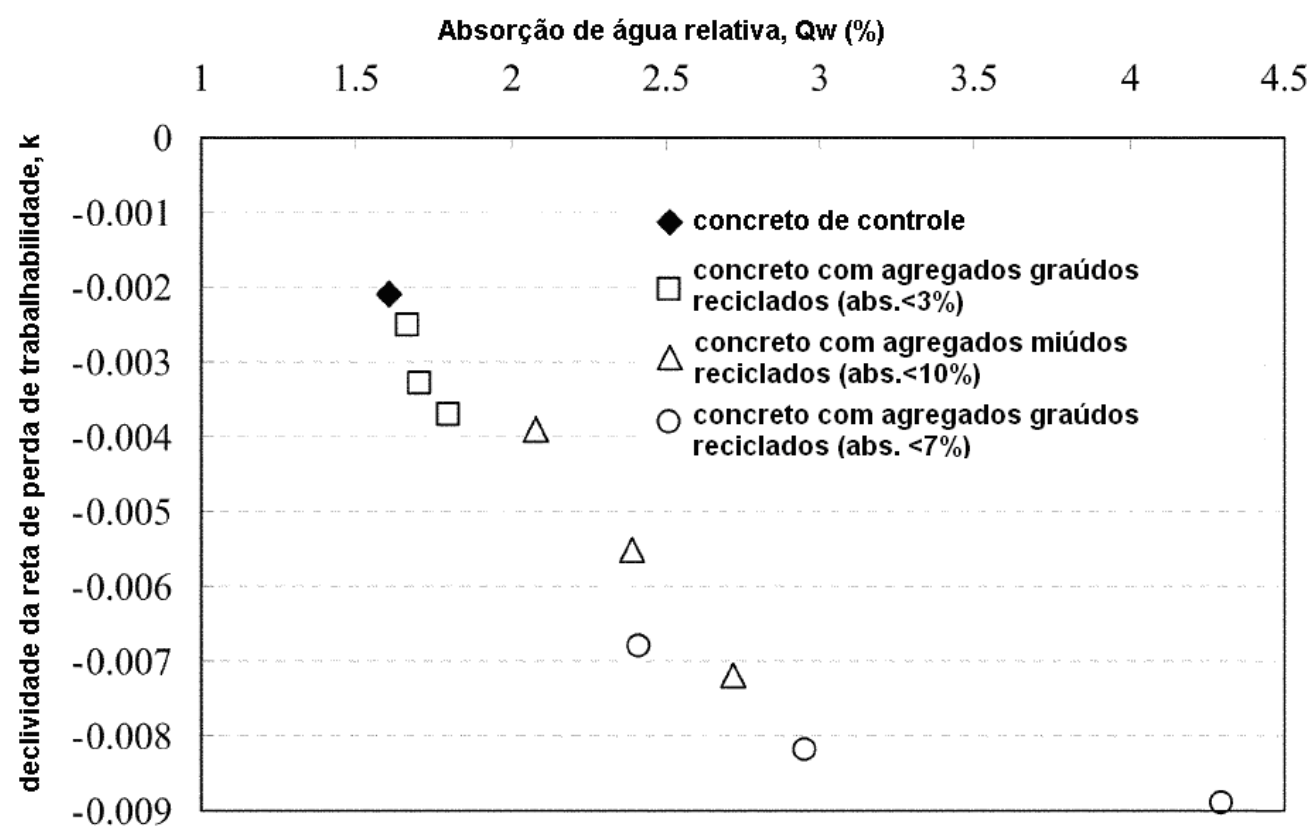

Figura 1.23 - Influência de Qw em k (adaptado de YANG et al., 2008)

Outro estudo feito por Nealen e Ruhl (1997) comparando um concreto de controle e um concreto contendo agregado reciclado, ambos com o mesmo traço e mesma relação a/c, apresentou perda de fluidez conforme se apresenta na Figura 1.24.

${ }^{4} Q_{W}=\frac{a Q_{N G}+b Q_{N S}+c Q_{R G}+d Q_{R S}}{a+b+c+d}$

Onde $Q_{N G}, Q_{N S}, Q_{R G}$ e $Q_{R S}$ são os valores de absorção de água dos agregados graúdos naturais, miúdos naturais, graúdos reciclados e miúdos reciclados respectivamente; e 'a', 'b', 'c' e 'd' são os volumes unitários $\left(\mathrm{L} / \mathrm{m}^{3}\right)$ de agregados graúdos naturais, miúdos naturais, graúdos reciclados e miúdos reciclados respectivamente

$5 \frac{S_{L}}{\left(S_{L}\right)_{i}}=k T+1$

Onde $\left(\mathrm{S}_{\mathrm{L}}\right) \mathrm{i}$ é o slump inicial do concreto e T é o tempo decorrido até se atingir o slump $\mathrm{S}_{\mathrm{L}}$ 


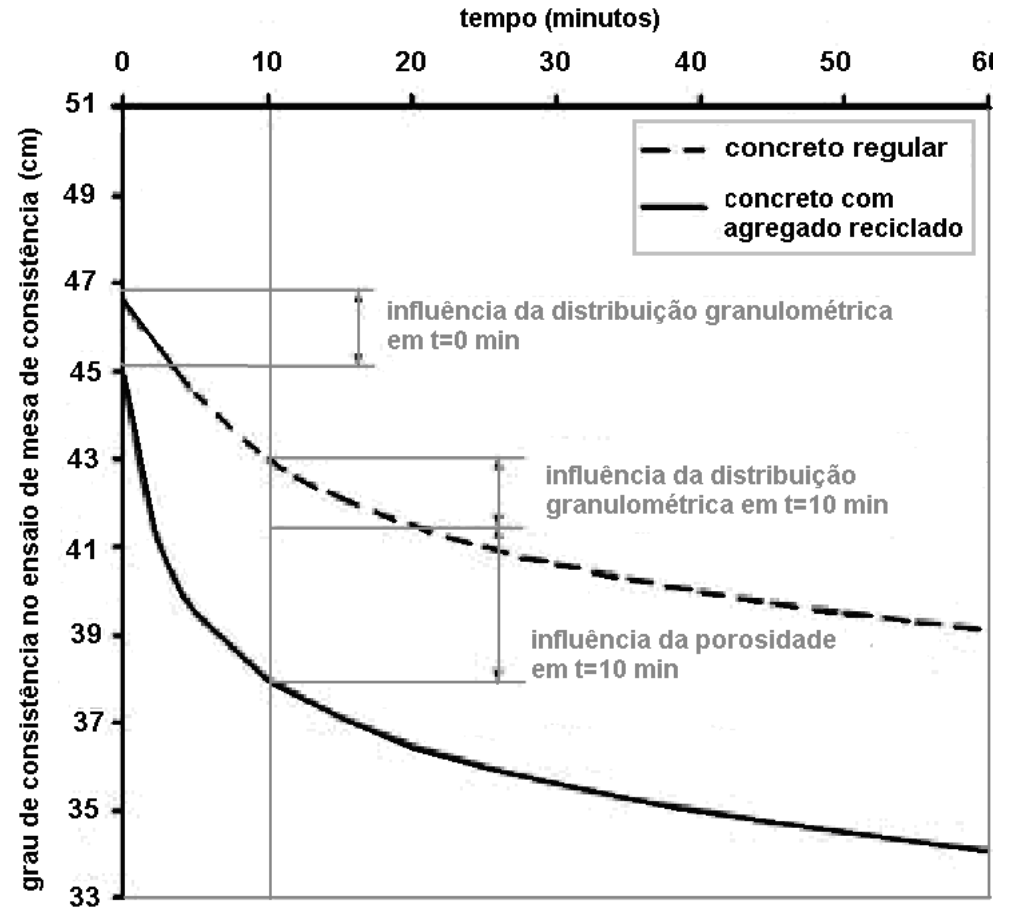

Figura 1.24 - Desenvolvimento da consistência (adaptado de NEALEN e RUHL, 1997)

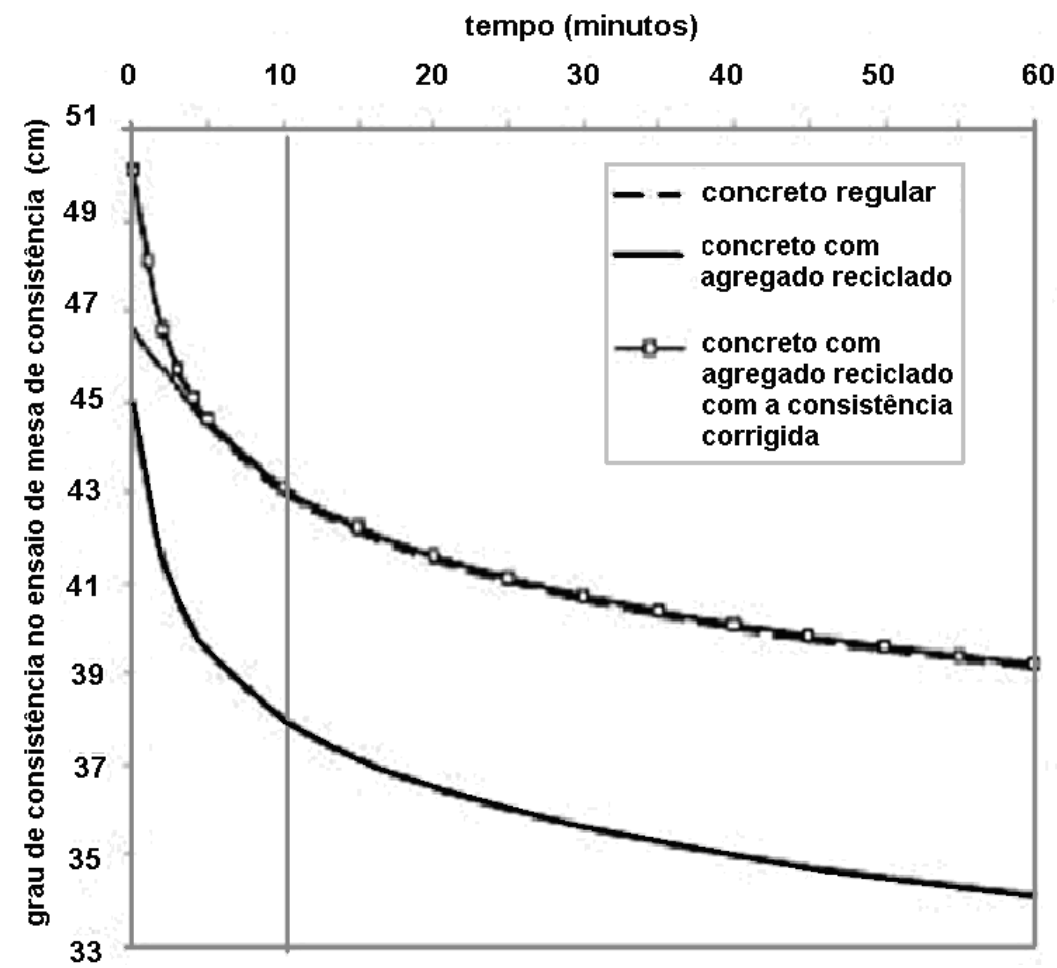

Figura 1.25 - Desenvolvimento da consistência através da adição de água (adaptado de NEALEN e RUHL, 1997)

As curvas apresentadas mostram que o agregado reciclado apresenta um rápido ganho de consistência nos primeiros 10 minutos da mistura. Após esse intervalo, as curvas se comportam de maneira praticamente paralelas. Além disso, existe 
também uma diferença na consistência devido à granulometria dos agregados, que também deve ser levada em conta.

Quando água foi adicionada à mistura para compensar a alta perda de trabalhabilidade inicial devida à absorção de água dos agregados, o desenvolvimento da consistência apresentou-se conforme a Figura 1.25.

Poon et al. (2004a) demonstraram que o abatimento inicial depende da quantidade de água livre inicial, enquanto que a perda de trabalhabilidade com o tempo está mais relacionada ao estado inicial de umidade dos agregados.

A fim de minimizar a perda de trabalhabilidade devido à utilização de agregados reciclados, diversos autores propõem medidas tais como o uso de aditivos, a prémolhagem dos agregados e o aumento da quantidade de água adicionada à mistura (a fim de se conseguir a condição de saturação com superfície seca dos agregados sem alteração da relação a/c efetiva na mistura). Juan e Gutiérrez (2004) chegaram a encontrar até um aumento na trabalhabilidade ao utilizar os agregados reciclados pré-molhados, o que foi explicado pelo índice de forma e pela curva granulométrica do agregado reciclado utilizado.

Foi relatado por Poon et al. (2007) que o abatimento inicial aumenta com o aumento da porcentagem de agregados graúdos reciclados quando estes são secos ao ar e é acrescentada água na mistura de acordo com o valor de absorção de água dos agregados reciclados em 24 horas (ou seja, a fim de que os agregados reciclados alcancem condição de saturação com superfície seca). Além disso, a perda de trabalhabilidade com o tempo, nessas condições, é maior no concreto convencional. Os mesmos autores observaram que na primeira hora a perda de trabalhabilidade é mais acentuada no caso do uso de agregados reciclados, mas após esse período ela é desacelerada. Enquanto o concreto convencional perdia toda sua trabalhabilidade (abatimento nulo) em 130 minutos, o concreto contendo agregados reciclados levava 3 horas para tanto. A Figura 1.26 ilustra a perda de trabalhabilidade observada pelos autores para concretos com teores de substituição de agregados naturais por reciclados desde 0\% (R0) até 100\% (R100). 


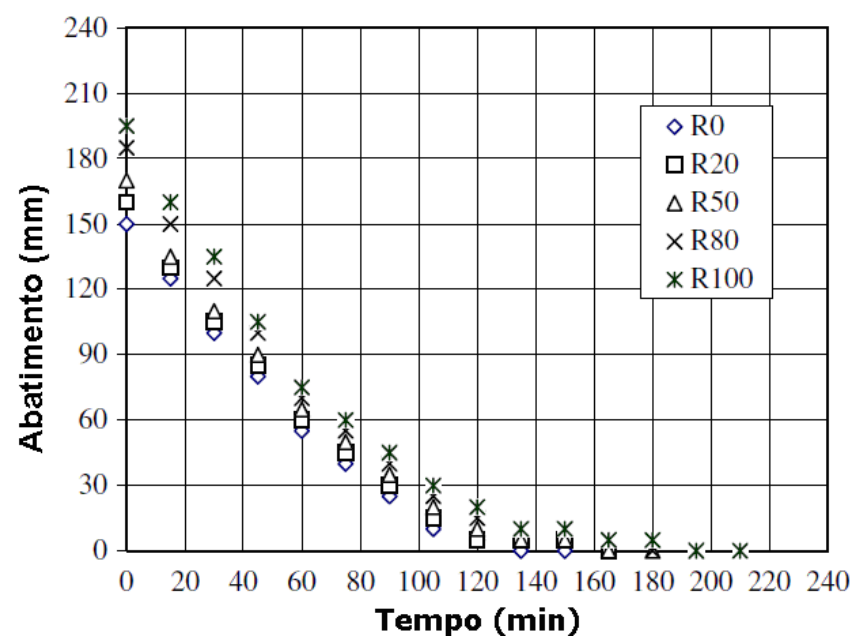

Figura 1.26 - Perda de trabalhabilidade das misturas de concreto (adaptado de POON et al., 2007)

Leite (2001), adotando a diretiva de pré-umedecimento dos agregados reciclados com quantidade de água correspondente à absorção dos agregados reciclados aos 10 minutos (conforme seu estudo: $50 \%$ da absorção média do agregado miúdo reciclado e $40 \%$ da absorção média do agregado graúdo reciclado), observou que nos primeiros 15 minutos a perda de abatimento é maior para concretos reciclados quando comparados a concretos de referência (Figura 1.27). Isso ocorre devido à absorção de água da mistura por parte dos agregados reciclados no início da mistura. Após esse período, a autora observou que a perda de trabalhabilidade é menor para o concreto com $50 \%$ de agregados miúdos reciclados sem agregados graúdos reciclados, comportamento que foi explicado pelo fato de o material absorver maiores quantidades de água nos primeiros minutos, podendo ter chegado ao seu estado de saturação quase completa aos 15 minutos, portanto, com a absorção de água pelo agregado reduzida. No concreto com teor de agregado graúdo reciclado de $50 \%$ e sem agregado miúdo reciclado, entretanto, o comportamento observado não foi 0 mesmo. A autora atribuiu a esse comportamento a explicação de que a fração graúda do material reciclado absorve água mais lentamente, demorando mais para atingir a saturação completa em relação à fração miúda. 


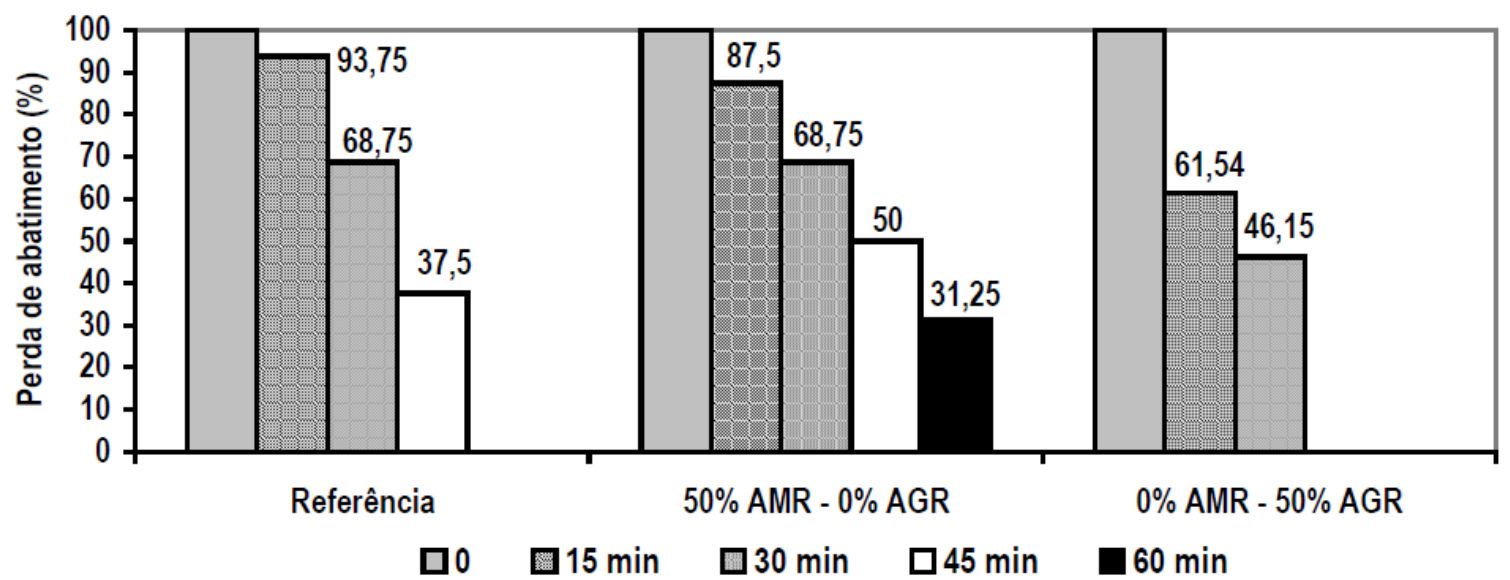

Figura 1.27 - Percentuais de abatimento em relação à leitura inicial de cada traço (concreto de referência, concreto com $50 \%$ de agregado miúdo reciclado- AMR - e concreto com $50 \%$ de agregado graúdo reciclado - AGR) (LEITE, 2001)

Estudo apresentado por Ravindrarajah e Tam (1987) observou que a substituição de agregados miúdos convencionais por reciclados (sem a utilização de agregados graúdos reciclados) não acarretou grande impacto na trabalhabilidade do concreto.

Entretanto, diversos estudos atestam que o uso de agregados miúdos reciclados pode acarretar perda considerável de trabalhabilidade, tanto devido à sua alta absorção de água quanto ao seu formato mais anguloso, e, portanto, muitos autores não o recomendam.

Cabe ressaltar que a escolha do tipo de britador a ser utilizado pode afetar a trabalhabilidade do concreto, já que influencia no formato do agregado produzido. Agregados mais angulosos levam a maior consistência e, portanto, maior perda de trabalhabilidade.

\subsubsection{Massa específica do concreto no estado fresco}

A massa específica do concreto contendo agregados reciclados no estado fresco tende a ser menor que a do concreto convencional, haja vista a alta porosidade apresentada pelos agregados reciclados. Carrijo (2005) observou que a influência relativa da massa específica aparente do agregado na do concreto é maior que aquela da relação a/c. Em seu estudo com utilização de agregados graúdos provenientes de RCD, a massa específica dos concretos aumentou $3,5 \%$ quando a relação a/c passou de 0,67 para 0,4 ; enquanto que 0 aumento foi de 
aproximadamente $20 \%$ quando a massa específica aparente dos agregados passou de 1,74 para $2,68 \mathrm{~g} / \mathrm{cm}^{3}$.

\subsubsection{Exsudação}

Não existe um consenso a respeito do comportamento do concreto contendo agregados reciclados em relação à exsudação. Yang et al. (2008) encontraram resultados que mostram que a exsudação com o tempo decresceu com o aumento da absorção de água dos agregados reciclados. Em seus ensaios utilizaram agregados reciclados no estado saturado com superfície seca, e não acrescentaram mais água com a substituição dos agregados na mistura. Kim et al. (1993) apud Yang et al. (2008) também concluíram, por seus testes, que o total de exsudação do concreto decresce com o aumento da parcela de agregados naturais substituída por reciclados.

Poon et al. (2007), ao contrário desses autores, mostraram que a exsudação aumenta com o acréscimo do teor de substituição dos agregados. Em seu experimento, entretanto, utilizaram agregados em condição de umidade do ambiente e acrescentaram água para compensar a quantidade de água que poderia ser absorvida pelos agregados na mistura.

\subsubsection{Resistência à compressão}

Segundo Hendricks (1994) apud Vancura et al. (2009), embora a presença de uma camada de pasta aderida no agregado reciclado dificulte a mistura do concreto, essa característica pode levar a uma boa ligação entre a antiga pasta e a nova, resultando em bons desempenhos quanto à resistência mecânica do novo concreto.

Springenschmid e Sodeikat (1998) relataram um caso de utilização de material proveniente uma rodovia alemã em que a utilização de agregados graúdos reciclados resultou em concretos com maior resistência à compressão. Em seu estudo utilizaram agregados reciclados em várias proporções (Figura 1.28) compensando a perda de trabalhabilidade com o uso de plastificantes (sem utilizar o conceito de relação a/c efetiva) e observaram que quanto maior a quantidade de 
agregados reciclados na mistura maior era a resistência a compressão apresentada pelo concreto (Figura 1.29).

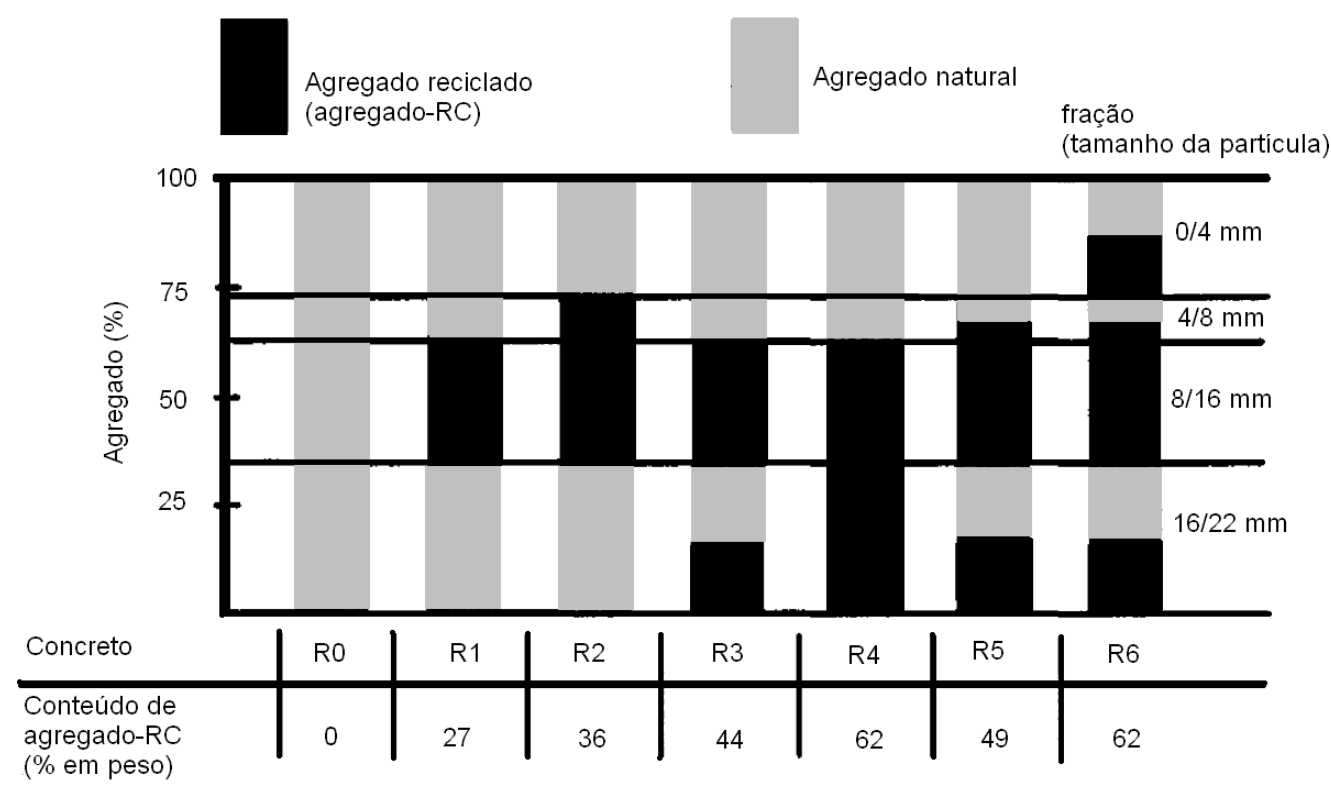

Figura 1.28 - Quantidade de agregados reciclados nas misturas de concreto R0 a R6 (adaptado de SPRINGENSCHMID e SODEIKAT, 1998)

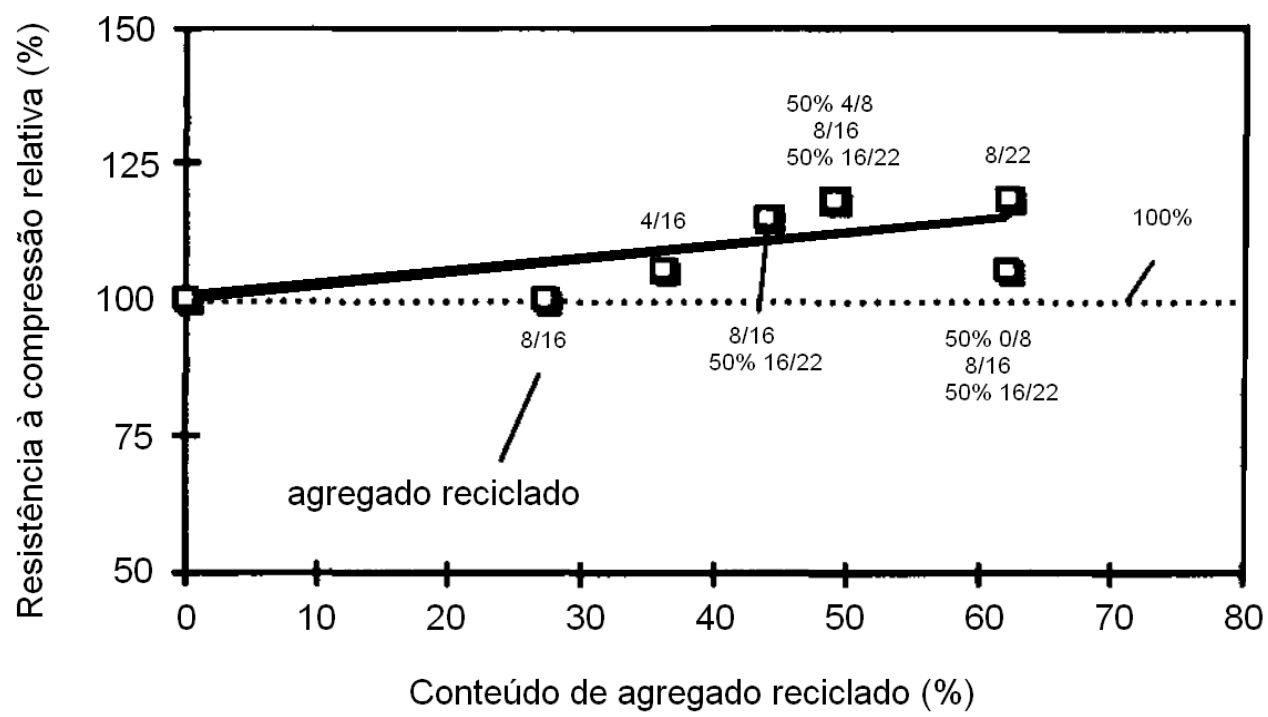

Figura 1.29 - Resistência à compressão normalizada com a resistência à compressão do concreto de referência R0 (adaptado de SPRINGENSCHMID e SODEIKAT, 1998)

Em estudo feito em laboratório por Salem e Burdette (1998) também foi observada a mesma tendência de aumento de resistência com a utilização de agregados graúdos reciclados. Para explicar esse comportamento, os autores citam duas possíveis causas: a forma mais angulosa e textura mais rugosa do agregado reciclado, que colabora para uma melhor adesão e intertravamento entre os 
agregados e a pasta de cimento; e a absorção de água por parte dos agregados durante a mistura, levando à redução da relação a/c efetiva (calculada descontandose a absorção de água por parte dos agregados).

Ravindrarajah e Tam (1987), ao substituírem somente agregados miúdos naturais por reciclados, e compensando a água de absorção (a/c efetiva do concreto constante) obtiveram resistência à compressão nas idades de 7 e 90 dias de aproximadamente 0,85 e 1,12 aquela do concreto de controle. Segundo os autores, a resistência do novo concreto depende de dois fatores combinados: a melhora da resistência devido à presença de partículas de cimento não hidratadas nos reciclados, e a redução da resistência devido ao aumento da porosidade do concreto com a presença de agregados reciclados. Cabe ressaltar, que no estudo realizado pelos autores, o concreto originário foi curado por somente 28 dias antes de ser britado para produção dos agregados reciclados.

A maioria dos estudos já realizados mostra que a resistência do concreto contendo agregados reciclados com mesma relação a/c efetiva tende a ser inferior àquela do concreto convencional, e tanto menor conforme se aumenta o teor de substituição de agregados. Isso ocorre devido ao aumento da quantidade de água absorvida, da exsudação ao redor do agregado graúdo e da estrutura enfraquecida da pasta porosa em volta dos agregados (UCHIKAWA e HANEHARA, 1996; KOBAYASHI e HAMADA, 2007; GÓMEZ-SOBERÓN, 2002; VANCURA et al., 2009; POON et al., 2004b; SANI et al., 2005). Hendricks (1996) afirma que é possível obter uma relação linear entre a massa específica aparente dos agregados e a resistência do concreto quando a qualidade da matriz de cimento é a mesma.

Bijen (1996) e Hendricks (1996) relatam que a perda de resistência à compressão com o uso de agregados reciclados de concreto pode chegar a $35 \%$, e que para compensá-la seria necessário aumentar o teor de cimento em 20 a $40 \mathrm{~kg} / \mathrm{m}^{3}$. Outros estudos indicam que devem ser acrescentados $5 \%$ a mais de cimento para que se obtenha a mesma resistência no caso de substituição total de agregados graúdos e $15 \%$ a mais no caso do emprego de agregados graúdos e miúdos reciclados (HANSEN e NARUD, 1983; HANSEN, 1992). Ricci (2007) relata, para o caso de concreto compactado com rolo, aumento de $9 \%$ no consumo de cimento para 
obtenção de mesma resistência do concreto de controle com o uso de agregados graúdos reciclados.

A resistência do concreto depende da resistência da pasta de cimento, dos agregados e da interface pasta-agregado. Segundo Gonçalves e Machado Jr. (2001), a porosidade da matriz e a zona de transição são as fases mais significativas e com maior grau de influência na resistência apresentada pelo concreto. Klemt (1997) afirma que o concreto reciclado rompe por falta de aderência entre o agregado reciclado e a argamassa nova, ou pela falta de aderência entre o agregado natural e a argamassa aderida a este.

Para Etxeberria et al. (2007), porém, apesar de em concretos convencionais a interface ser o ponto mais fraco do concreto, com o uso de agregados reciclados o ponto mais fraco pode ser o agregado se a pasta de cimento aderida ao agregado reciclado apresentar resistências inferiores à nova pasta. Segundo os autores não seria econômico utilizar $100 \%$ de agregados graúdos reciclados no concreto para se atingir altas resistências, pois o consumo de cimento teria que aumentar de forma não economicamente justificável, sendo, portanto, o uso destes, recomendado somente para concretos de resistências entre 20 e 45 MPa. Di Niro et al. (1996) ainda afirmam que a resistência máxima possível de se obter com o uso de agregados reciclados é de 35 a $40 \mathrm{MPa}$, não sendo possível utilizá-los em concretos de alta resistência.

No gráfico da Figura 1.30 são apresentados resultados de resistência à compressão obtidos por Won (2007). Pode-se observar que apesar da tendência de concretos contendo agregados reciclados apresentarem menor resistência à compressão, esse comportamento não é acentuado, possibilitando o emprego dessa solução tranquilamente se feitas algumas adaptações na mistura. 


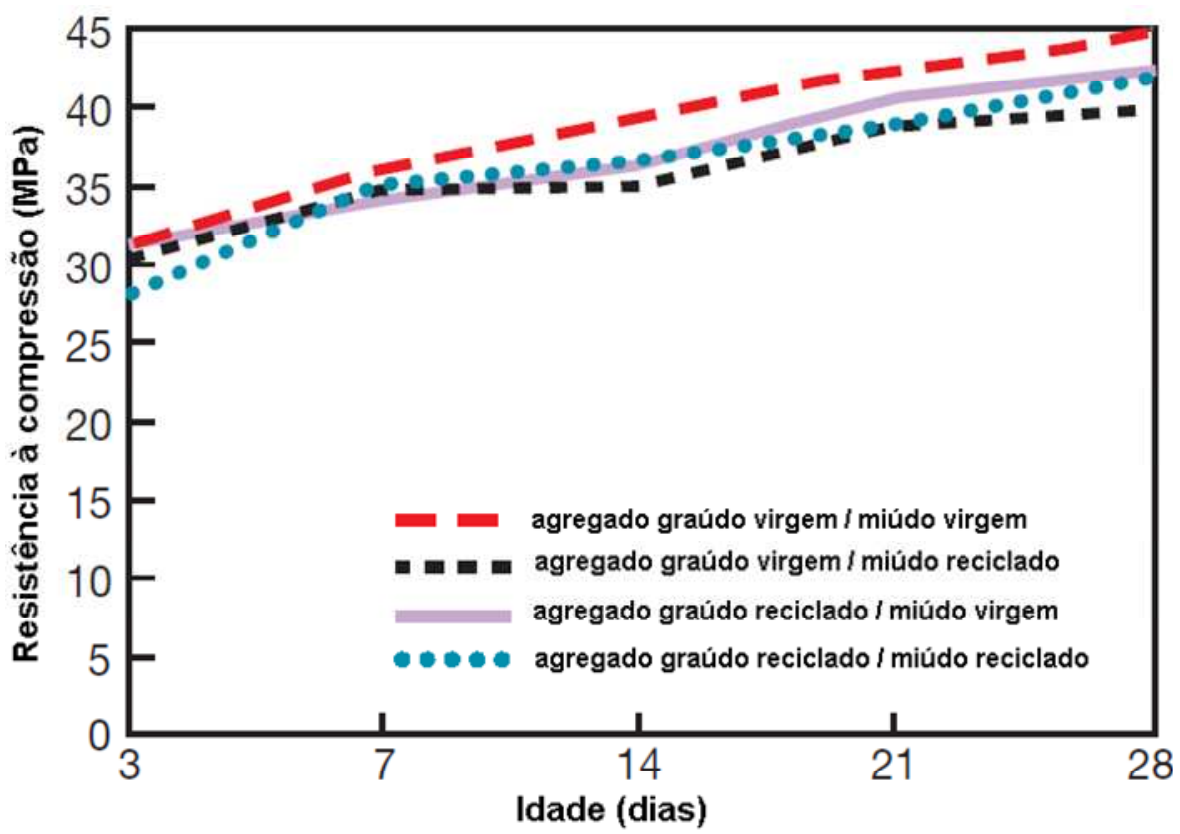

Figura 1.30 - Resistência à compressão de concretos contendo diferentes combinações de agregados graúdos e miúdos (adaptado de WON, 2007 apud ACPA, 2009)

Nagataki et al. (2004) alcançaram melhores resultados de resistência à compressão e à tração para concretos produzidos com agregados reciclados quando comparados aos convencionais. Esse comportamento foi explicado pelo fato de as maiores concentrações de fissuras, nos materiais utilizados, estarem no agregado graúdo. Quando o concreto era britado para gerar o material reciclado, essas fissuras desapareciam, ficando os agregados reciclados com características mecânicas melhores que os agregados originais. Outra explicação vem do fato que materiais com comportamentos elásticos semelhantes, quando atuando juntos, resultam em menores níveis de tensão na zona interfacial (BREMNER e HOLM, 1986), e, portanto, têm uma vantagem em termos de desempenho mecânico.

Juan (2004) comenta que estudos nos quais são obtidos aumentos de resistência são, geralmente, aqueles em que o concreto originário possui elevada resistência; e estudos que apresentaram maiores quedas de resistência são aqueles em que o concreto originário procede de concreto de baixa resistência. A mesma autora ainda afirma que ao se comparar diversos estudos, quanto mais resistente o concreto obtido, maior a diferença apresentada entre a resistência do concreto de controle e do concreto reciclado (Figura 1.31). 


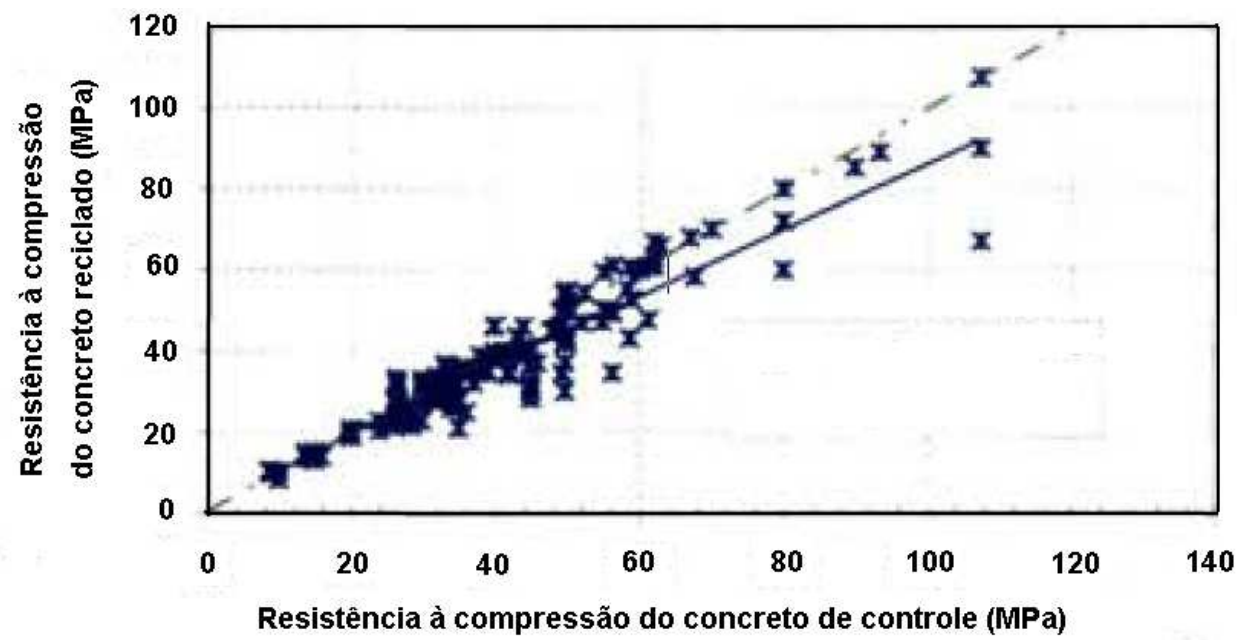

Figura 1.31 - Relação entre a resistência à compressão do concreto de controle e do concreto reciclado com substituição total dos agregados (adaptado de JUAN, 2004)

\subsubsection{Resistência à tração}

Estudo comparativo feito por Juan (2004) mostra que na literatura encontrada pela autora, ao se comparar a resistência à tração de concretos com substituição de agregados graúdos naturais por reciclados com a de concretos de controle, há, na média, uma leve queda nessa resistência com os reciclados (Figuras 1.32 e 1.33).

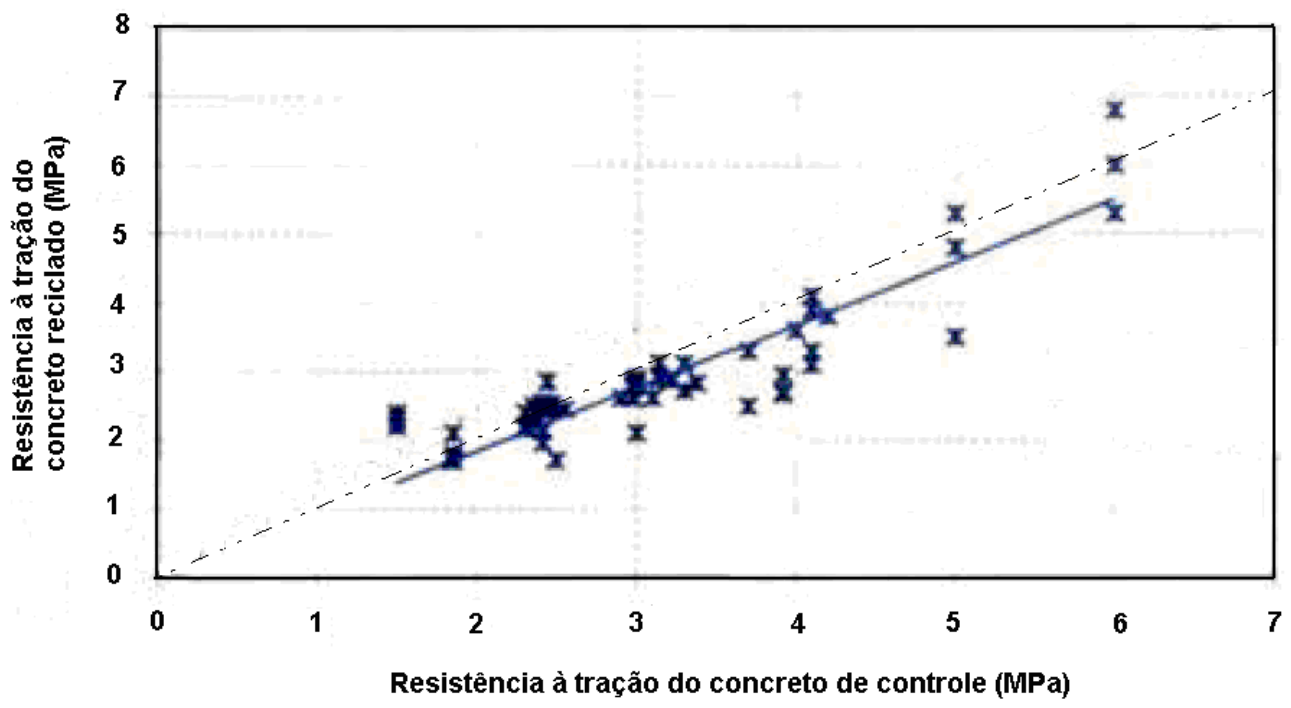

Figura 1.32 - Relação entre a resistência à tração indireta do concreto de controle e do concreto reciclado com substituição total dos agregados (adaptado de JUAN, 2004) 


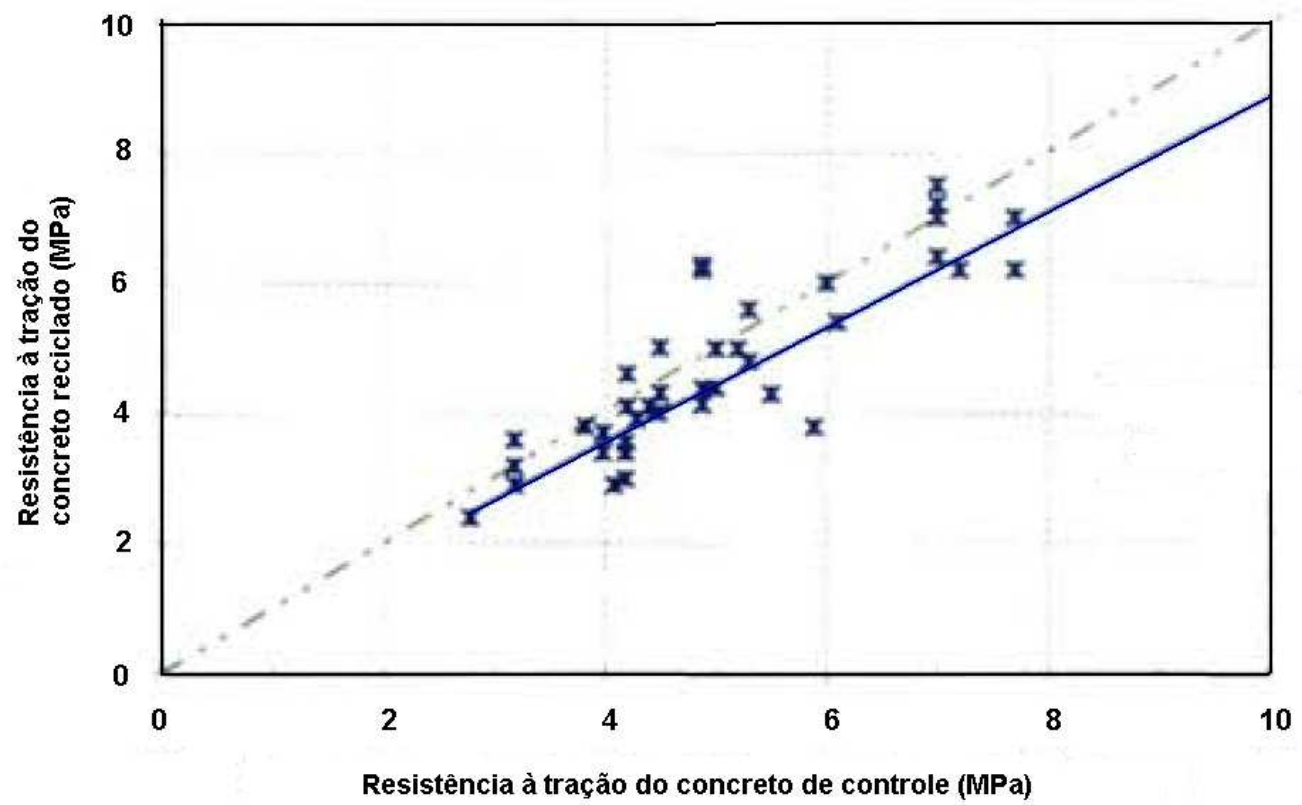

Figura 1.33 - Relação entre a resistência à tração na flexão do concreto de controle e do concreto reciclado com substituição total dos agregados (adaptado de JUAN, 2004)

Etxeberria et al. (2007) comentam que é possível obter maiores valores de resistência à tração por compressão diametral em concretos feitos com agregados graúdos reciclados se comparados aos concretos de controle devido à maior eficácia da nova zona de interface, que por sua vez é decorrente da menor relação a/c efetiva nessa área devido à absorção de água dos agregados.

Salem e Burdette (1998) observaram, com o uso de agregados graúdos reciclados, porém sem a adição de água a fim de manter a relação a/c efetiva constante, melhores resistências à tração na flexão a menores idades e um decréscimo posterior. Segundo Mehta (1986), em idades menores uma textura mais rugosa pode ajudar na formação de uma ligação forte entre a pasta de cimento e o agregado, colaborando para a resistência à tração do concreto; contudo, com o passar do tempo, interações químicas entre o agregado e a pasta começam a se tornar mais relevantes que a textura do agregado.

Diversos outros autores observaram em seus estudos que tanto em laboratório como em campo os resultados indicam valores similares ou maiores de resistência à tração da flexão para concretos contendo agregados reciclados em comparação aos convencionais. 
Apesar de muitos autores observarem melhores resistências à tração na flexão em concretos contendo agregados reciclados se comparados aos concretos de controle (convencionais), existem também casos de autores que não relatam nenhuma tendência no comportamento do concreto à tração com o uso de agregados reciclados (LÓPEZ-GAYARRE et al., 2009), e outros que relatam perda de resistência em até 35\% (HENDRICKS, 1996). Bairagi et al. (1993), por exemplo, relatam em concretos com teor de substituição de agregados graúdos de $25 \%$ e $50 \%$, valores de resistência à tração na flexão de 94\% a $87 \%$ do valor integral para o concreto de referência.

Estes mesmos autores encontraram a seguinte relação entre a resistência à compressão e a resistência à tração na flexão para concretos conforme o teor de substituição de agregados graúdos adotada:

$$
\begin{gathered}
f_{c t, s p}=\beta \sqrt{f_{c}} ;(0 \leq r \leq 1,0) \\
\beta=\beta(r)=(0,824-0,164 r)
\end{gathered}
$$

onde:

$\mathrm{f}_{\mathrm{ct}, \mathrm{sp}}$ : resistência à tração na flexão (MPa)

$\mathrm{f}_{\mathrm{c}}$ : resistência à compressão $(\mathrm{MPa})$

r: teor de substituição de agregados graúdos naturais por reciclados

Juan e Gutiérrez (2004), utilizando a equação descrita nas normas espanholas EHE - eq.(3) - para concretos convencionais relacionando a resistência à compressão com a resistência à tração indireta, relataram que esta continua válida para o caso do uso de agregados reciclados independente do teor de substituição adotado.

$$
f_{t}=0,33 \cdot \sqrt[3]{\left(f_{c m}-8\right)^{2}}
$$

onde:

$\mathrm{f}_{\mathrm{t}}$ : resistência à tração indireta $(\mathrm{MPa})$

$\mathrm{f}_{\mathrm{cm}}$ : resistência à compressão $(\mathrm{MPa})$ 


\subsubsection{Módulo de elasticidade}

A substituição de agregados naturais por agregados reciclados, com consequente aumento da porosidade, leva a uma redução do módulo de elasticidade do concreto com material reciclado quando comparado ao concreto de referência. Segundo Juan (2004), o módulo de elasticidade é a propriedade do concreto reciclado que experimenta maiores quedas, sendo que em concretos de baixa relação a/c essa queda é mais acentuada. Assim, a relação entre a resistência à compressão e o módulo de elasticidade não permanece ao se substituir os agregados por reciclados. Esse comportamento, segundo, Gonçalves e Machado Jr. (2001), é ainda maior no caso da utilização de agregados miúdos reciclados.

Para um concreto de $30 \mathrm{MPa}$ é prevista uma redução de aproximadamente $15 \%$ no valor do módulo de elasticidade quando o agregado graúdo natural é integralmente substituído por agregado reciclado (LEVY e HELENE, 2001). González-Fonteboa et al. (2001) observaram queda de 10\% no módulo de elasticidade de concretos com substituição de agregados graúdos naturais por reciclados em $50 \%$. Kou et al. (2007) encontraram perdas de $28 \%$ para um concreto de $55 \mathrm{MPa}$ com substituição de agregados graúdos em 100\%; e para este mesmo teor de substituição, LópezGayarre et al. (2009) encontraram perdas de 26\%. E Ricci (2007), com utilização de agregados reciclados de concreto provenientes de revestimento de pavimento em concreto compactado com rolo, encontraram queda de aproximadamente $27 \%$ no valor de módulo.

Eickschen e Siebel (1998) relataram redução de $20 \%$ no módulo de elasticidade de concretos com agregados graúdos reciclados; e com o concreto com substituição total da areia natural por areia reciclada, essa redução era acrescida de $10 \%$.

Em estudo relatado por Ravindrarajah e Tam (1987) a redução no módulo de elasticidade aos 28 dias, quando somente agregados miúdos foram substituídos por reciclados, foi de $15 \%$ no módulo de elasticidade estático e $20 \%$ no dinâmico.

Etxeberria et al. (2007) explicam que essa redução no módulo de elasticidade vem do fato de os agregados reciclados possuírem um módulo de elasticidade inferior 
aos agregados naturais, sendo que o módulo de elasticidade do concreto depende significantemente do módulo de elasticidade dos agregados. Quanto maior a quantidade de pasta de cimento porosa aderida, menor será o módulo de elasticidade do agregado reciclado.

Resultados de investigação feita pelo Building Contractors Society of Japan (1978) apud $\mathrm{ACl}$ (2001) mostram que reduções no módulo de elasticidade de concretos feitos com agregados graúdos e miúdos reciclados variaram de $25 \%$ a $40 \%$, enquanto para concretos feitos somente com agregados graúdos reciclados a variação foi de $10 \%$ a 33\%. Esses resultados são apresentados na Figura 1.34.

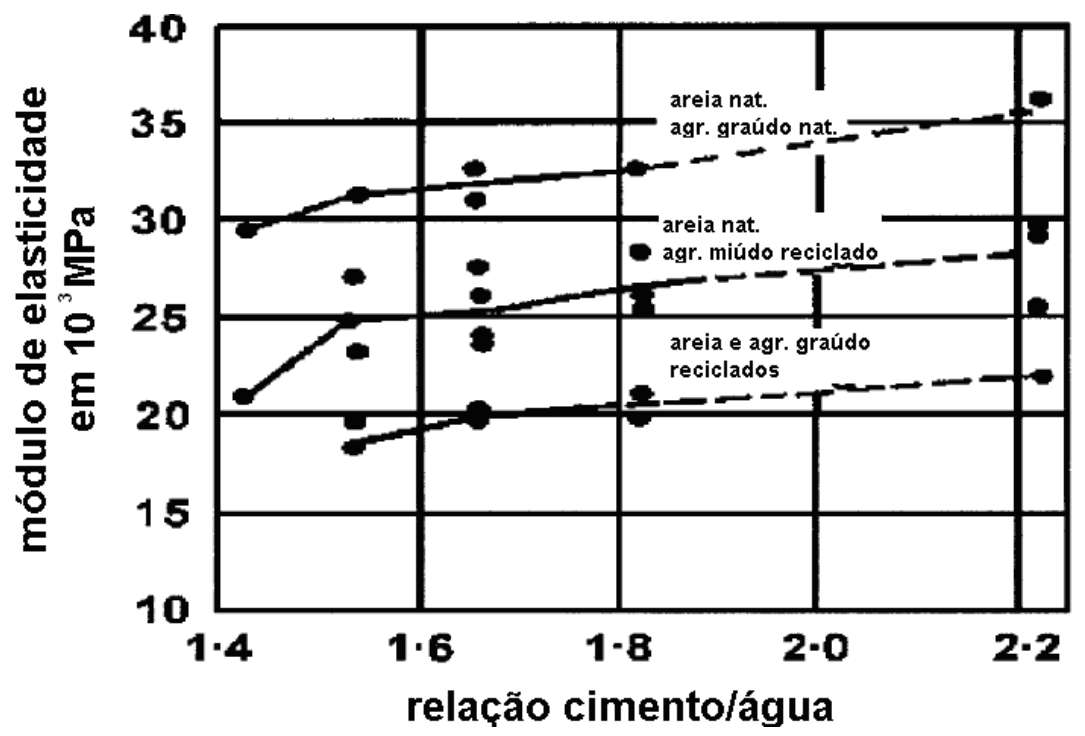

Figura 1.34 - Módulo de elasticidade em função da relação cimento/água de concretos convencionais e reciclados (adaptado de BUILDING CONTRACTORS SOCIETY OF JAPAN, 1978 apud ACI, 2001)

No estudo de Springenschmid e Sodeikat (1998) citado anteriormente, foi observado que o módulo de elasticidade decresce com o aumento no teor de agregados reciclados, o que ocorreu devido à menor rigidez dos agregados reciclados em relação aos naturais. Na Figura 1.35 são ilustrados esses resultados (referir-se à Figura 1.28 para identificar os concretos). 


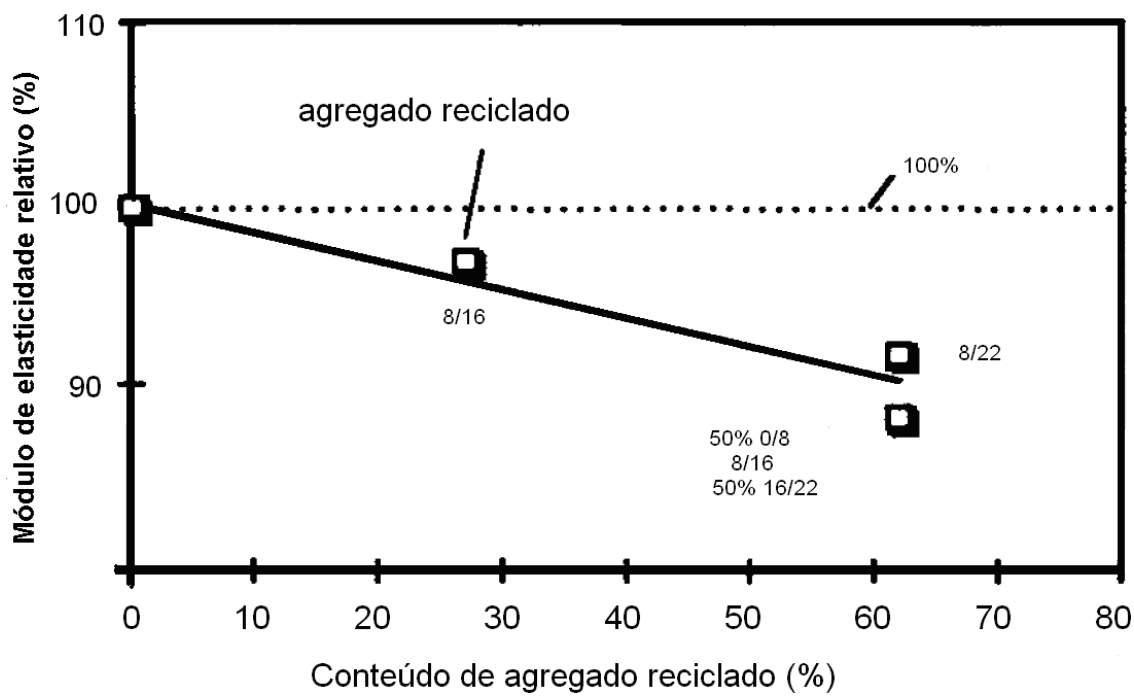

Figura 1.35 - Módulo de Elasticidade normalizado com o módulo de Young do concreto de referência R0 (adaptado de SPRINGENSCHMID e SODEIKAT, 1998)

Segundo estudo de Bairagi et al. (1993) a relação entre o módulo de elasticidade e a resistência à compressão de concretos com diferentes teores de substituição de agregados graúdos pode ser descrita pela eq.(4) e eq.(5).

$$
\begin{gathered}
E=\alpha \sqrt{f_{c}} ;(0 \leq r \leq 1,0) \\
\alpha=\alpha(r)=(5780-1340 . r)
\end{gathered}
$$

onde:

E: módulo de elasticidade (MPa)

$\mathrm{f}_{\mathrm{c}}$ : resistência à compressão $(\mathrm{MPa})$

r: teor de substituição de agregados graúdos naturais por reciclados

Existem ainda diversos outros estudos que apresentam uma relação entre o módulo de elasticidade e a resistência à compressão do concreto reciclado. Ravindrarajah (1987) apud Juan (2004), por exemplo, relaciona as duas propriedades, no caso de substituição em 100\%, através das seguintes equações:

$$
\begin{aligned}
& E_{e}=4,63 \cdot f_{c}^{0,5} \\
& E_{d}=6,19 \cdot f_{c}^{0,5}
\end{aligned}
$$

onde: 
$\mathrm{E}_{\mathrm{e}}$ : módulo de elasticidade estático (GPa)

$\mathrm{E}_{\mathrm{d}}$ : módulo de elasticidade dinâmico (GPa)

$\mathrm{F}_{\mathrm{c}}$ : resistência à compressão $(\mathrm{MPa})$

\subsubsection{Relação água/cimento}

Juan (2004) observou nos dados encontrados na literatura que a relação a/c efetiva no concreto contendo agregados reciclados para que se obtenha a mesma resistência que o concreto convencional é um pouco menor, como apresentado na Figura 1.36.

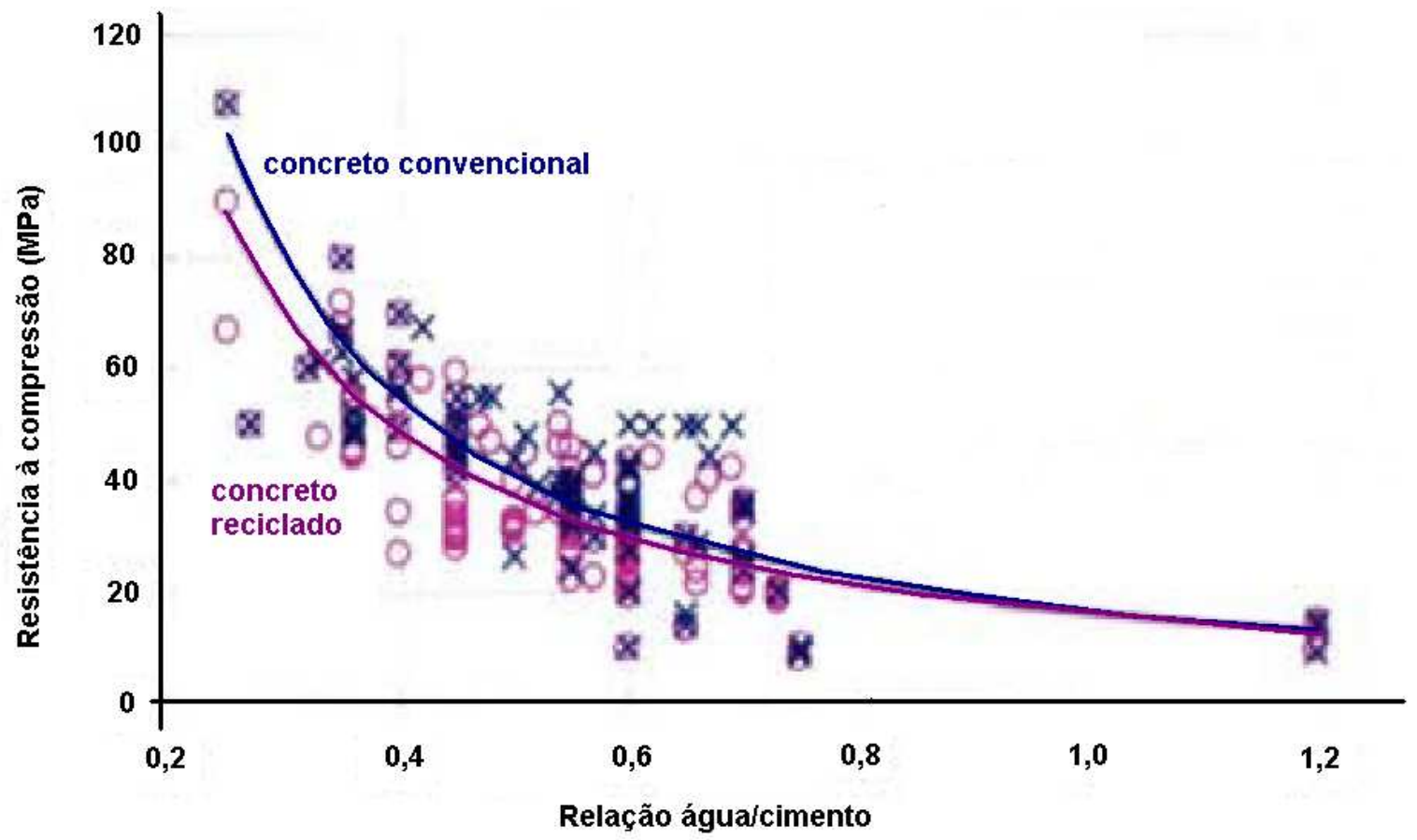

Figura 1.36 - Relação entre a resistência à compressão e a relação a/c no concreto convencional e no concreto reciclado (adaptado de JUAN, 2004)

Haja vista a grande variabilidade da absorção dos agregados e dos métodos de mistura utilizados é difícil determinar com precisão a quantidade de água que é absorvida pelos agregados, a água superficial no agregado e a água que fica na pasta de cimento.

Observa-se que as curvas de Abrams são distintas, pois as características dos agregados utilizados são diferentes. Com a utilização de agregados reciclados, para 
uma mesma relação a/c, geralmente é necessário um maior consumo de cimento para se obter certa resistência à compressão.

\subsubsection{Resistência à fadiga}

Kobayashi e Hamada (2007) fizeram ensaios de fadiga por flexão do concreto em corpos de prova produzidos com agregados naturais e agregados reciclados de qualidades distintas (diferentes quantidades de pasta aderida). Seus experimentos mostraram que quanto maior a quantidade de pasta aderida aos agregados, pior é o desempenho do concreto quanto à fadiga. Entretanto, isso não impede que o material reciclado seja utilizado em revestimento de pavimento, desde que a pasta aderida seja retirada em proporções adequadas para seu uso.

\subsubsection{Resistência à fratura}

A resistência à fratura é importante porque descreve como ocorre a propagação de fissuras no material, sendo caracterizada pela tenacidade à fratura $\left(\mathrm{K}_{\mathrm{C}}\right)$, pela abertura da ponta da trinca (CTOD-crack tip opening displacement) e pela energia total de fratura $\left(\mathrm{G}_{\mathrm{F}}\right)$. Somente a medida de resistência à compressão e de resistência à tração do concreto não garante seu desempenho. Concretos com qualidades variadas podem ter comportamentos semelhantes quanto à resistência à compressão e à tração e, no entanto, apresentar desempenhos estruturais distintos (Cervantes et al., 2007).

Cervantes et al. (2007) observaram que o CTOD, na ruptura, foi menor para o concreto com agregados naturais se comparado àquele com agregados graúdos reciclados. A energia total de fratura $\left(G_{F}\right)$, para o caso do concreto convencional, foi aproximadamente duas vezes maior que para o concreto com reciclados, enquanto a tenacidade à fratura foi somente $20 \%$ maior.

\subsubsection{Porosidade}

A porosidade do concreto é uma propriedade chave, pois influencia tanto suas características mecânicas como sua durabilidade. O volume total de poros no 
concreto reciclado, principalmente poros grandes (>100nm) aumenta conforme se aumenta o teor de substituição de agregados. Gómez-Soberón (2002) relata, ao substituir totalmente os agregados graúdos naturais por reciclados, um aumento no volume de poros de 5,9\% aos 7 dias, de 2,3\% aos 28 dias e 3,8\% aos 90 dias. 0 decréscimo no volume total de poros com a idade do concreto ocorre devido à cristalização de novos produtos, reduzindo tanto o número como o tamanho dos poros. A faixa mais afetada é aquela de raio menor que $30 \mathrm{~nm}$ (zona em que se encontra a maior porcentagem de volume de poros), que são geralmente associados à sua capacidade de influenciar na resistência, permeabilidade e retração do concreto (JOHN et al., 1998).

Além do teor de substituição de agregados, a porosidade média do agregado utilizado também aumenta significativamente a porosidade média no concreto, considerando uma mesma relação a/c, e mesmo consumo de cimento (ANGULO, 2005). Em estudo comparando características de concretos confeccionados com agregados reciclados de RCD de diferentes faixas densitárias, Angulo (2005) observou que para concretos obtidos com agregados graúdos de massa específica aparente maior que $2,2 \mathrm{~g} / \mathrm{cm}^{3}$ e areia natural, a absorção de água permanecia inferior a $8 \%$, valor considerado como sendo de um concreto durável segundo classificação de Helene (1983) apud Carrijo (2005).

\subsubsection{Absorção e permeabilidade}

A absorção e permeabilidade de concretos feitos com agregados reciclados são maiores do que em concretos convencionais, já que essas características estão diretamente ligadas à porosidade do material. Com o uso de agregados reciclados, além da zona de transição entre agregado natural e argamassa aderida, cria-se mais uma zona de transição entre o agregado reciclado e a nova argamassa, que também contribui para o aumento da porosidade no novo concreto (CARRIJO, 2005).

Gonçalves et al. (2007) mostraram que a substituição de agregados miúdos naturais por reciclados em $50 \%$ promove um incremento na absorção dos concretos independente da relação a/c utilizada. Os autores encontraram, para concretos com 
substituição de $50 \%$ e relação a/c de 0,50; 0,65 e 0,80, incrementos na absorção de 41,63\%; 4,83\% e 13,03\% respectivamente. Lopez-Gayarre et al. (2009) relatam aumentos na absorção de até $50 \%$, sendo que mesmo para teores de substituição baixos (20\%) o aumento na absorção de água já é significativo (24,6\%).

Zaharieva et al. (2003) encontraram valores de permeabilidade à água e ao ar duas vezes maiores no caso de concreto com agregados reciclados quando comparados à concretos convencionais. Em relação à permeabilidade de superfície, os autores encontraram valores entre 10 e 15 vezes maiores no caso dos reciclados. A razão principal para isso, segundo os autores, foi a maior relação a/c utilizada, pois apesar de inicialmente a água ser absorvida pelos agregados reciclados, depois ela é gradualmente transferida para a mistura resultando em maior porosidade da pasta.

Porém, ao contrário da tendência observada pela maioria dos autores, o concreto reciclado do pavimento da rodovia l-10 no Texas apresentou baixa permeabilidade. Uma das possíveis explicações para tal é o fato de o concreto ter apresentado ausência de micro-rachaduras devido ao fato de ter uma natureza mais elástica. Isto é, o menor módulo de elasticidade do concreto permitiria maior acomodação de deformações e menor concentração de tensões no concreto, diminuindo a quantidade de micro-rachaduras nas placas (ACPA, 2009).

\subsubsection{Carbonatação}

Como a permeabilidade do concreto contendo agregados reciclados é maior, a carbonatação deste é mais rápida (ZAHARIEVA et al., 2003). Algumas pesquisas indicam carbonatação em concretos contendo agregados reciclados derivados de concreto carbonatado até $65 \%$ superiores às encontradas em concretos convencionais (ACPA, 2009).

Evangelista e Brito (2006) estudaram o comportamento do concreto frente a carbonatação quando o agregado miúdo é substituído pelo agregado reciclado em proporções de $30 \%$ e $100 \%$, e observaram que a profundidade de carbonatação aumenta linearmente com o teor de substituição do agregado. A relação entre o teor de substituição e a profundidade de carbonatação encontrada pelo ensaio proposto 
pela especificação E391 proposta pelo Laboratório Nacional de Engenharia Civil de Portugal (LNEC, 1993) é ilustrada na Figura 1.37.

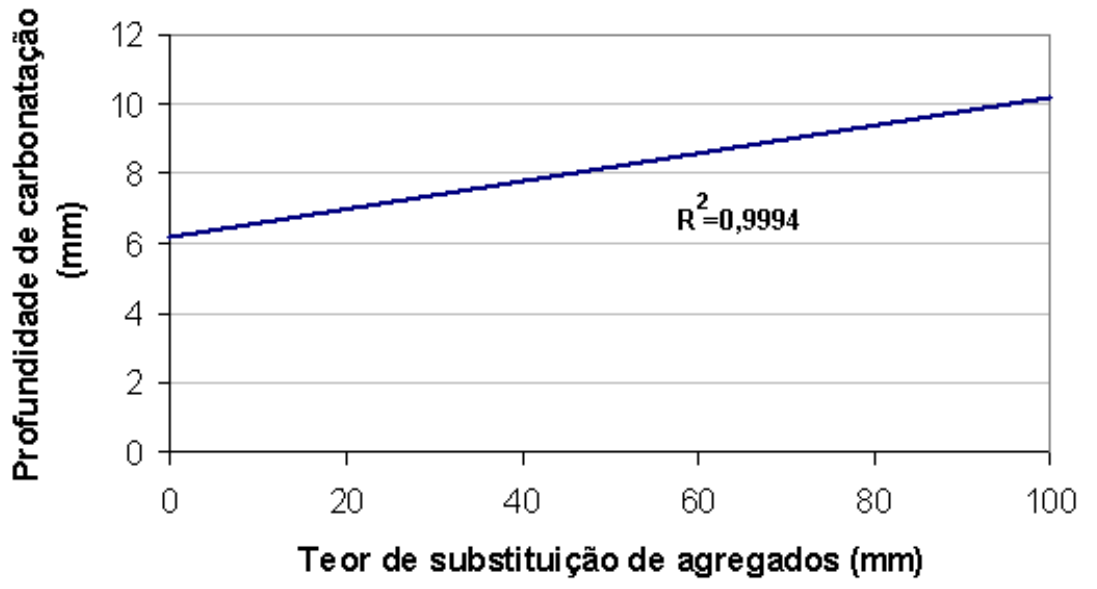

Figura 1.37 - Relação entre a profundidade de carbonatação aos 91 dias e o teor de substituição de agregados miúdos naturais por reciclados (adaptado de EVANGELISTA e BRITO, 2006)

Em vista dos resultados obtidos, os autores concluem que por questões de durabilidade a substituição total dos agregados pode representar sérias dificuldades; contudo, é perfeitamente possível se adotar quantidades menores de substituição. Em pavimentos de concreto, entretanto, não há relatos conhecidos de problemas ligados à carbonatação do concreto.

\subsubsection{Reação álcali-sílica}

A utilização de pavimentos de concreto antigos apresentando reação álcali-sílica como matéria prima para produção de agregados reciclados para novos pavimentos é uma prática largamente desencorajada (VANCURA et al., 2009), pois o potencial de ocorrência de reação álcali-sílica nos concretos contendo agregados reciclados é influenciado pelo teor alcalino tanto do novo quanto do antigo concreto (STARK, 1996 apud ACPA, 2009). Todavia, mesmo utilizando agregados reciclados altamente reativos, é possível reduzir o potencial de reação álcali-sílica a níveis que possibilitem o seu uso com segurança.

Algumas técnicas propostas pela ACPA (2009) são: o emprego de cinza volante e cimento com escória, a adição de nitrato de lítio e a limitação da quantidade de agregados miúdos reciclados. A utilização de escória torna o concreto menos 
permeável, diminuindo o risco de ocorrer reação álcali-agregado (JUAN, 2004). A cinza volante, além de aumentar a resistência do concreto, diminuir o potencial de desenvolvimento de trincas de retração e diminuir a permeabilidade do concreto, diminui seu $\mathrm{pH}$, tornando-o menos suscetível à ocorrência de reação álcali-sílica. Já o mecanismo de ação de compostos de lítio na mitigação da reação expansiva álcali-sílica não é bem compreendido, sendo que algumas das explicações propostas são: a) o lítio altera o produto da reação álcali-sílica resultando em um produto menos expansivo; b) o lítio reduz a dissolução de sílica; c) o lítio diminui a repolimerização de sílica e silicatos (FHWA, 2003).

Outro fator a ser considerado ao se analisar a potencialidade de ocorrência de reação álcali-sílica no concreto contendo agregados reciclados é a forma do agregado reciclado utilizado. Como já comentado, o método de britagem utilizado pode alterar significativamente sua forma em relação à forma do agregado natural, e segundo Valduga et al. (2005), isso afeta significativamente o potencial de reações expansivas no concreto.

\subsubsection{Resistência aos sulfatos}

Não existem muitos estudos sobre a resistência de concretos contendo agregados reciclados ao ataque por sulfatos. Porém, haja vista a maior permeabilidade deste e ao conteúdo de sulfatos presentes na pasta de cimento aderida aos agregados (JUAN e GUTIÉRREZ, 2009), é esperado que o desempenho quanto à resistência aos sulfatos seja inferior no caso do concreto reciclado.

\subsubsection{Resistência à penetração de íons cloro}

A resistência à penetração de íons cloro diminui com o aumento do teor de substituição de agregados naturais por reciclados (KOU et al., 2007). Isso ocorre devido à maior permeabilidade do concreto reciclado. Contudo, para concretos reciclados de alta resistência, ajustando-se a quantidade de cimento para obtenção da resistência desejada, essa tendência não é observada. (LIMBACHIYA et al., 2000) 


\subsubsection{Resistência ao gelo/degelo}

Salem e Burdette (1998) observaram, através de ensaios, que a resistência ao gelo/degelo do concreto contendo agregados reciclados é reduzida, o que seria explicado pela saturação do agregado durante o ensaio de resistência ao gelo/degelo.

Springenschmid e Sodeikat (1998), por sua vez, afirmam que a resistência do concreto contendo agregados reciclados ao gelo/degelo é alta desde que estes sejam utilizados somente com dimensões superiores a $4 \mathrm{~mm}$. $\mathrm{O}$ uso de agregados miúdos reciclados ocasionaria, segundo os autores, grande perda de massa em ensaios de gelo/degelo, devido à maior quantidade de pasta de cimento presente nessa fração dos agregados reciclados.

Entretanto, Eickschen e Siebel (1998) mostraram através do uso de agregados reciclados em todas as frações, inclusive agregados miúdos, que independentemente do teor de areia reciclada utilizado, a perda de massa durante 0 ensaio de resistência ao gelo/degelo permanece bem abaixo do limite máximo estipulado (5\%). Assim sendo, a resistência ao gelo/degelo não limita o uso de agregados miúdos reciclados.

A alta resistência do concreto contendo agregados graúdos reciclados ao gelo/degelo teria sido confirmada em campo na rodovia alemã Autobahn A93 na Bavária, na qual com o emprego de $100 \%$ de agregados reciclados de dimensão maiores que $4 \mathrm{~mm}$ e já tendo sido exposta a gelo/degelo e a sais para descongelamento, não apresentou nenhuma deterioração (SPRINGENSCHMID e SODEIKAT, 1998).

\subsubsection{Retração, fluência e coeficiente de expansão térmica}

Quanto ao aumento da fluência e da retração nos concretos reciclados, a princípio é importante reconhecer que já se observou que sua rigidez é diminuída em relação a concretos com agregados virgens (CUTTELL et al. 1997). A retração é dependente da quantidade de argamassa remanescente nos agregados reciclados; como a 
absorção de água aumenta e a massa específica aparente dos grãos diminui com o aumento da quantidade de argamassa antiga nos agregados, a rigidez (módulo de elasticidade) dos agregados consequentemente diminui, oferecendo menos resistência à retração. A retração, portanto, aumenta com a diminuição do módulo de elasticidade dos agregados. (BIJEN, 1996; de VRIES, 1996; SRINGENSCHMID e SODEIKAT, 1998; GÓMEZ-SOBERÓN, 2002; JUAN, 2004; KOU et al., 2007; YANG et al., 2008; BALBO, 2009).

Outro fator que influi na diminuição da fluência e da retração é o tempo de cura. $A$ redução da porosidade do concreto reciclado sob efeito da cristalização de produtos de hidratação dos ligantes hidráulicos reduz, evidentemente, o número de poros e seu tamanho nessas misturas (GÓMEZ-SOBERÓN, 2002).

Segundo o Building Contractor's Society of Japan (1978) apud ACI (2001) foram encontrados valores de retração $20 \%$ a $50 \%$ maiores em concretos feitos com agregados graúdos reciclados e miúdos naturais se comparados ao concreto convencional. Ao se utilizarem tanto graúdos como miúdos reciclados, a retração aumentou para $70 \%$ a $100 \%$ maiores que os convencionais. O aumento da retração de secagem pode ser explicado por uma maior relação a/c necessária quando são empregados agregados reciclados.

YANG et al. (2008) observaram que a retração inicial dos concretos convencionais era maior que aquela dos concretos reciclados, todavia, após dez dias a retração dos primeiros decresce rapidamente enquanto aquela dos concretos reciclados decresce mais lentamente.

Em estudo feito somente com substituição da fração miúda por agregados reciclados, foi observado que houve um aumento de mais de $40 \%$ na retração de secagem do concreto contendo agregado reciclado em relação ao convencional (RAVINDRARAJAH e TAM, 1987).

No que se refere à fluência, segundo valores encontrados na literatura (HANSEN, 1986 apud $\mathrm{ACl}, 2001)$, concretos reciclados apresentam valores $30 \%$ a $60 \%$ superiores a concretos convencionais. Esse comportamento é explicado pela maior 
quantidade de pasta presente, já que esta é diretamente relacionada com o módulo de elasticidade e a fluência do concreto ( $\mathrm{ACl}, 2001)$.

Em relação ao coeficiente de expansão térmica, Cuttell et al. (1997), em estudo com 16 seções de pavimento de concreto, relataram que a média dos coeficientes de expansão térmica encontrados para seções contendo agregados reciclados era maior que aquela das amostras de controle. Esse fato, segundo os autores, é explicado pela menor quantidade de agregados naturais presentes no concreto, os quais suportam menos restrições à expansão volumétrica em resposta às flutuações de temperatura e umidade. Valores esperados de coeficientes de expansão térmica no caso de concretos reciclados são $10 \%$ superiores aos valores de concretos convencionais (WADE et al., 1997 apud ACPA, 2009).

O diferencial térmico devido à variação da temperatura ambiente é a causa primária da retração e expansão do concreto contendo agregados reciclados; sendo que outras fontes de retração tais como gradiente hídrico e carbonatação são secundárias se comparadas ao gradiente térmico (VANCURA et al., 2009; HUBER et al., 2004 apud VANCURA et al., 2009).

Nos pavimentos de concreto é essencial que haja um controle da retração e da fluência, pois os diferenciais térmicos entre topo e fundo da placa de concreto podem ocasionar empenamento das placas, e, consequentemente, tensões elevadas, levando a trincas e resultando em um decréscimo da capacidade de transferência de carga nas juntas e deterioração do pavimento (VANCURA et al., 2009).

Além disso, os pavimentos de concreto podem perder umidade rapidamente no topo e absorver água pela parte inferior durante um longo período de tempo, levando à ocorrência de retração no topo e inchamento na parte inferior das placas, e, novamente, ao empenamento e aparecimento de tensões indesejáveis. A presença de agregados reciclados, neste caso, é indesejável, pois por possuírem menor rigidez, levam a um maior inchamento e retração do concreto devido às condições de umidade. Springenschmid e Sodeikat (1998) relataram, simulando condições de empenamento em laboratório, que a flecha registrada ao se utilizar agregados 
reciclados em teores de $62 \%$ em peso, foi o dobro daquela observada em concreto convencional. Portanto é imprescindível que as condições de drenagem do pavimento de concreto reciclado sejam eficientes (SPRINGENSCHMID e SODEIKAT, 1998).

\subsubsection{Resistência à abrasão}

O concreto reciclado, se comparado a um concreto de controle, apresentará menor resistência à abrasão por erosão. Essa queda na resistência á mais acentuada conforme se aumenta o teor de substituição de agregados graúdos na mistura, não sendo significativa quando este teor é inferior a 50\% (DHIR et al., 1999 apud JUAN, 2004).

Entretanto, para concretos reciclados de alta resistência (com ajuste na quantidade de cimento para obtenção da resistência desejada) observa-se que o teor de substituição de agregados naturais por reciclados não altera significativamente a resistência à abrasão do concreto (LIMBACHIYA et al., 2000).

\subsection{DOSAGEM DO CONCRETO CONTENDO AGREGADOS RECICLADOS}

\subsubsection{Adição de sílica ativa e cinza volante}

A adição de sílica ativa e cinza volante como aditivos no concreto contendo agregados reciclados é uma prática bastante comum, tendo-se mostrado eficaz para manter a resistência mecânica do concreto reciclado em níveis comparáveis ao do concreto produzido com agregados naturais (SANI et al., 2005; WERNER, 1994; YANG et al., 2008).

A adição de cinza volante induz o acréscimo da quantidade de microporos em detrimento da quantidade de macro e mesoporos. Ela reduz a exsudação por parte dos agregados reciclados, melhorando, portanto, a zona de interface entre os agregados e a nova pasta de cimento. Isso ocorre, pois a baixa massa específica 
aparente e alta área específica da cinza volante permitem que esta retenha mais água e bloqueie os canais de exsudação da água (CORINALDESI et al., 2001 apud SANI et al., 2005; POON et al., 2007).

Para concretos contendo agregados reciclados misturados em condição de umidade ambiente e compensando em 100\% a absorção de água, Poon et al. (2007) observaram que somente com a substituição dos agregados naturais graúdos pelos reciclados em 100\% houve uma queda de 14\% na resistência à compressão aos 90 dias, enquanto que com a substituição de $25 \%$ do cimento por cinza volante a queda foi somente de $5 \%$.

Além disso, os mesmos autores observaram que a adição da cinza volante melhora as condições de trabalhabilidade do concreto: maior abatimento inicial e menor perda de trabalhabilidade com o tempo.

Ravindrarajah e Tam (1987) observaram que ao substituir 10\% dos agregados miúdos reciclados por cinza volante em concretos com substituição total de agregados miúdos, melhora o desempenho do concreto em relação à resistência mecânica, ao módulo de elasticidade, e à fluência, reduzindo os efeitos negativos advindos da substituição de agregados naturais por reciclados.

A sílica ativa, por sua vez, reage com o hidróxido de cálcio formando mais silicatos hidratados de cálcio e proporcionando altas resistências. Além disso, a sílica ativa pode agir como fíler, preenchendo os vazios dentro do agregado reciclado, levando a formação de uma zona de transição menos porosa e a um melhor intertravamento pasta-agregado (TAM et al., 2008).

\subsubsection{Adição de fibras}

Cervantes et al. (2007) analisaram o uso de fibras sintéticas para melhorar as características dos concretos contendo agregados graúdos reciclados e observaram que a adição de fibras aumenta a energia total de fratura. $O$ concreto obtido com a adição de fibras apresentou desempenho similar ao concreto produzido com agregados naturais. A adição de $1,78 \mathrm{~kg} / \mathrm{m}^{3}$ de fibras levou a uma energia total de 
fratura aos $4 \mathrm{~mm}$ de CMOD aproximadamente 3,2 vezes maior se comparado ao concreto reciclado sem a adição de fibras. Esse fenômeno ocorre, pois as fibras provocam um efeito de tenacificação no rastro da trinca, aumentando a energia residual de deformação e a ligação dos grãos - Figura 1.38 (SAKAI, 1987).

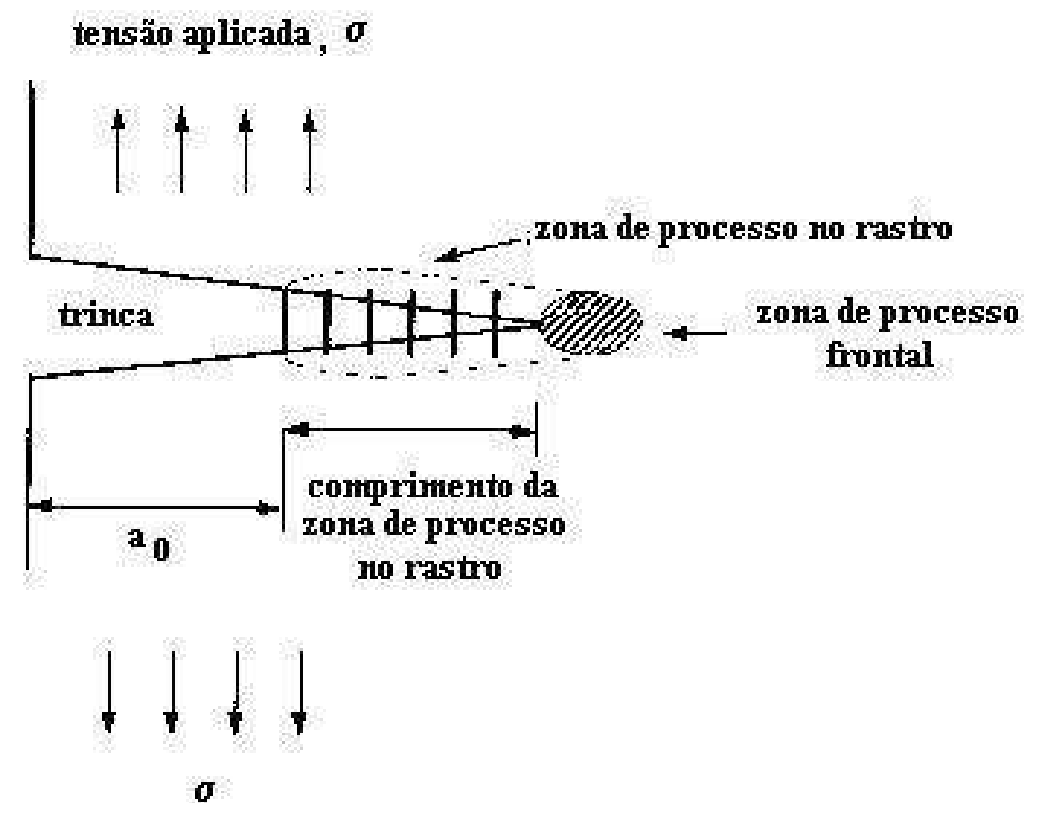

Figura 1.38 - Zona frontal do processo e zona de processo de rastro (adaptado de SAKAI, 1987)

\subsubsection{Cura}

O uso de agregados miúdos reciclados faz com que o concreto seja menos afetado por uma cura rápida. Isso ocorre, pois a água que é inicialmente absorvida pela areia é gradualmente transferida à pasta de cimento compensando a perda de água durante a hidratação (ZAHARIEVA et al., 2003).

\subsubsection{Dosagem}

A dosagem do concreto contendo agregados reciclados é realizada, na maioria dos casos, da mesma maneira que a do concreto tradicional. Entretanto, algumas medidas são geralmente levadas em conta, tais como: a) a adição de água para compensar a quantidade que será absorvida pelos agregados; b) a adição de cinza volante e de plastificantes; c) a pré-molhagem dos agregados, que, na dosagem convencional, é geralmente desprezada, além de ser uma medida difícil de se adotar em campo. 
Para considerar tal efeito dos agregados reciclados na dosagem dos concretos, existem coeficientes de correção utilizados na dosagem de concretos reciclados que dependem da porcentagem de agregado reciclado utilizado e da categoria resistente do concreto (JUAN, 2004).

Para o método de Abrams, por exemplo, tem-se:

$$
f_{C}=A \cdot B^{-(a / c)}
$$

onde:

a/c: relação água/cimento em peso

$\mathrm{f}_{\mathrm{C}}$ : resistência à compressão

A: constante que depende do tipo de agregado

B: constante que depende do tipo de cimento

Para aplicar o fator de correção $r$ deve-se igualar a relação $a / c$ efetiva para 0 concreto convencional e para o concreto reciclado conforme se segue:

$$
\begin{gathered}
f_{c r}=A_{r} \cdot B_{r}^{-(a / c)} \\
f_{c c}=A_{c} \cdot B_{c}^{-(a / c)} \\
\frac{f_{c r}}{f_{c c}}=r=\frac{A_{r}}{A_{c}} \cdot\left[\frac{B_{r}}{B_{c}}\right]^{-(a / c)}=\frac{A_{r}}{A_{c}}
\end{gathered}
$$

onde:

$\mathrm{f}_{\mathrm{cr}}$ : resistência à compressão do concreto reciclado

$\mathrm{f}_{\mathrm{cc}}$ : resistência à compressão do concreto convencional

Portanto, a equação de Abrams se apresentaria da seguinte forma:

$$
f_{C}=A \cdot r \cdot B^{-(a / c)}
$$


onde:

r: coeficiente de redução da resistência do concreto reciclado em função da resistência do concreto convencional

Como a tendência mais observada na literatura é que a resistência do concreto decresça com o aumento do teor de substituição de agregados naturais por reciclados, o valor de "r" é menor para concretos com maiores teores de substituição. Quando o valor de resistência à compressão desejada aumenta "r" também diminui, pois como visto na literatura, quanto maior a classe de resistência do concreto, maiores são as diferenças observadas ao se substituir os agregados.

Estudo realizado por Juan e Gutiérrez (2004) resultou nos valores de "r" em função do teor de substituição dos agregados e da resistência à compressão conforme apresentados na Figura 1.39. Para se obter, por exemplo, um concreto de $30 \mathrm{MPa}$ de resistência, com substituição total dos agregados graúdos, a dosagem convencional a ser utilizada é aquela para 35MPa $(30 / 0,88=35 \mathrm{MPa})$.

Angulo (2005) mostra a Lei de Abrams, que correlaciona a resistência do concreto com a relação a/c através de uma função exponencial, só é valida quando mantida a porosidade do agregado. Para substituição total de agregados graúdos com diferentes faixas densitárias, o autor obteve as curvas apresentadas na Figura 1.40.

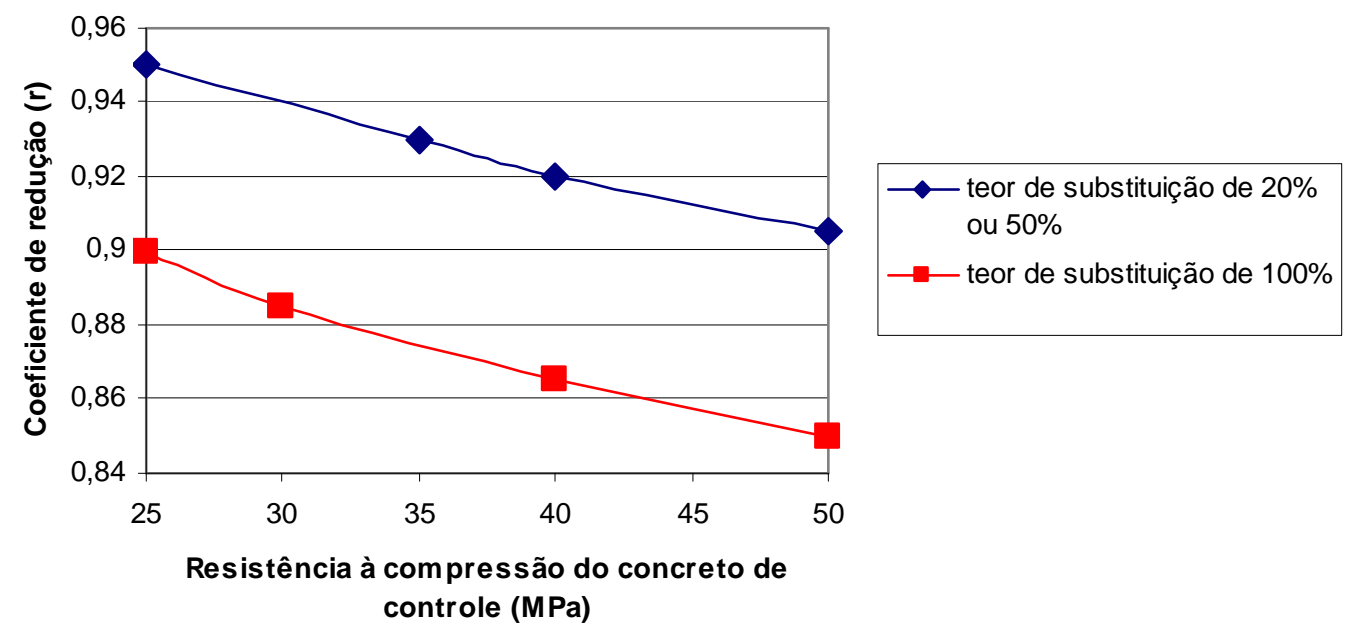

Figura 1.39 - Coeficientes de redução para o a resistência à compressão do concreto reciclado (adaptado de JUAN e GUTIÉRREZ, 2004) 


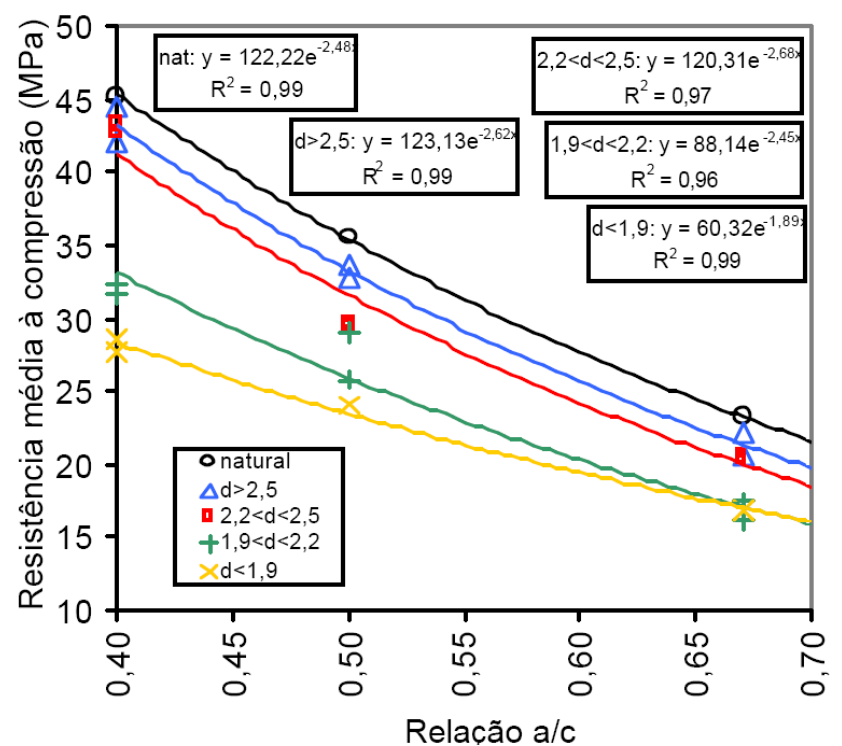

Figura 1.40 - Resistência média à compressão dos concretos em função da relação a/c (ANGULO, 2005)

Pode-se notar, a partir da figura anterior, que concretos de maiores resistências aparentam ser mais susceptíveis à variação de massa específica aparente dos agregados utilizados. Segundo Carrijo (2005) isso se deve ao fato de que para o concreto com baixa relação a/c o agregado reciclado se torna o elo mais fraco, limitando a resistência do concreto. Observa-se que para altas relações a/c as curvas convergem chegando a se cruzar; portanto, a correção da curva não poderia ser feita através dos coeficientes de redução 'r' propostos por Juan e Gutierrez (2004).

Esse comportamento é mais acentuado no estudo de Leite (2001), em que a autora substituiu não só agregados graúdos naturais por reciclados, mas também miúdos. As curvas relacionando a resistência à compressão e a relação $a / c$ obtidas pela autora são apresentadas na Figura 1.41, em que AMR são agregados miúdos reciclados e AGR agregados graúdos reciclados: 


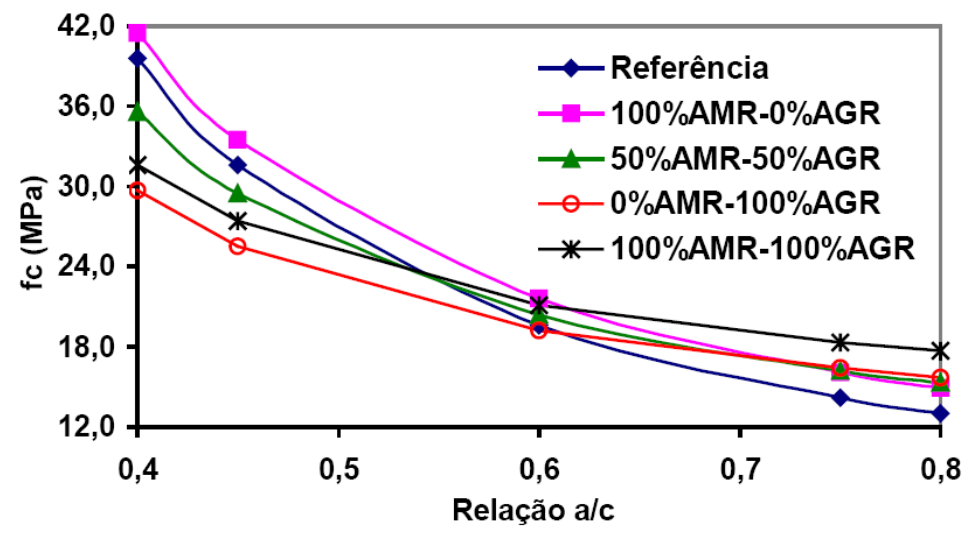

Figura 1.41 - Resistência média à compressão dos concretos em função da relação a/c (LEITE, 2001)

Observa-se neste caso que até para relações a/c menores que 0,6 as curvas se cruzam, e, portanto, os coeficientes de redução ' $r$ ' propostos por Juan e Gutierrez (2004) também não seriam válidos neste caso.

Vale ressaltar também que as curvas de dosagem encontradas na literatura indicam que geralmente há um aumento do consumo de cimento com o uso de agregados reciclados para que se obtenha a mesma resistência. Esse fator deve ser investigado com maior cuidado, pois o ganho ambiental e financeiro obtido com a reutilização de material pode não ser compensado pelo maior consumo de cimento em alguns casos.

Levy (2001) explica que o maior travamento entre os agregados reciclados devido ao seu formato implica em maior demanda de pasta de cimento que funciona como lubrificante para manter a consistência especificada

\subsubsection{Teor de ar incorporado}

O teor de ar incorporado nos concretos com agregado reciclado é geralmente $0,6 \%$ superior e levemente mais variável do que o teor de ar incorporado em concretos frescos convencionais (VANDENBOSSCHE e SNYDER, 1993 apud ACPA, 2009). Isso ocorre devido à quantidade de ar que fica retida na pasta aderida aos agregados reciclados (WADE et al., 1997 apud ACPA, 2009), Quando o agregado é adicionado à mistura em estado saturado, contudo, não há diferença no teor de ar 
incorporado do concreto reciclado se comparado ao concreto convencional (JUAN e GUTIÉRREZ, 2004).

\subsubsection{Mistura}

O processo de mistura é determinante nas características do concreto contendo agregados reciclados tanto no seu estado fresco como endurecido, pois determina as interações de superfícies dos constituintes do concreto. A quantidade de água absorvida pelos agregados reciclados durante a mistura depende da ordem de mistura dos componentes do concreto, da fluidez da pasta e da absorção dos agregados (BARRA, 1997).

A relação entre a quantidade de água que o agregado é capaz de absorver do concreto fresco desde a mistura até sua aplicação, e a massa do agregado seco; é definida por Barra (1997) como sendo o coeficiente de absorção efetivo, dado pela equação:

$$
A_{e}=\frac{M_{f}-M}{M_{s}} .100
$$

onde:

$A_{e}:$ coeficiente de absorção efetivo

$\mathrm{M}_{\mathrm{f}}$ : massa do agregado depois de estar submerso no concreto fresco

M: massa do agregado com o teor de umidade em que é empregado na preparação do concreto

$\mathrm{M}_{\mathrm{S}}$ : massa do agregado no estado seco

Barra (1997) descreve dois processos possíveis de mistura. No primeiro mistura-se o agregado graúdo reciclado previamente com a água, para depois ser adicionado o cimento e a areia. Nesse processo o agregado absorve inicialmente grande quantidade de água podendo saturar-se ou não. Com a adição de cimento a água aderida à superfície dos agregados provoca uma concentração maior da pasta de cimento ao redor deste, favorecendo a aderência entre pasta e agregado. Entretanto, se houver uma migração da água no fluxo contrário (do agregado para a pasta) antes da pega, a saída da água representará um aumento da relação a/c, e, 
portanto, da porosidade ao redor do agregado, enfraquecendo essa zona de interface no concreto. Se esse fluxo migratório contrário ocorrer após a pega, a água proporciona uma cura interna ajudando na melhoria da aderência. Se os agregados forem usados em condição de saturação a probabilidade de que o fluxo de água do agregado para a pasta ocorra antes da cura é maior.

O segundo processo descrito pela autora é a mistura inicial da pasta ou da argamassa e posteriormente a adição do agregado graúdo. Quando o agregado é inserido em condição saturada, a água presente nos poros superficiais aumenta a relação a/c da pasta ao redor do agregado reduzindo a qualidade da zona de interface. Se o agregado for inserido em condição seca, podem ocorrer duas situações: a redução da relação a/c ao redor do agregado melhora a aderência pasta-agregado; ou essa redução é tal que falta água para hidratação ao redor do agregado, prejudicando a aderência pasta-agregado.

Tam et al. (2005) e Tam et al. (2007) propuseram o método TSMA (Two-Stage Mixing Approach) de mistura do concreto visando melhorar sua resistência para o caso do uso de agregados reciclados. O método consiste em dividir o processo em duas etapas de mistura. Na primeira etapa são misturados somente os agregados (miúdos e graúdos), o cimento e metade da quantidade total de água, a fim de que ocorra a formação de uma fina camada de pasta de cimento na superfície do agregado reciclado, a qual penetra no interior dos poros da antiga pasta de cimento preenchendo as rachaduras e vazios. Na segunda etapa, a água restante é adicionada para completar o processo de hidratação do cimento. Dessa maneira uma maior resistência é desenvolvida na zona interfacial (zona supostamente mais fraca) colaborando, consequentemente, para um aumento da resistência mecânica do concreto. Os métodos comparados pelos autores em seus trabalhos estão esquematizados na Figura 1.42. 

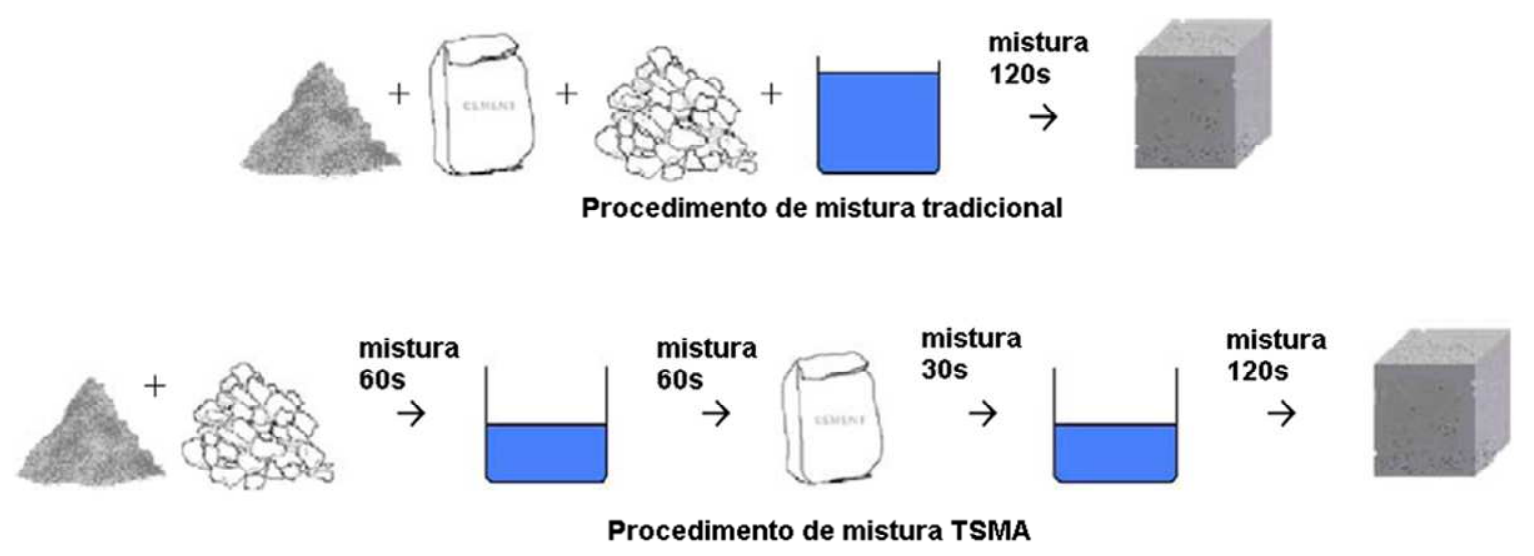

Figura 1.42 - Procedimentos de mistura comparados por Tam et al. (2005)

Os autores observaram que para teores de substituição de agregados variando entre $0 \%$ e $100 \%$, o método de mistura proposto resultou em melhores propriedades do concreto em estado endurecido (resistência à compressão, resistência à flexão e módulo de elasticidade). As Figuras 1.43 a 1.45 ilustram os resultados obtidos pelos autores, utilizando os dois métodos de mistura, para a resistência à compressão, a resistência à tração na flexão, e a massa específica aos 28 dias.

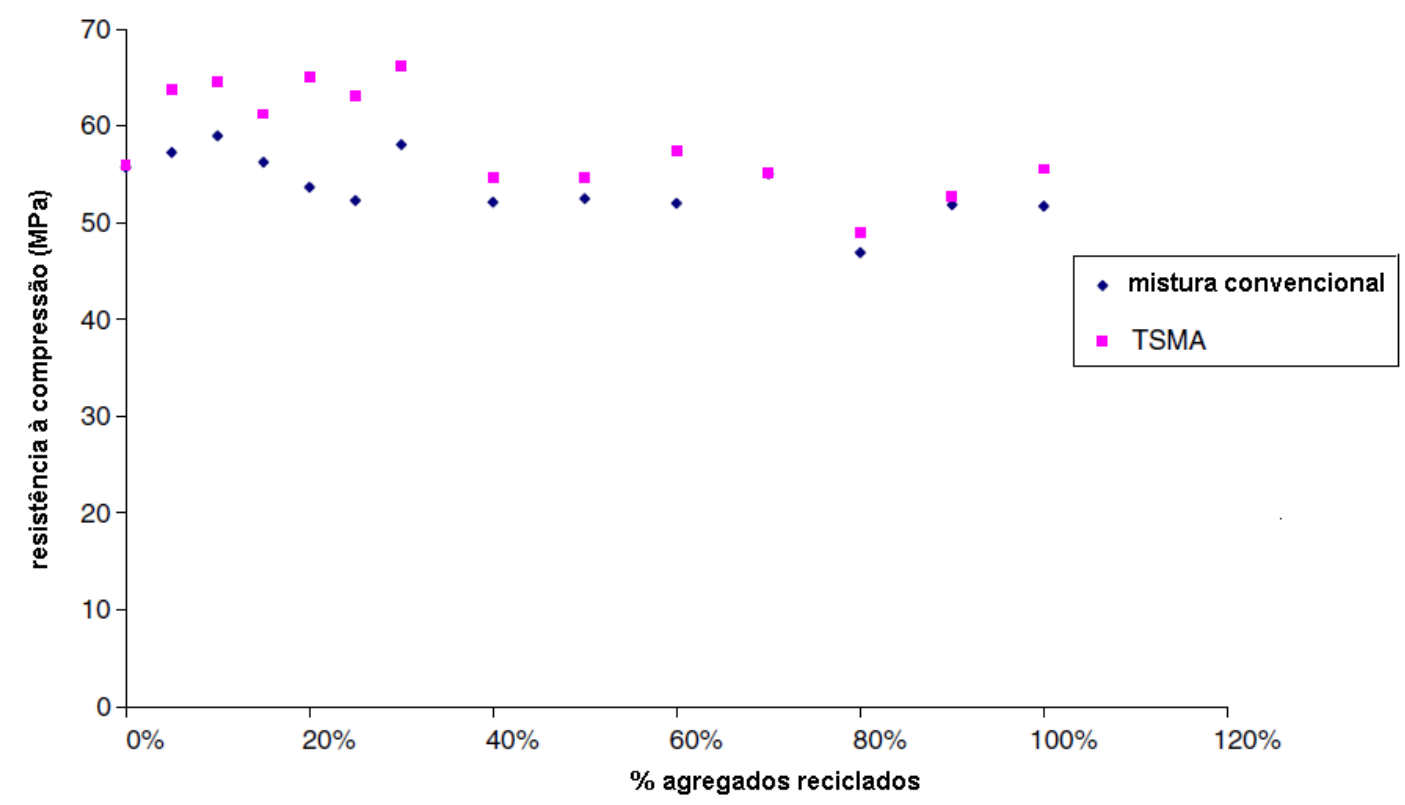

Figura 1.43 - Resistência à compressão aos 28 dias para diferentes teores de substituição dos agregados utilizando o método tradicional de mistura e o método TSMA (adaptado de TAM et al., 2007) 


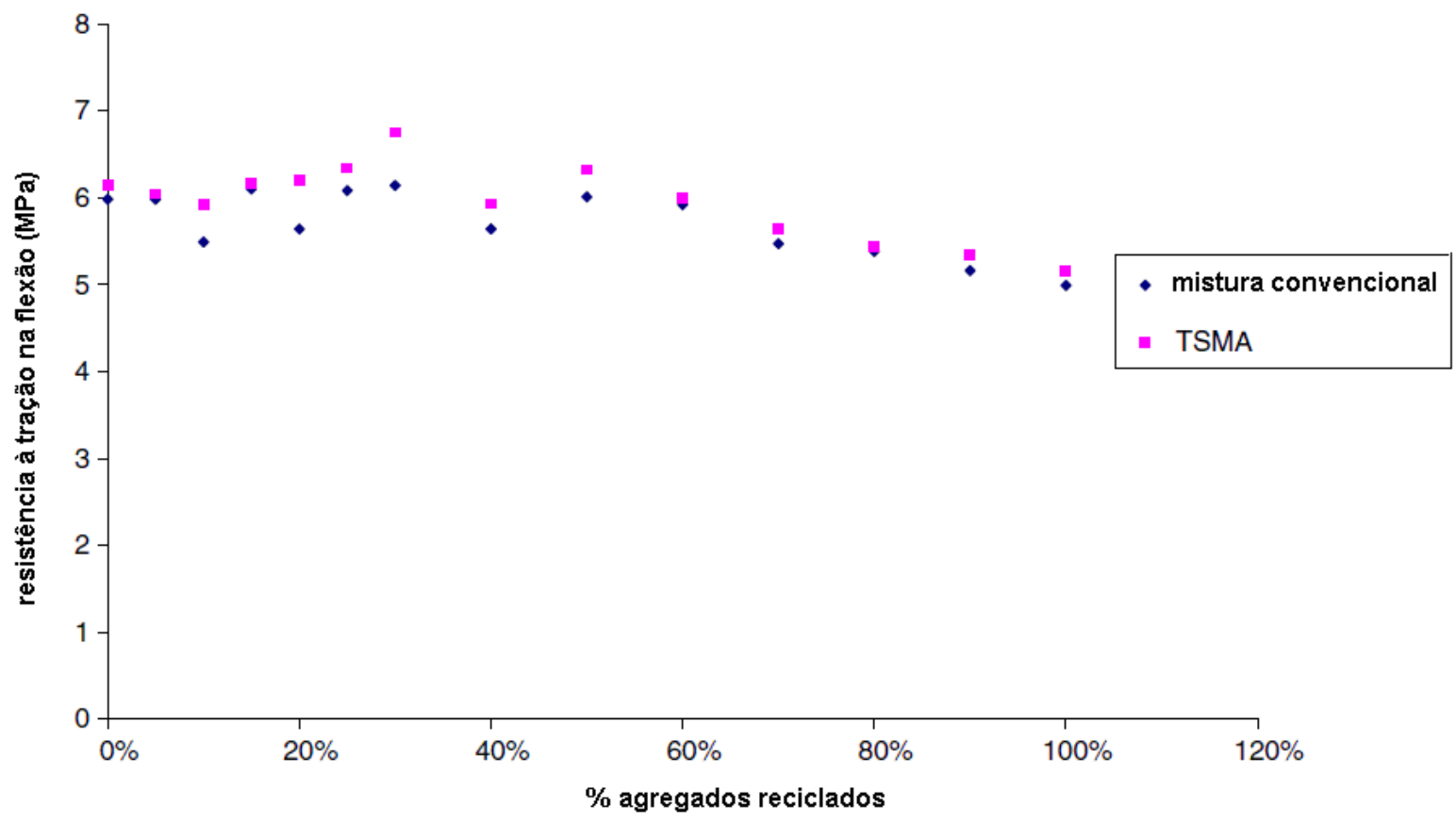

Figura 1.44 - Resistência à tração na flexão aos 28 dias para diferentes teores de substituição dos agregados utilizando o método tradicional de mistura e o método TSMA

(adaptado de TAM et al., 2007)

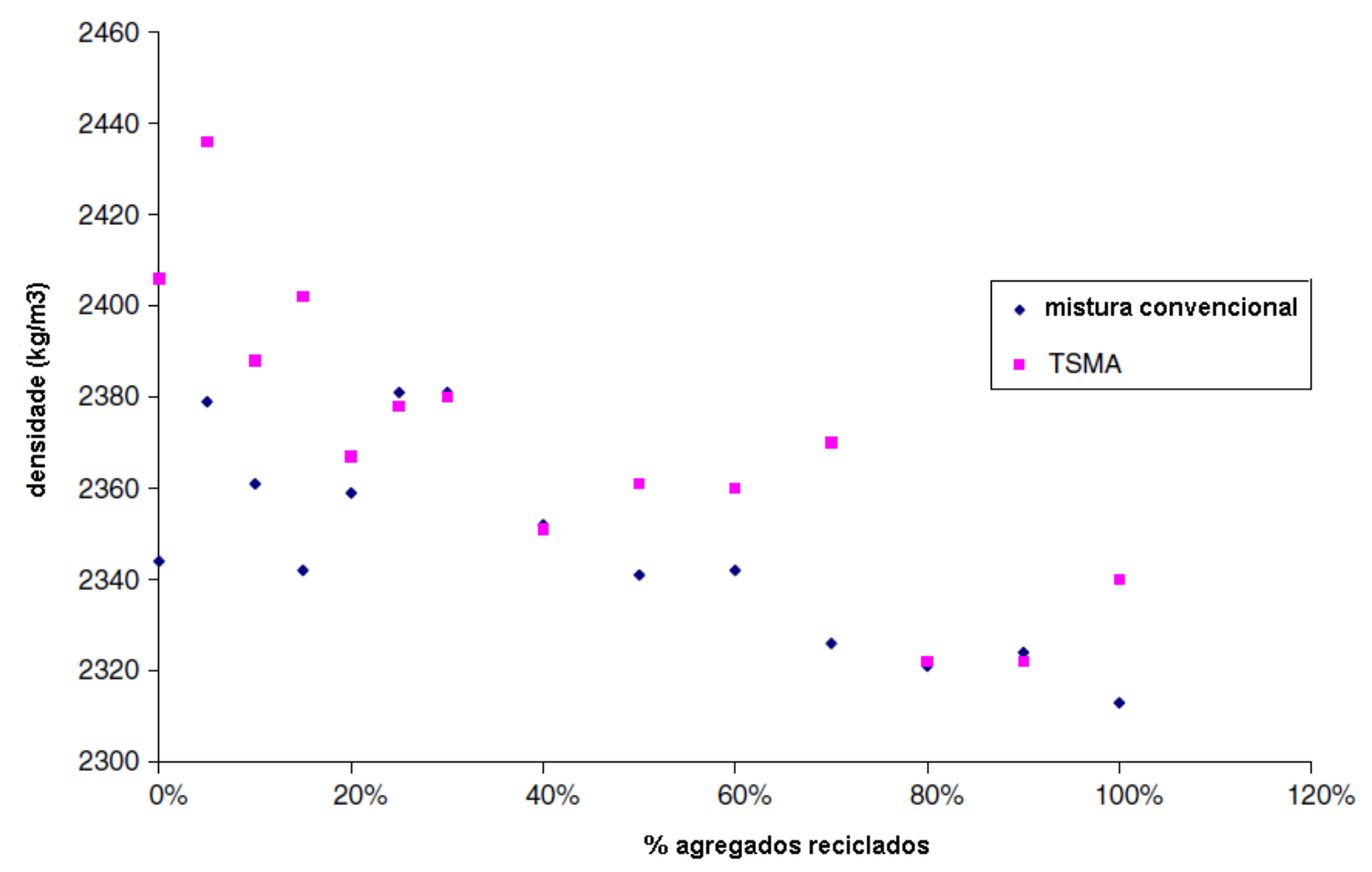

Figura 1.45 - Massa específica aos 28 dias para diferentes teores de substituição dos agregados utilizando o método tradicional de mistura e o método TSMA

(adaptado de TAM et al., 2007)

As Figuras 1.46 e 1.47 ilustram a diferença observada na zona de transição interfacial (ZTI) no concreto misturado pelo processo de duas etapas e pelo 
processo tradicional. Neste último a ZTI é mais pobre, apresentando o concreto menor resistência mecânica.
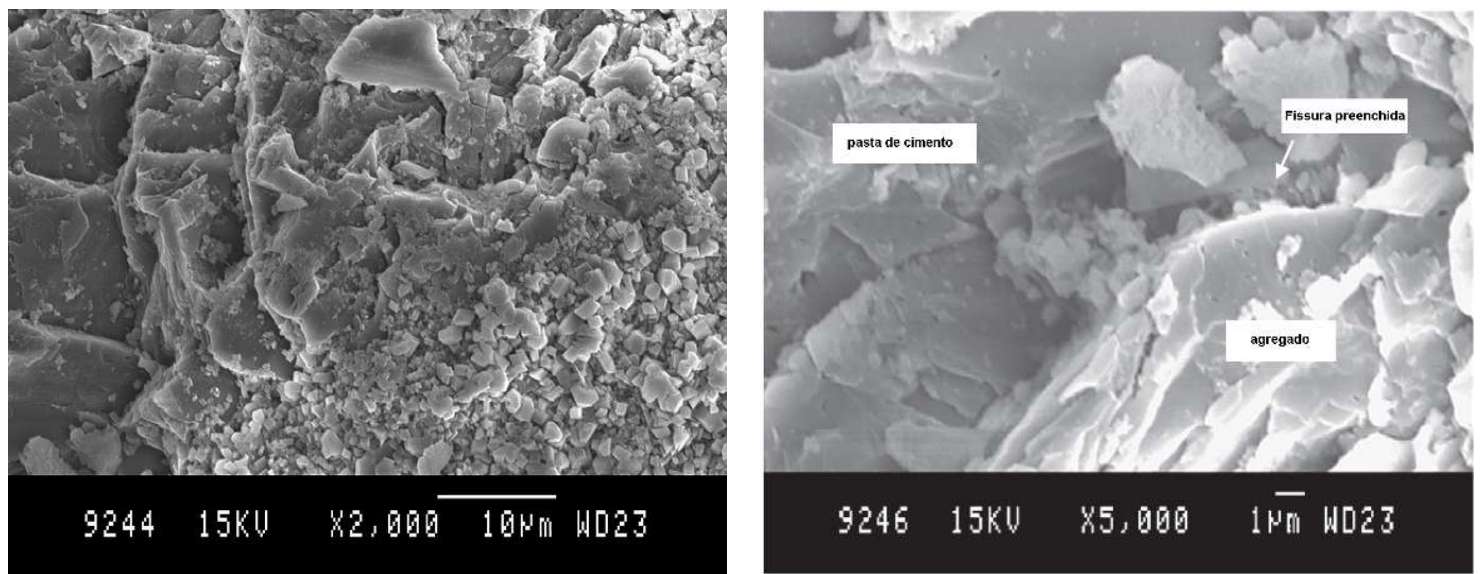

Figura 1.46 - Zona interfacial no concreto misturado em duas etapas (TAM et al., 2007)
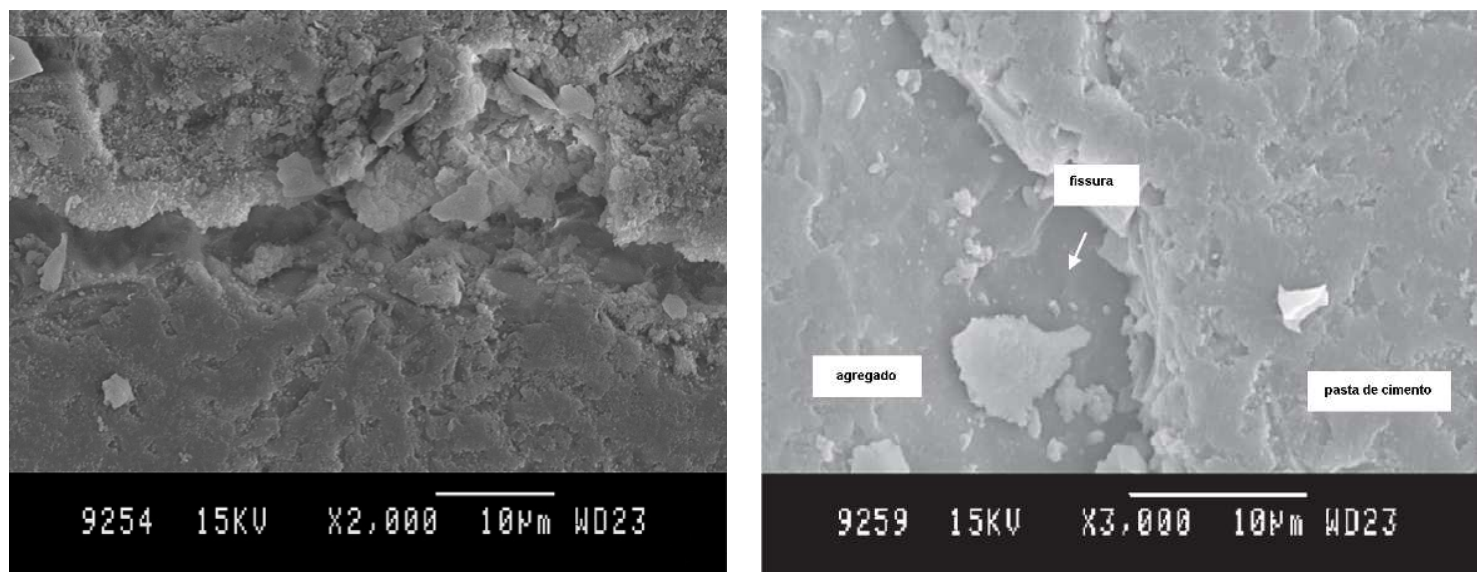

Figura 1.47 - Zona interfacial no concreto misturado pelo método tradicional (TAM et al., 2007)

Os mesmos autores propuseram modificações a esse método de mistura em duas etapas, criando os métodos TSMA $_{S}$ (Two-Stage Mixing Approach $_{(\text {silica fume) }}$ ) e TSMA $_{S C}$ (Two-Stage Mixing Approach $($ silica fume and cement)), método de mistura em duas etapas com sílica ativa, e método de mistura em duas etapas com sílica ativa e cimento (TAM et al., 2008). O TSMA ${ }_{S}$ consiste na adição de sílica ativa e na substituição de $2 \%$ do cimento requerido por certas porcentagens de agregado reciclado no processo de pré-mistura. O restante dos agregados naturais, do cimento e da água são adicionados durante a segunda etapa. No TSMA $\mathrm{Sc}$ o cimento é adicionado proporcionalmente à porcentagem de agregados reciclados utilizados com a adição de sílica ativa no processo de pré-mistura. 
Os autores observaram que tanto o $\mathrm{TSMA}_{S}$ como o $\mathrm{TSMA}_{\mathrm{SC}}$ resultam em maiores resistências se comparados ao TSMA, sendo o TDMA $\mathrm{TS}_{\mathrm{C}}$ aquele que proporcionou melhores resultados (TAM et al., 2008). A Figura 1.48 apresenta a estrutura obtida ao se utilizarem o método de mistura convencional, o método TSMA $\mathrm{TS}_{S}$ o TSMA

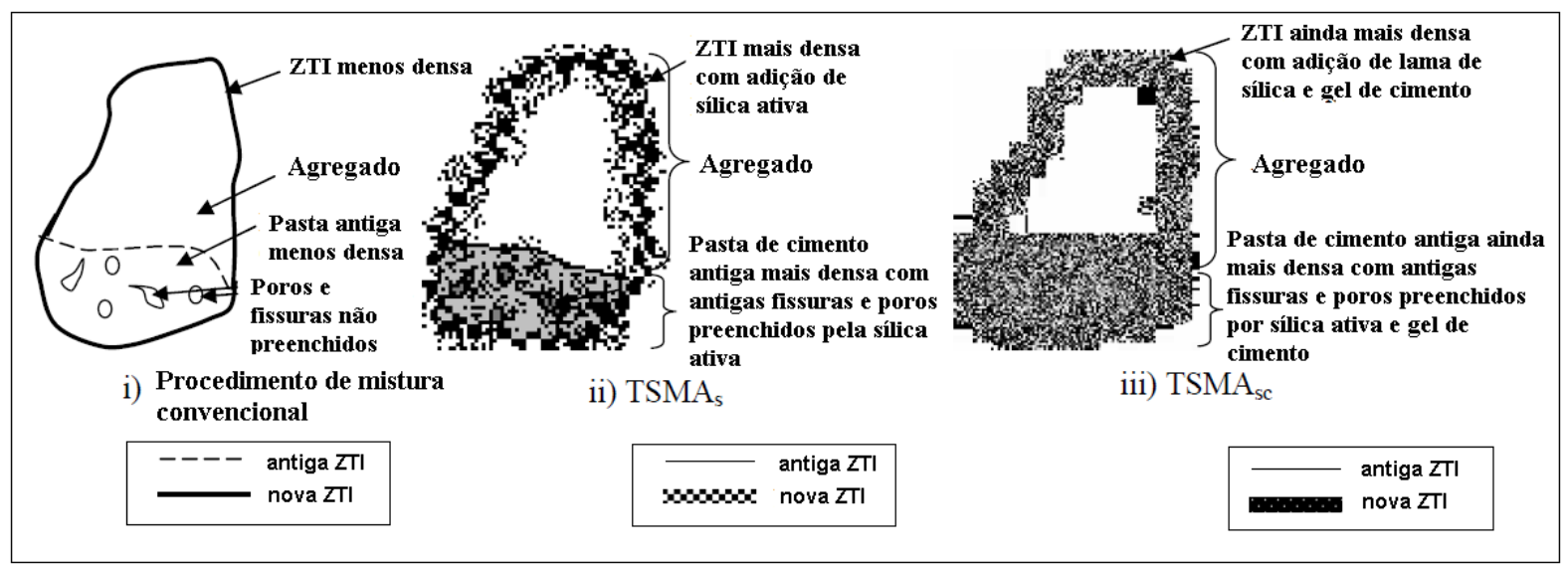

Figura 1.48 - Estrutura após adoção dos métodos de mistura convencional, TSMAS e TSMASC (adaptado de TAM et al., 2008)

Carrijo (2005) utiliza metodologia diferente em seu estudo com agregado proveniente de RCD, adicionando, 10 minutos antes da mistura de todos os componentes do concreto, apenas os agregados e quantidade de água correspondente a 70\% da absorção dos agregados em 24 horas. Esse valor foi adotado considerando que essa é a quantidade de água que os agregados absorvem, aproximadamente, nos primeiros 10 minutos. Entretanto, mesmo com essa medida de compensação da água de absorção, a autora observou que a trabalhabilidade apresentada pelos concretos era bastante variável, fato que atribuiu a outros condicionantes tais como o formato e a textura dos agregados reciclados.

Roesler e Salas (2009), em estudo de reciclagem de pavimento de concreto para o aeroporto de O'Hare, em Chicago, utilizaram o método proposto por Tam. Porém, antes da mistura do concreto, adicionaram uma etapa de pré-molhagem dos agregados reciclados a fim de diminuir a quantidade de água de mistura devido à alta absorção de água por estes apresentadas. Para tanto, os agregados foram submersos em água ou molhados de forma que aproximadamente $80 \%$ da água de absorção estivessem presentes nos agregados na hora da mistura. Os autores estimam que a água previamente absorvida pelos agregados possa posteriormente 
ajudar na cura interna do concreto, provendo uma fonte de água para reagir com o cimento.

Hansen (1992) comenta que o uso de agregados previamente mergulhados na água é sugerido em algumas ocasiões a fim de manter a uniformidade da qualidade do concreto durante a produção, mas que os resultados do uso de agregados saturados no desempenho do concreto em relação ao gelo/degelo não são claros.

Diversos autores afirmam que a melhor forma de se utilizar os agregados reciclados na mistura do concreto é na forma saturada, a fim de reduzir a perda de trabalhabilidade a um valor conhecido observado no concreto feito com agregados naturais (NEALEN e SCHENK, 1998; BUTTLER e MACHADO JR., 2005).

Nealen e Schenk (1998), por exemplo, obtiveram com o uso de agregados reciclados de $\mathrm{RCD}$ em estado saturado, valores de resistência à compressão maiores que aqueles observados em concretos de controle. As curvas de perda de trabalhabilidade obtidas pelos autores são apresentadas nas Figuras 1.49 e 1.50. Os autores explicam que quando o agregado reciclado é utilizado em estado saturado a perda de trabalhabilidade é maior se comparado ao uso de agregados naturais, fato explicado pela superfície mais rugosa dos primeiros e porque o agregado reciclado tende a ser quebrado durante a mistura.

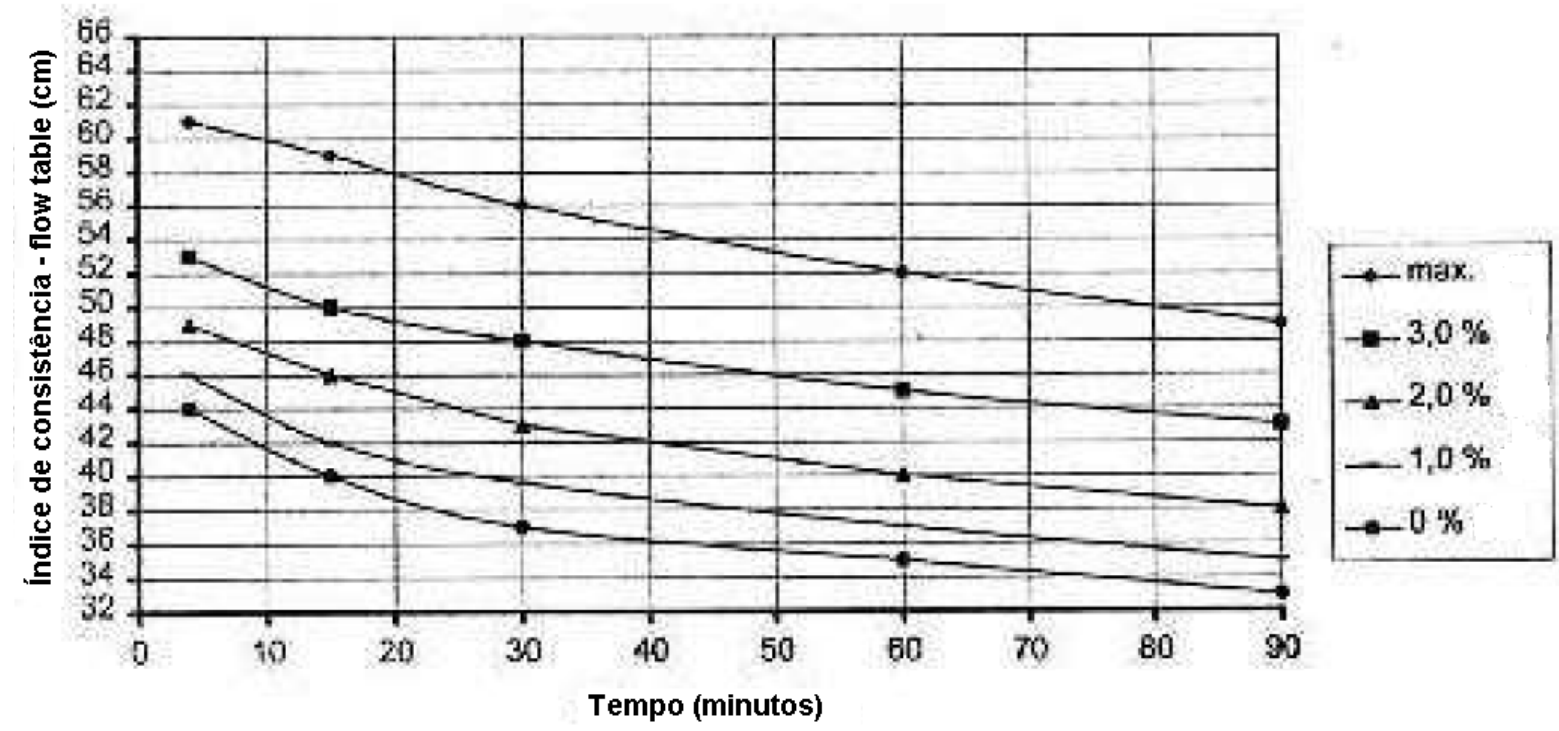

Figura 1.49 - Relação entre o índice de consistência, umidade inicial presente nos agregados e tempo (adaptado de NEALEN e SCHENK, 1998) 


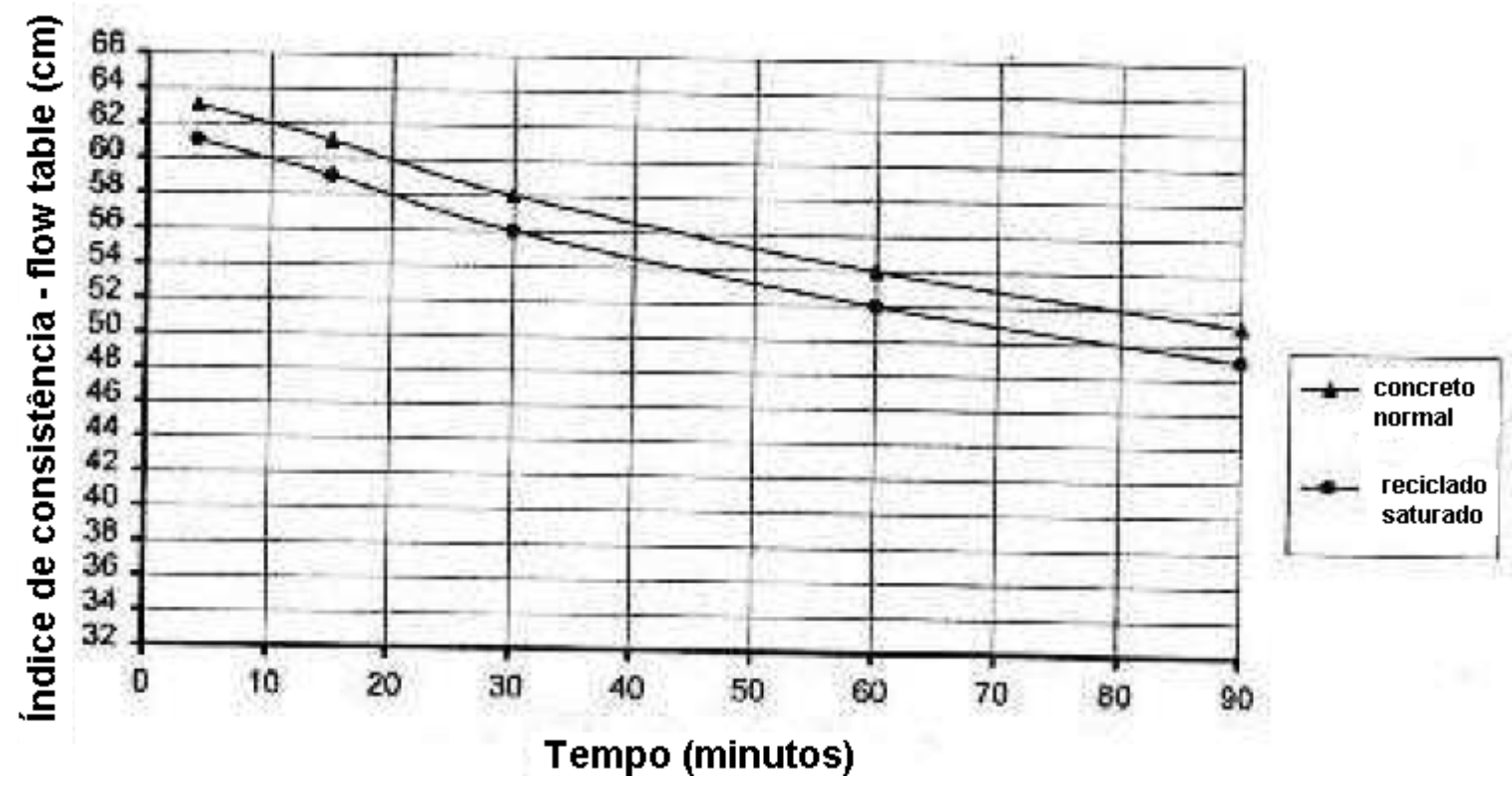

Figura 1.50 - Desenvolvimento de rigidez no concreto com agregados naturais e no concreto com agregados reciclados saturados (adaptado de NEALEN e SCHENK, 1998)

Etxeberria et al. (2007) utilizaram o seguinte método de mistura: primeiro são misturados o cimento e a água por 1 minuto, depois são adicionados os agregados miúdos seguidos dos graúdos e tudo é misturado por 1 minuto, e finalmente é adicionado o aditivo e a mistura segue por mais 1 minuto. Em seu método, os autores afirmam que o agregado reciclado deve ser molhado antes de ser utilizado na mistura, pois, caso contrário, absorveriam muita água proveniente da pasta ocasionando a perda de trabalhabilidade. Eles recomendam que seja adotado um nível de umidade de $80 \%$ do total da absorção. Não deve ser utilizado o estado saturado, pois isso enfraqueceria a zona de transição entre os agregados e a nova pasta de cimento.

De Vries (1996), entretanto, atenta para o risco de supersaturação local ao se molhar previamente os agregados reciclados, podendo causar dificuldades na obtenção de uma mistura homogênea.

Poon et al. (2004a) mostraram que o uso de agregados graúdos reciclados em condição seca ao ar resulta em melhores resultados de resistência à compressão se comparado ao uso destes agregados no estado seco à estufa ou no estado de superfície seca saturado. As maiores perdas de resistência, segundo o estudo, ocorrem quando o agregado é utilizado no estado de superfície seca saturado. Isso 
ocorre, provavelmente, devido à exsudação da água em excesso do interior dos poros dos agregados. (Deve-se ressaltar aqui que nesse estudo a quantidade de água e agregados usados na mistura foi ajustada de acordo com a condição de umidade dos agregados. Quando foram utilizados agregados secos ao ar ou secos em estufa, foi colocada uma quantidade adicional de água na mistura correspondente à necessária para saturar os agregados).

Lima et al. (2007) sugerem o uso dos agregados graúdos sem a molhagem prévia e que se faça uma compensação parcial da absorção de água do agregado miúdo reciclado, considerando-se que a mistura absorverá não somente água mas também partículas de cimento que irão colmatar a superfície dos grãos e reduzir o gradiente de absorção de água. Essa compensação pode ser, como utilizada em seu estudo, de $40 \%$ da absorção total em 24 horas (valor da absorção encontrada nos primeiros 10 minutos para os agregados estudados).

Cervantes et al. (2007), sugerem o uso de agregados reciclados mergulhados em água 1 dia antes de sua utilização e que se considere o excesso de água, acima da necessária para a condição saturada com superfície seca, que seria tipicamente de 1 a $2 \%$, a fim de descontá-la na hora da mistura.

Já Zaharieva et al. (2003) sugerem o uso de agregados graúdos pré molhados com quantidade de água calculada como sendo a diferença entre a água requerida para total saturação dos agregados e a água que é realmente absorvida pelos agregados na hora da mistura.

Silva et al. (2001) adotam, no caso de uso de agregados miúdos reciclados provenientes de RCD, a pré-molhagem para deixá-los com umidade em torno de $8 \%$.

As recomendações encontradas na literatura, quanto à molhagem ou não de agregados reciclados antes da mistura, são controversas. Diversos autores sugerem que se faça a molhagem (ACPA, 2009; ROESLER e SALAS, 2009), enquanto outros afirmam veemente que esta não deve ser feita, sendo recomendado somente aumentar a quantidade de água na mistura (POON et al., 2004a; Tam et al., 2007). 
A ACPA (2009) sugere que em obra seja instalado um sistema de borrifamento nas pilhas de agregado reciclado, a fim de se manter a umidade uniforme durante a produção de concreto.

\subsection{DESEMPENHO DE PAVIMENTOS DE CONCRETO CONTENDO AGREGADOS RECICLADOS}

As características físicas e mecânicas do concreto contendo agregados reciclados, como relatado anteriormente, não são as mesmas do concreto convencional. Além de outras diferenças, a argamassa aderida afeta o coeficiente de expansão térmica e de contração, a retração e a textura do novo concreto (CUTTELL et al., 1997). Tudo isso deve ser levado em conta ao se projetar um pavimento.

Maiores coeficientes de expansão e retração devem ser considerados ao se escolher as dimensões das placas, que devem ser menores, e o material das juntas. Além disso, mudanças na resistência mecânica e no módulo de elasticidade induzem a mudanças na espessura das camadas do pavimento. $E$ deve-se considerar, ainda, uma menor capacidade de transferência de carga por intertravamento de agregados, já que o índice de abrasão é consideravelmente mais elevado no caso de agregados reciclados. A Tabela 1.6 apresenta as modificações mais frequentes em projetos com emprego de agregados reciclados. 
Tabela 1.6 - Recomendações para projetos de pavimentos de concreto contendo agregados reciclados (adaptado de ACPA, 2009)

\begin{tabular}{|c|c|}
\hline Elemento & Recomendação de projeto \\
\hline \multirow[b]{2}{*}{ Tipo de pavimento } & $\begin{array}{l}\text { Em pavimentos de concreto simples (JPCP) utilizar comprimento de placa de } \\
4,6 \mathrm{~m} \text { ou menos a fim de minimizar o potencial de fissuras no meio de placas. }\end{array}$ \\
\hline & $\begin{array}{l}\text { Deve ser considerada a solução armada e continuamente armada (JRCP e } \\
\text { CRCP) no caso de o intertravamento de agregados ser reforçado por } \\
\text { agregados de maiores tamanhos e/ou uma mistura de agregados virgens e } \\
\text { reciclados. }\end{array}$ \\
\hline Espessura de placa & $\begin{array}{l}\text { Semelhantes ou um pouco mais espessas dependendo do projeto e da } \\
\text { resistência oferecida pelo concreto. }\end{array}$ \\
\hline $\begin{array}{l}\text { Distância entre } \\
\text { juntas }\end{array}$ & $\begin{array}{l}\text { A largura das placas deve ser escolhida a fim de se minimizar a incidência de } \\
\text { fissuras no meio de placa (no pavimento de concreto simples - JPCP) ou } \\
\text { manter a abertura das fissuras em um valor mínimo (no pavimento de } \\
\text { concreto armado - JRCP). }\end{array}$ \\
\hline $\begin{array}{l}\text { Transferência de } \\
\text { carga }\end{array}$ & $\begin{array}{l}\text { O critério para o uso de barras de transferência deve ser o mesmo que o } \\
\text { utilizado no caso de concreto convencional. }\end{array}$ \\
\hline Selante de juntas & $\begin{array}{l}\text { As dimensões devem considerar tanto o material do selante como os } \\
\text { movimentos esperados causados pelos efeitos de temperatura e retração, } \\
\text { que são maiores no caso do uso de agregados reciclados. }\end{array}$ \\
\hline Tipo de sub-base & $\begin{array}{l}\text { O material da sub-base deve ser escolhido levando em consideração os } \\
\text { requisitos estruturais, assim como no caso do concreto convencional. Para } \\
\text { pavimentos de concreto contendo agregados reciclados de placas } \\
\text { previamente apresentando trincas devido ao gelo/degelo e reação álcali- } \\
\text { sílica, deve ser considerado o uso de sub-base drenante. }\end{array}$ \\
\hline Reforço & $\begin{array}{l}\text { Maiores quantidades de barras longitudinais de ligação podem ser } \\
\text { necessárias em pavimentos de concreto simples e continuamente armados } \\
\text { (JRCP e CRCP) a fim de controlar as fissuras para que o intertravamento } \\
\text { entre agregados seja mantido. }\end{array}$ \\
\hline $\begin{array}{l}\text { Tipo de } \\
\text { acostamento }\end{array}$ & os utilizados em pavimentos de concreto convencionais. \\
\hline
\end{tabular}

Krenn e Stinglhammer (1994) apresentaram um dos primeiros resultados de execução de pavimentos de concreto reciclados com emprego de agregados provenientes de britagem de antigos pavimentos de concreto (com mais de 30 anos) necessitando de reconstrução. Em 1989-1990 cerca de 50\% do pavimento de concreto da rodovia A1 ligando Viena a Salzburg foi reconstruído empregando-se os agregados com dimensões de 4 a $32 \mathrm{~mm}$ provenientes das placas britadas e mais parcela de areia natural de 0 a $4 \mathrm{~mm}$. A mistura idealizada e estudada em laboratório e em campo poderia eventualmente até conter material britado de concreto asfáltico (CA) existente sobre o pavimento de concreto em determinadas proporções; suas proporções finais foram: $350 \mathrm{~kg} / \mathrm{m}^{3}$ de cimento Portland comum, $700 \mathrm{~kg} / \mathrm{m}^{3}$ de areia virgem $0 / 4,1.150 \mathrm{~kg} / \mathrm{m}^{3}$ de concreto britado e classificado $4 / 32$, relação a/c de 0,41 e uso de incorporador de $\operatorname{ar}\left(0,245 \mathrm{~kg} / \mathrm{m}^{3}\right)$. Os resultados obtidos foram, inclusive, superiores que para um concreto de controle com pedregulho 
quartzoso, conforme indicados nas Figuras 1.51 e 1.52. Observa-se que a perda de resistência do material, relativamente a um concreto virgem, está bastante associada ao aumento da presença de reciclados de mistura asfáltica na mistura reciclada. Isto porque o filme asfáltico envolvendo os agregados prejudica o estabelecimento de ligações entre a nova pasta de cimento e tais agregados durante a hidratação dos compostos do ligante hidráulico, o que ocasiona a perda de resistência da mistura, que, contudo não é expressiva mesmo para $33 \%$ de reciclados de misturas asfálticas presentes, como se extrai dos resultados.

O trabalho de Krenn e Stinglhammer (1994) afirma que, além do possível ganho de resistência dos materiais, com auxílio da introdução de areia virgem, houve um benefício ambiental de economia de cerca de 205.000 toneladas de pedregulho virgem e também ao se evitar qualquer ocorrência de bota-fora na obra. Além disso, foram evitados 30.000 carregamentos de longa distância de caminhões pelo fato da reciclagem ocorrer no canteiro de obras. Em termos de custos a obra se beneficiou de uma economia de $10 \%$ comparada ao uso de concreto virgem, sem levar em conta as economias indiretas relacionadas aos aspectos ambientais.

Concreto Reciclado na Rodovia A1 - Áustria

Resistência à compressão simples

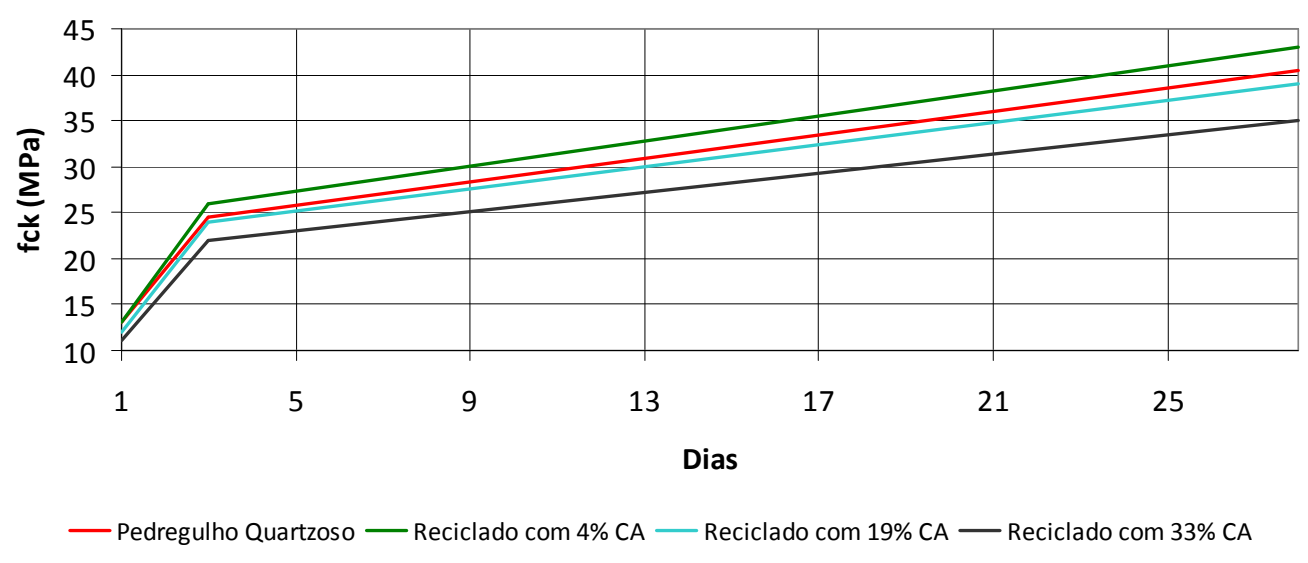

Figura 1.51 - Resistência à compressão do concreto reciclado na Rodovia A1 - Áustria (adaptado de KRENN e STINGLHAMMER, 1994) 
Concreto Reciclado na Rodovia A1 - Áustria Resistência à tração na flexão

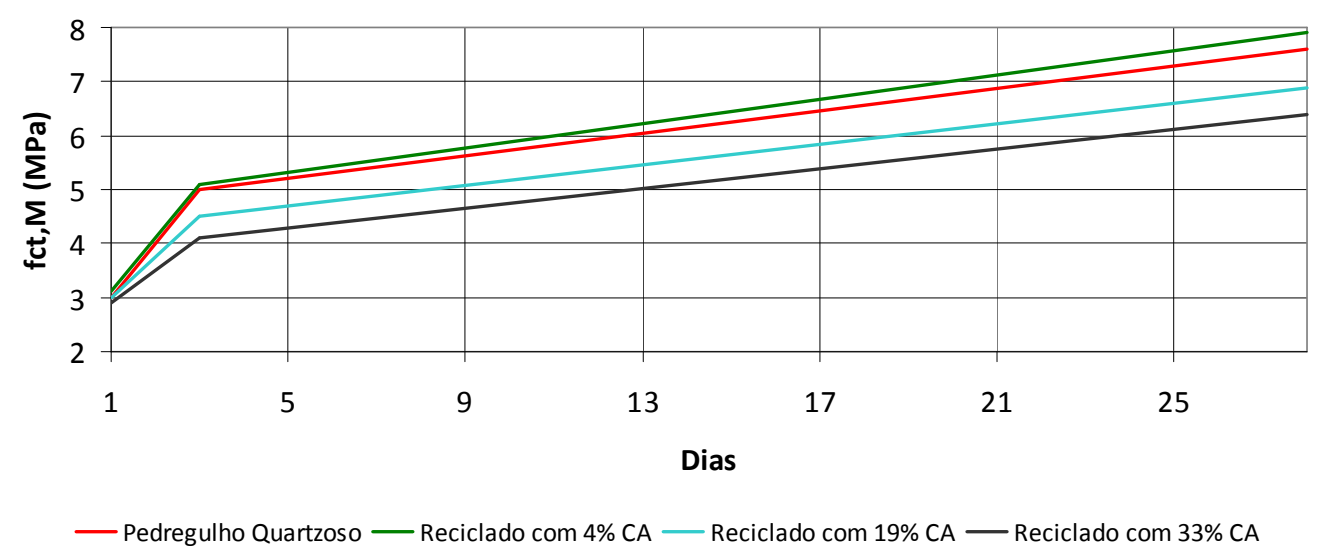

Figura 1.52 - Resistência à tração na flexão do concreto reciclado na Rodovia A1 - Áustria (adaptado de KRENN e STINGLHAMMER, 1994)

Alguns projetos recentes de pavimentos de concreto construídos com agregados reciclados provenientes da própria rodovia e que apresentaram bom desempenho são relatados por Cuttell et al. (1997). Seu trabalho de pesquisa foi consequência da análise de pavimentos de concreto em nove rodovias, compreendendo 16 seções de testes.

As investigações em campo envolveram a avaliação de pavimentos de concreto reciclados empregados em cinco estados dos EUA, cujas atividades envolveram uma série de técnicas de avaliação incluindo inventário das condições dos pavimentos, testes de carga para avaliações de deflexões reversíveis com o falling weight deflectometer (FWD), extração de amostras em pista e estimativa do valor de serventia atual (VSA). Os estudos permitiram delinear as seguintes observações e conclusões:

i. Concretos reciclados que apresentavam menor quantidade de argamassa, ou seja, durante o processo de reciclagem (britagem e classificação) houve efetiva exclusão de argamassa dos agregados originais, apresentaram melhor desempenho em novos pavimentos.

ii. Os efeitos de variações no módulo de finura em diferentes concretos não foram percebidos, embora existisse uma expectativa de interferência na 
resistência para adições de até $25 \%$ de agregados miúdos reciclados em substituição aos naturais, tendo em vista estudos anteriormente realizados por Yrjanson (1989).

iii. A massa específica aparente dos grãos dos concretos reciclados encontrouse de 0,2 a 0,3 t/m $\mathrm{m}^{3}$ abaixo da massa específica aparente dos grãos empregados em seções de controle, com pavimentos de concreto contendo agregados virgens, o que foi atribuído à presença da antiga argamassa menos densa.

iv. Os dados de controle tecnológico das obras revelaram clara queda na trabalhabilidade das misturas recicladas, o que foi atribuído a fatores como a angularidade dos grãos reciclados, sua superfície rugosa e porosa. As formas naturais que têm sido sugeridas para inverter essa tendência são medidas de limitação na porcentagem de agregados miúdos reciclados (não superior a $25 \%$ ), uso de plastificantes e incorporação de cinzas volantes nas misturas.

v. Nos casos de seções de pavimentos que respeitaram as limitações quanto a agregados miúdos de origem reciclada, a resistência à compressão das amostras extraídas de campo aumentou em relação aos concretos convencionais extraídos de seções de controle. ${ }^{6}$

vi. Os valores de módulo de elasticidade dinâmico dos concretos com agregados reciclados de concretos diminuíram, o que é atribuído à maior porosidade presente nos concretos reciclados. Esta tendência de queda também foi observada por meio de retroanálise de bacias de deflexões medidas em campo com FWD. Ricci e Balbo (2008) apresentam resultados bastante semelhantes para concretos compactados com rolo empregando em suas dosagens de 50 a 100\% de agregados graúdos reciclados e 50\% de agregados miúdos reciclados. Concretos com 100\% de agregados graúdos

\footnotetext{
${ }^{6} \mathrm{O}$ artigo consultado não descreve como foi feita a mistura dos concretos, mas indica que houve uma redução na trabalhabilidade dos concretos contendo agregados reciclados. É possível que não tenha sido feita a compensação de água a fim de manter a relação a/c efetiva no concreto reciclado a mesma do concreto convencional.
} 
reciclados de um antigo pavimento de concreto tiveram seus módulos de elasticidade reduzidos em $50 \%$ em relação a um concreto de controle na pesquisa.

vii. Os valores de coeficiente de expansão térmica dos concretos reciclados apresentaram-se em geral maiores do que aqueles de concretos convencionais de controle empregados, o que significa menores restrições do material à sua expansão volumétrica devido às flutuações de temperatura.

Como principais conclusões do estudo os autores indicam que os concretos reciclados apresentaram desempenho semelhante aos concretos com agregados virgens na medida em que o processo de reciclagem era eficiente para remover ao máximo a argamassa que envolvia os agregados originais. Como melhores recomendações aqueles pesquisadores enfatizaram que o concreto reciclado deveria ser considerado um material que requer maior investigação no momento de sua aplicação em comparação aos agregados novos. Tendo em vista que o concreto reciclado pode apresentar elevada retração de secagem e valores maiores de coeficiente de expansão térmica, é natural a exigência de se repensar o afastamento das juntas serradas durante a construção de pavimentos com este tipo de material; quando fresco, juntas menos espaçadas permitem melhor controle de fissuras de retração; quando endurecidos, o elevado valor de coeficiente de expansão térmica exige menor afastamento entre juntas para se evitar a compressão de faces de placas, o que geraria futuros problemas de quebras em juntas.

Tompkins et al. (2008) afirmam que os pavimentos reconstruídos por processo de reciclagem do concreto entre 1993 e 1994 apresentaram desempenho muito bom (Figuras 1.53 e 1.54, fotos de março de 2008) após inspeção visual da rodovia, tendo-se em conta também que o volume diário médio no local é de 56.000 veículos, sendo $12 \%$ caminhões $(6.720$ caminhões por dia, metade do volume ocorrente na Avenida dos Bandeirantes, na capital paulista); ainda deve ser levado em conta que durante seis meses por ano há neve na superfície desses pavimentos o que exigiu uso contínuo, nesses períodos, de sais de descongelamento, nos últimos 14 anos. Além disso, a superfície desses pavimentos fica sujeita a pneus 
envoltos por correntes durante os períodos de neve, o que naturalmente causa desgaste por abrasão.

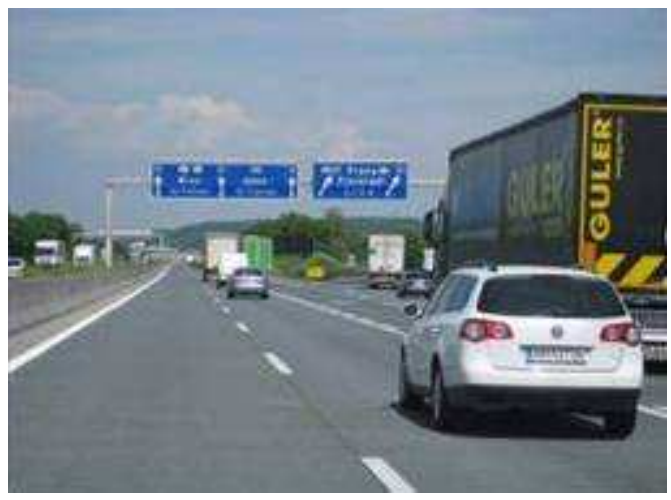

Figura 1.53 - Pavimento de concreto reciclado na rodovia Viena-Salzburg após 14 anos de sua construção (março de 2008)

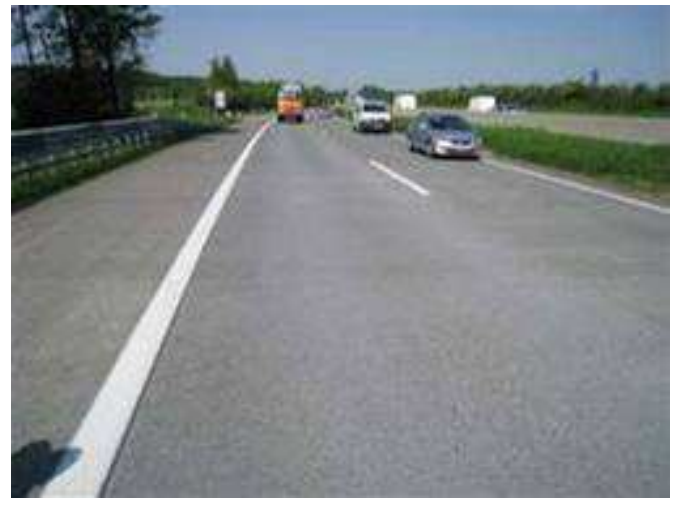

Figura 1.54 - Pavimento de concreto reciclado na rodovia Viena-Salzburg após 14 anos de sua construção (março de 2008)

Nota-se que há uma correlação entre a principal conclusão de Cuttell et al. (1997) em experimentos nos Estados Unidos com a exigência austríaca de se remover a parte fina resultante de britagem do antigo pavimento de concreto, qual seja, de granulometria $0 / 4 \mathrm{~mm}$, pois em ambos os casos se está referindo à grandes quantidades de argamassa presente no antigo concreto. Os concretos reciclados no caso austríaco foram empregados como camada de $22 \mathrm{~cm}$ sob camada de concreto novo com agregados expostos com espessura de $4 \mathrm{~cm}$. $O$ conceito de camada superior de concreto com agregados virgens de alta qualidade se insere, conjuntamente com a reciclagem do pavimento de concreto anterior que é a camada inferior da nova placa de concreto, na questão da economia de materiais, pois, se por um lado nesses países mais desenvolvidos tecnologicamente e socialmente já ocorre há décadas exigências relacionadas à segurança do rolamento dos veículos, uma camada esbelta de concreto novo auxilia na redução de custos, atendendo ao requisito de desempenho chamado por aderência pneu-pavimento (HAIDER e VON FAHRBAHNOBERFLÄCHEN, 2007; FLEISCHER, 2003).

Sturtevant et al. (2008) apresentam uma avaliação posterior ao estudo de Cuttell et al. (1997) mencionado, focando no desempenho observado, passada mais de uma década de operação desses pavimentos. Foi verificado, por meio de avaliações de patologias e de padrões de conforto (Tabela 1.7), bem como por meio de avaliações estruturais, que os pavimentos de concreto reciclados apresentaram desempenho 
semelhante àqueles de seções de teste de controle executadas com agregados virgens. Os autores atribuem o sucesso ao emprego de agregados cujo processo de reciclagem eliminou grande parte da argamassa antiga da superfície desses agregados, embora reconheçam que, sob outro ponto de vista, a reciclagem não se dá a $100 \%$ procedendo dessa maneira.

O aproveitamento dos agregados dos concretos antigos com limitação de britagem com diâmetro máximo de $25 \mathrm{~mm}$ resultou em aproveitamento de 55 a $65 \%$ do concreto existente, enquanto que, quanto se tolera até $38 \mathrm{~mm}$, o reaproveitamento atinge $80 \%$. O contraponto feito é que a não eliminação da argamassa antiga em grande quantidade poderá resultar em problemas de trabalhabilidade, durabilidade e resistência do concreto. O único projeto que não havia levado a efeito a eliminação da argamassa antiga é aquele descrito por Minnesota 4-1 na Tabela 1.7, que desde o princípio, apresentou problemas de fissuração importantes, resultando em perda de serventia de 4 para 3 no tempo de serviço avaliado, ou seja, o pior desempenho dentre os demais. A Tabela 1.8 apresenta um resumo do desempenho das seções estudadas em 2006.

Tabela 1.7 - Resultados de desempenho de pavimentos de concreto reciclados nos EUA após mais de uma década de serviço (adaptado de Sturtevant et al., 2008).

\begin{tabular}{lllllccccc}
\hline $\begin{array}{l}\text { Projeto } \\
\text { (identificação) }\end{array}$ & $\begin{array}{l}\text { Tipo de } \\
\text { concreto }\end{array}$ & $\begin{array}{l}\text { Escalonamento } \\
\text { de juntas } \\
\text { (mm) }\end{array}$ & $\begin{array}{l}\text { Fissuras } \\
\text { transversais } \\
\text { (\% de placas) }\end{array}$ & $\begin{array}{l}\text { Esborcinamentos } \\
\text { em juntas } \\
\text { transversais } \\
\text { (\% de juntas) }\end{array}$ & $\begin{array}{l}\text { Valor de } \\
\text { serventia } \\
\text { atual (VSA) }\end{array}$ \\
ANO DE LEVANTAMENTO & $\mathbf{1 9 9 4}$ & $\mathbf{2 0 0 6}$ & $\mathbf{1 9 9 4}$ & $\mathbf{2 0 0 6}$ & $\mathbf{1 9 9 4}$ & $\mathbf{2 0 0 6}$ & $\mathbf{1 9 9 4}$ & $\mathbf{2 0 0 6}$ \\
Connecticut-1 & reciclado & 0.3 & 1.0 & 66 & 68 & 27 & 92 & 3.4 & 3.7 \\
Connecticut -2 & convencional & 0.3 & 1.1 & 93 & 93 & 33 & 66 & 3.5 & 3.2 \\
Kansas-1 & reciclado & 2.3 & $\mathrm{n} / \mathrm{a}$ & 0 & $\mathrm{n} / \mathrm{a}$ & 0 & $\mathrm{n} / \mathrm{a}$ & 3.8 & $\mathrm{n} / \mathrm{a}$ \\
Kansas -2 & convencional & 3.3 & $\mathrm{n} / \mathrm{a}$ & 0 & $\mathrm{n} / \mathrm{a}$ & 0 & $\mathrm{n} / \mathrm{a}$ & 3.8 & $\mathrm{n} / \mathrm{a}$ \\
Minnesota1 & reciclado & 0.5 & 0.9 & 1 & 31 & 3 & 76 & 3.9 & 3.7 \\
Minnesota 1-2 & reciclado & 0.5 & 1.3 & 0 & 0 & 0 & 54 & 4.0 & 4.0 \\
Minnesota 2-1 & reciclado & 0.8 & 0.6 & 84 & 90 & 61 & 46 & 4.1 & 4.0 \\
Minnesota 2-1 & reciclado & $\mathrm{n} / \mathrm{a}$ & 0.5 & 82 & 92 & 42 & 66 & 4.3 & 3.8 \\
Minnesota 3 & reciclado & 6.1 & 0.3 & 2 & 12 & 3 & 89 & 3.0 & 4.3 \\
Minnesota 4-1 & reciclado & 1.0 & 0.9 & 88 & 92 & 80 & 81 & 4.0 & 3.0 \\
Minnesota 5-2 & convencional & 0.8 & 0.9 & 22 & 24 & 0 & 100 & 4.2 & 3.8 \\
Wisconsin 1 & reciclado & 2.8 & $\mathrm{n} / \mathrm{a}$ & 8 & $\mathrm{n} / \mathrm{a}$ & 0 & $\mathrm{n} / \mathrm{a}$ & 4.1 & 2.8 \\
Wisconsin 2 & reciclado & 0.5 & 0.5 & 2 & 3 & 0 & 91 & 3.8 & 3.7 \\
Wisconsin 3 & reciclado & $\mathrm{n} / \mathrm{a}$ & $\mathrm{n} / \mathrm{a}$ & $\mathrm{n} / \mathrm{a}$ & $\mathrm{n} / \mathrm{a}$ & 134 & $\mathrm{n} / \mathrm{a}$ & 3.9 & $\mathrm{n} / \mathrm{a}$ \\
Wisconsin 4 & reciclado & $\mathrm{n} / \mathrm{a}$ & $\mathrm{n} / \mathrm{a}$ & $\mathrm{n} / \mathrm{a}$ & $\mathrm{n} / \mathrm{a}$ & 30 & $\mathrm{n} / \mathrm{a}$ & 4.0 & $\mathrm{n} / \mathrm{a}$ \\
Wyoming 5-1 & reciclado & 2.0 & 0.7 & 0 & 0 & 0 & 47 & 3.6 & 4.5 \\
Wyoming 5-2 & convencional & 2.0 & 0.6 & 0 & 0 & 0 & 77 & 3.6 & 4.2 \\
\hline
\end{tabular}


Tabela 1.8 - Dados médios de comparação entre seções de controle e recicladas em 2006 (adaptado de STURTEVANT, 2007)

\begin{tabular}{|c|c|c|c|c|}
\hline Ensaio & $\begin{array}{l}\text { Média } \\
\text { reciclado }\end{array}$ & $\begin{array}{l}\text { Média } \\
\text { controle }\end{array}$ & $\begin{array}{c}\text { Diferença } \\
\text { (reciclado } x \text { controle) }\end{array}$ & Melhor \\
\hline Diâmetro máx. do agregado & 32 & 32 & $0 \%$ & $=$ \\
\hline $\begin{array}{l}\text { Porcentagem de agregados miúdos } \\
\text { reciclados }\end{array}$ & $12 \%$ & $0 \%$ & $12 \%$ & C \\
\hline $\begin{array}{l}\text { Esborcinamento de juntas } \\
\text { transversais, \% de juntas }\end{array}$ & $80 \%$ & $74 \%$ & $6 \%$ & C \\
\hline $\begin{array}{l}\text { Danos em selante de juntas } \\
\text { transversais, \% de juntas }\end{array}$ & $83 \%$ & $97 \%$ & $-14 \%$ & $\mathrm{R}$ \\
\hline $\begin{array}{l}\text { Danos em selante de juntas } \\
\text { longitudinais, } \mathrm{m} / \mathrm{km}\end{array}$ & 997 (99\%) & $1000(100 \%)$ & $-1 \%$ & $\mathrm{R}$ \\
\hline $\begin{array}{l}\text { Trincas de durabilidade (relacionadas } \\
\text { ao gelo/degelo), \% de placas }\end{array}$ & $13 \%$ & $0 \%$ & $13 \%$ & C \\
\hline Bombeamento de finos, $\%$ de placas & $0 \%$ & $0 \%$ & $0 \%$ & $=$ \\
\hline $\begin{array}{l}\text { Deterioração de placas/remendos, \% } \\
\text { de placas }\end{array}$ & $1 \%$ & $0 \%$ & $1 \%$ & C \\
\hline $\begin{array}{l}\text { Escalonamento médio entre a pista e o } \\
\text { acostamento, } \mathrm{mm}\end{array}$ & 13 & 21 & $-8(-38 \%)$ & $\mathrm{R}$ \\
\hline $\begin{array}{l}\text { Separação média entre a pista e o } \\
\text { acostamento, } \mathrm{mm}\end{array}$ & 6 & 10 & $-4(-40 \%)$ & $\mathrm{R}$ \\
\hline $\begin{array}{l}\text { Escalonamento médio entre placas, } \\
\mathrm{mm}\end{array}$ & 1,2 & 1,0 & $0,2(20 \%)$ & C \\
\hline Distância média entre juntas, mm & 13 & 11 & $2(18 \%)$ & C \\
\hline Trinca longitudinal, $\mathrm{m} / \mathrm{km}$ & $326(33 \%)$ & $2(<1 \%)$ & $324(33 \%)$ & C \\
\hline Trinca transversal, $\%$ de placas & $45 \%$ & $30 \%$ & $15 \%$ & C \\
\hline Trincas transversais deterioradas $/ \mathrm{km}$ & 52 & 7 & 45 & C \\
\hline Trincas transversais totais $/ \mathrm{km}$ & 58 & 17 & 41 & C \\
\hline Valor de serventia atual & 3,7 & 3,8 & $-0,1(-3 \%)$ & C \\
\hline $\mid \mathrm{RI}$ & 1,1 & 1,0 & $0,1(10 \%)$ & C \\
\hline Resistência à tração (MPa) & 3,1 & 3,1 & 0 & $=$ \\
\hline Resistência à compressão (MPa) & 48 & 47,5 & $0,5(1 \%)$ & $\mathrm{R}$ \\
\hline Reação com acetato de uranila & baixa & inexistente & 1 nível & $\mathrm{C}$ \\
\hline $\begin{array}{l}\text { \% de expansão aos } 108 \text { dias - } \\
\text { ASTM1293 modificada }\end{array}$ & $0,2569 \%$ & $0,1670 \%$ & $0,0899(54 \%)$ & C \\
\hline Módulo de Young (GPa) & 28,4 & 34,1 & $-5,7(-17 \%)$ & $\mathrm{C}$ \\
\hline $\begin{array}{l}\text { Razão volumétrica da textura da } \\
\text { superfície }(\text { volumetric surface texture } \\
\left.\text { ratio - VSTR }{ }^{7}\right)\left(\mathrm{cm}^{3} / \mathrm{cm}^{2}\right)\end{array}$ & 0,4131 & 0,7315 & $-44 \%$ & C \\
\hline
\end{tabular}

C - convencional / $\mathrm{R}$ - reciclado

7 O VSTR representa o volume da textura acima e abaixo do nível médio da superfície de determinados segmentos da superfície. É calculado através da expressão:

$$
\operatorname{VSTR}=\frac{\Sigma\left|R_{i} A_{i}\right|+\Sigma\left|S_{j} A_{j}\right|}{\Sigma\left(A_{i}+A_{j}\right)}
$$

Onde $R_{i}$ é a distância dos segmentos localizados acima do nível médio até este; $S_{j}$ é a distância dos segmentos localizados abaixo do nível médio até este; e $A_{i}$ ou $A_{j}$ é a área projetada por cada pequeno segmento na superfície média. 
Os resultados indicam que para a maioria dos fatores estudados a diferença no desempenho dos pavimentos reciclados e de controle é estatisticamente desprezível, com exceção das trincas de durabilidade e das trincas longitudinais. Todas as seções que apresentaram trincas de durabilidade constituem pavimento reciclado, o que indica que devem ser feitos ensaios próprios para detectar a possibilidade desse tipo de defeito em concretos com agregado reciclado. (Vale ressaltar que no caso brasileiro as trincas de durabilidade não são agravantes, pois estão relacionadas a climas muito severos em que ocorre o fenômeno de gelo/degelo.)

Segundo o United States Department of Transportation (2004) os principais problemas que tiveram de ser superados no emprego dos agregados reciclados de pavimentos de concreto em vários estados americanos, com destaque para o Texas, foram: (1) corrigir os problemas de trabalhabilidade relacionados à elevada absorção de água apresentada pelos agregados reciclados; (2) controle do aumento da fluência e da retração dos concretos com estes agregados; (3) perda de resistência imposta por excessiva presença de finos reciclados nas misturas; (4) surgimento de trincas associadas aos cantos de placas e ao clima invernal rigoroso quando o agregado reciclado possui dimensões superiores a $25 \mathrm{~mm}$.

O United States Department of Transportation (2004) ainda recomenda que a utilização de agregados miúdos produzidos na britagem dos concretos seja feita somente em até 30\% como substituição do agregado miúdo natural.

Muitos estudos já confirmaram que o uso de agregados graúdos reciclados no pavimento de concreto resulta em pavimentos duráveis e resistentes, mas o uso dos agregados miúdos reciclados ainda é controverso. Existem diversos casos em que o uso destes prejudicou substancialmente a trabalhabilidade e a resistência apresentada pelo concreto, tornando o seu uso impraticável. Portanto, é largamente recomendado por diversos autores que se limite o teor de substituição de agregados miúdos naturais por reciclados em aproximadamente 25 a 30\% (EICKSCHEN e SIEBEL, 1998; UNITED STATES DEPARTMENT OF TRANSPORTATION, 2004). A explicação para tais efeitos prejudiciais é que os agregados miúdos reciclados são constituídos basicamente de partículas de pasta, apresentando valores de absorção 
muito altos (6\% a 12\%) e acarretando aumentos expressivos na retração e dilatação do concreto. (HENDRICKS, 1994 apud VANCURA et al., 2009). Na Alemanha, os agregados miúdos produzidos na britagem de placas de concreto são normalmente utilizados em camadas de proteção ao congelamento e camadas de sub-base tratadas com cimento (EICKSCHEN e SIEBEL, 1998).

Contudo, se encontra na literatura européia um caso de $100 \%$ de reaproveitamento do agregado do pavimento de concreto demolido e reciclado, com resultados de desempenho amplamente favoráveis, em uma rodovia na Suíça, sendo que aparentemente tal efeito dos agregados miúdos com sua porosidade não teve consequências para o comportamento estrutural do novo pavimento. Atribuí-se a esse sucesso o fato de separar os agregados em 4 frações antes do seu uso, evitando-se assim a segregação dos mesmos, e o fato de assegurar que eles estejam totalmente saturados em água antes da sua utilização (através da molhagem dos mesmos pelo menos 48 horas antes da mistura). Vale ressaltar, que a mistura utilizada no projeto contava com a adição de plastificante, agente incorporador de ar e sílica ativa (WERNER, 1994).

Existem também outros casos favoráveis de reaproveitamento do agregado miúdo reciclado em até 50\% conforme relatam Vancura et al. (2009) e Shayan e Xu (2003), com a adição de sílica ativa, agente incorporador de ar e plastificante.

Steigenberger (2003) oferece alguns detalhes sobre outras rodovias austríacas que tiveram seus pavimentos de concreto reciclados, como no caso da rodovia $A 1$ em trecho próximo a Vorchdorf. O concreto reciclado foi nesse caso empregado como camada inferior das placas com $21 \mathrm{~cm}$ em 1999, sendo a camada superior de concreto novo com agregado exposto de $5 \mathrm{~cm}$ de espessura. A base desse pavimento ainda foi executada com $21 \mathrm{~cm}$ do próprio agregado reciclado de concreto com diâmetro máximo de $32 \mathrm{~mm}$. As juntas serradas foram executadas a cada 5,5 m de distância para a formação das placas. Tais tipos de pavimentos, chamados de "pavimentos de concreto compostos", são atualmente nomeados na Europa por "pavimentos verdes" 
$\mathrm{Na}$ Alemanha, existem inúmeras seções de pavimentos de concreto reciclados ao longo da rodovia A93 entre Brannenburg e Kiefersfelden, sendo esta rodovia de elevado tráfego servindo de principal ligação entre Munique e Insbruck, o maior corredor de ligação para o norte da Itália. O pavimento foi executado entre 1995 e 1996 tomando partido da reciclagem do concreto para a parte inferior de placas de concreto com espessura de $19 \mathrm{~cm}$ (a parte superior com $7 \mathrm{~cm}$ de agregados de diabásio de elevada qualidade e com funções de textura). Esta rodovia, após dez anos de intenso uso, não apresenta ainda sinais de degradação, apesar de baixíssimo nível de manutenção ocorrido (TOMPKINS et al., 2008).

Uma das principais diferenças do caso europeu com o americano consiste no fato de que na Europa os pavimentos são reciclados para constituição de novos pavimentos somente se não há presença de trincas $D$ (trincas devido à ação do gelo/degelo) e de reação álcali-sílica, devendo o pavimento de concreto antigo que estar em boas condições. Deve-se ter muito cuidado ao se utilizar pavimentos com esses defeitos para a obtenção de agregados para novos pavimentos, mas alguns projetos americanos mostraram que existem medidas que podem mitigar o potencial de recorrência destes.

O Departamento de Transportes de Minnesota (Mn/DOT), por exemplo, mostrou que a incorporação de cinza volante ao concreto pode reduzir consideravelmente a possibilidade de ocorrência de trincas de durabilidade (YRJANSON, 1989). Algumas seções construídas neste mesmo estado americano mostraram que pavimentos novos contendo agregados reciclados a partir de pavimentos apresentando trincas de durabilidade não apresentavam esse mesmo problema mesmo após 22 anos (seção Minnesota 2) e 26 anos (seção Minnesota 3) de utilização. No estado do Kansas também foi observada uma seção que mesmo após 9 anos não apresentava recorrência de trincas de durabilidade (GRESS et al., 2009). ${ }^{8}$

No que se refere à recorrência de reação álcali-agregado, como já foi dito, é possível diminuir esse efeito através de, entre outras medidas, o uso de materiais

\footnotetext{
${ }^{8}$ Deve-se ressaltar que o clima em Minnesota é marcado por temperaturas extremamente baixas e, portanto, a experiência em pavimentação deste local não é um parâmetro confiável para a realidade brasileira no que diz respeito à durabilidade.
} 
pozolânicos e de cimentos com escória de alto forno. O estudo de Gress et al. (2009) relata o caso de uma rodovia de Wyoming em que essas precauções permitiram que após 20 anos somente pequenas evidências de recorrência desse fenômeno fossem percebidas. Entretanto, a utilização de pavimentos que apresentem reação álcali-sílica como matéria prima para novos pavimentos deve ser feita com cuidado, pois apesar da possibilidade de se diminuir o problema, este ainda pode persistir. 


\section{ESTUDO COMPARATIVO: BRITADOR DE MANDÍBULA E BRITADOR DE IMPACTO}

\subsection{METODOLOGIA}

A primeira etapa experimental realizada foi o estudo comparativo entre as características apresentadas por agregados reciclados obtidos a partir do uso de britador de mandíbula e de britador de impacto, a fim de se definir qual método de britagem seria utilizado para a obtenção dos agregados a serem utilizados nos concretos.

\subsubsection{Material}

O concreto antigo utilizado é proveniente das placas de concreto do revestimento do pavimento do Rodoanel Metropolitano Mário Covas que apresentavam baixa condição de serventia (placas bailarinas e placas apresentando trincas e fissuras). Estas foram inicialmente quebradas em blocos com dimensão máxima de aproximadamente $50 \mathrm{~cm}$ por meio de uma perfuradora hidráulica. A seguir, uma pá carregadeira colocou os blocos em um caminhão basculante e o material foi levado à empresa Britex, onde passou por um processo de britagem primária em um britador de mandíbula. As Figuras 2.1 a 2.4 ilustram o pavimento de concreto do Rodoanel antes e depois de sua retirada.

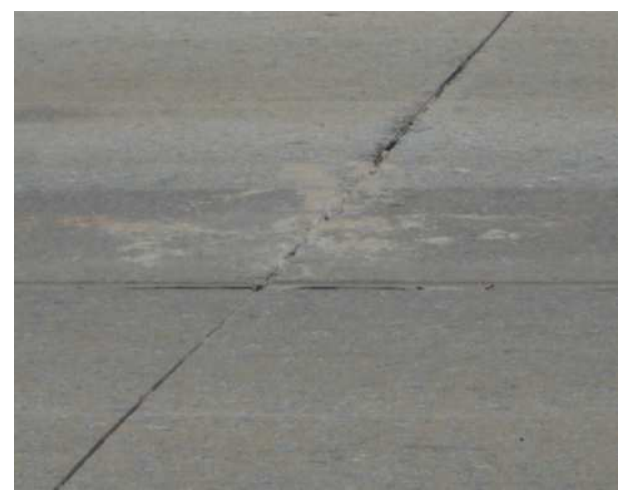

Figura 2.1 - Pavimento de concreto do Rodoanel

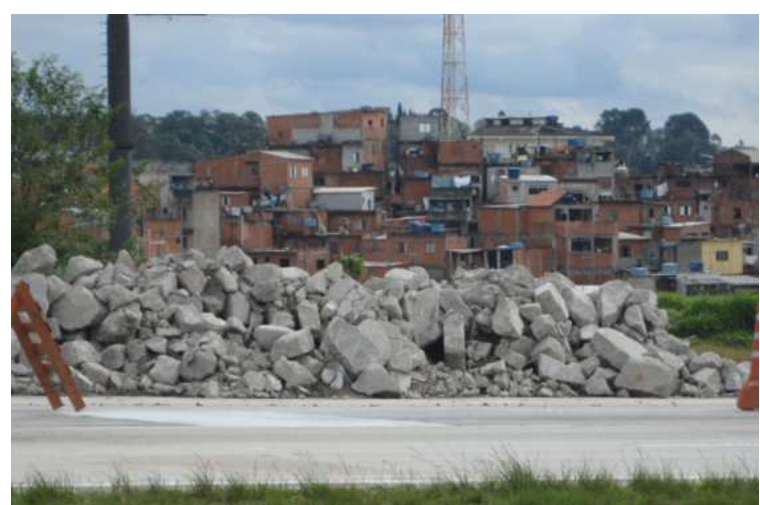

Figura 2.2 - Placas de concreto retiradas do Rodoanel 


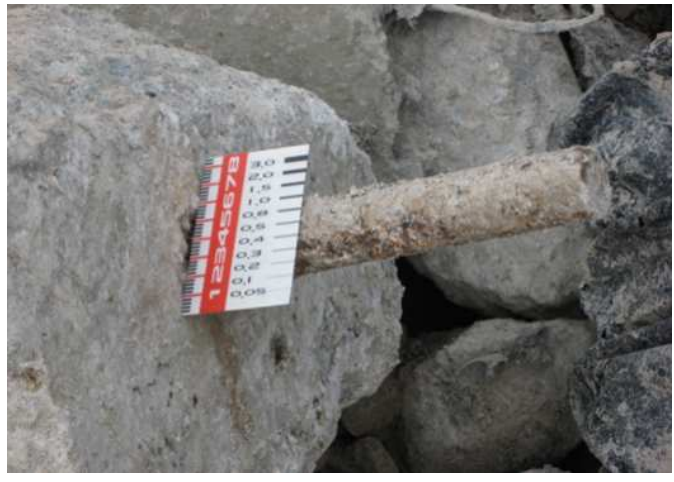

Figura 2.3 - Barra de transferência

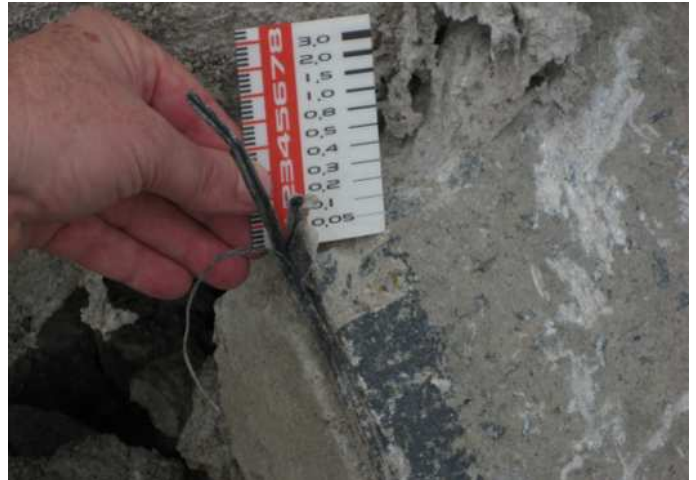

Figura 2.4 - Selante das juntas

As barras de aço e os selantes foram retirados manualmente por catação após a britagem. O material foi peneirado e dividido em 5 frações (Tabela 2.1), que seguiram através de esteiras rolantes formando 5 pilhas de materiais com granulometria distinta, conforme ilustrado nas Figuras 2.5 a 2.11.

Tabela 2.1 - Frações obtidas após britagem primária na Britex

\begin{tabular}{|c|c|}
\hline Fração & Quantidade aproximada (\% em massa) \\
\hline Rachão $(>25,0 \mathrm{~mm})$ & $\sim 40 \%$ \\
\hline Pedra 2 $(>12,5 \mathrm{~mm} \mathrm{e}<25,0 \mathrm{~mm})$ & $\sim 20 \%$ \\
\hline Pedra $1(>4,8 \mathrm{~mm} \mathrm{e}<12,5 \mathrm{~mm})$ & $\sim 13 \%$ \\
\hline Pedrisco com areia $(<4,8 \mathrm{~mm})$ & $\sim 13 \%$ \\
\hline Areia $(<2,0 \mathrm{~mm})$ & $\sim 13 \%$ \\
\hline
\end{tabular}

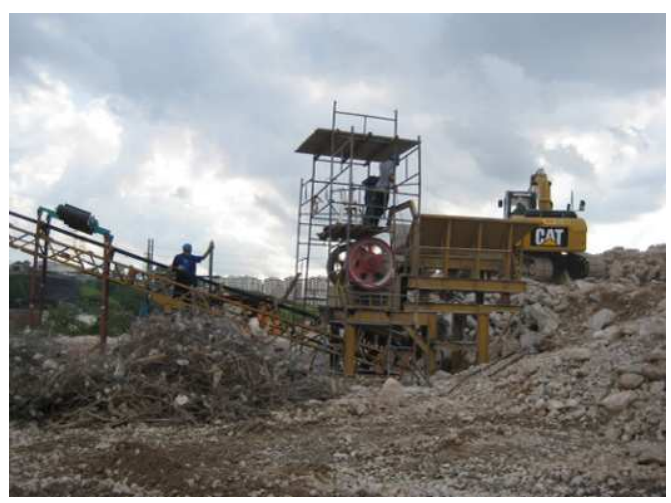

Figura 2.5 - Britador de mandíbula na Britex

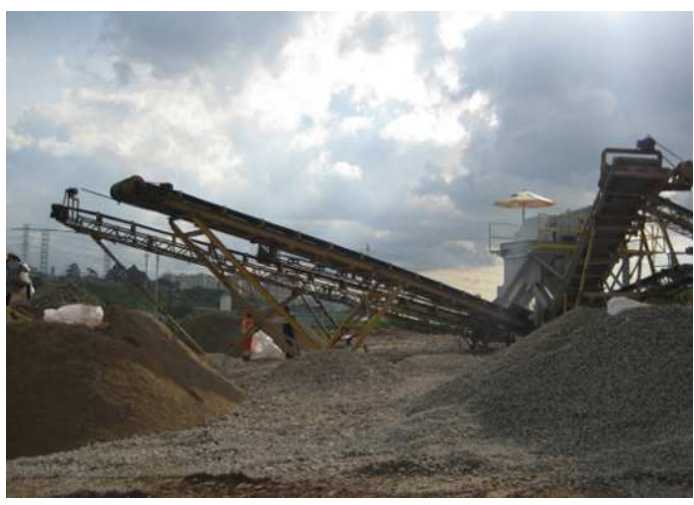

Figura 2.6 - Esteiras rolantes que levam o material às pilhas 


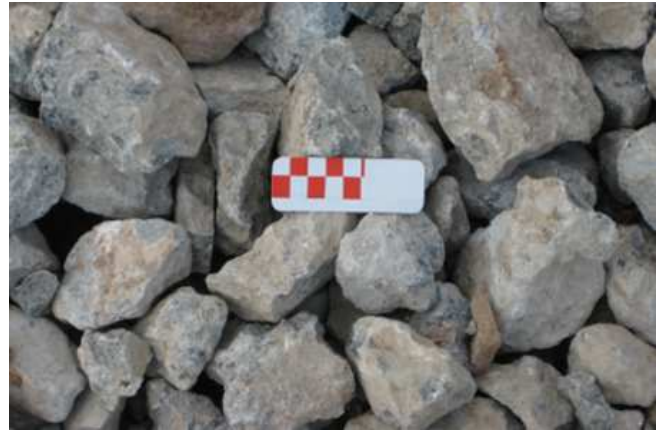

Figura 2.7 - Fração "rachão" obtida após britagem primária

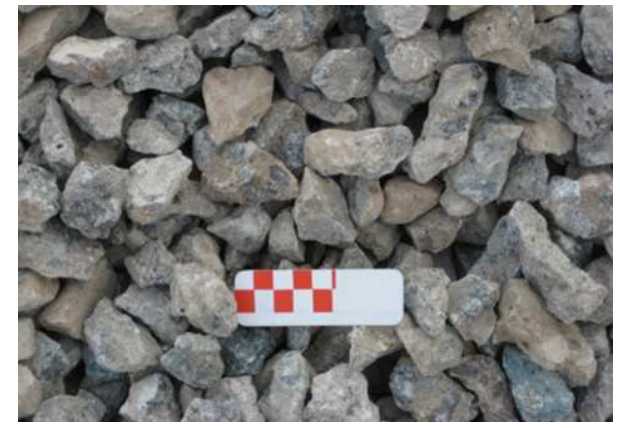

Figura 2.8 - Fração "pedra 2" obtida após britagem primária

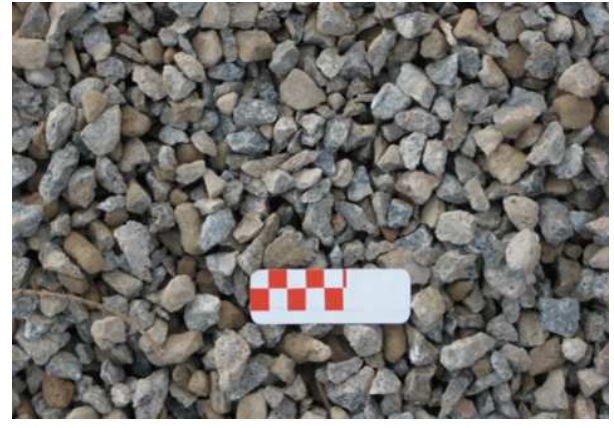

Figura 2.9 - Fração "pedra 1" obtida após britagem primária

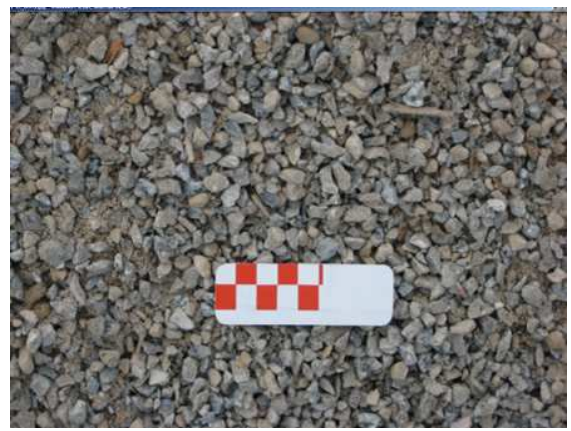

Figura 2.10 - Fração "pedrisco com areia" obtida após britagem primária

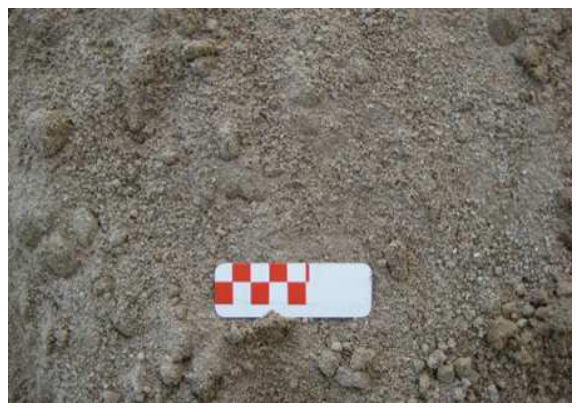

Figura 2.11 - Fração "areia” obtida após britagem primária

Após a britagem primária, o material com diâmetro superior a $25 \mathrm{~mm}$ foi separado para ser britado novamente, desta vez no LCT (Laboratório de Caracterização Tecnológica da Escola Politécnica da Universidade de São Paulo). Para o estudo comparativo entre métodos de britagem, o material foi cominuído através do britador de mandíbula (Figura 2.12) e de impacto (Figura 2.13) até se atingir 95\% de material passante na peneira de abertura $25 \mathrm{~mm}$. 


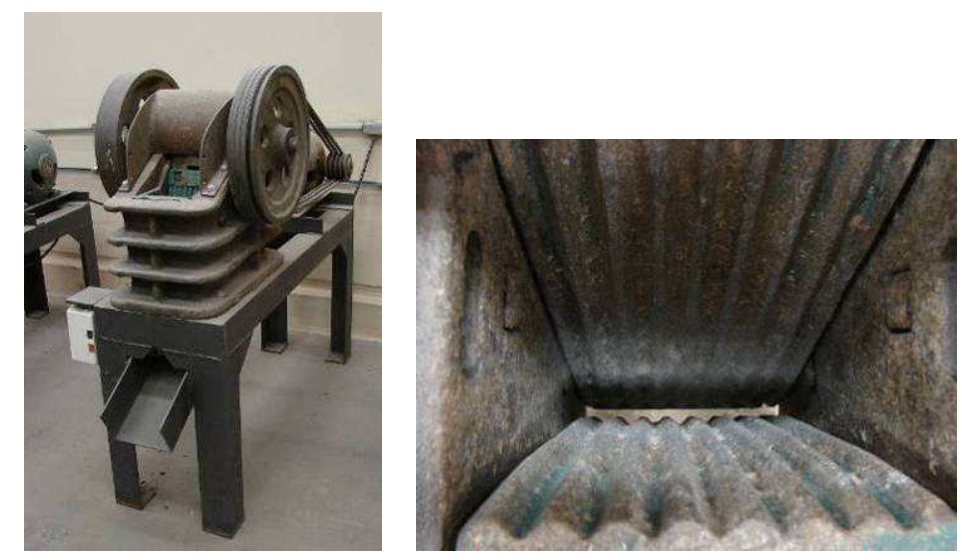

Figura 2.12 - Britador de mandíbula
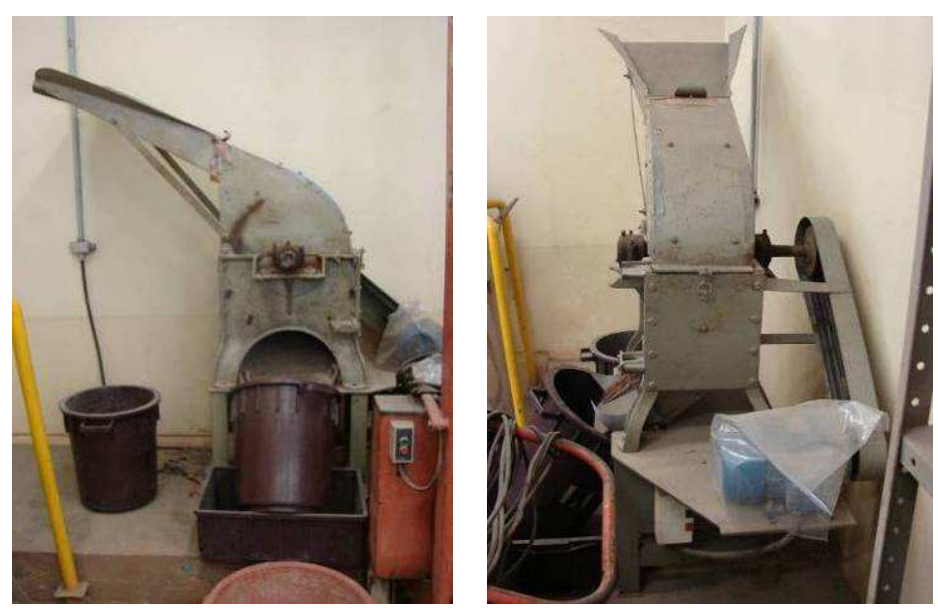

Figura 2.13 - Britador de impacto

\subsubsection{Amostragem}

Em todas as amostragens realizadas o material foi separado através de pilhas de homogeneização (Figura 2.14) ou de quarteador tipo Jones (Figura 2.15) a fim de se obter amostras representativas. Na pilha de homogeneização o material é distribuído uniformemente com baldes em uma pilha alongada, alternando-se o sentido de início e final de despejo do balde na pilha. Após esse processo as extremidades são recolhidas e despejadas novamente. Finalizada a pilha, as alíquotas de material são retiradas dividindo-se a pilha em frações volumétricas semelhantes. Já no quarteador tipo Jones os agregados são despejados pela parte superior do quarteador e este os divide em duas porções semelhantes. O processo é repetido até que toda amostra seja dividida igualmente. 

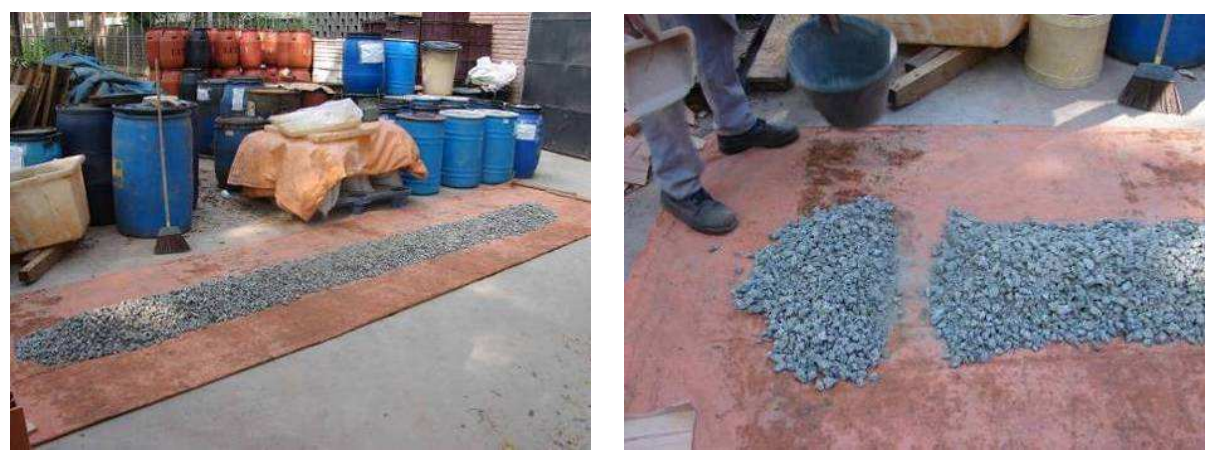

Figura 2.14 - Pilha de homogeneização
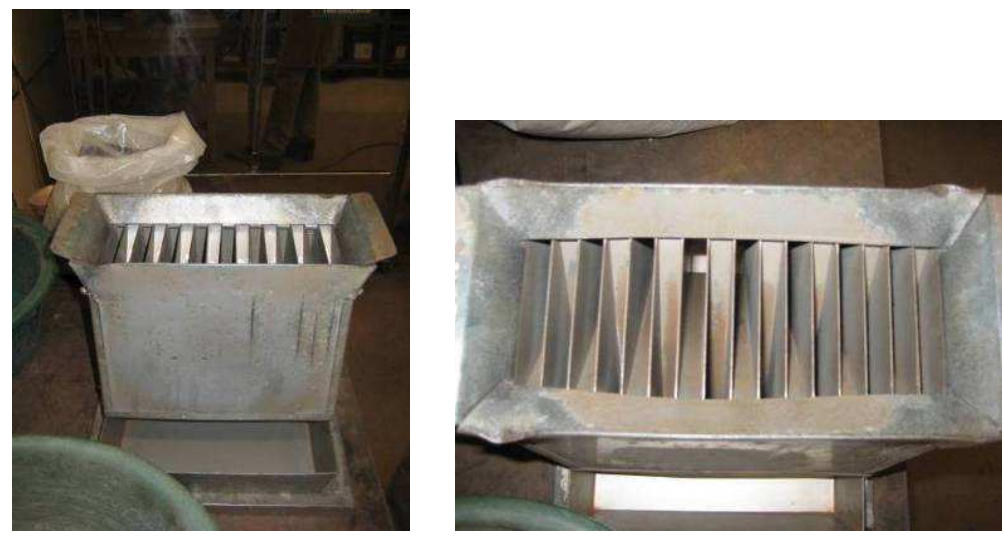

Figura 2.15 - Quarteador tipo Jones

\subsubsection{Formato dos grãos}

A fim de se analisar o formato dos grãos obtidos com o uso dos diferentes tipos de britadores não foi seguida nenhuma norma em sua integridade, porém, foram considerados aspectos da norma ABNT NBR 7809 (1983) e do método IPT M-49 descrito por Yoshida et al. (1972).

Primeiramente as amostras foram homogeneizadas de maneira a se obter o número de grãos a serem medidos em cada faixa granulométrica estudada segundo a eq.(14) definida pela ABNT NBR 7809 (1983).

$$
N=\frac{200}{F_{1}+F_{2}+F_{3}+\ldots .+F_{i}+\ldots .+F_{n}} x F_{i}
$$

onde:

200: número de grãos necessários para o ensaio; 
N: número de grãos para a medição da fração i;

$F_{i}(\%)$ : porcentagem de massa da fração;

$\mathrm{F}_{1}+\mathrm{F}_{2}+\mathrm{F}_{3}+\ldots+\mathrm{F}_{i}+\ldots+\mathrm{F}_{\mathrm{n}}(\%)$ : soma das porcentagens em peso retidas individualmente das frações obtidas.

Para cada partícula foram feitas 3 medições ortogonais entre si: 'a' (maior dimensão), 'b' (dimensão intermediária) e 'c' (menor dimensão). A seguir foram calculadas as médias dos valores de b/c e c/b para cada fração e tipo de britagem adotado, classificando-se os agregados segundo a Tabela 2.2 (método IPT-M-49). Quanto maior o valor de b/a obtido mais lamelar a partícula se apresenta, e quanto maior o valor de c/b obtido mais alongada ela se apresenta.

Tabela 2.2 - Classificação da forma (Yoshida et al., 1972)

\begin{tabular}{|c|c|}
\hline Relações médias de $\mathbf{b} / \mathbf{a}$ e c $/ \mathbf{b}$ & Classificação da forma \\
\hline $\mathrm{b} / \mathrm{a}>0,5$ e $\mathrm{c} / \mathrm{b}>0,5$ & cúbica \\
\hline $\mathrm{b} / \mathrm{a}<0,5$ e $\mathrm{c} / \mathrm{b}>0,5$ & alongada \\
\hline $\mathrm{b} / \mathrm{a}>0,5$ e $\mathrm{c} / \mathrm{b}<0,5$ & lamelar \\
\hline $\mathrm{b} / \mathrm{a}<0,5$ e $\mathrm{c} / \mathrm{b}<0,5$ & alongada-lamelar \\
\hline
\end{tabular}

\subsubsection{Abrasão Los Angeles}

O ensaio de abrasão "Los Angeles" foi realizado conforme as instruções da norma DNER-ME 035 (1998), no Laboratório de Tecnologia em Pavimentação da EPUSP. Foram utilizadas amostras de graduação B definidas pelo DNER, isto é, compostas de $2.500 \pm 10 \mathrm{~g}$ de material passando na peneira de abertura $19 \mathrm{~mm}$ e retido na peneira de abertura $12,5 \mathrm{~mm}$ e $2.500 \pm 10 \mathrm{~g}$ de material passando na peneira de abertura $12,5 \mathrm{~mm}$ e retido na peneira de abertura $9,5 \mathrm{~mm}$. A máquina e as esferas utilizadas no ensaio são apresentadas na Figura 2.16. 

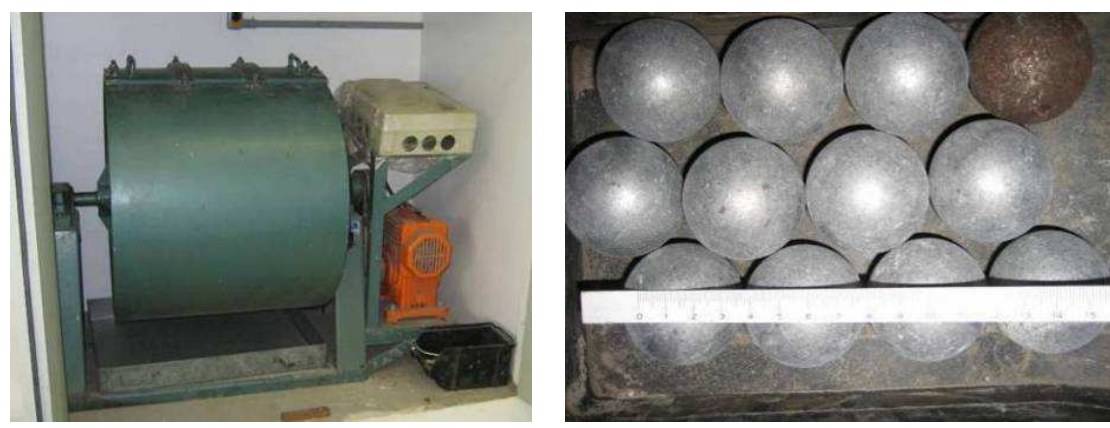

Figura 2.16 - Máquina e esferas metálicas utilizadas no ensaio de abrasão "Los Angeles"

\subsubsection{Absorção de água}

Os ensaios de determinação de absorção de água dos agregados foram feitos no LCT segundo as normas ABNT NBR NM 30 (2001), para os agregados miúdos, e ABNT NBR NM 53 (2003), para os agregados graúdos (Figura 2.17). Para tal, os agregados foram separados em diversas faixas granulométricas.

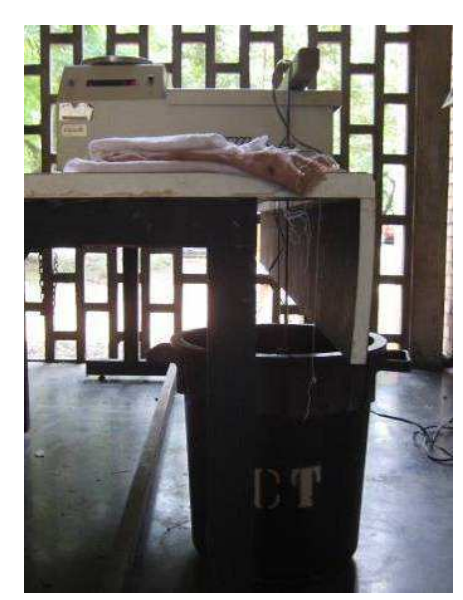

Figura 2.17 - Montagem de equipamento para realização do ensaio de absorção de agregados graúdos

\subsubsection{Caracterização química}

A análise química foi feita a partir de amostras obtidas pelo britador de impacto e pelo britador de mandíbula para o estudo comparativo entre métodos de britagem. Foi utilizada a técnica de espectrometria de fluorescência de raios $X$ (FRX), utilizando o espectrômetro Magix Pro da PANalytical (Figura 2.18), no LCT. 


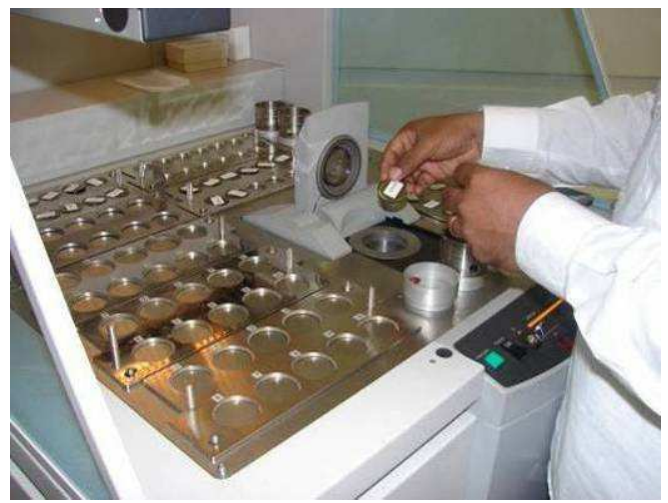

Figura 2.18 - Espectrômetro Magix Pro da PANalytical (foto cedida pelo LCT)

A preparação do material envolveu as seguintes etapas:

- Cominuição em moinho de rolos da marca Furlan, modelo S90L4, até obtenção de partículas de diâmetro máximo abaixo de 1 mm (Figura 2.19).
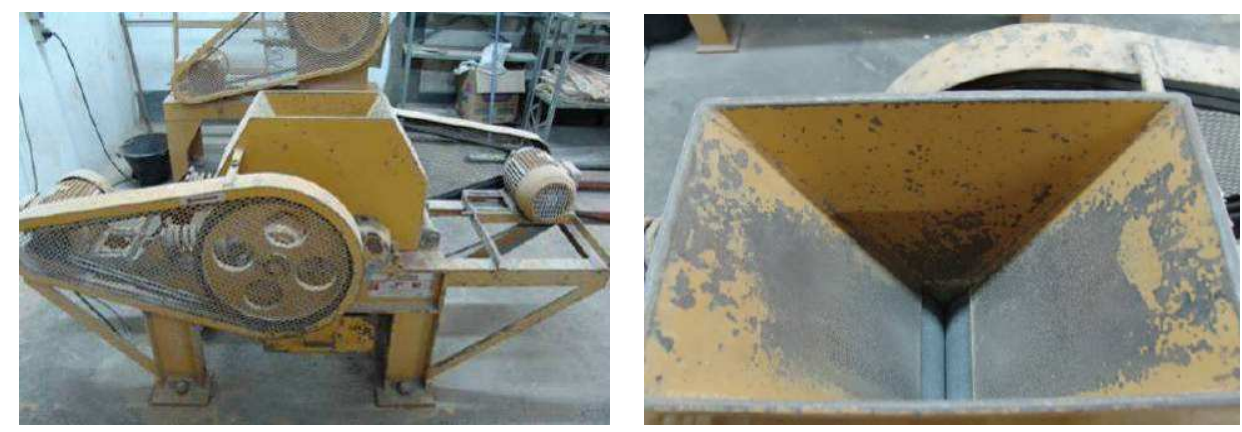

Figura 2.19 - Moinho de rolos (ULSEN, 2006)

- Pulverização em moinhos de discos oscilantes, Herzog HSM 250P (Figura 2.20) até obtenção de partículas de diâmetro máximo $20 \mu \mathrm{m}$.
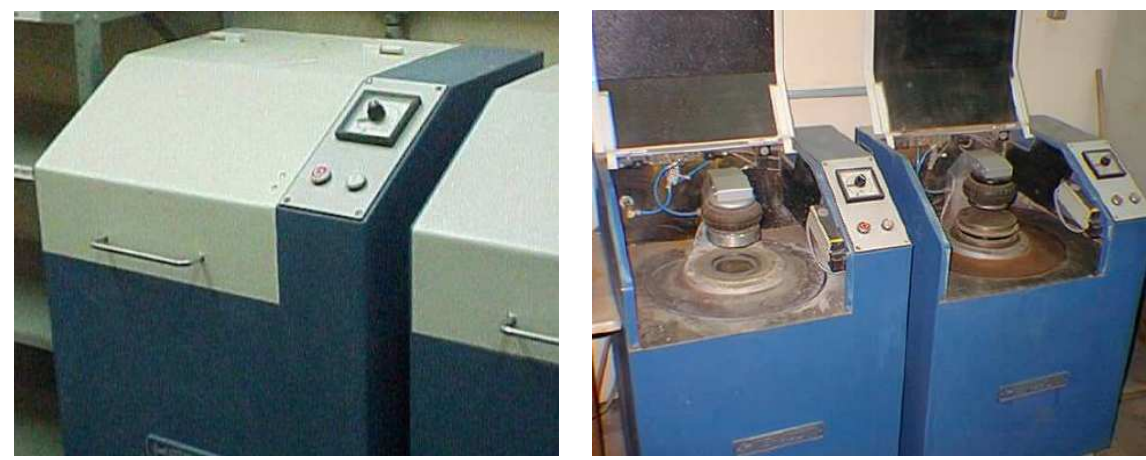

Figura 2.20 - Moinho de discos oscilantes (ULSEN, 2006) 
- Confecção de pastilhas a partir da fusão de amostras (Figura 2.21)

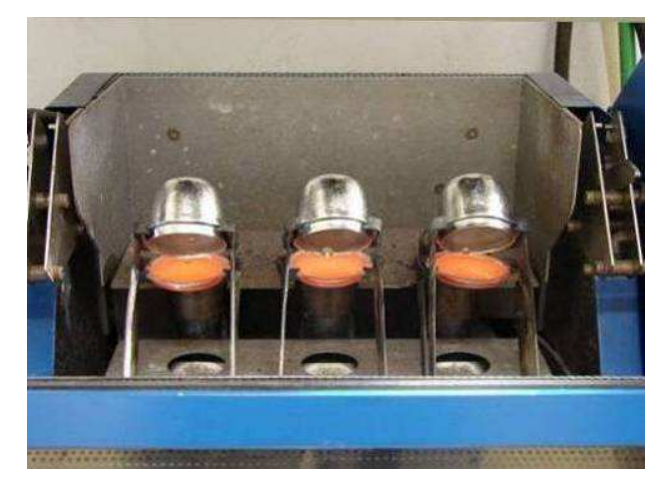

Figura 2.21 - Máquina de fusão (foto cedida pelo LCT)

\subsection{APRESENTAÇÃO E DISCUSSÃO DOS RESULTADOS}

\subsubsection{Distribuição granulométrica}

A seguir são apresentadas as curvas granulométricas obtidas. A Figura 2.22 corresponde a todo o material gerado com o uso do britador de mandíbula ou de impacto, a Figura 2.23 corresponde às curvas granulométricas somente das frações retidas na peneira $4,8 \mathrm{~mm}$, e a Figura 2.24 corresponde ao material passante na peneira 4.8. A partir das curvas obtidas é possível concluir que os dois métodos de britagem produzem agregados miúdos e graúdos em proporções muito similares. No britador de mandíbula a porcentagem de agregados graúdos produzida foi de $85 \%$, enquanto no britador de impacto foi de $82 \%$, ou seja, a eficiência na produção de agregados graúdos foi levemente superior com o uso de britador de mandíbula.

Tanto no caso dos agregados graúdos como no caso dos miúdos, a distribuição granulométrica obtida é muito semelhante, não sendo este um fator decisivo para a escolha do tipo de britador a ser utilizado. No caso dos agregados miúdos, observase que as partículas geradas com o uso do britador de mandíbula possuem, no geral, dimensões ligeiramente menores que aquelas produzidas pelo britador de impacto. 


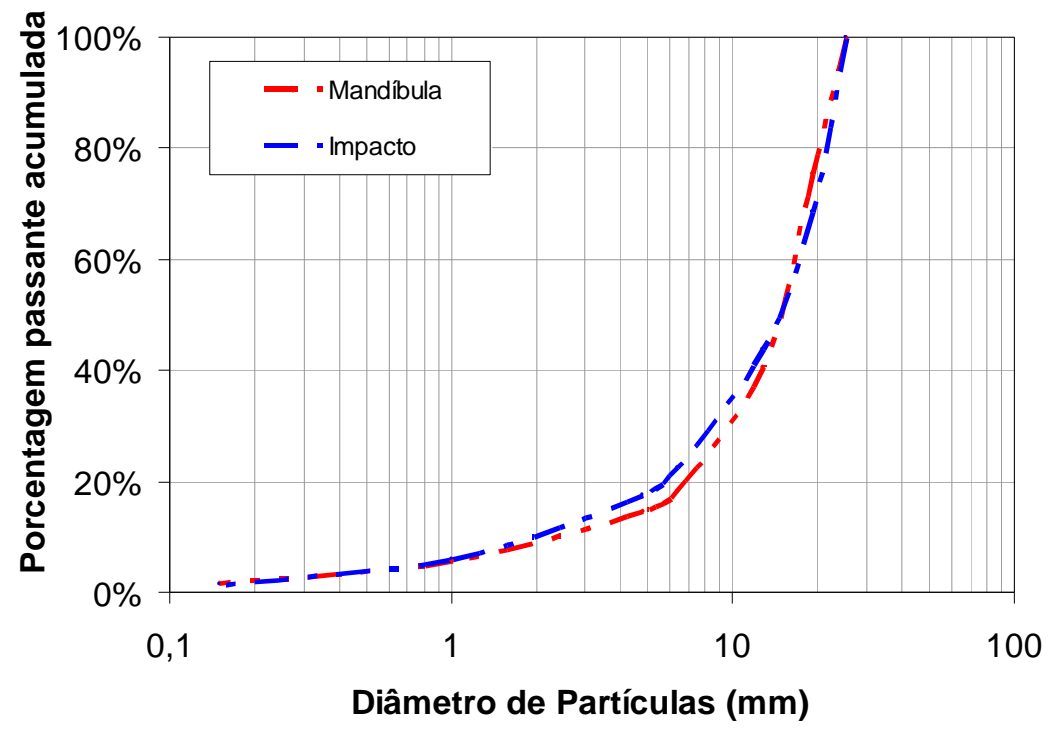

Figura 2.22 - Curvas granulométricas dos agregados segundo o método de britagem utilizado

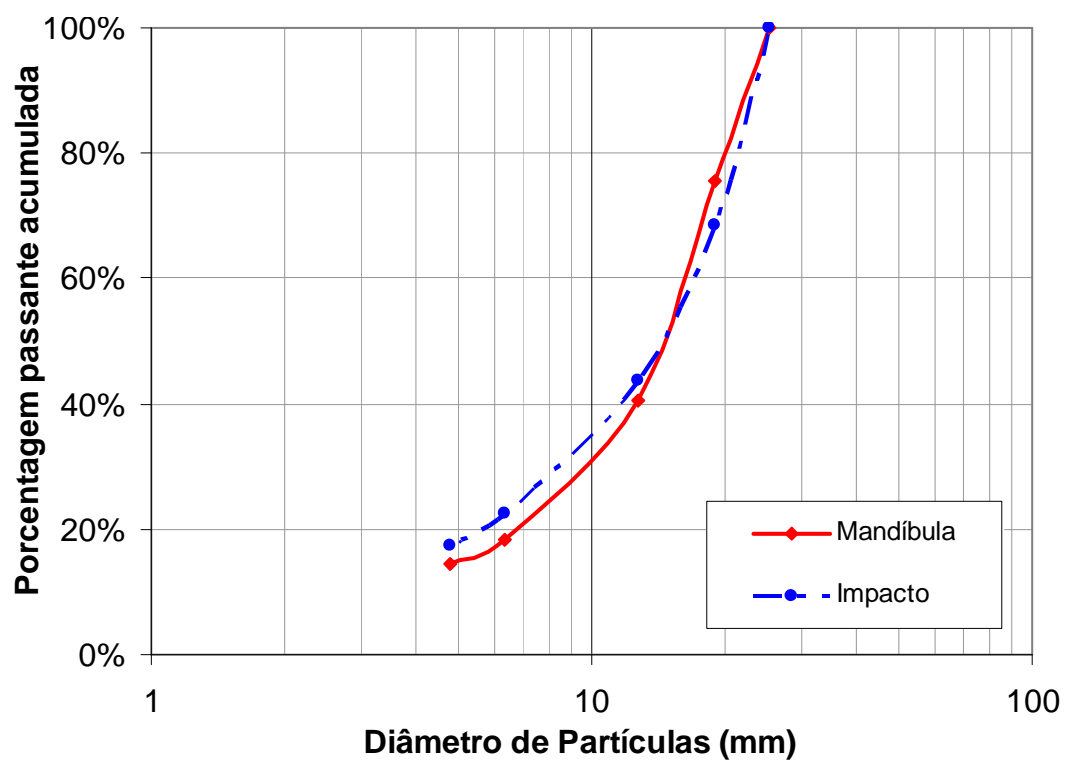

Figura 2.23 - Curvas granulométricas dos agregados graúdos segundo o método de britagem utilizado 


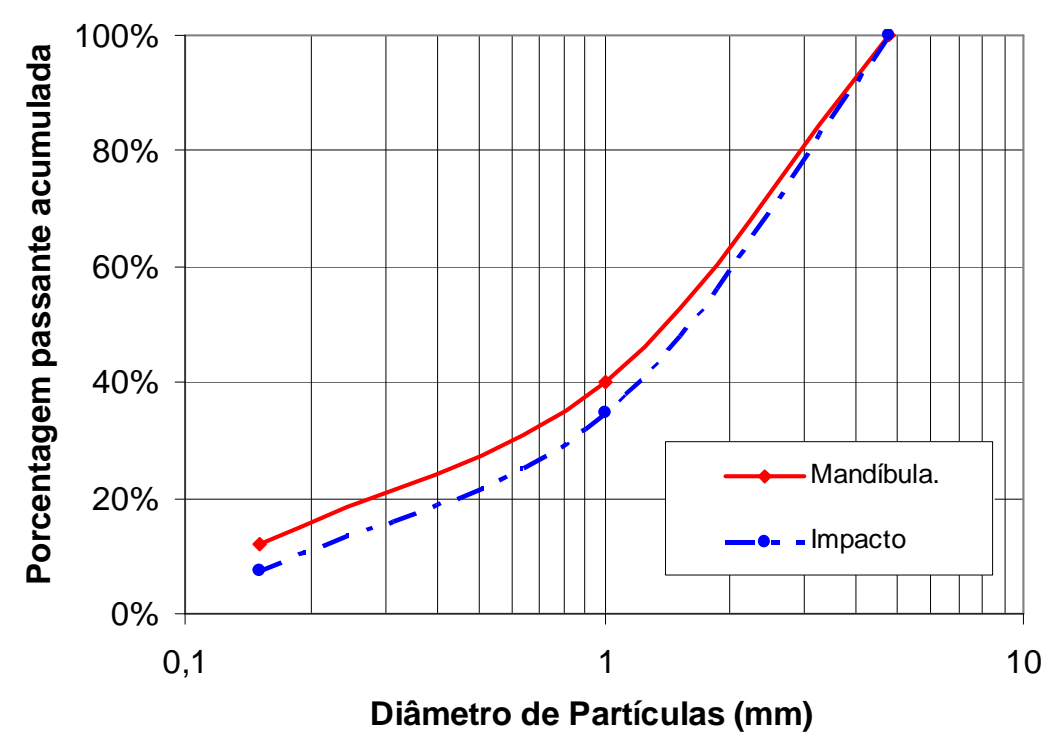

Figura 2.24 - Curvas granulométricas dos agregados miúdos obtidos segundo o método de britagem utilizado

2.2.2 Absorção, massa específica aparente e porosidade aparente dos agregados graúdos

Os resultados médios dos ensaios de absorção de água por parte dos agregados, bem como o máximo e mínimo encontrado, são apresentados nas Figuras 2.25 a 2.27. Pela proximidade dos valores obtidos concluí-se que os dois métodos de britagem produzem agregados muito semelhantes quanto à absorção, à porosidade aparente e à massa específica aparente. A absorção de água dos agregados retidos na peneira de abertura $6,3 \mathrm{~mm}$ é levemente mais elevada nos agregados obtidos através do britador de mandíbula. 


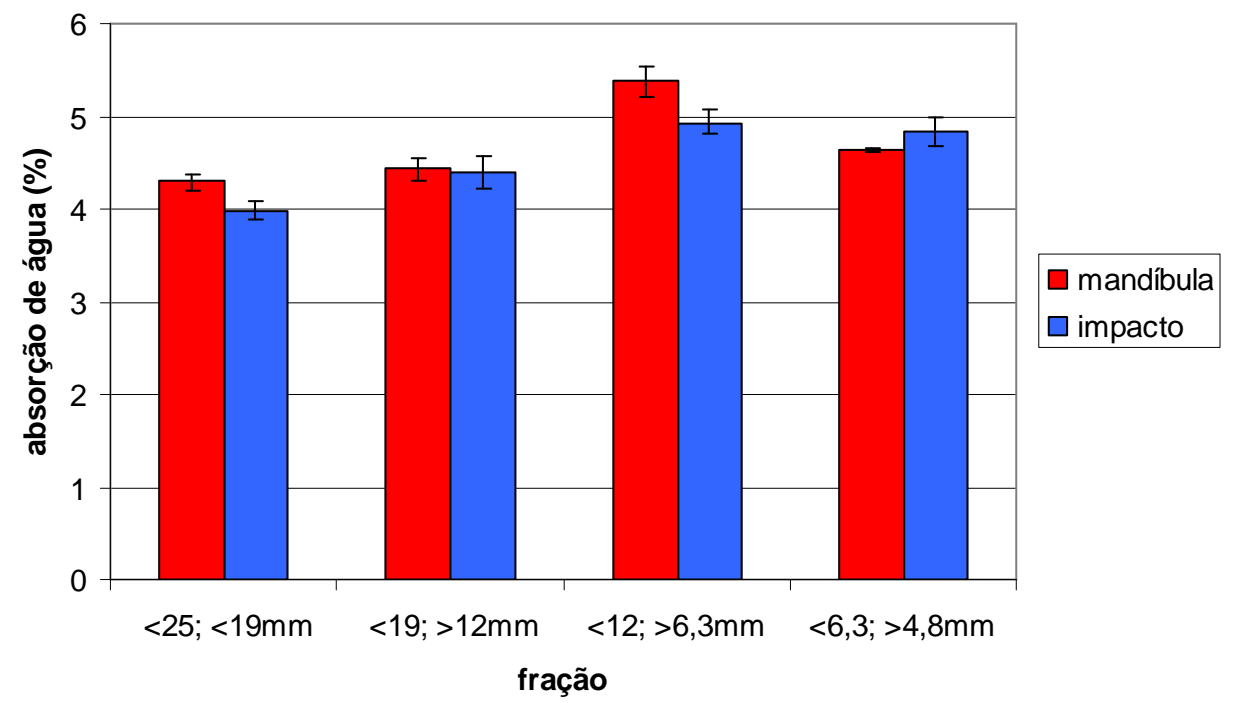

Figura 2.25 - Absorção de água dos agregados graúdos por fração e tipo de britagem

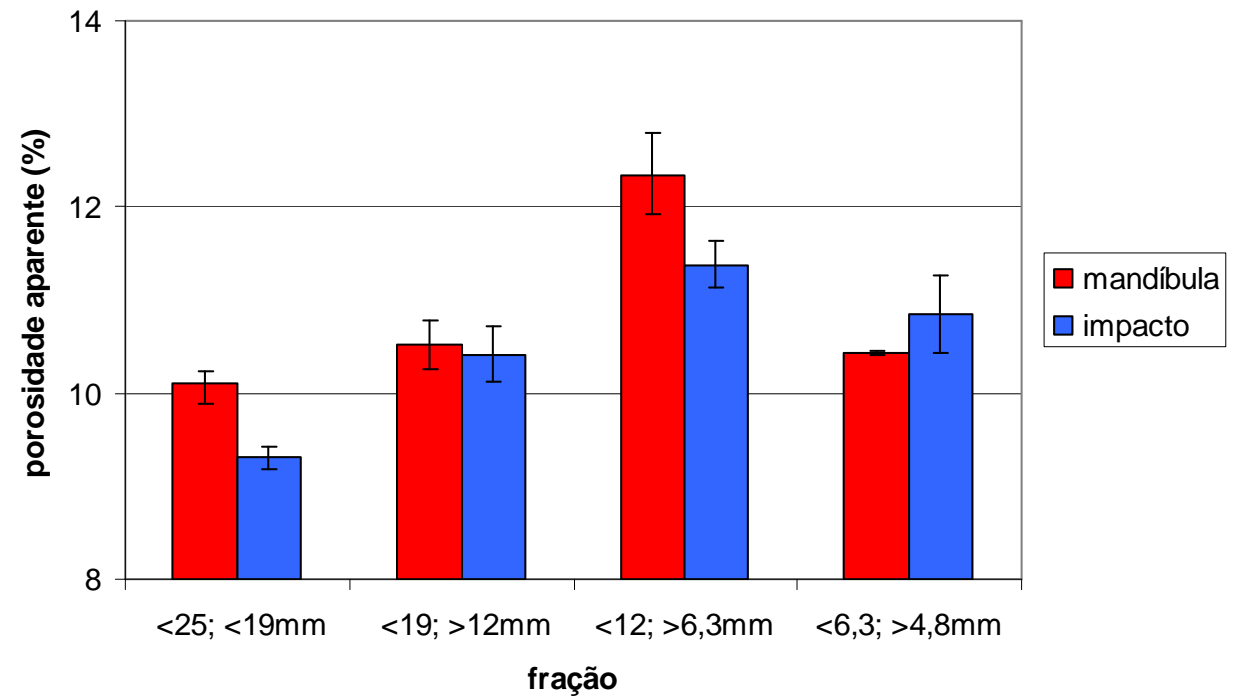

Figura 2.26 - Porosidade aparente dos agregados graúdos por fração e tipo de britagem 


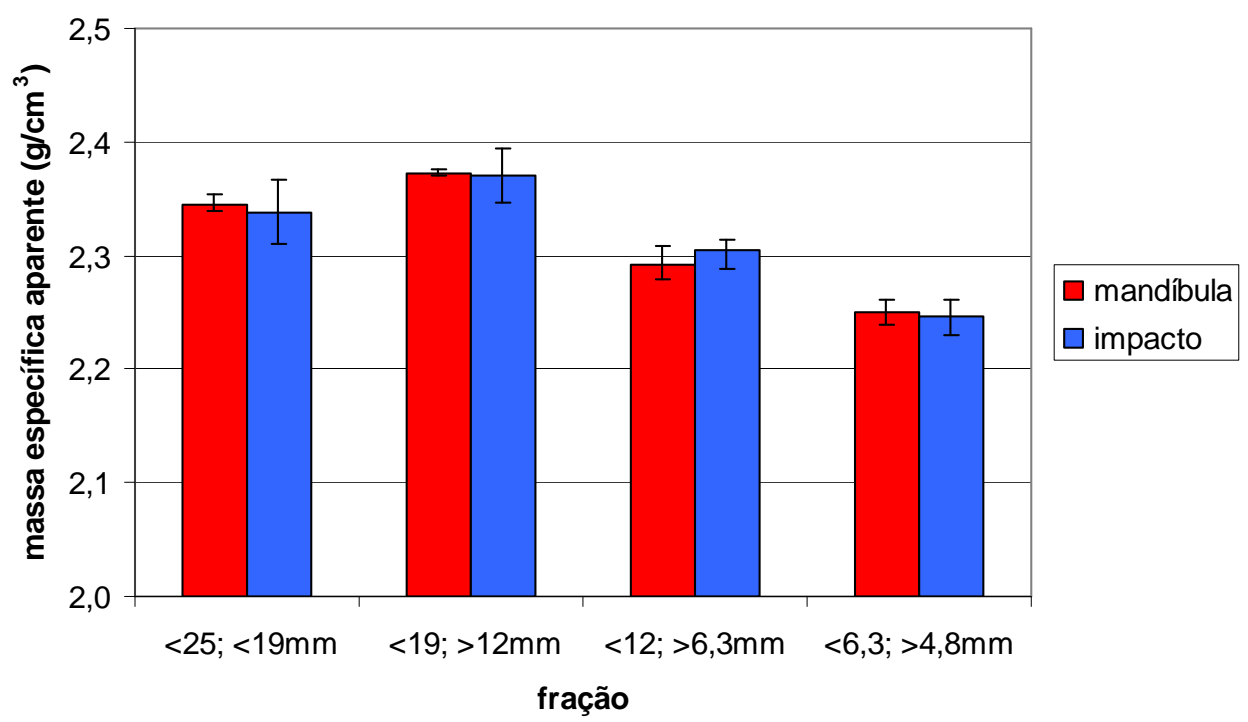

Figura 2.27 - Massa específica aparente dos agregados graúdos por fração e tipo de britagem

Nota-se, também, pelos resultados apresentados nesse ensaio, que para ambos os tipos de britagem o agregado obtido apresenta menor massa específica aparente e maior absorção de água nas frações menores; confirmando que quanto menores as dimensões das partículas maior é a quantidade de pasta de cimento presente.

\subsubsection{Abrasão Los Angeles}

Na Tabela 2.3 são apresentados os resultados obtidos no ensaio de resistência à abrasão. O resultado revela que o índice de abrasão "Los Angeles" é maior para os agregados britados através do britador de impacto; entretanto ambos permanecem dentro dos limites estipulados pela norma ABNT NBR 7211 (1983), que limita o índice de abrasão "Los Angeles" em 50\% para agregados a serem utilizados em concreto.

Tabela 2.3 - Resultados do ensaio de abrasão "Los Angeles"

\begin{tabular}{lcc}
\hline & Britador de Mandíbula & Britador de Impacto \\
\hline abrasão "Los Angeles" (\%) & 32 & 43 \\
\hline
\end{tabular}

Uma possível explicação para a diferença observada seria a presença de maior quantidade de pasta aderida nos agregados produzidos através de britagem por impacto, que deixariam o agregado mais suscetível a perda de material por abrasão. 
A menor absorção de água apresentada pelos agregados obtidos através do britador de impacto pode ser explicada pelo modo de quebra dos agregados nos diferentes tipos de britadores. O britador de impacto quebra as partículas nas fraquezas estruturais pré-existentes (planos e interfaces de menor resistência, micro-fraturas e contornos de grão), ou seja, diminui o volume de defeitos no agregado; enquanto o britador de mandíbula quebra as partículas por cisalhamento no plano principal de tensões (45ำ com a direção da compressão) podendo aumentar a quantidade de defeitos (CHAVES e PERES, 1999; CHAVES e. al., 2006). Dessa maneira, apesar do agregado conter menor quantidade de pasta, poderia apresentar-se mais poroso.

\subsubsection{Análise química}

Os resultados da análise química feita para as diversas frações dos agregados obtidos através de britador de impacto e de mandíbula são apresentados nas Figuras 2.28 e 2.29 e nas Tabelas 2.4 e 2.5 .

No caso de não se utilizarem agregados naturais calcários, como é o caso deste estudo, a perda ao fogo e o teor de cálcio estão relacionados à presença de pasta de cimento (ULSEN, 2006). Observa-se uma leve tendência do agregado obtido por britador de impacto possuir maior teor de $\mathrm{CaO}+\mathrm{PF}$ e menor teor de $\mathrm{SiO}_{2}$ que o agregado obtido por britador de mandíbula, o que sugere que o primeiro apresenta em sua composição maior proporção de pasta de cimento aderida, confirmando as suposições feitas a partir do resultado do ensaio de abrasão.

Além disso, deve-se observar que a análise química confirma mais uma vez que as frações de dimensões menores possuem a tendência de apresentar maior quantidade de pasta de cimento antiga (quanto menores as frações menor é a quantidade de $\mathrm{SiO}_{2}$ e maior a quantidade de $\mathrm{CaO}+\mathrm{PF}$ encontradas). 


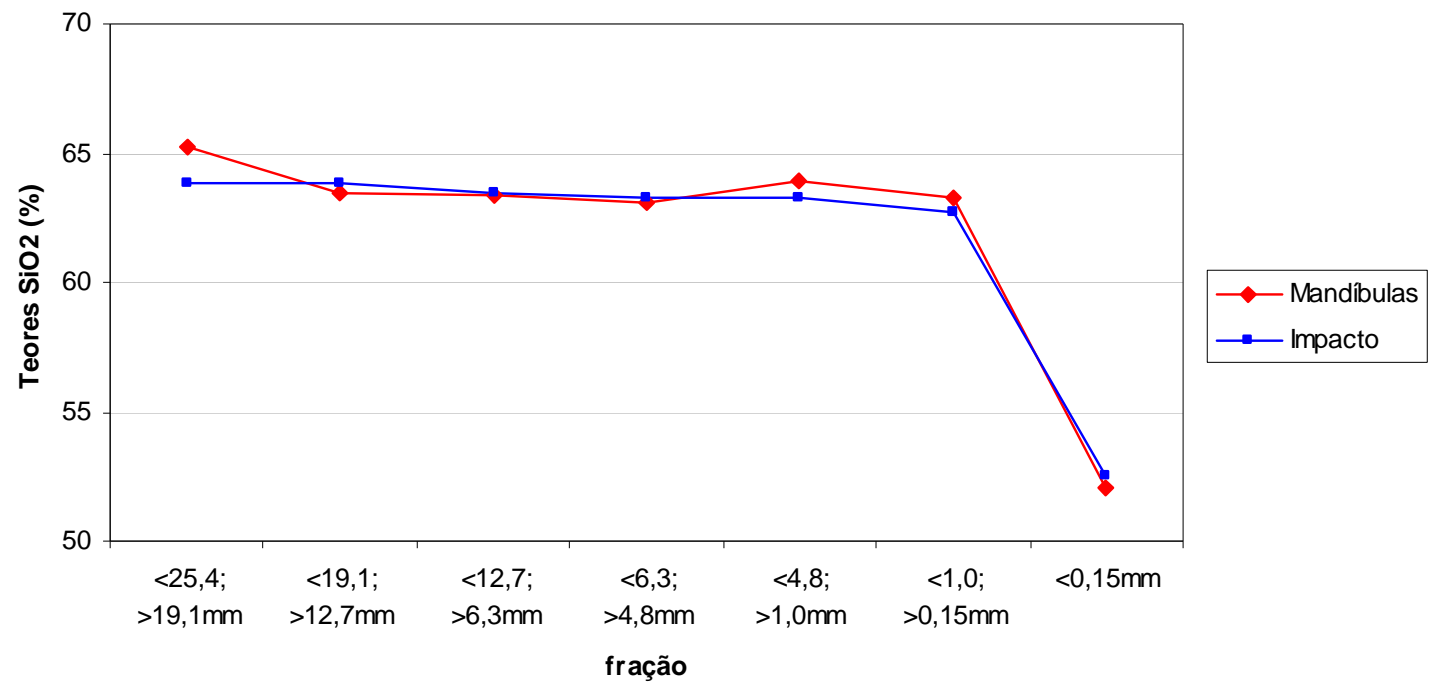

Figura 2.28 - Teor de $\mathrm{SiO}_{2}$ nas amostras obtidas através de britador de impacto e de mandíbula

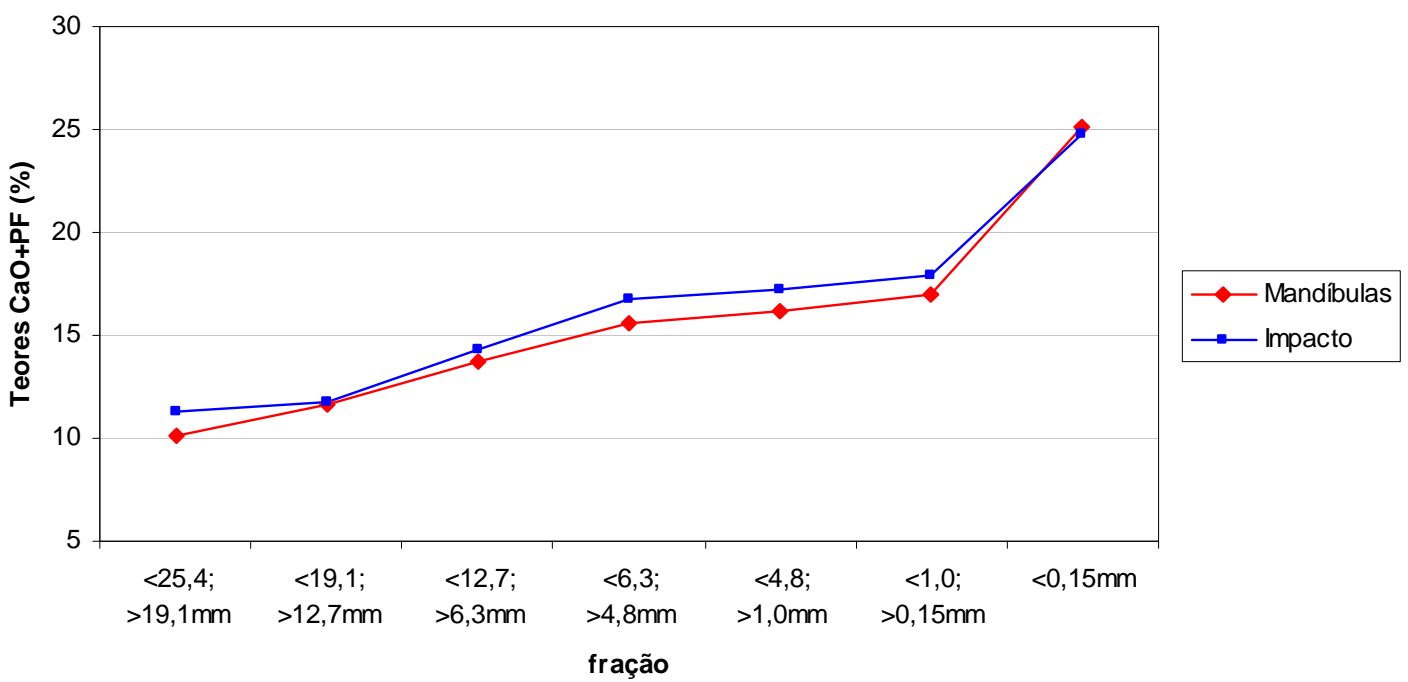

Figura 2.29 - Teor de $\mathrm{CaO}$ + perda ao fogo nas amostras obtidas através de britador de impacto e de mandíbula 
Tabela 2.4 - Análise química dos agregados obtidos através do britados de mandíbula

\begin{tabular}{|c|c|c|c|c|c|c|c|c|c|c|c|c|c|c|c|}
\hline & \multirow{2}{*}{ Amostra } & \multirow{2}{*}{$\begin{array}{c}\text { Massa } \\
(\%)\end{array}$} & \multicolumn{13}{|c|}{ Teores de óxidos (\% em massa) } \\
\hline & & & $\mathrm{SiO}_{2}$ & $\mathrm{Al}_{2} \mathrm{O}_{3}$ & $\mathrm{Fe}_{2} \mathrm{O}_{3}$ & $\mathrm{CaO}$ & $\mathrm{PF}$ & $\mathrm{MnO}$ & MgO & $\mathrm{Na}_{2} \mathrm{O}$ & $\mathrm{K}_{2} \mathrm{O}$ & $\mathrm{TiO}_{2}$ & $\mathrm{P}_{2} \mathrm{O}_{5}$ & Si+Al & $\mathrm{Ca}+\mathrm{PF}$ \\
\hline \multirow{7}{*}{ 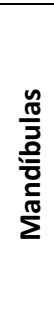 } & $<25.4 ;>19.1 \mathrm{~mm}$ & $24,4 \%$ & 65,2 & 12,3 & 3,62 & 8,52 & 1,60 & 0,16 & 1,36 & 2,12 & 3,62 & 0,50 & 0,18 & 77,5 & 10,1 \\
\hline & $<19.1 ;>12.7 \mathrm{~mm}$ & $35,0 \%$ & 63,5 & 12,1 & 3,97 & 8,66 & 2,96 & 0,17 & 1,35 & 2,10 & 3,53 & 0,49 & 0,17 & 75,6 & 11,6 \\
\hline & $<12.7 ;>+6.3 \mathrm{~mm}$ & $22,2 \%$ & 63,3 & 11,2 & 3,77 & 9,73 & 3,99 & 0,18 & 1,35 & 1,86 & 3,35 & 0,46 & 0,16 & 74,5 & 13,7 \\
\hline & $<6.3 ;>4.8 \mathrm{~mm}$ & $3,8 \%$ & 63,1 & 10,3 & 3,46 & 11,1 & 4,46 & 0,21 & 1,34 & 1,60 & 3,17 & 0,42 & 0,14 & 73,3 & 15,6 \\
\hline & $<4.8 ;>1.0 \mathrm{~mm}$ & $8,8 \%$ & 63,9 & 9,53 & 3,25 & 11,6 & 4,57 & 0,23 & 1,29 & 1,32 & 3,00 & 0,38 & 0,11 & 73,4 & 16,2 \\
\hline & $<1.0 ;>0.15 \mathrm{~mm}$ & $4,1 \%$ & 63,2 & 9,16 & 3,42 & 12,4 & 4,63 & 0,22 & 1,57 & 1,10 & 2,81 & 0,44 & 0,10 & 72,4 & 17,0 \\
\hline & $<0.15 \mathrm{~mm}$ & $1,8 \%$ & 52,0 & 10,6 & 4,39 & 17,3 & 7,78 & 0,24 & 1,98 & 1,10 & 2,83 & 0,61 & 0,41 & 62,6 & 25,1 \\
\hline
\end{tabular}

Tabela 2.5 - Análise química dos agregados obtidos através do britados de impacto

\begin{tabular}{|c|c|c|c|c|c|c|c|c|c|c|c|c|c|c|c|}
\hline & \multirow{2}{*}{ Amostra } & \multirow{2}{*}{$\begin{array}{c}\text { Massa } \\
\text { (\%) }\end{array}$} & \multicolumn{13}{|c|}{ Teores de óxidos (\% em massa) } \\
\hline & & & $\mathrm{SiO}_{2}$ & $\mathrm{Al}_{2} \mathrm{O}_{3}$ & $\mathrm{Fe}_{2} \mathrm{O}_{3}$ & $\mathrm{CaO}$ & PF & $\mathrm{MnO}$ & MgO & $\mathrm{Na}_{2} \mathrm{O}$ & $\mathrm{K}_{2} \mathrm{O}$ & $\mathrm{TiO}_{2}$ & $\mathrm{P}_{2} \mathrm{O}_{5}$ & Si+Al & $\mathrm{Ca}+\mathrm{PF}$ \\
\hline \multirow{7}{*}{ 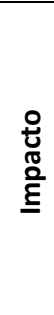 } & $<25.4 ;>19.1$ & $31,4 \%$ & 63,8 & 12,1 & 3,92 & 8,60 & 2,65 & 0,16 & 1,35 & 2,09 & 3,65 & 0,50 & 0,17 & 75,9 & 11,2 \\
\hline & $<19.1 ;>12.7 \mathrm{~mm}$ & $24,7 \%$ & 63,9 & 11,9 & 3,86 & 8,83 & 2,94 & 0,17 & 1,33 & 2,10 & 3,56 & 0,49 & 0,18 & 75,8 & 11,8 \\
\hline & $<12.7 ;>6.3 \mathrm{~mm}$ & $21,4 \%$ & 63,5 & 11,3 & 3,55 & 10,3 & 4,02 & 0,18 & 1,33 & 1,90 & 3,42 & 0,46 & 0,15 & 74,8 & 14,3 \\
\hline & $<6.3 ;>4.8 \mathrm{~mm}$ & $4,9 \%$ & 63,2 & 10,2 & 3,09 & 11,7 & 5,09 & 0,18 & 1,36 & 1,55 & 3,19 & 0,42 & 0,13 & 73,5 & 16,8 \\
\hline & $<4.8 ;>1.0 \mathrm{~mm}$ & $11,5 \%$ & 63,3 & 9,46 & 3,35 & 12,2 & 5,04 & 0,24 & 1,28 & 1,32 & 3,04 & 0,37 & 0,12 & 72,8 & 17,2 \\
\hline & $<1.0 ;>0.15 \mathrm{~mm}$ & $4,8 \%$ & 62,7 & 8,81 & 3,53 & 12,5 & 5,42 & 0,22 & 1,47 & 1,09 & 2,73 & 0,40 & 0,11 & 71,5 & 18,0 \\
\hline & $<0.15 \mathrm{~mm}$ & $1,3 \%$ & 52,5 & 10,4 & 4,91 & 16,2 & 8,63 & 0,30 & 1,89 & 1,12 & 2,75 & 0,60 & 0,25 & 62,9 & 24,8 \\
\hline
\end{tabular}




\subsubsection{Formato dos grãos}

São apresentados nas Tabelas 2.6 e 2.7 os resultados obtidos a partir da medição das dimensões do agregado graúdo e da classificação segundo a recomendação adotada. Pode-se concluir que a diferença entre o formato dos grãos não é acentuada, sendo ambos considerados como cúbicos.

Tabela 2.6 - Índices de forma e classificação dos agregados obtidos a partir do britador de mandíbula

\begin{tabular}{|lc|ccc|}
\hline \multicolumn{2}{|c|}{ Britador mandíbulas } & \multicolumn{3}{c|}{ IPT N49 } \\
Fração & Num. part. & b/a & c/b & classificação \\
\hline$<25 ;>19$ & 66 & 0,75 & 0,68 & cúbica \\
$<19 ;<12$ & 87 & 0,74 & 0,68 & cúbica \\
$<12 ;>9$ & 57 & 0,73 & 0,68 & cúbica \\
\hline
\end{tabular}

Tabela 2.7 - Índices de forma e classificação dos agregados obtidos a partir do britador por impacto

\begin{tabular}{|lc|ccc|}
\hline \multicolumn{2}{|l|}{ Britador impactos } & \multicolumn{3}{|c|}{ IPT N49 } \\
Fração & Num. part. & b/a & c/b & classificação \\
\hline$<\mathbf{2 5} ;>\mathbf{1 9}$ & 82 & 0,76 & 0,71 & cúbica \\
$\mathbf{< 1 9 ;}>\mathbf{1 2}$ & 65 & 0,74 & 0,71 & cúbica \\
$<\mathbf{1 2} ;>\mathbf{9}$ & 57 & 0,74 & 0,66 & cúbica \\
\hline
\end{tabular}

Concluí-se, portanto, que não existem diferenças acentuadas no formato dos grãos obtidos a partir dos dois tipos de britadores estudados. 


\section{CARACTERIZAÇÃO DOS AGREGADOS RECICLADOS DESTINADOS À MOLDAGEM DOS CORPOS DE PROVA DE CONCRETO}

Devido à similaridade das propriedades apresentadas pelos agregados obtidos através do britador de mandíbula e do britador de impacto, e ao menor custo envolvido na utilização do primeiro devido ao menor desgaste do mesmo, optou-se pela utilização do britador de mandíbula para a obtenção do agregado destinado à confecção dos concretos. O material a ser britado para as moldagens foi dividido em duas partes iguais, uma delas foi britada em ciclo fechado até se obterem agregados com dimensão máxima $25 \mathrm{~mm}$ e a outra até se obterem agregados com dimensão máxima $38 \mathrm{~mm}$. A fração passante na peneira de abertura $4,8 \mathrm{~mm}$, nos dois casos, continuou a ser britada em ciclo fechado até que a dimensão máxima das partículas fosse inferior a 2,4 $\mathrm{mm}$, a fim de aproximar a curva granulométrica dos agregados miúdos naturais àquela dos agregados miúdos naturais a serem utilizados nos concretos.

\subsection{METODOLOGIA}

3.1.1 Curvas granulométricas, massa específica, absorção de água, porosidade aparente

Para caracterizar os agregados reciclados quanto às curvas granulométricas, massa específica aparente e real do agregado graúdo, absorção de água, e porosidade aparente dos agregados graúdos foram feitos os mesmos ensaios descritos no capítulo 2. Além destes, foram previstos outros ensaios descritos a seguir:

\section{Massa específica real e aparente dos agregados miúdos}

A determinação da massa específica real dos agregados miúdos foi feita com auxílio do picnômetro seguindo as instruções da norma DNER-ME 084 (1995). A partir do valor obtido por esse ensaio e do valor de absorção de água (obtido pelo ensaio da 
norma ABNT NBR NM 52 (2002), foi calculada a massa específica aparente do agregado a partir da eq.(15).

$$
M E A=\frac{M E R}{(A \cdot M E R+100)}
$$

onde:

A (\%): absorção de água dos agregados

$\operatorname{MER}\left(\mathrm{g} / \mathrm{cm}^{3}\right)$ : massa específica real

$\operatorname{MEA}\left(\mathrm{g} / \mathrm{cm}^{3}\right)$ : massa específica aparente

Também foi realizado o ensaio previsto na norma ABNT NBR 9776 (1987), que determina a massa específica aparente de agregados miúdos com auxílio do frasco Chapman. Os resultados obtidos dessas duas maneiras foram então confrontados.

\section{Ensaio de absorção proposto por Damineli (2007)}

O ensaio proposto por Damineli (2007) para determinação da absorção dos agregados foi realizado a fim de se confirmar os resultados obtidos pelo ensaio de absorção de agregados miúdos proposto na norma ABNT NBR NM 30 (2001), DNER-ME 084 (1995) e ABNT NBR 9776 (1987). Apesar de o método ter sido criado para agregados graúdos, ensaios feitos no LCT têm revelado que esse ensaio também é válido para o caso dos agregados miúdos.

A breve descrição do ensaio, conforme apresenta o autor, é apresentada a seguir:

1) saturação da amostra com aplicação de depressão de vácuo por 30 minutos; 2) préaquecimento em microondas da amostra imersa em água, antes do início da coleta dos dados de secagem, até estabilização da temperatura, por tempo aproximado de 45 minutos; 3) secagem em microondas, com medições periódicas da massa do conjunto água/agregado (Figura 3.1).

Com as medidas obtidas confecciona-se o gráfico tempo versus taxa de secagem eq.(16) - de onde é obtido o instante em que a massa seca ocorre ao se extrapolar o segundo período de taxa decrescente linear (Figura 3.2). 
TaxaSecagem $(t)($ massa $/$ tempo $)=\frac{\left\lfloor M_{\text {conj.agreg / água }(t-1)}\right\rfloor-\left\lfloor M_{\text {conj.agreg / água }(t)}\right\rfloor}{(t)-(t-1)}$

onde:

$\mathrm{M}_{\text {conj.agreg/água(t) }}(\mathrm{g})$ : massa total formada pelo agregado mais a umidade total contida no recipiente no instante $t$;

$\mathrm{M}_{\text {seca }}(\mathrm{g})$ : massa da amostra seca em estufa.

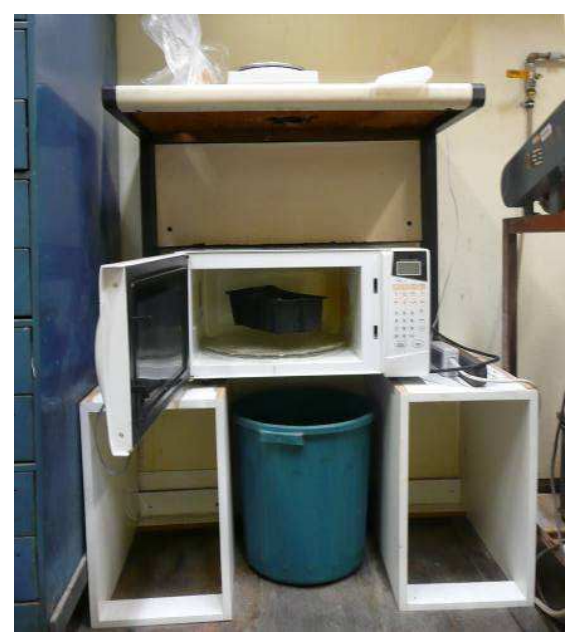

Figura 3.1 - Montagem dos equipamentos para o ensaio proposto por Damineli (2007)

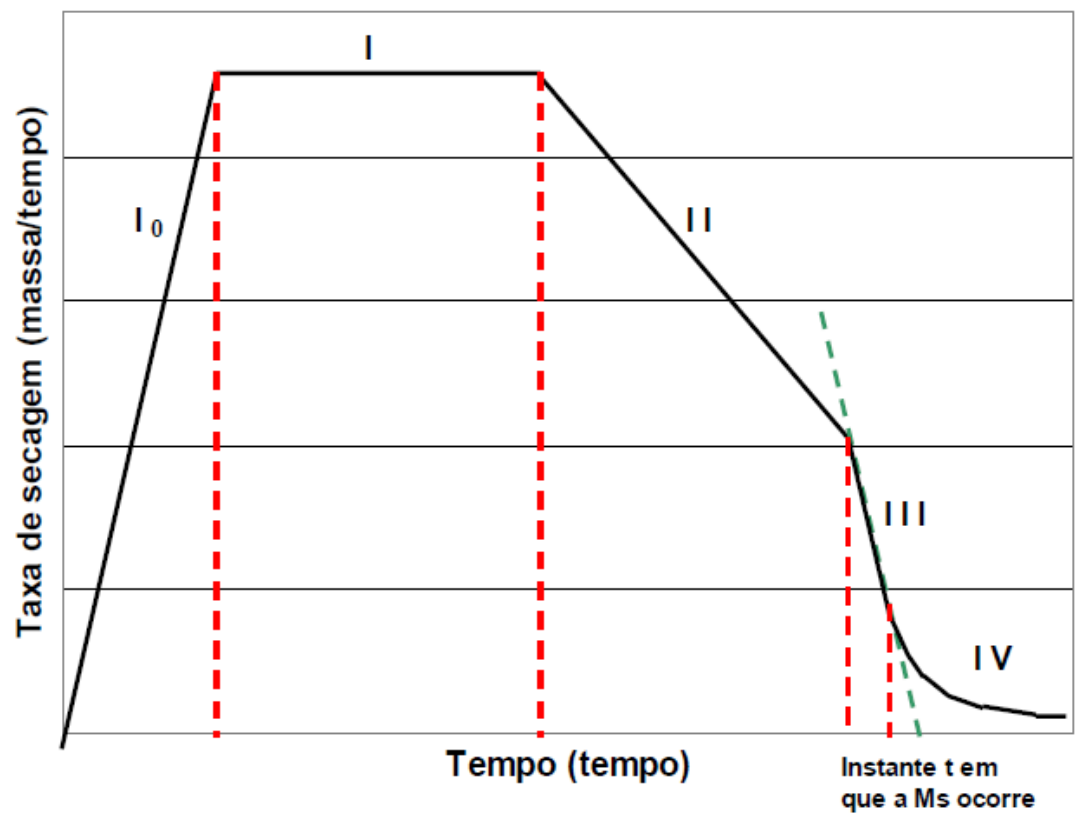

Figura 3.2 - Esquema dos períodos de secagem obtidos através dos dados de secagem em microondas (linhas vermelhas) e do método de determinação da $M_{S}$ (linha verde)

(DAMINELI, 2007) 
Calcula-se o teor de umidade para cada instante a partir da eq.(17) e confeccionase o gráfico teor de umidade versus taxa de secagem (Figura 3.3) determinando-se os diferentes períodos de secagem e o teor de umidade no instante em que a secagem passa a ocorrer dentro dos poros do material $(A)$.

$$
\operatorname{TeorUmidade}(t)(\%)=\frac{M_{\text {conj.agreg } / \text { água }(t)}-M_{\text {seca }}}{M_{\text {seca }}} \times 100
$$

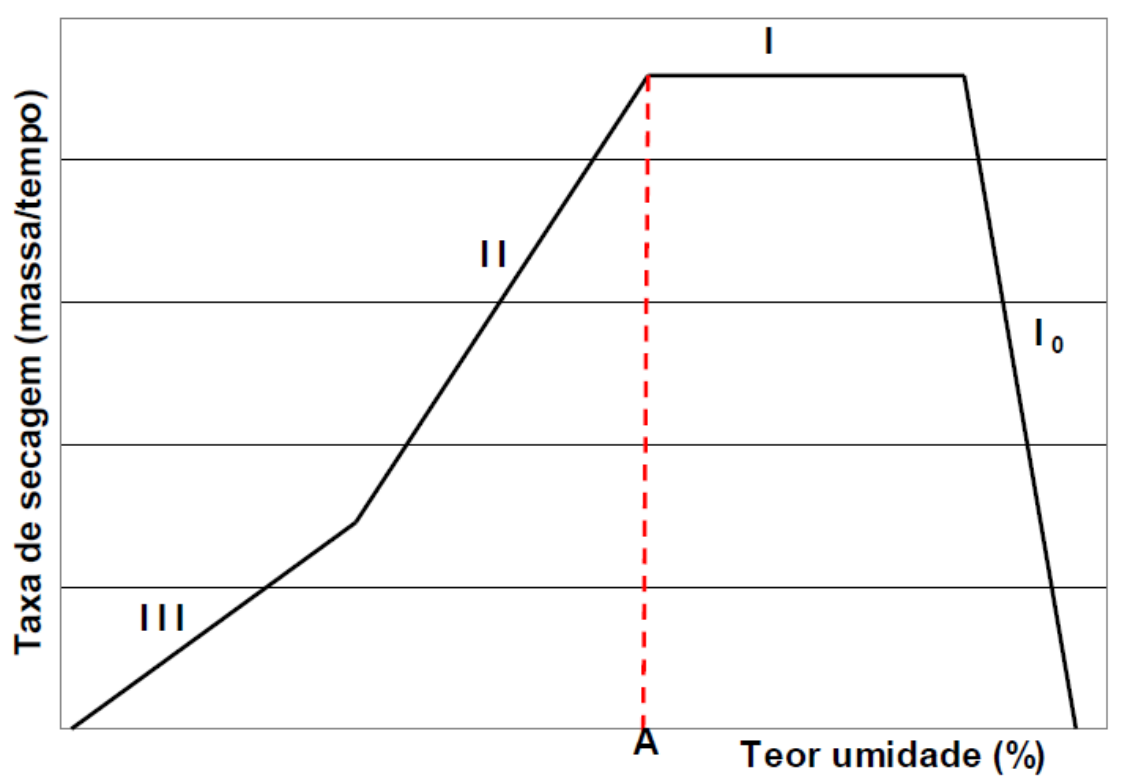

Figura 3.3 - Esquema da determinação da absorção (A) no ponto de intersecção entre fases de secagem I e II (DAMINELI, 2007)

O cálculo da absorção de água (A), da massa específica real (MER) e da massa específica aparente (MEA) é feito segundo as equações:

$$
\begin{array}{r}
A(\%)=\frac{\left(M_{S S S}-M_{\sec a}\right)}{M_{\sec a}} \times 100 \\
M E R=\frac{M_{\sec a}}{\left(M_{\sec a}-M_{\text {sub }}\right)} \\
M E A=\frac{M_{\text {sec } a}}{\left(M_{S S S}-M_{\text {sub }}\right)}
\end{array}
$$

onde:

A (\%): absorção de água 
$M_{\text {Sss }}$ (g): massa da amostra na condição saturado e de superfície seca $\mathrm{M}_{\text {sub }}(\mathrm{g})$ : massa da amostra submersa em água

\subsubsection{Apreciação petrográfica dos agregados}

A fim de caracterizar os agregados quanto sua composição mineralógica, foi realizada a apreciação petrográfica do material segundo a norma ABNT NBR 7389 (1982), verificando se tratar de um agregado composto de quartzo, feldspato e biotita, cuja rocha se apresenta sã (os minerais conservam suas características de cor e brilho sem sinais de alteração) - Anexo $\mathrm{A}$.

\subsubsection{Teor de aglomerantes}

Para estimar o teor de aglomerantes no agregado foi utilizado o método proposto por Quarcioni (1998), que se baseia no ataque em solução de ácido clorídrico. Este método é válido somente quando o agregado natural utilizado não possui fração solúvel em ácido, pois considera que toda a fração solúvel é proveniente dos aglomerantes e a fração insolúvel proveniente dos agregados naturais. No caso do agregado natural utilizado nas placas do Rodoanel Metropolitano Mário Covas, pode-se observar que a rocha utilizada não apresenta fração solúvel no ácido, podendo ser utilizado esse método.

O ensaio foi realizado (comercialmente) no Laboratório de Materiais de Construção Civil do Instituto de Pesquisas Tecnológicas do Estado de São Paulo (IPT) para duas amostras: a primeira corresponde aos agregados graúdos com dimensão máxima de $25 \mathrm{~mm}$ e a segunda aos agregados miúdos (com dimensão máxima de $2,4 \mathrm{~mm}$ ) gerados na obtenção dos primeiros. Ambas as amostras foram britadas $\mathrm{e}$ moídas até atingir diâmetro máximo de 0,84 $\mathrm{mm}$ antes de sofrer 0 ataque ácido. As etapas do ensaio são:

1 - adição de 5,0 g de amostra seca $\left(\mathrm{m}_{\mathrm{A}}\right)$ em um béquer de $500 \mathrm{ml}$;

2 - adição de $50 \mathrm{ml}$ de solução de ácido clorídrico $\mathrm{HCL} 33 \%$ (1HCl : 2 água, em volume); 
3 - agitação por aproximadamente 10 minutos com o auxílio de bastão de vidro mantendo o béquer em banho-maria por alguns minutos;

4 - filtragem em papel 40 (filtração média), previamente tarado $\left(m_{1}\right)$ lavando-se o resíduo, sequencialmente, com:

a) três porções de $20 \mathrm{ml}$ de solução de $\mathrm{Na}_{2} \mathrm{CO}_{3} 5 \%$,

b) solução de $\mathrm{HCl}$ 5\% para eliminação do excesso de carbonato,

c) água deionizada até eliminação de cloretos confirmada por teste qualitativo com solução de nitrato de prata $(0,1 \%)$;

5 - secagem do resíduo da filtragem e o papel filtro a $105^{\circ} \mathrm{C}$ por uma hora;

6 - resfriamento em dessecador e pesagem $\left(m_{2}\right)$;

7 - cálculo do RI segundo a equação:

$$
R I=\frac{\left(m_{2}-m_{1}\right) \times 100}{m_{A}}
$$

O teor de aglomerantes pode ser determinado a partir da seguinte equação (ANGULO, 2005):

$$
A(\%)=1-R I(\%)
$$

onde:

A (\%): teor estimado de aglomerantes

$\mathrm{RI}(\%)$ : resíduo insolúvel do ataque por solução de $\mathrm{HCl}$ seco a $100^{\circ} \mathrm{C}$ em relação à massa da alíquota inicial 


\subsection{APRESENTAÇÃO E DISCUSSÃO DOS RESULTADOS}

\subsubsection{Curvas granulométricas}

As curvas granulométricas dos agregados obtidas são apresentadas nas Figuras 3.4 a 3.6.

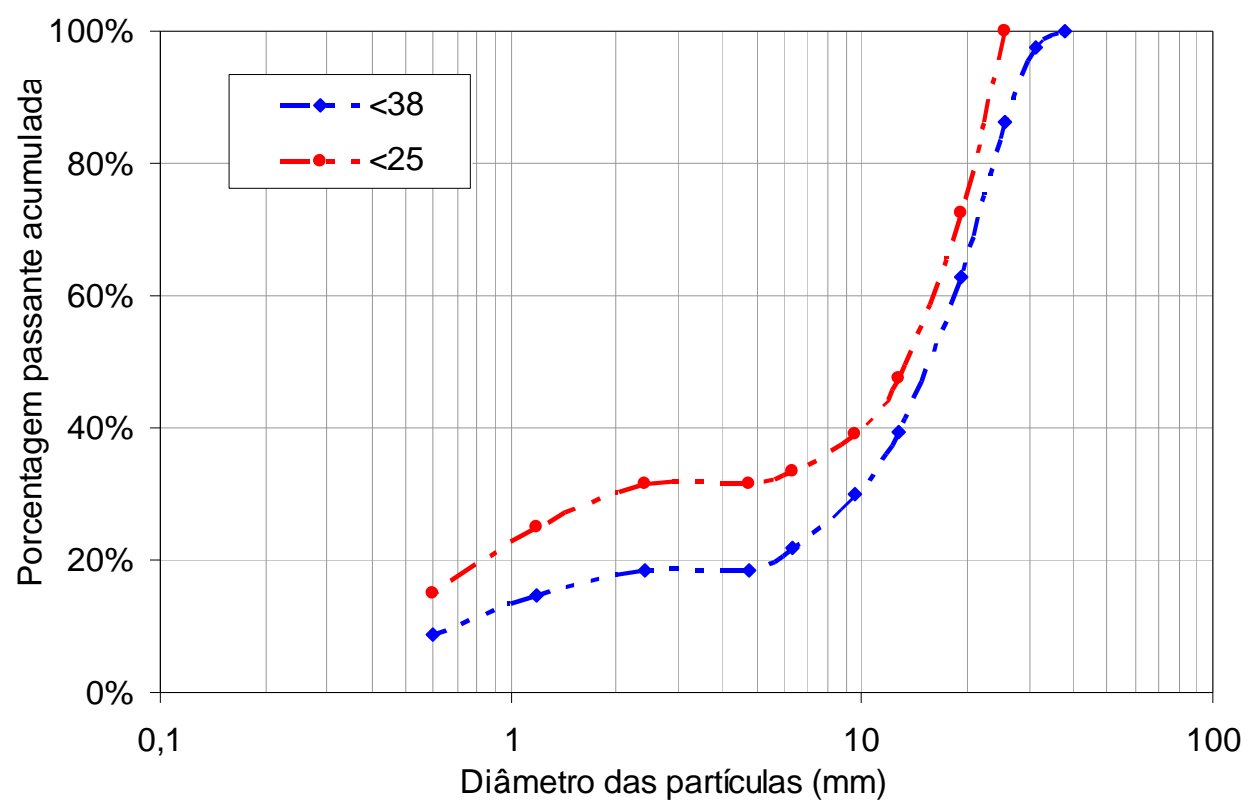

Figura 3.4 - Curvas granulométricas dos agregados utilizados no concreto estudado

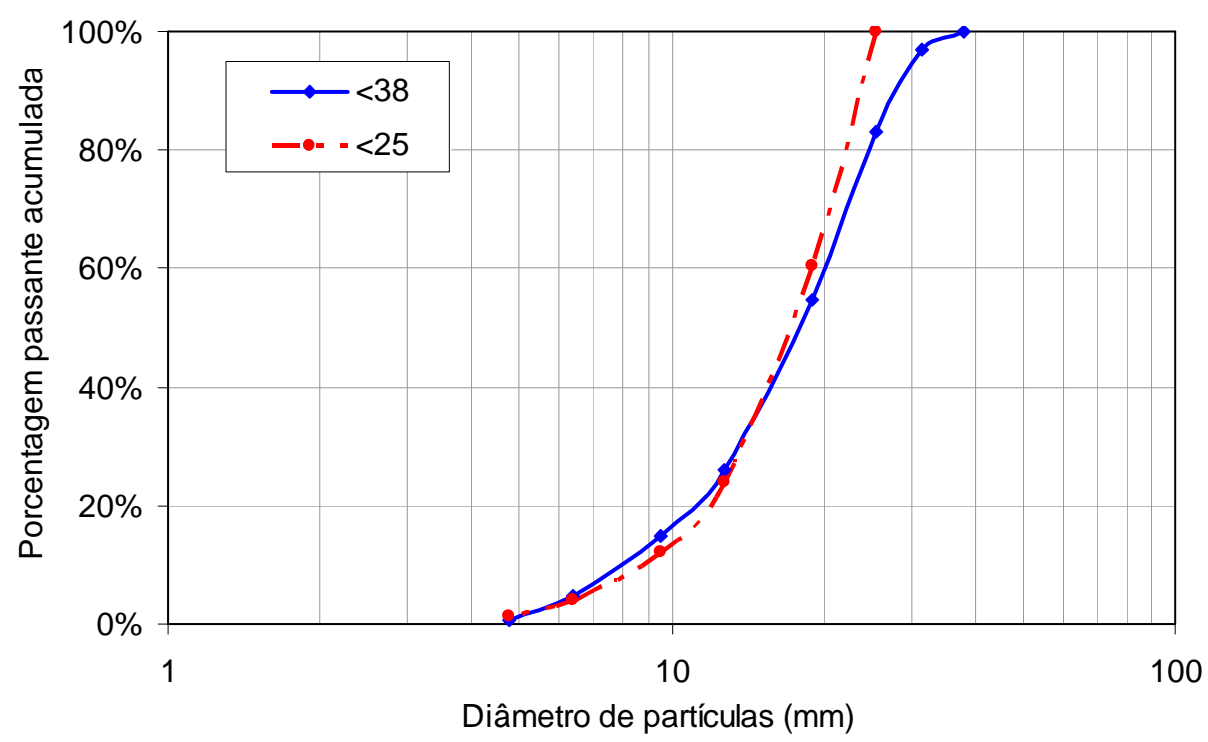

Figura 3.5 - Curvas granulométricas dos agregados graúdos utilizados no concreto estudado 


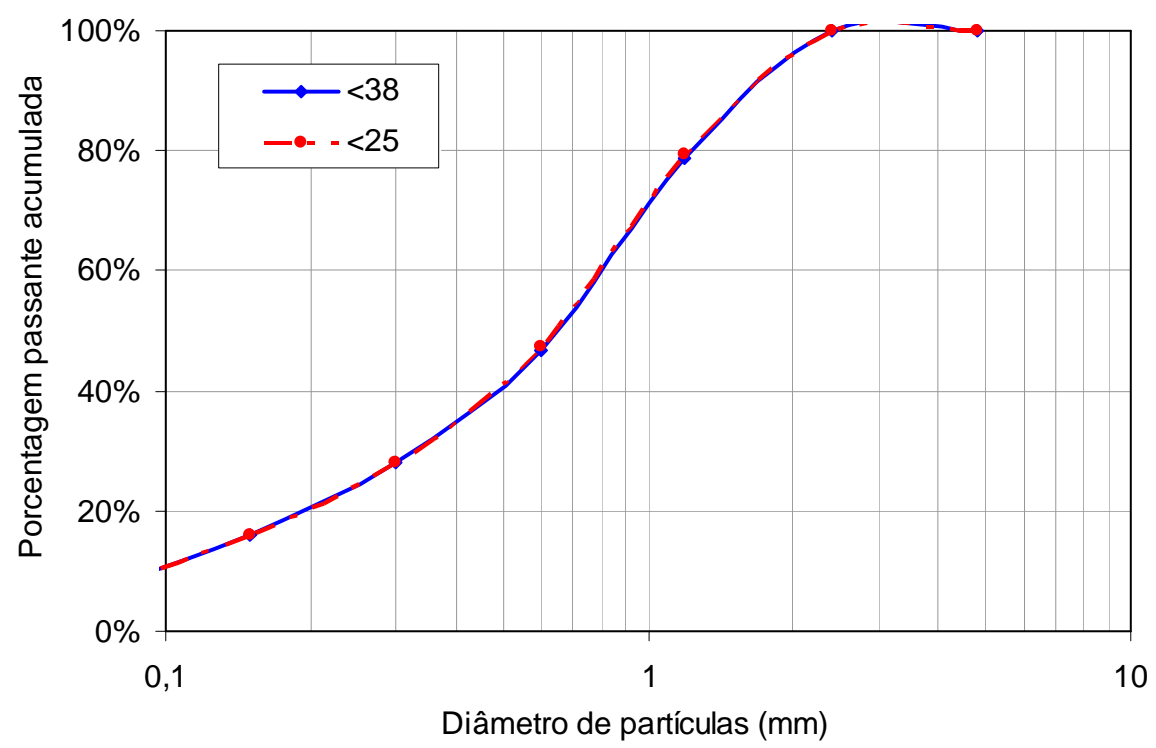

Figura 3.6 - Curvas granulométricas dos agregados miúdos utilizados no concreto estudado

A curva granulométrica correspondente aos agregados graúdos é muito semelhante nos dois casos. A quantidade de agregados com dimensão maior que $25 \mathrm{~mm}$ nos agregados com dimensão máxima de $38 \mathrm{~mm}$ é de aproximadamente 13,8\% em massa, sendo apenas $2,4 \%$ retido na peneira de abertura $31,5 \mathrm{~mm}$.

Apesar das curva granulométricas dos agregados miúdos produzidos serem muito semelhantes, a quantidade de agregados miúdos produzida é significativamente maior no caso da britagem em circuito fechado até obtenção de agregados com dimensão máxima $25 \mathrm{~mm}$, aproximadamente $31,5 \%$, enquanto que no caso dos agregados com dimensão máxima $38 \mathrm{~mm}$ foram gerados somente $18,5 \%$ de agregados miúdos (em massa).

Essa tendência é observada porque ao se cominuir o material a fim de se obter um maior número de partículas de dimensões menores uma maior quantidade de material aderido à superfície dos agregados se solta, gerando, portanto, maior quantidade de agregados miúdos. 
3.2.2 Massa específica, absorção de água, porosidade e teor de aglomerantes

$\mathrm{Na}$ Tabela 3.1 estão resumidos os resultados obtidos para os ensaios de determinação da massa específica real e aparente, da absorção de água, da porosidade aparente dos agregados graúdos e da estimativa do teor de aglomerantes.

Tabela 3.1 - Resultados dos ensaios de determinação da massa específica real e aparente, absorção de água, porosidade e estimativa do teor de aglomerantes

\begin{tabular}{lcccc}
\hline & \multicolumn{2}{c}{ graúdos } & \multicolumn{2}{c}{ miúdos } \\
& $<25 \mathrm{~mm}$ & $<38 \mathrm{~mm}$ & $<25 \mathrm{~mm}$ & $<38 \mathrm{~mm}$ \\
\hline massa específica aparente (NBR NM 53) & 2,32 & 2,33 & & \\
\hline massa específica aparente (NBR 9776) & - & - & 2,47 & 2,46 \\
\hline $\begin{array}{l}\text { massa específica aparente (a partir dos resultados } \\
\text { obtidos nos ensaios previstos pelas normas NBR }\end{array}$ & - & - & \multirow{2}{*}{2,27} & 2,25 \\
NM 53/2003 e DNER-ME 084) & - & & & \\
\hline massa específica real (DNER-ME 084) & - & - & 2,70 & 2,65 \\
\hline $\begin{array}{l}\text { massa específica real (ensaio proposto por } \\
\text { DAMINELI, 2007) - Anexo C }\end{array}$ & - & - & 2,50 & 2,46 \\
\hline $\begin{array}{l}\text { massa específica aparente (método proposto por } \\
\text { DAMINELI, 2007) - Anexo C }\end{array}$ & - & - & 2,15 & 2,17 \\
\hline $\begin{array}{l}\text { absorção de água (método proposto por } \\
\text { DAMINELI, 2007) - Anexo C }\end{array}$ & - & - & $6,58 \%$ & $5,31 \%$ \\
\hline absorção de água (NBR NM 53 e NBR NM 30) & $5,39 \%$ & $5,00 \%$ & $6,95 \%$ & $6,71 \%$ \\
\hline porosidade aparente (NBR NM 53) & $12,51 \%$ & $11,70 \%$ & - & - \\
\hline $\begin{array}{l}\text { teor de aglomerantes (método proposto por } \\
\text { QUARCIONI, 1998) - Anexo B }\end{array}$ & $29,0 \%$ & - & $22,3 \%$ & - \\
\hline
\end{tabular}

Os valores de absorção de água dos agregados graúdos encontrados indicam que os agregados com dimensão máxima $25 \mathrm{~mm}$ possuem maior quantidade de pasta aderida em sua composição quando comparados àqueles com dimensão máxima $38 \mathrm{~mm}$. Os valores de porosidade aparente encontrados confirmam essa tendência, já que a porosidade é maior para os agregados de dimensão máxima $25 \mathrm{~mm}$. Nos agregados miúdos o comportamento é inverso, possuindo maior absorção os agregados miúdos gerados na produção do agregado graúdo de diâmetro máximo $38 \mathrm{~mm}$. Os valores de absorção obtidos pelo ensaio proposto por Damineli (2007) para os agregados miúdos confirmam essa tendência, apesar dos valores não serem os mesmos daqueles obtidos pelo ensaio proposto pela ABNT NBR NM 30 
(2001) (haja vista as dificuldades em se determinar o ponto de saturação com superfície seca do agregado miúdo).

Os maiores valores de absorção de água dos agregados miúdos e o resultado do ensaio de estimativa do teor de aglomerante indicam que os agregados miúdos gerados possuem maior quantidade de pasta de cimento aderida se comparados aos agregados graúdos, confirmando os resultados da análise química feita no estudo comparativo entre métodos de britagem e o comportamento previsto a partir da literatura revisada.

Os resultados do ensaio de determinação de massa específica aparente pelo frasco de Chapman - ABNT NBR 9776 (1987) - são superiores aos resultados encontrados pelo ensaio proposto por Damineli (2007) e pelo cálculo feito a partir dos ensaios propostos pelas normas ABNT NBR NM 53 (2003) e DNER-ME 084 (1995); além disso, são superiores aos valores encontrados para os agregados graúdos, o que não deveria acontecer, pois como visto anteriormente, os agregados miúdos apresentam maior absorção e, portanto, maior porosidade. A provável explicação para tal fato é a de que o ensaio previsto pela ABNT NBR 9776 (1987) foi elaborado para agregados compostos por areia de quartzo, ou seja, não prevê agregados com alta porosidade como é o caso dos agregados reciclados. Ao se realizar o ensaio, a água penetra rapidamente nos poros do agregado reciclado, que dessa maneira deixam de ser contabilizados acarretando em valores altos de massa específica aparente. $O$ valor de massa específica determinado por esse ensaio fica, portanto, acima do valor de massa específica aparente e abaixo do valor de massa específica real. 


\section{CONCRETOS CONTENDO AGREGADOS RECICLADOS}

\subsection{METODOLOGIA}

\subsubsection{Materiais utilizados}

\section{Agregados}

Os agregados reciclados utilizados foram descritos no Capítulo 3. Os agregados naturais utilizados para a confecção do concreto de controle foi coletado na pedreira Embu, pertencente à Embu SA Engenharia e Comércio. Foram coletados os produtos indicados na Tabela 4.1.

Tabela 4.1 - Material fornecido pela pedreira Embu

\begin{tabular}{|l|l|}
\hline \multicolumn{1}{|c|}{ Produto } & \multicolumn{1}{c|}{ Malha de corte } \\
\hline Pedra 2 & $>21,0 \mathrm{~mm}<28,0 \mathrm{~mm}$ \\
\hline Pedra 1 & $>12,7 \mathrm{~mm}<21,0 \mathrm{~mm}$ \\
\hline Pedra meia & $>11,0 \mathrm{~mm}<12,7 \mathrm{~mm}$ \\
\hline Pedrisco & $>5,5 \mathrm{~mm}<9,5 \mathrm{~mm}$ \\
\hline
\end{tabular}

Todo o material foi lavado e peneirado no laboratório, de forma a eliminar as partículas finas e separar o material segundo as frações: $>12,5 \mathrm{~mm}<19 \mathrm{~mm}$; $>9,5 \mathrm{~mm}<12,5 \mathrm{~mm} ;>6,3 \mathrm{~mm}<9,5 \mathrm{~mm} ;>4,8 \mathrm{~mm}<6,3 \mathrm{~mm}$, e $<4,8 \mathrm{~mm}$. Para as moldagens foi utilizada cada uma dessas frações segundo a mesma proporção em que apareciam no agregado reciclado, isto é, compondo a curva granulométrica dos agregados naturais de forma reproduzir aquela dos agregados reciclados. Esse procedimento foi realizado a fim de eliminar a influência da granulometria do agregado graúdo nas propriedades dos concretos estudados.

Os agregados miúdos naturais utilizados foram disponibilizados pela Holcim, sendo compostos de $25 \%$ de areia de quartzo e $75 \%$ de areia artificial. A areia de quartzo foi fornecida pela Concresand, possuindo as características apresentadas na Tabela 4.2 . 
Tabela 4.2 - Caracterização da areia de quartzo (Tabela cedida pela Holcim)

\begin{tabular}{||l|rl||}
\hline MÓDULO DE FINURA (NBR 7217) & \multicolumn{1}{|c||}{1,262} \\
\hline DIMENSÃO MÁXIMA (NBR 7217) & $0,6 \mathrm{~mm}$ \\
\hline MASSA ESPECÍFICA (NBR 9776) & $2,620 \mathrm{~kg} / \mathrm{dm}^{3}$ \\
\hline MASSA UNITÁRIA SÊCA (NBR 7251) & $1,430 \mathrm{~kg} / \mathrm{dm}^{3}$ \\
\hline MATERIAL PULVERULENTO (NBR 7211) & $1,71 \%$ \\
\hline
\end{tabular}

A areia artificial (proveniente da britagem de rochas) foi fornecida pela Embu, e possui as características apresentadas na Tabela 4.3.

Tabela 4.3 - Caracterização da areia fornecida pela pedreira Embu (Tabela cedida pela Holcim)

\begin{tabular}{||l|rl||}
\hline MÓDULO DE FINURA (NBR 7217) & 2,639 \\
\hline DIMENSÃO MÁXIMA (NBR 7217) & $4,8 \mathrm{~mm}$ \\
\hline MASSA ESPECÍFICA (NBR 9776) & $2,655 \mathrm{~kg} / \mathrm{dm}^{3}$ \\
\hline MASSA UNITÁRIA SÊCA (NBR 7251) & $1,610 \mathrm{~kg} / \mathrm{dm}^{3}$ \\
\hline MATERIAL PULVERULENTO (NBR 7211) & $16,88 \quad \%$ \\
\hline
\end{tabular}

As curvas granulométricas dos agregados miúdos convencionais utilizados são apresentadas na Figura 4.1.

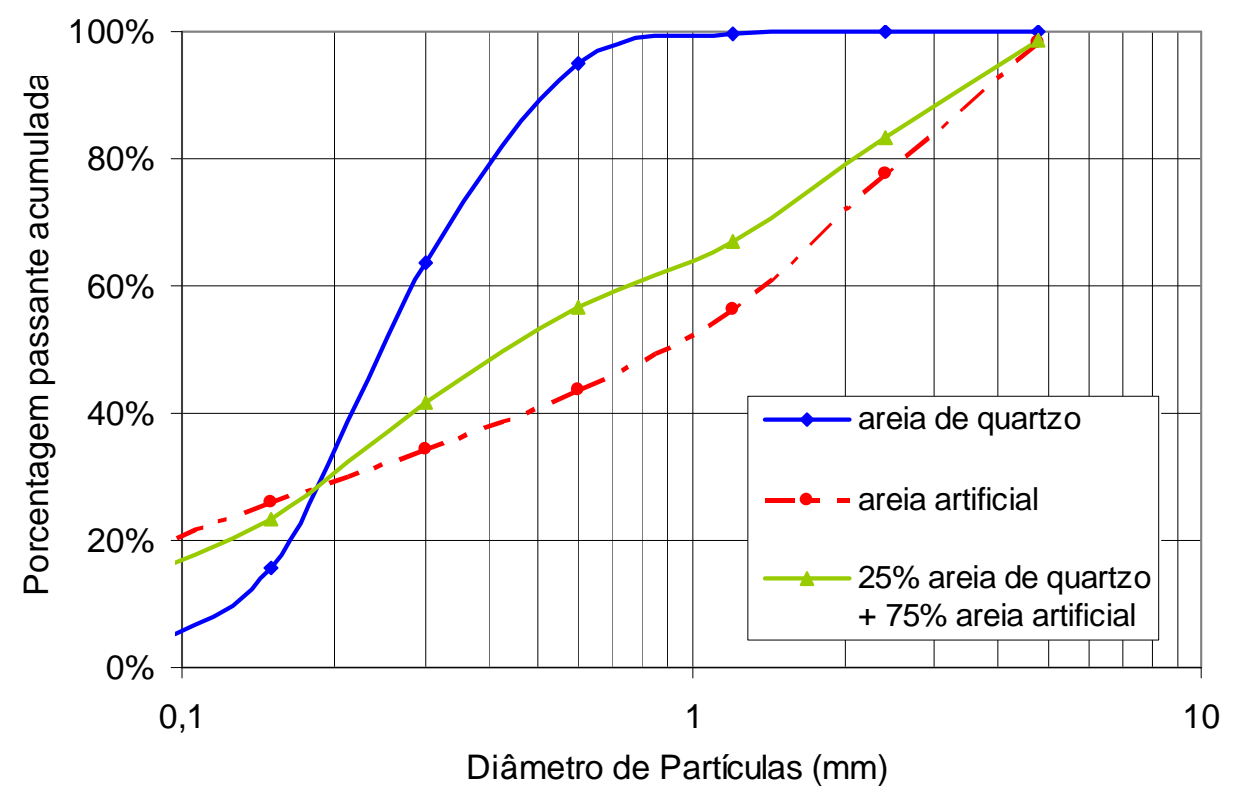

Figura 4.1 - Curva granulométrica dos agregados miúdos convencionais 


\section{Cimento}

O cimento utilizado foi o CP III 40 RS produzido pela Holcim e proveniente de Barroso, Minas Gerais. Trata-se de um ligante hidráulico produzido através da moagem de clínquer Portland e escória granulada de alto forno. Atende às normas brasileiras ABNT NBR 5735 (1991) e NBR 5737 (1992). Na Tabela 4.4 são apresentadas as características do cimento:

Tabela 4.4 - Caracterização do cimento (tabela cedida pela Holcim)

\begin{tabular}{|c|c|c|}
\hline Parâmetro & Und. & CP III - 40 RS \\
\hline$\# 325$ & $\%$ & 1,9 \\
\hline$\# 400$ & $\%$ & 4,6 \\
\hline Superfície específica - Blaine (NBR 7224/84) & $\mathrm{cm}^{2} / \mathrm{g}$ & 4.141 \\
\hline A/C - pasta de consistência normal (NBR 11580/91c) & $\%$ & 31,2 \\
\hline Tempo de pega (NBR 11581/91d) & $\mathrm{min}$ & $195-257$ \\
\hline Resistência à compressão (NBR 7215/97) & & $9,8(1 \mathrm{dia})$ \\
& & $26,0(3 \mathrm{dias})$ \\
& & $58,9(7 \mathrm{dias})$ \\
\hline Perda ao Fogo - $1.000{ }^{\circ}$ (NBR 5743/04a) & $\%$ & 2,48 \\
\hline Resíduo Insolúvel (NBR 5744/04b) & $\%$ & 0,98 \\
\hline
\end{tabular}

\section{Plastificante}

O plastificante utilizado foi o Muraplast FK 100 B, da MC-Bauchemie Brasil, disponível na central de concreto da Holcim onde os corpos de prova foram moldados. Trata-se de um plastificante multifuncional, a base de lignossulfonatos, de pega normal que age reduzindo a tensão superficial da água de mistura e, consequentemente, melhorando a dispersão das partículas de cimento e a trabalhabilidade. O plastificante é comercializado em estado líquido e possui massa específica de $1,20 \mathrm{~g} / \mathrm{cm}^{3}$, sendo sua dosagem recomendada de $0,2 \%$ a $1,0 \%$ sobre o peso do cimento. 


\subsubsection{Concretos estudados}

Foram estudados 7 concretos, todos com o mesmo traço em volume. O primeiro concreto de controle (C1) - foi produzido somente com agregados convencionais (naturais e artificiais). Os concretos com emprego de agregados reciclados tiveram em seu proporcionamento $100 \%$ do agregado graúdo reciclado. Os agregados miúdos (areia grossa a fina) foram substituídos pelos miúdos gerados a partir da britagem do concreto original nas proporções: $100 \%$ agregado miúdo convencional, $75 \%$ agregado miúdo convencional mais $25 \%$ agregado miúdo reciclado, e $50 \%$ agregado miúdo convencional mais $50 \%$ agregado miúdo reciclado. Todos os concretos contendo agregados graúdos reciclados foram confeccionados, nas mesmas proporções em volume, para o caso de agregados com dimensão máxima $25 \mathrm{~mm}$ e $38 \mathrm{~mm}$. Na Tabela 4.5 são apresentados os 7 concretos que foram confeccionados para o estudo.

Tabela 4.5 - Concretos estudados

\begin{tabular}{|l|c|c|c|}
\hline $\begin{array}{c}\text { Concreto } \\
\text { estudado }\end{array}$ & Agregado graúdo & Agregado miúdo & $\begin{array}{c}\text { Máximo } \\
\text { diâmetro do } \\
\text { agregado } \\
\text { graúdo } \\
\text { (mm) }\end{array}$ \\
\hline Convencional & convencional $(100 \%)$ & convencional $(100 \%)$ & 25 \\
\hline $4 / 25-\mathrm{F} 1$ & reciclado $(100 \%)$ & convencional $(100 \%)$ & 25 \\
\hline $4 / 25-\mathrm{F} 2$ & reciclado $(100 \%)$ & convencional $(75 \%)+$ reciclado $(25 \%)$ & 25 \\
\hline $4 / 25-\mathrm{F} 3$ & reciclado $(100 \%)$ & convencional $(50 \%)+$ reciclado $(50 \%)$ & 25 \\
\hline $4 / 38-\mathrm{F} 1$ & reciclado $(100 \%)$ & convencional $(100 \%)$ & 38 \\
\hline $4 / 38-\mathrm{F} 2$ & reciclado $(100 \%)$ & convencional $(75 \%)+$ reciclado $(25 \%)$ & 38 \\
\hline $4 / 38-\mathrm{F} 3$ & reciclado $(100 \%)$ & convencional $(50 \%)+$ reciclado $(50 \%)$ & 38 \\
\hline
\end{tabular}

\subsubsection{Procedimentos de dosagem}

A dosagem do concreto foi realizada somente para o concreto convencional de forma empírica, buscando-se um concreto de resistência à tração na flexão média de no mínimo $5 \mathrm{MPa}$, abatimento de $55 \pm 10 \mathrm{~mm}$ e relação a/c de no máximo 0,50 .

O método de dosagem utilizado foi o método IPT/EPUSP definido por Helene e Terzian (1992). O procedimento pode ser resumido pelas seguintes etapas: 
1. obtenção do teor de argamassa para o traço 1:5,0 (fixado o teor de plastificante para $0,4 \%$ da quantidade de cimento em peso);

2. com o teor de argamassa encontrado e abatimento fixado em $55 \pm 10 \mathrm{~mm}$, moldagem de CP's prismáticos (100×100x400mm) com os traços 1:3,5; 1:5,0 e 1:6,5 (variação do consumo de cimento para obtenção de um traço rico, um médio e um pobre);

3. ensaio de tração na flexão aos 28 dias obtendo-se o diagrama de dosagem;

4. determinação do traço que proporciona resistência de dosagem de no mínimo $5 \mathrm{MPa}$ com máxima relação a/c de $0,5^{9}$.

Para determinação do teor de argamassa ideal para o traço 1:5,0 (cimento: agregados secos totais, em massa) partiu-se de um concreto com teor de argamassa de $41 \%$ e foi sendo acrescentado paulatinamente material necessário para ir aumentando em $2 \%$ o teor de argamassa até se chegar, visualmente, a um concreto coeso e sem vazios na superfície exposta. O teor de água foi sendo ajustado, juntamente com o teor de argamassa, para se obter um concreto com abatimento de $55 \pm 10 \mathrm{~mm}$. Na Tabela 4.6 são apresentadas as etapas realizadas para a obtenção do teor de argamassa ideal. Devido ao longo tempo decorrido desde o início da mistura até se chegar ao teor de argamassa de $49 \%$, adotou-se que o teor de $48 \%$ seria suficiente.

\footnotetext{
${ }^{9}$ Encontram-se na literatura limites máximos de relação a/c para concretos utilizados em pavimentos de concreto entre 0,45 (TECHNISCHE FORSCHUNG UND BERATUNG FUR ZEMENT UND BETON, 2000) e 0,55 (BALBO, 2009). Para esse trabalho foi adotada a média desses valores.
} 
Tabela 4.6 - Determinação do teor ideal de argamassa para o traço 1,0:5,0

\begin{tabular}{|c|c|c|c|c|c|c|c|c|c|c|c|c|c|c|}
\hline \multirow{2}{*}{$\begin{array}{c}\text { Teor de } \\
\text { argamassa } \\
(\%)\end{array}$} & \multirow{2}{*}{$\begin{array}{c}\text { traço } \\
\text { unitário } \\
(1: a: p)\end{array}$} & \multicolumn{6}{|c|}{ Quantidade de areia $(\mathrm{kg})$} & \multicolumn{2}{|c|}{$\begin{array}{l}\text { Quantidade de } \\
\text { cimento }(\mathrm{kg})\end{array}$} & \multicolumn{2}{|c|}{$\begin{array}{l}\text { Quantidade de } \\
\text { plastificante (g) }\end{array}$} & \multicolumn{2}{|c|}{$\begin{array}{l}\text { Quantidade de } \\
\text { água }(\mathrm{kg})\end{array}$} & \multirow{2}{*}{$\begin{array}{l}\text { Relação } \\
\text { a/c final }\end{array}$} \\
\hline & & $\begin{array}{c}\text { Massa } \\
\text { total }\end{array}$ & $\begin{array}{l}\text { Acréscimo } \\
\text { na Mistura }\end{array}$ & $\begin{array}{c}\text { Massa } \\
\text { areia de } \\
\text { quartzo }\end{array}$ & $\begin{array}{c}\text { Acréscimo } \\
\text { areia de } \\
\text { quartzo }\end{array}$ & $\begin{array}{c}\text { Massa } \\
\text { areia } \\
\text { artificial }\end{array}$ & $\begin{array}{l}\text { Acréscimo } \\
\text { areia } \\
\text { artificial }\end{array}$ & $\begin{array}{l}\text { Massa } \\
\text { total }\end{array}$ & $\begin{array}{l}\text { Acréscimo } \\
\text { na Mistura }\end{array}$ & $\begin{array}{c}\text { Massa } \\
\text { total }\end{array}$ & $\begin{array}{l}\text { Acréscimo } \\
\text { na Mistura }\end{array}$ & $\begin{array}{c}\text { Massa } \\
\text { total }\end{array}$ & $\begin{array}{l}\text { Acréscimo } \\
\text { na Mistura }\end{array}$ & \\
\hline \multirow[t]{2}{*}{41} & $1: 1,46: 3,54$ & 12,36 & & 3,09 & & 9,27 & & 8,47 & & 33,88 & & 4,24 & & 0,50 \\
\hline & & & 4,81 & & 1,20 & & 3,61 & & 0,96 & & 3,84 & & 0,48 & \\
\hline \multirow[t]{2}{*}{47} & $1: 1,82: 3,18$ & 17,17 & & 4,29 & & 12,88 & & 9,43 & & 37,72 & & 4,72 & & 0,50 \\
\hline & & & 1,85 & & 0,46 & & 1,39 & & 0,37 & & 1,48 & & 0,19 & \\
\hline 49 & $1: 1,94: 3,06$ & 19,02 & & 4,76 & & 14,27 & & 9,80 & & 39,20 & & 4,90 & & 0,50 \\
\hline 48 & $1: 1,88: 3,12$ & 17,35 & & 4,34 & & 13,01 & & 9,61 & & 38,448 & & 4,806 & & 0,50 \\
\hline
\end{tabular}

Características do Concreto

\begin{tabular}{|c|c|}
\hline \multicolumn{2}{|c|}{ Características do Concreto } \\
\hline 1. Teor de argamassa adotado $(\%)$ & 48 \\
\hline 2. Massa específica do concreto fresco $\left(\mathrm{kg} / \mathrm{m}^{3}\right)$ & 2399 \\
\hline 3. Teor de ar incorporado e/ou aprisionado $\left(\mathrm{L} / \mathrm{m}^{3}\right)$ & 1,4 \\
\hline 4. Abatimento obtido $(\mathrm{mm})$ & 50 \\
\hline
\end{tabular}

\begin{tabular}{|ccc|}
\hline \multicolumn{3}{|c|}{ Consumo por $\mathrm{m}^{3}$ de Concreto } \\
\hline 1. Cimento: & 369 & $\mathrm{~kg}$ \\
\hline 2. Água: & 185 & $\mathrm{~L}$ \\
\hline
\end{tabular}


Decidido o teor de argamassa ideal, partiu-se para a determinação do traço desejado. A Tabela 4.7 apresenta os traços adotados para a obtenção da curva de dosagem:

Tabela 4.7 - Traços definidos para etapa de dosagem

\begin{tabular}{|c|c|c|c|c|}
\hline Traço em massa & $1: \mathrm{m}$ & $1: 3,5$ & $1: 5,0^{10}$ & $1: 6,5$ \\
\hline & 1:a:p & $1: 1,16: 2,34$ & $1: 1,80: 3,12$ & $1: 2,60: 3,90$ \\
\hline Teor de argamassa & $\%$ & 48 & 47 & 48 \\
\hline $\begin{array}{l}\text { Agregado Graúdo } \\
\text { convencional }\end{array}$ & $\mathrm{kg}$ & 28,91 & 30,00 & 28,91 \\
\hline Agregado Miúdo Total & $\mathrm{kg}$ & 14,33 & 17,35 & 19,27 \\
\hline Areia de quartzo & $\mathrm{kg}$ & 3,58 & 4,34 & 4,82 \\
\hline Areia industrial & $\mathrm{kg}$ & 10,75 & 13,01 & 14,45 \\
\hline Cimento & $\mathrm{kg}$ & 12,35 & 9,61 & 7,41 \\
\hline Água & $\mathrm{kg}$ & 5,23 & 4,81 & 4,61 \\
\hline Aditivo & $\mathrm{ml}$ & 41,18 & 32,04 & 24,71 \\
\hline Relação a/c & & 0,42 & 0,50 & 0,62 \\
\hline $\begin{array}{l}\text { Abatimento do tronco de } \\
\text { cone (NBR 7223) }\end{array}$ & $(\mathrm{mm})$ & 6,5 & 5 & 5,5 \\
\hline $\begin{array}{l}\text { Resistência à tração na } \\
\text { flexão aos } 28 \text { dias }\end{array}$ & $\mathrm{MPa}$ & 6,57 & 5,83 & 5,06 \\
\hline $\begin{array}{l}\text { Resistência à compressão } \\
\text { simples aos } 29 \text { dias }\end{array}$ & $\mathrm{MPa}$ & 34,49 & 30,24 & 21,01 \\
\hline $\begin{array}{l}\text { Módulo de elasticidade aos } \\
28 \text { dias (a partir da leitura } \\
\text { do LVDT) }\end{array}$ & $\mathrm{MPa}$ & 29,39 & 32,50 & 30,02 \\
\hline
\end{tabular}

Os resultados apresentados na Tabela 4.7 foram obtidos através de ensaios feitos com 4 corpos de prova de cada traço no caso da tração na flexão, e 2 corpos de prova de cada traço no caso da compressão simples.

Nas Figuras 4.2 e 4.3 são apresentados graficamente os resultados relativos à resistência à tração na flexão e à resistência à compressão. O concreto com traço 1:6,5 seria suficiente para se obter a resistência média de tração na flexão de 5 MPa; entretanto, não obedece à condição da relação a/c não ser superior a 0,5 com abatimento de $55 \pm 10 \mathrm{~mm}$. Assim sendo, decidiu-se adotar, como concreto de referência, aquele com o traço 1:5,0, que apresenta resistência mecânica maior que

\footnotetext{
${ }^{10}$ Houve um engano na moldagem do concreto de traço 1:5,0 e este foi feito com teor de argamassa $47 \%$ ao invés de $48 \%$. Entretanto, devido à proximidade dos valores, considera-se que isso não prejudicou a continuidade do estudo, sendo, portanto, adotado esse valor para as dosagens que se seguiram.
} 
a mínima necessária, e relação a/c e abatimento do tronco de cone dentro dos limites desejados. Os traços confeccionados, já com a correção para substituição de agregados naturais por reciclados, são resumidos na Tabela 4.8. A relação a/c efetiva estimada foi calculada se considerando que além da umidade já presente no agregado (que foi deixado 24 horas em condição de umidade ambiente) $80 \%$ da absorção de água do agregado em 24 horas seriam efetivamente absorvidos pelos agregados na mistura do concreto.

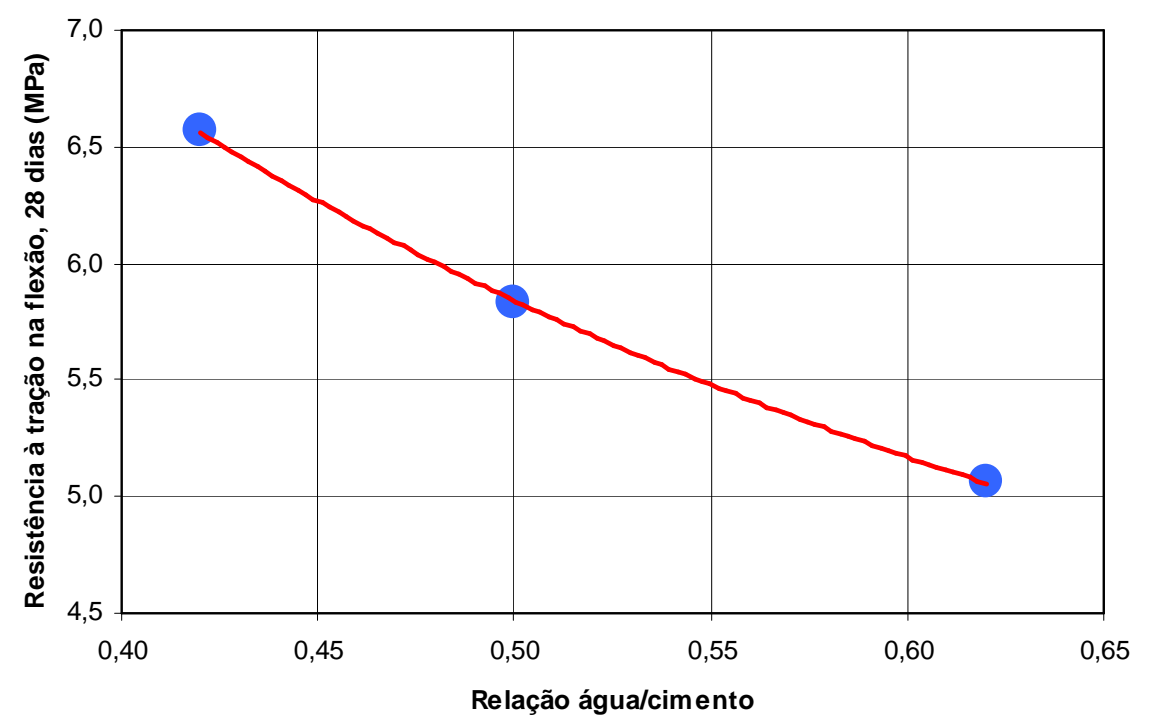

Figura 4.2 - Resistência à tração na flexão para o concreto convencional de dosagem

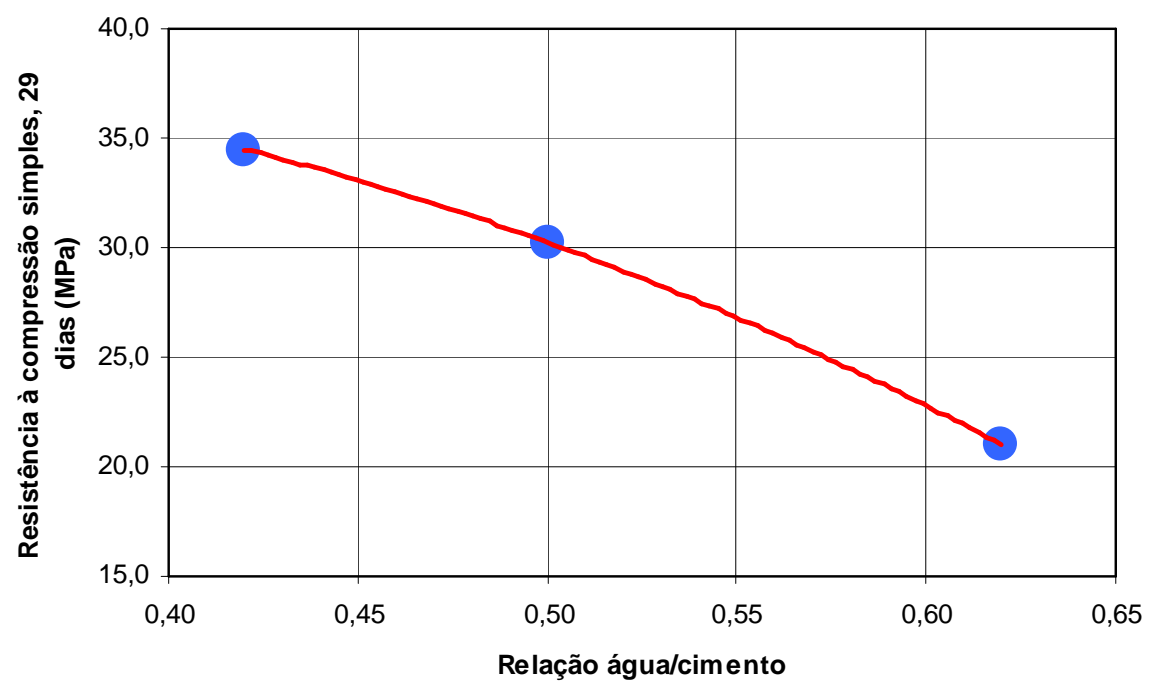

Figura 4.3 - Resistência à compressão simples para o concreto convencional de dosagem 
Tabela 4.8 - Concretos moldados para o estudo

\begin{tabular}{|c|c|c|c|c|c|c|c|c|c|c|}
\hline & & C1 & $4 / 25-F 1$ & $4 / 25-F 2$ & $4 / 25-F 3$ & 4/38-F1 & 4/38-F2 & 4/38-F3 & $4 / 25-F 2^{*}$ & $4 / 25-F 3^{*}$ \\
\hline & 1:a:p & $1: 1,80: 3,12$ & $1: 1,80: 2,67$ & 1:1,77:2,67 & $1: 1,74: 2,67$ & $1: 1,81: 2,68$ & 1:1,78:2,68 & $1: 1,75: 2,68$ & $1: 1,77: 2,67$ & $1: 1,74: 2,67$ \\
\hline Teor de argamassa & $\begin{array}{l}\% \text { em } \\
\text { massa }\end{array}$ & 47 & 0,51 & 0,51 & 0,51 & 0,51 & 0,51 & 0,51 & 0,51 & 0,51 \\
\hline Agr. graúdo convenc. & $\mathrm{kg}$ & 63,53 & - & - & - & - & - & - & - & - \\
\hline Agr. graúdo reciclado & $\mathrm{kg}$ & - & 59,63 & 59,63 & 59,63 & 59,91 & 59,91 & 59,91 & 25,68 & 25,68 \\
\hline Agregado Miúdo Total & $\mathrm{kg}$ & 36,74 & 40,28 & 39,59 & 38,89 & 40,28 & 39,62 & 38,97 & 17,05 & 16,75 \\
\hline Areia de quartzo & $\mathrm{kg}$ & 9,19 & 10,07 & 7,55 & 5,04 & 10,07 & 7,55 & 5,04 & 3,25 & 2,17 \\
\hline Areia industrial & $\mathrm{kg}$ & 27,56 & 30,21 & 22,66 & 15,11 & 30,21 & 22,66 & 15,11 & 9,76 & 6,51 \\
\hline Reciclado & $\mathrm{kg}$ & - & - & 9,37 & 18,75 & - & 9,41 & 18,82 & 4,04 & 8,08 \\
\hline Cimento & $\mathrm{kg}$ & 20,36 & 22,32 & 22,32 & 22,32 & 22,32 & 22,32 & 22,32 & 9,61 & 9,61 \\
\hline Água & $\mathrm{kg}$ & 9,92 & 13,91 & 14,21 & 14,66 & 13,16 & 12,89 & 14,16 & 6,12 & 6,31 \\
\hline Água traço 0.5 & & 9,92 & 11,16 & 11,16 & 11,16 & 11,16 & 11,16 & 11,16 & 4,81 & 4,81 \\
\hline Água adicional & & - & 2,75 & 3,05 & 3,50 & 2,00 & 1,73 & 3,00 & 1,58 & 1,51 \\
\hline Aditivo & $\mathrm{ml}$ & 67,85 & 74,39 & 74,39 & 74,39 & 74,39 & 74,39 & 74,39 & 32,04 & 32,04 \\
\hline a/c bruta & & 0,49 & 0,62 & 0,64 & 0,66 & 0,59 & 0,58 & 0,63 & 0,64 & 0,66 \\
\hline a/c efetiva estimada & & 0,49 & 0,52 & 0,51 & 0,50 & 0,47 & 0,44 & 0,47 & 0,51 & 0,50 \\
\hline $\begin{array}{l}\text { Abatimento do tronco } \\
\text { de cone (NBR 7223) }\end{array}$ & $(\mathrm{mm})$ & 5 & 4 & 5,5 & 5 & 5 & 5,5 & 5,5 & 5,5 & 5 \\
\hline Teor de ar incorporado & $\%$ & $1,40 \%$ & $2,5 \%$ ** & $2,5 \%$ & $2,4 \%$ & $1,7 \%$ & $1,4 \%$ & $1,6 \%$ & $2,6 \%$ & $2,5 \%$ \\
\hline $\begin{array}{l}\text { Massa específica do } \\
\text { concreto fresco }\end{array}$ & $\mathrm{kg} / \mathrm{m}^{3}$ & 2.399 & $2.301^{* *}$ & 2.279 & 2.265 & 2.301 & 2.279 & 2.252 & 2.268 & 2.233 \\
\hline $\begin{array}{l}\text { Quantidade de água } \\
\text { absorvida pelos agr. em } \\
24 \text { horas de imersão }\end{array}$ & $\mathrm{kg}$ & - & 2,98 & 3,61 & 4,24 & 3,23 & 3,88 & 4,54 & 1,56 & 1,83 \\
\hline $\begin{array}{l}\text { Absorção ponderada de } \\
\text { água em } 24 \text { horas }\end{array}$ & $\%$ & $0,0 \%$ & $3,2 \%$ & $3,9 \%$ & $4,6 \%$ & $3,0 \%$ & $3,6 \%$ & $4,3 \%$ & $3,9 \%$ & $4,6 \%$ \\
\hline $\begin{array}{l}\text { Consumo de cimento } \\
\text { por } \mathrm{m}^{3} \text { de concreto }\end{array}$ & $\mathrm{kg}$ & 374 & 358 & 355 & 353 & 360 & 358 & 352 & 353 & 348 \\
\hline
\end{tabular}

${ }^{*}$ moldagens adicionais a fim de repetir ensaios que não haviam sido bem executados

** valores estimados 
No concreto 4/38-F2 é possível observar que a relação a/c efetiva ficou inferior se comparada aos outros concretos. É possível que a aferição do abatimento tenha sido feita antes se comparado aos outros concretos (quando a quantidade de água livre na mistura era maior), o que possibilitaria a obtenção de um abatimento de 55 $\mathrm{mm}$ mesmo com a relação a/c efetiva final baixa. Entretanto, se essa fosse a única explicação, seria esperado que a resistência mecânica desse concreto apresentasse desempenho melhor do que o observado (item 4.12). Desconfia-se, portanto, que o agregado utilizado na mistura estivesse com maior teor de umidade que os agregados utilizados nos outros concretos (apesar do controle das condições do agregado terem sido sempre as mesmas, é possível que a estufa tenha sido desligada ou ao ser deixado em descanso antes da moldagem o agregado possa ter sido molhado por agentes externos sem que houvesse notificação de tal fato). Se esse for o ocorrido, a estimação da relação a/c efetiva estaria equivocada, já que o agregado com maior teor de umidade inicial deve, naturalmente, absorver menos quantidade de água da mistura, deixando maior quantidade de água adicional livre.

Para o concreto 4/25-F1, não foi feita a medida do teor de ar incorporado e da massa específica do concreto fresco. Para estimar o consumo de cimento deste concreto foi considerado o teor de ar incorporado como sendo o mesmo do concreto 4/25-F2 e a massa específica como sendo a mesma do concreto 4/38-F1. A adoção desses valores foi feita a partir do comportamento apresentado pelos outros concretos: haja vista que os concretos 4/25-F2 e 4/38-F2 e os concretos 4/25-F3 e 4/38-F3 apresentaram, entre si, valores de massa específica semelhantes, infere-se que os concretos 4/25-F1 e 4/38-F1 também devam possuir valores de massa específica próximos; e haja vista que nos concretos 4/38-F1, 4/38-F2 e 4/38-F3 o teor de ar incorporado não variou substancialmente, assume-se que o teor de ar incorporado dos concretos 4/25-F1, 4/25-F2 e 4/25-F3 seja semelhante. 


\subsubsection{Procedimento de mistura}

\section{Concreto convencional}

No caso do concreto convencional a mistura do concreto utilizado foi feita segundo instruções da Holcim empregadas em seu Centro Tecnológico, onde o concreto foi moldado. O procedimento engloba as seguintes etapas:

- Pesagem dos materiais, reservando em uma proveta graduada, $500 \mathrm{ml} \mathrm{da}$ água do traço para correção do abatimento após a mistura, e em outra proveta, $100 \mathrm{ml}$ para lavagem da proveta do aditivo.

- Umedecimento prévio da betoneira.

- Introdução dos agregados graúdos (em condição de umidade ambiente).

- Introdução de aproximadamente $1 / 2$ da água de amassamento e mistura por 1 minuto.

- Introdução do cimento e mistura por 1 minuto.

- Introdução do agregado miúdo (em condição de umidade ambiente) e do restante da água, e adição do aditivo. Uso dos $100 \mathrm{ml}$ para lavar a proveta e mistura por 3 minutos, observando o concreto e se necessário iniciando a correção do abatimento com a água de corte.

- Ajuste da consistência através do método do abatimento do tronco de cone, adicionando-se mais água a fim de obter a trabalhabilidade desejada.

\section{Concreto com agregados reciclados}

No caso do concreto contendo agregados reciclados se optou por seguir o método de mistura proposto por Tam et al.(2005). O procedimento seguido, incluindo algumas adaptações feitas ao procedimento proposto pelos autores, foi o seguinte:

- Pesagem dos materiais, separando a quantidade de água requerida em 2 partes iguais, separando da segunda parte: $500 \mathrm{ml}$ para correção do abatimento e $100 \mathrm{ml}$ para lavar a proveta utilizada para o aditivo 
- Umedecimento prévio da betoneira.

- Introdução dos agregados graúdos e miúdos e mistura por 1 minuto. (Os agregados reciclados, que estavam armazenados em local descoberto, foram secos em estufa a $105^{\circ} \mathrm{C}$ por aproximadamente 24 horas e depois expostos às condições ambientais em local coberto por mais aproximadamente 24 horas, a fim de simular uma condição de umidade ambiente. Os agregados convencionais foram utilizados na condição de umidade ambiente).

- Introdução de 1/2 da água e mistura por 1 minuto.

- Introdução do cimento e mistura por 30 segundos.

- Introdução de $(1 / 2-500 \mathrm{ml})$ da água e adição do aditivo utilizando $100 \mathrm{ml}$ da água para lavar a proveta) e mistura por 120 segundos.

- Ajuste da consistência através do método do abatimento do tronco de cone, adicionando-se mais água a fim de obter a trabalhabilidade desejada.

\subsubsection{Dimensões dos corpos de prova}

A ABNT NBR 7583 (1986) determina que os CP’s prismáticos de concreto a serem utilizados no controle tecnológico para pavimentação através de ensaios de tração na flexão devem ter dimensões 150x150x500 mm. Todavia, a adoção de CP's com estas dimensões implica no uso de elevadas quantidades de materiais, bem como na dificuldade de manuseio dos mesmos devido ao seu peso (aproximadamente 27 kg após desmoldados).

Em vista disso, optou-se pela utilização de CP's de dimensões 100x100x400 mm, com os quais há uma economia de cerca de $64 \%$ de material. O valor da carga requerida para a ruptura do corpo de prova fica reduzido a 34 a $39 \%$ do valor da carga requerida para o CP convencional, considerando-se que as tensões de ruptura são estatisticamente equivalentes para os dois casos. (BALBO et al., 2003; CERVO, 2004).

Para não dificultar o adensamento da massa fresca de concreto no molde, é recomendado que a dimensão dos agregados utilizados não ultrapasse $1 / 4$ da 
dimensão transversal do molde. Dessa maneira, no caso de utilização de agregados de diâmetro máximo $38 \mathrm{~mm}$, previstos nesse trabalho, não seria adequada a utilização de CP's de dimensões 100×100×400 mm. Entretanto, devido à quantidade escassa de material disponível e a questões práticas de moldagem e transportes de corpos de prova, optou-se por utilizar CP's com essa dimensão mesmo para o caso de agregados com dimensão máxima $38 \mathrm{~mm}$.

\subsubsection{Cura}

A cura dos corpos de prova foi realizada no Centro Tecnológico da Holcim Brasil segundo as instruções da norma ABNT NBR 5738 (1994).

\subsubsection{Propriedades do concreto no estado fresco}

\section{Consistência}

A trabalhabilidade do concreto foi caracterizada pelo valor do abatimento do tronco de cone determinado logo após a mistura, segundo a norma ABNT NBR NM 67 (1996) (Figura 4.4). Vale ressaltar que, como citado na revisão bibliográfica, o comportamento do concreto com respeito à trabalhabilidade em função do tempo não varia como no concreto convencional. O valor do abatimento do tronco de cone seria, portanto, somente um indicativo da real trabalhabilidade do concreto em obra, não representando fielmente a facilidade de emprego do concreto em campo. Entretanto, com as limitações de tempo e de abrangência deste trabalho, foi considerado o abatimento do tronco de cone como parâmetro para a correção da trabalhabilidade com a adição de água. 


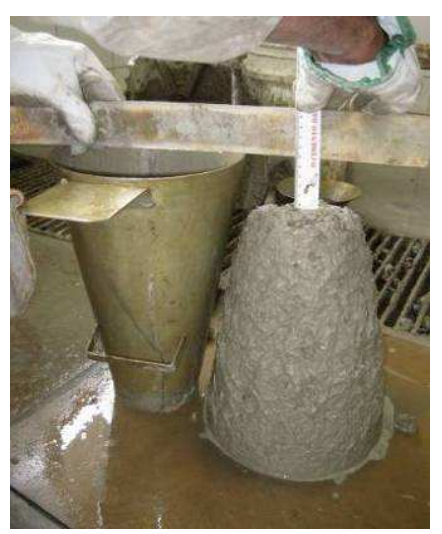

Figura 4.4 - Determinação da consistência do concreto pelo abatimento do tronco de cone

\section{Massa específica e teor de ar incorporado do concreto no estado fresco}

A determinação da massa específica do concreto no estado fresco e do teor de ar incorporado à mistura foi realizada através do método gravimétrico segundo a norma ABNT NBR 9833 (1987) (Figura 4.5).

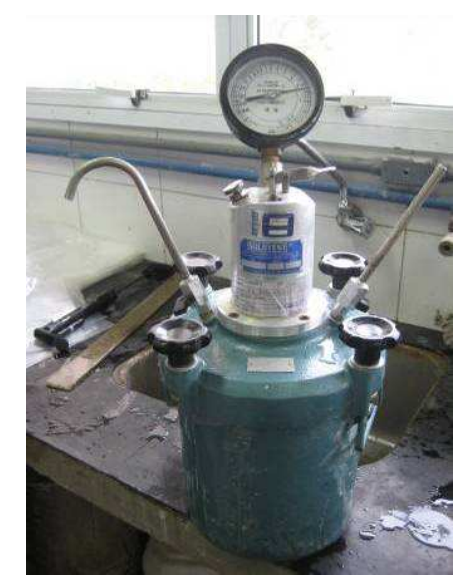

Figura 4.5 - Recipiente de medida de teor de ar incorporado

\subsubsection{Propriedades do concreto no estado endurecido}

\section{Resistência à tração na flexão $\left(\mathrm{f}_{\mathrm{ct}, \mathrm{f}}\right)$}

O ensaio de tração na flexão foi realizado seguindo a norma ABNT NBR MB-3483 (1991), que descreve o ensaio de 2 cutelos em corpo de prova prismático. Os ensaios foram realizados no Laboratório de Mecânica de Pavimentos (LMP) da EPUSP com uma prensa eletro hidráulica com carga máxima de 100 toneladas e divisão do mostrador de 0,01 tf. Para aumentar a precisão nos ensaios, foi inserida 
uma célula de carga acoplada na rótula superior, ligada a um amplificador e condicionador de sinais que transmite os dados para um software especializado (AQDADOS). A montagem da prensa para realização deste ensaio é apresentada na Figura 4.6. A resistência à tração na flexão é calculada pela expressão:

$$
f_{c t, f}=\frac{P l}{b d^{2}}
$$

onde:

$\mathrm{f}_{\mathrm{ct}, \mathrm{f}}$ : resistência à tração na flexão $(\mathrm{MPa})$

$\mathrm{P}$ : carga máxima aplicada $(\mathrm{N})$

I: distância entre cutelos de suporte $(\mathrm{mm})$

b: largura média do corpo de prova na seção de ruptura $(\mathrm{mm})$

$\mathrm{d}$ : altura média do corpo de prova na seção de ruptura $(\mathrm{mm})$
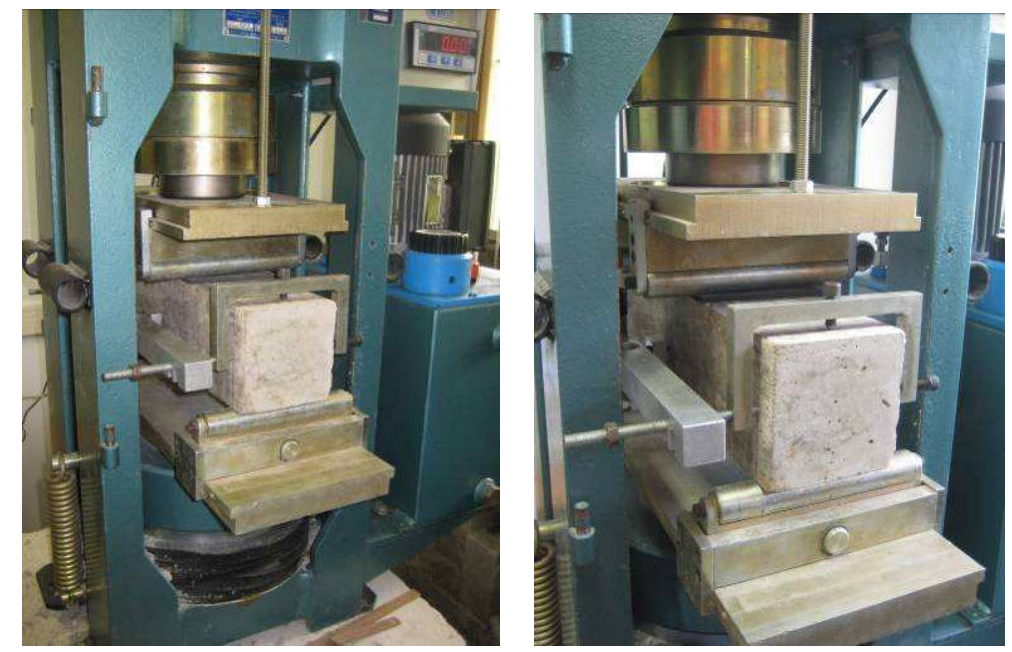

Figura 4.6 - Montagem da prensa para realização do ensaio de 2 cutelos

\section{Resistência à tração indireta $\left(\mathrm{f}_{\mathrm{ct}, \mathrm{sp}}\right)$}

O ensaio de tração indireta, ou ensaio de tração por compressão diametral, foi realizado conforme descrito na norma ABNT NBR 7222 (1994) no mesmo laboratório e com os mesmos equipamentos já descritos no ensaio anterior. A montagem da prensa para realização deste ensaio é apresentada na Figura 4.7. A resistência à tração na flexão por compressão diametral é calculada conforme a seguinte expressão: 


$$
f_{c f, s p}=\frac{2 \cdot P}{\pi \cdot d \cdot L}
$$

onde:

$f_{c f, s p}(\mathrm{MPa})$ : resistência à tração por compressão diametral

$\mathrm{P}(\mathrm{N})$ : carga máxima aplicada

$\mathrm{d}(\mathrm{mm})$ : diâmetro do corpo de prova

$L(\mathrm{~mm})$ : altura do corpo de prova
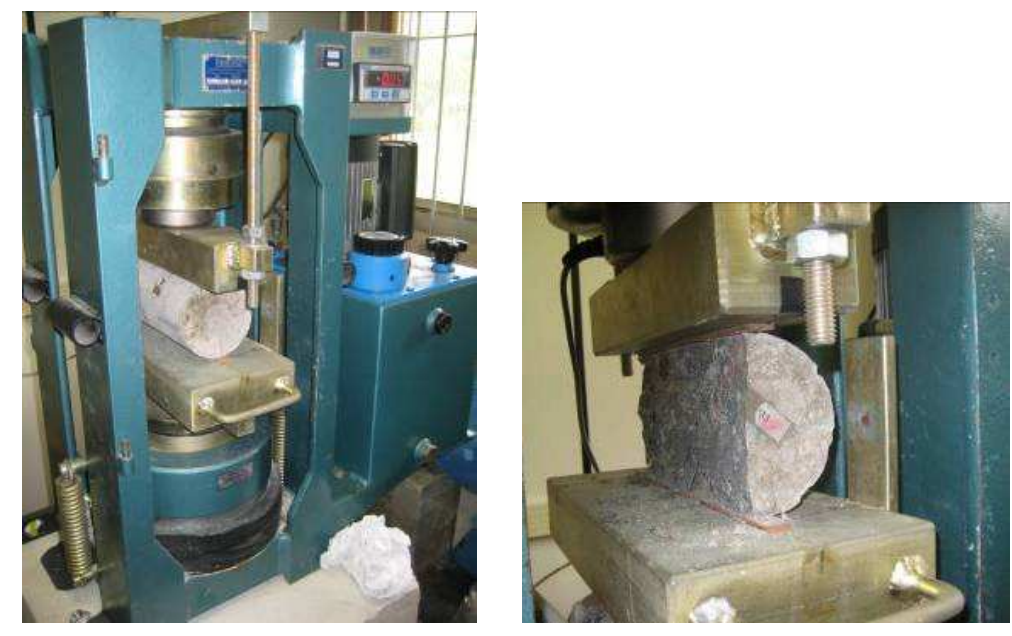

Figura 4.7 - Ensaio de tração por compressão diametral

\section{Resistência à compressão simples $\left(\mathrm{f}_{\mathrm{c}}\right)$}

Apesar da resistência à compressão do concreto não ser um fator limitante do desempenho do material quando aplicado a pavimentos de concreto, optou-se por realizar este ensaio, visto que na obra não é realizada, normalmente, nenhuma verificação do comportamento quanto à tração, por se tratar de um ensaio menos conhecido e mais complicado. Obtendo-se uma correlação entre o comportamento do material frente a esses dois modos de solicitação do material, seria possível obter um melhor controle em obra.

Os ensaios de compressão simples foram feitos conforme a norma ABNT NBR 5739 (1994). Os CP's para ensaio a 7 dias foram retificados no Laboratório de Construção Civil do Departamento de Engenharia de Construção Civil da EPUSP (Figura 4.8) e os ensaios foram realizados na prensa, já descrita, do LMP. 
Os corpos de prova para ensaio a 28 dias foram capeados com mistura de enxofre (Figura 4.9) no Centro Tecnológico da Holcim Brasil e os ensaios foram realizados neste mesmo local com prensa servo-hidráulica informatizada da marca EMIC (Figura 4.10). A tensão de ruptura à compressão é dada pela equação:

$$
\sigma_{c u}=\frac{F_{u}}{\left(\frac{\pi \cdot D^{2}}{4}\right)}
$$

onde:

$\sigma_{\mathrm{cu}}(\mathrm{MPa})$ : tensão de ruptura à compressão

$\mathrm{F}_{\mathrm{u}}(\mathrm{N})$ : carga de ruptura

$\mathrm{D}(\mathrm{mm})$ : diâmetro do CP
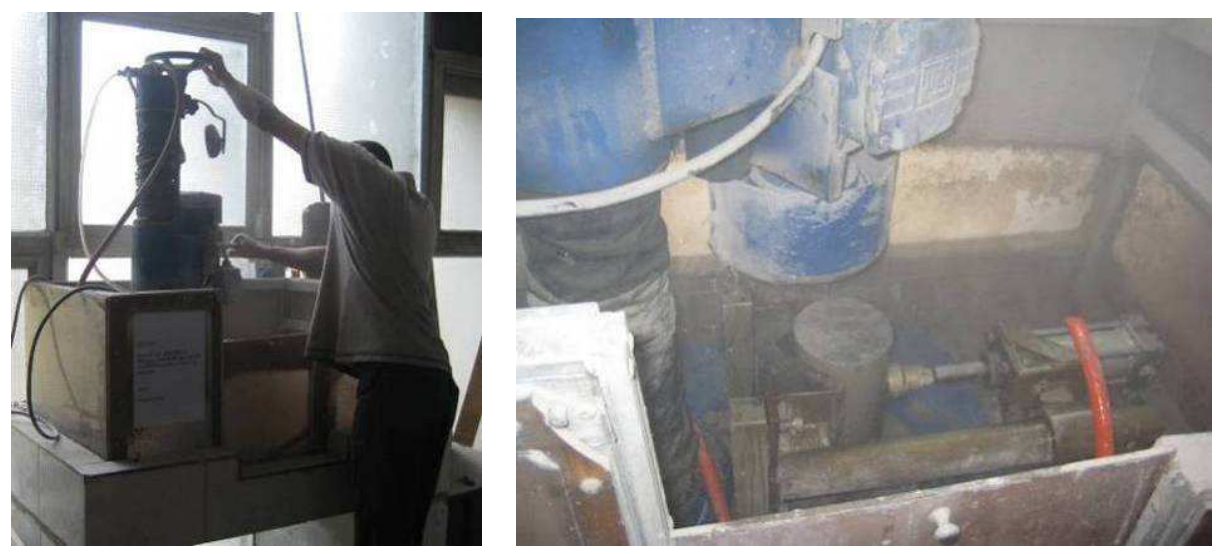

Figura 4.8 - Retificação dos corpos de prova cilíndricos para ensaio de compressão direta
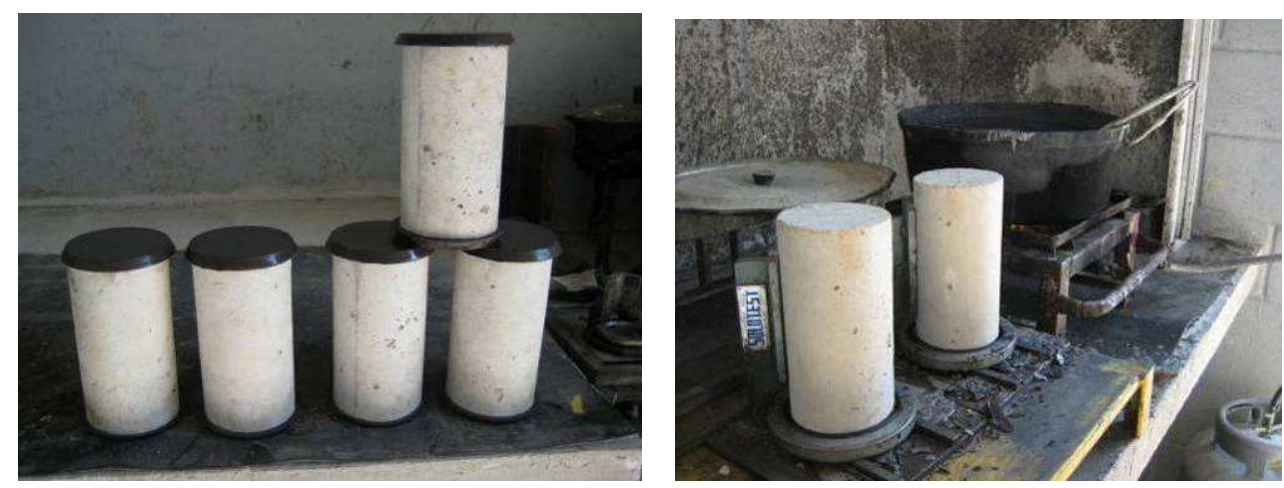

Figura 4.9 - Capeamento de corpos de prova cilíndricos para o ensaio de módulo de elasticidade à compressão com mistura de enxofre 

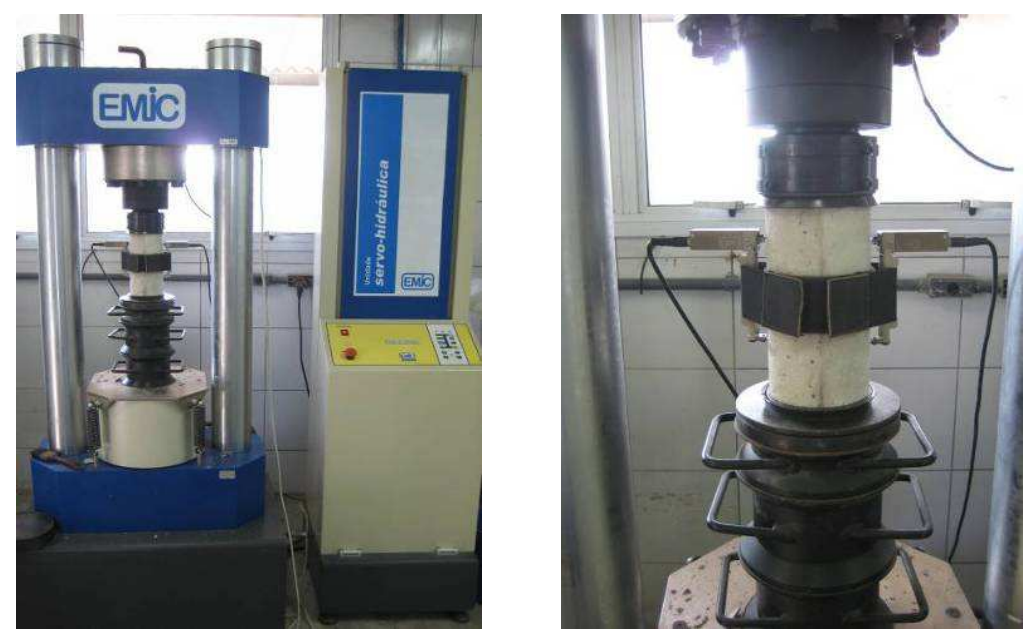

Figura 4.10 - Prensa servo-hidráulica e montagem para o ensaio de módulo de elasticidade à compressão

\section{Módulo de elasticidade estático}

O módulo de elasticidade estático obtido através do gráfico tensão versus deformação foi determinado nos ensaios de tração na flexão, de tração na compressão diametral e de compressão. No ensaio de tração na flexão foram colados strain gages no centro da superfície inferior da vigota (Figura 4.11) a fim de medir a deformação que ocorre no $\mathrm{CP}$ durante o ensaio. No ensaio de tração à compressão diametral os strain gages foram colados na superfície plana com direção perpendicular à direção de aplicação da carga (Figura 4.12).

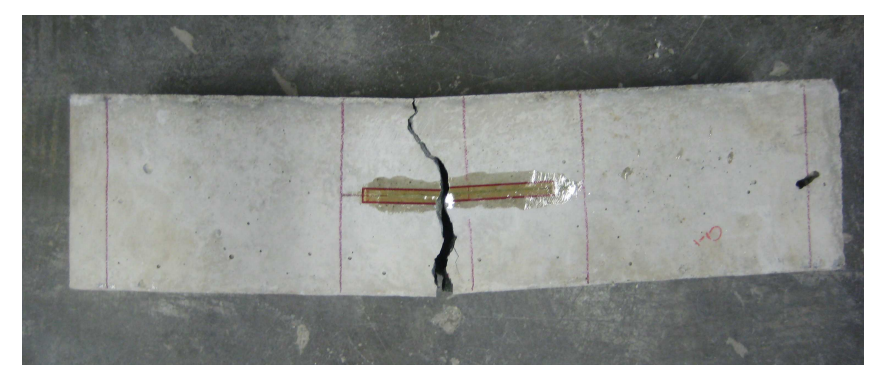

Figura 4.11 - Posicionamento do strain gage no ensaio de tração na flexão 

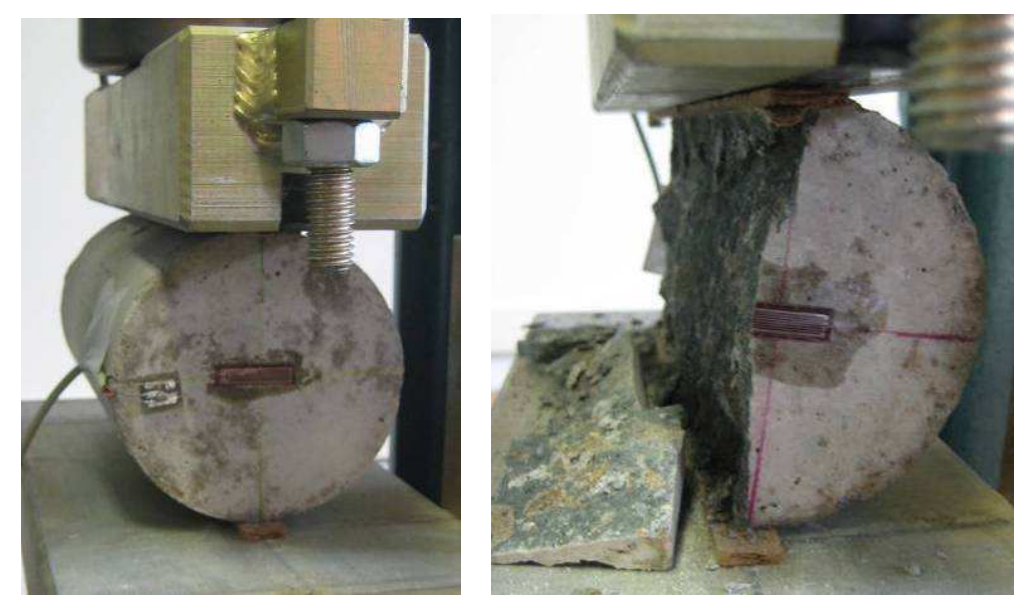

Figura 4.12 - Posicionamento do strain gage no ensaio de compressão diametral

Para o cálculo do módulo de elasticidade foram escolhidos os pontos a $5 \%$ da carga total de ruptura e a $70 \%$ da carga total de ruptura. Ou seja, o módulo de elasticidade foi tomado como sendo a declividade da corda que passa pelos pontos de tensão a $5 \%$ e a $70 \%$ da tensão máxima no gráfico "tensão x deformação", sendo obtido a partir da equação:

$$
E=\frac{\sigma_{70 \%}-\sigma_{5 \%}}{\varepsilon_{70 \%}-\varepsilon_{5 \%}}
$$

onde:

$\sigma_{70 \%}(\mathrm{MPa})$ : tensão de tração por compressão diametral a $70 \%$ da carga de ruptura; $\sigma_{5 \%}(\mathrm{MPa})$ : tensão de tração por compressão diametral a $5 \%$ da carga de ruptura; $\varepsilon_{70 \%}(\mathrm{~mm} / \mathrm{mm})$ : deformação específica de tacão a $70 \%$ da carga de ruptura; $\varepsilon_{5 \%}(\mathrm{~mm} / \mathrm{mm})$ : deformação específica de tração a $5 \%$ da carga de ruptura.

No ensaio de tração na flexão além do módulo de elasticidade estático obtido a partir da curva tensão versus deformação, foi obtido o valor do módulo de elasticidade a partir de analogia de Möhr utilizando o valor da flecha medida por um LVDT (linear variable differential transformer) posicionado no meio do vão, conforme mostra a Figura 4.13. Foi adotado para o cálculo do módulo de elasticidade, o valor da flecha medida no instante em que a carga aplicada corresponde a $70 \%$ da carga total de ruptura. 

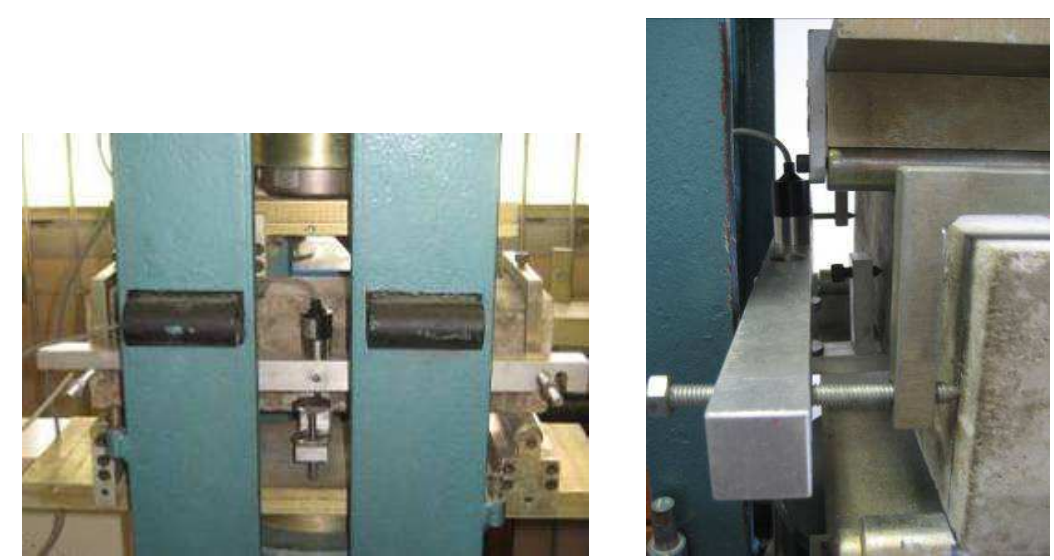

Figura 4.13 - Posicionamento do LVDT para medição da flecha durante ensaio de tração na flexão

O cálculo do módulo de elasticidade feito por analogia de Möhr resulta na seguinte expressão para o caso de um corpo de prova prismático em ensaio de tração na flexão com 2 cutelos:

$$
E=\frac{23 \cdot P \cdot I^{3}}{108 \cdot b \cdot h^{3} \cdot f}
$$

onde:

E (MPa): módulo de elasticidade do concreto no ensaio de tração na flexão

$\mathrm{P}(\mathrm{N})$ : carga

I (mm): dimensão do vão

b $(\mathrm{mm})$ : largura do corpo de prova

h (mm): altura do corpo de prova

$f(\mathrm{~mm})$ : flecha no meio do vão

Também foram obtidos valores de módulo de elasticidade à compressão com a utilização de extensômetros. Esses ensaios foram realizados em uma prensa servohidráulica EMIC do Centro Tecnológico da Holcim Brasil (Figura 4.10) de acordo com ABNT NBR 8522 (2008) utilizando a metodologia A, citada na norma. Devido à limitação de material, não foram ensaiados necessariamente 3 CP's de cada concreto para a determinação do módulo de elasticidade à compressão como previsto na norma. 


\section{Módulo de elasticidade ultrassônico}

A determinação do módulo de elasticidade ultrassônico baseia-se no conceito de que a velocidade de propagação de ondas longitudinais em um meio homogêneo e isótropo depende de constantes elásticas do material, segundo a equação:

$$
v=\sqrt{\frac{E}{\gamma}}
$$

onde:

v: velocidade de propagação de onda;

$\mathrm{Y}$ : massa específica do material

Para realização dessa medida, foi utilizado um transdutor eletroacústico, que possui um transmissor que emite ondas vibratórias ao longo do corpo de prova (emissor) e recebe os sinais pelo outro extremo (receptor) medindo com exatidão o tempo de percurso do pulso pelo concreto. A velocidade de propagação de ondas é calculada segundo a equação:

$$
v=\frac{L}{t}
$$

onde:

$v(\mathrm{~m} / \mathrm{s})$ : velocidade de propagação

$L(m)$ : distância entre os pontos de acoplamento dos centros das faces dos transdutores

t (s): tempo decorrido desde a emissão da onda até a sua recepção

A partir da velocidade de propagação das ondas obtida pela medida com 0 equipamento e pela dimensão do $\mathrm{CP}$, o cálculo do módulo de elasticidade dinâmico é conduzido segundo a eq.(30) (KOMLOS et al., 1996).

$$
E_{d}=\gamma \cdot v^{2} \cdot \frac{(1+v) \cdot(1-2 v)}{(1-v)}
$$

onde:

$E_{d}$ : módulo de elasticidade dinâmico (MPa); 
v: velocidade longitudinal de propagação de onda $(\mathrm{km} / \mathrm{s})$;

$\mathrm{Y}$ : massa específica do material $\left(\mathrm{kg} / \mathrm{m}^{3}\right)$

$v$ : coeficiente de Poisson

Sendo este um método não destrutivo e relativamente simples para a obtenção de um valor teórico de módulo de elasticidade para o concreto, este ensaio foi realizado para todos os concretos estudados. A medição foi realizada posicionando os transdutores nas faces paralelas mais distantes dos corpos de prova, tanto cilíndricos como prismáticos, e respeitando as instruções da ABNT NBR 8802 (1994) (Figura 4.14).

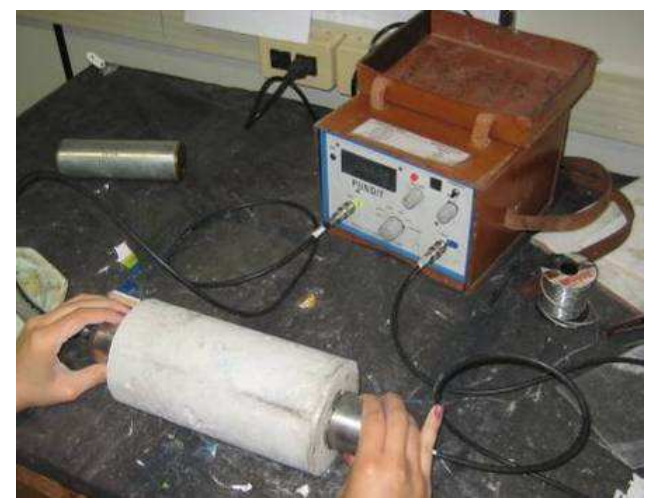

Figura 4.14 - Obtenção do módulo de elasticidade através da leitura do tempo de transmissão de onda no CP

\subsection{APRESENTAÇÃO E DISCUSSÃO DOS RESULTADOS}

\subsubsection{Ensaio de tração na flexão}

Os resultados dos ensaios de tração na flexão, aos 7 e aos 28 dias, são apresentados nas Tabelas 4.9 e 4.10 . 
Tabela 4.9 - Resultados obtidos no ensaio de tração na flexão aos 7 dias

\begin{tabular}{|c|c|c|c|c|}
\hline & Tensão de ruptura & Tensão de ruptura média & E (LVDT) & $\overline{\bar{E}}$ (LVDT) \\
\hline & $(\mathrm{MPa})$ & $(\mathrm{MPa})$ & (GPa) & (GPa) \\
\hline \multirow{3}{*}{$\mathrm{C} 1$} & 5,2 & \multirow{3}{*}{5,3} & 24 & \multirow{3}{*}{25} \\
\hline & 5,4 & & 26 & \\
\hline & 5,3 & & 25 & \\
\hline \multirow{3}{*}{$4 / 25-\mathrm{F} 1$} & 4,9 & \multirow{3}{*}{4,9} & 19 & \multirow{3}{*}{23} \\
\hline & 4,9 & & 25 & \\
\hline & 5,0 & & 24 & \\
\hline \multirow{3}{*}{$4 / 25-F 2$} & 4,4 & \multirow{3}{*}{4,5} & 20 & \multirow{3}{*}{25} \\
\hline & 4,5 & & 30 & \\
\hline & 4,8 & & 25 & \\
\hline \multirow{3}{*}{$4 / 25-F 3$} & 4,9 & \multirow{3}{*}{4,7} & 22 & \multirow{3}{*}{22} \\
\hline & 4,4 & & 23 & \\
\hline & 4,9 & & 22 & \\
\hline \multirow{3}{*}{ 4/38-F1 } & 5,0 & \multirow{3}{*}{5,1} & - & \multirow{3}{*}{23} \\
\hline & 5,6 & & 25 & \\
\hline & 4,7 & & 21 & \\
\hline \multirow{3}{*}{ 4/38-F2 } & 4,9 & \multirow{3}{*}{4,8} & 17 & \multirow{3}{*}{22} \\
\hline & 4,8 & & - & \\
\hline & 4,5 & & 27 & \\
\hline \multirow{3}{*}{ 4/38-F3 } & 4,1 & \multirow{3}{*}{4,5} & - & \multirow{3}{*}{21} \\
\hline & 4,4 & & 23 & \\
\hline & 5,0 & & 20 & \\
\hline
\end{tabular}


Tabela 4.10 - Resultados obtidos no ensaio de tração na flexão aos 28 dias

\begin{tabular}{|c|c|c|c|c|c|c|}
\hline & $\begin{array}{l}\text { Tensão de } \\
\text { ruptura }\end{array}$ & $\begin{array}{l}\text { Tensão de } \\
\text { ruptura média }\end{array}$ & E (LVDT) & $\begin{array}{l}\text { E médio } \\
\text { (LVDT) }\end{array}$ & $E$ (SG) & $\bar{E}(\mathrm{SG})$ \\
\hline & (MPa) & (MPa) & (GPa) & (GPa) & (GPa) & (GPa) \\
\hline \multirow{4}{*}{ C1 } & 5,4 & \multirow{4}{*}{5,5} & 28 & \multirow{4}{*}{26} & 27 & \multirow{4}{*}{29} \\
\hline & 5,1 & & 25 & & $24^{*}$ & \\
\hline & 5,7 & & - & & 26 & \\
\hline & 6,0 & & - & & 38 & \\
\hline \multirow{3}{*}{ 4/25-F1 } & 5,2 & \multirow{3}{*}{5,3} & 23 & \multirow{3}{*}{23} & 23 & \multirow{3}{*}{27} \\
\hline & 5,6 & & 22 & & 29 & \\
\hline & 5,2 & & - & & $28^{*}$ & \\
\hline \multirow{3}{*}{ 4/25-F2 } & 4,8 & \multirow{4}{*}{4,8} & 23 & \multirow{4}{*}{23} & 26 & \multirow{4}{*}{22} \\
\hline & 4,5 & & 23 & & 21 & \\
\hline & 4,7 & & - & & 20 & \\
\hline 4/25-F2' & 5,0 & & - & & 22 & \\
\hline \multirow{4}{*}{ 4/25-F3 } & 4,6 & \multirow{6}{*}{4,6} & 25 & \multirow{6}{*}{23} & 21 & \multirow{6}{*}{22} \\
\hline & 4,6 & & 22 & & 23 & \\
\hline & 4,7 & & 21 & & 23 & \\
\hline & 4,3 & & 24 & & $25^{\star}$ & \\
\hline \multirow{2}{*}{ 4/25-F3' } & 4,5 & & - & & 19 & \\
\hline & 4,8 & & 23 & & 19 & \\
\hline \multirow{4}{*}{ 4/38-F1 } & 4,9 & \multirow{4}{*}{5,0} & 17 & \multirow{4}{*}{22} & 17 & \multirow{4}{*}{19} \\
\hline & 4,8 & & - & & 18 & \\
\hline & 5,4 & & 20 & & 19 & \\
\hline & 4,9 & & 27 & & 21 & \\
\hline \multirow{4}{*}{ 4/38-F2 } & 4,7 & \multirow{4}{*}{4,4} & 21 & \multirow{4}{*}{22} & 17 & \multirow{4}{*}{20} \\
\hline & 4,2 & & - & & 21 & \\
\hline & 4,1 & & 13 & & 19 & \\
\hline & 4,6 & & 31 & & 23 & \\
\hline \multirow{4}{*}{ 4/38-F3 } & 4,3 & \multirow{4}{*}{4,5} & 14 & \multirow{4}{*}{23} & 20 & \multirow{4}{*}{28} \\
\hline & 4,5 & & 27 & & 26 & \\
\hline & 4,9 & & 27 & & $31^{*}$ & \\
\hline & 4,4 & & 24 & & 34 & \\
\hline
\end{tabular}

* valores obtidos a partir de pontos da curva "tensão x deformação" que não correspondem aos $5 \% \mathrm{e}$ aos $70 \%$ da carga total de ruptura; considerando-se somente a parte da curva que se apresentou consistente (em alguns gráficos a curva apresentou sinuosidades, que provavelmente se devem ao fato de a cola não ter secado completamente antes da realização do ensaio)

\section{Resistência à tração na flexão}

Nas Figuras 4.15 e 4.16 são apresentados os valores médios, máximos e mínimos de resistência à tração na flexão encontrados aos 7 e aos 28 dias em função da absorção ponderada dos agregados (graúdos e miúdos) utilizados na mistura do concreto. 


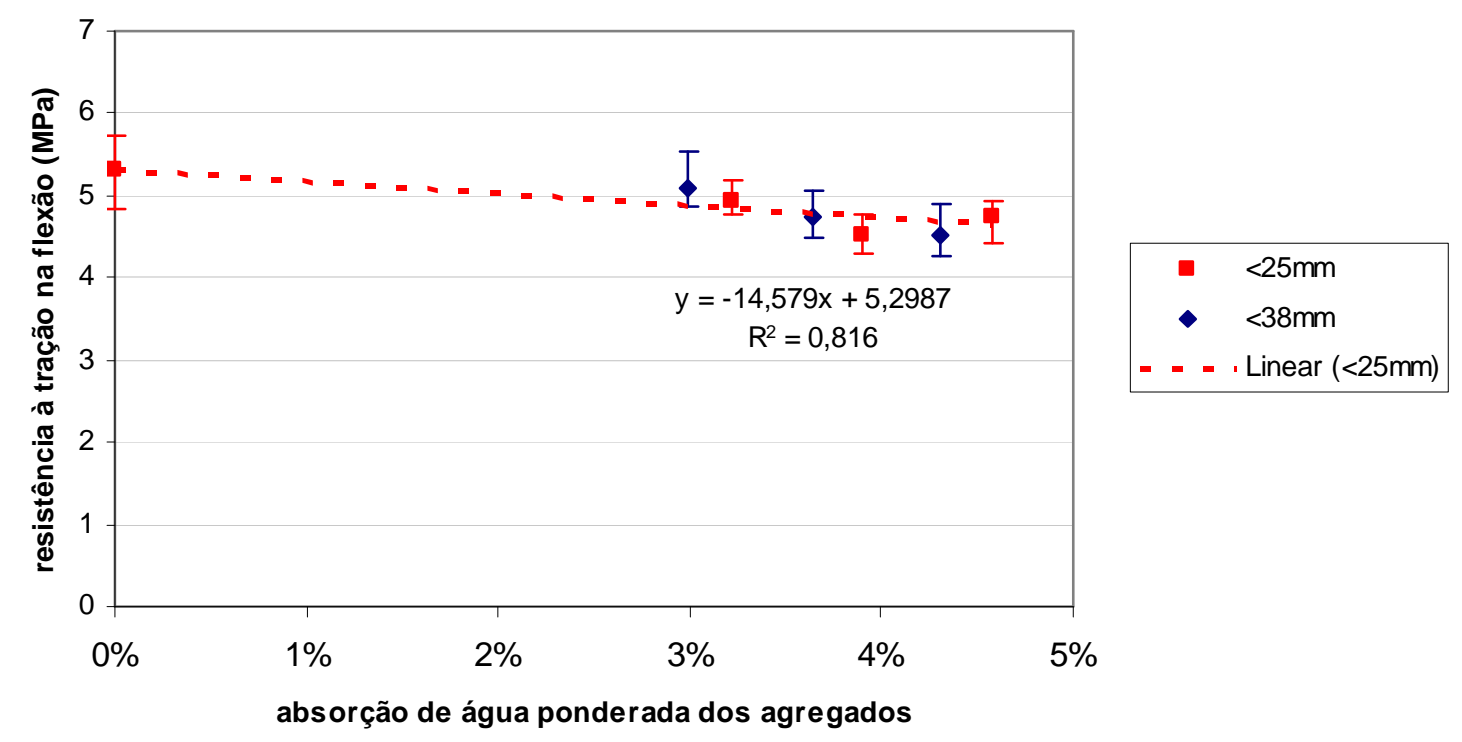

Figura 4.15 - Resistência a tração na flexão média aos 7 dias em função da absorção de água ponderada dos agregados

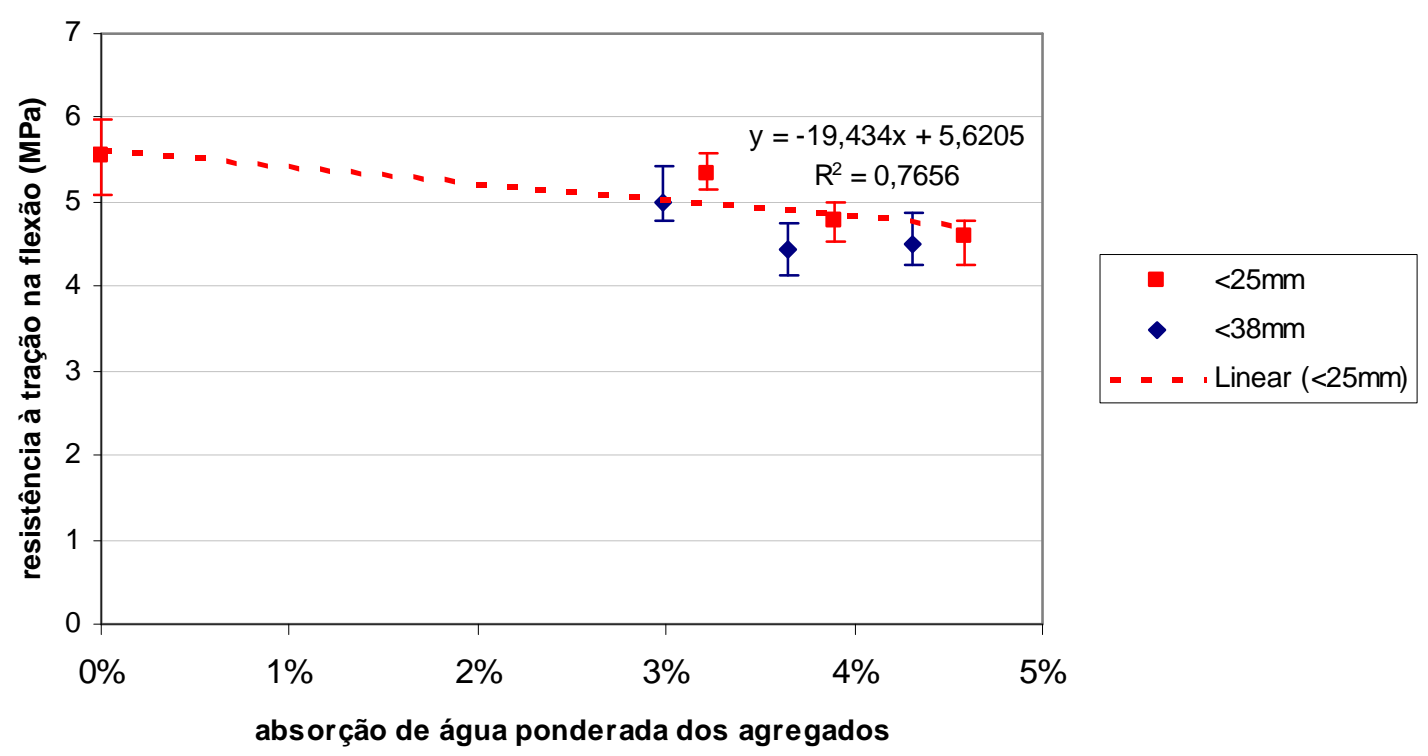

Figura 4.16 - Resistência à tração na flexão média aos 28 dias em função da absorção de água ponderada dos agregados

Observa-se que a substituição dos agregados naturais por reciclados resulta em perda de resistência à tração na flexão. A perda aumenta conforme se aumenta a absorção de água ponderada dos agregados utilizados na mistura. Os valores médios de resistência à tração na flexão encontrados para o concreto com agregados de dimensão máxima $25 \mathrm{~mm}$ em função da absorção de água ponderada dos agregados podem ser razoavelmente correlacionados através de uma reta com $R^{2}=0,82$ aos 7 dias e $R^{2}=0,77$ aos 28 dias. 
Com a substituição dos agregados de dimensão máxima $25 \mathrm{~mm}$ por aqueles de 38 $\mathrm{mm}$ a resistência à tração na flexão do concreto observada não varia de maneira importante para o mesmo teor de substituição de agregados. Pode-se notar que os valores encontrados estão próximos da reta de correlação traçada para concretos de dimensão máxima do agregado $25 \mathrm{~mm}$.

Na Figura 4.17 os resultados obtidos para o concreto com agregados de dimensão máxima $25 \mathrm{~mm}$ são comparados a dados obtidos na literatura, sendo os pontos em verde correspondentes à utilização de agregados graúdos reciclados e os pontos em azul correspondentes à utilização de agregados miúdos e graúdos reciclados. Observa-se que os valores encontrados no presente trabalho são elevados se comparados aos encontrados no estudo de Yang et al. (2008), em que também foram utilizados agregados miúdos reciclados.

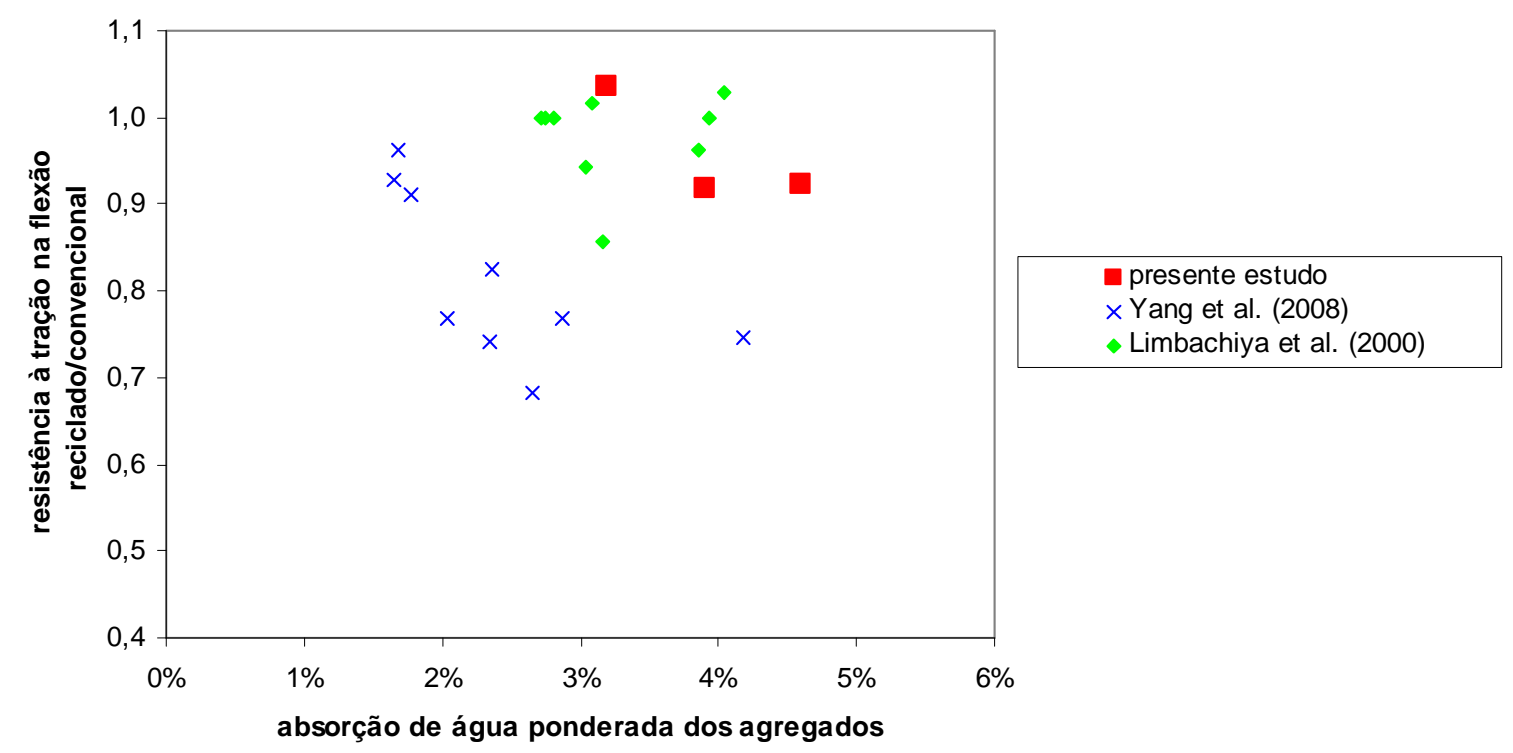

Figura 4.17 - relação entre resistência à tração na flexão dos concretos reciclado e convencional em função da absorção ponderada dos agregados

\section{Módulo de elasticidade obtido por analogia de Möhr}

Os valores médios, máximos e mínimos de módulo de elasticidade encontrados a partir das medições das flechas no meio do vão dos corpos de prova são apresentados nas Tabelas 4.9 e 4.10 e nas Figuras 4.18 e 4.19 . 


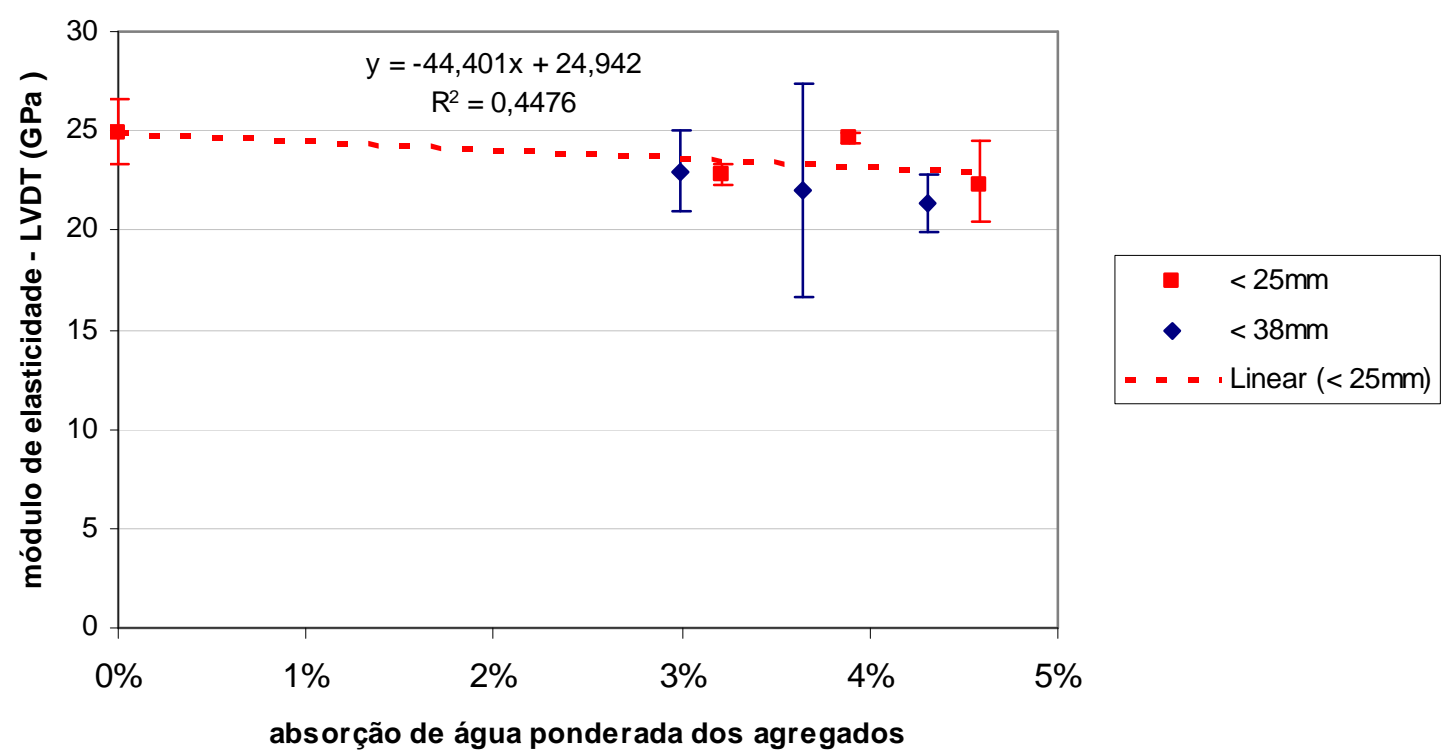

Figura 4.18 - Módulo de elasticidade aos 7 dias calculado a partir da flecha do CP MP ensaio de tração na flexão em função da absorção ponderada dos agregados

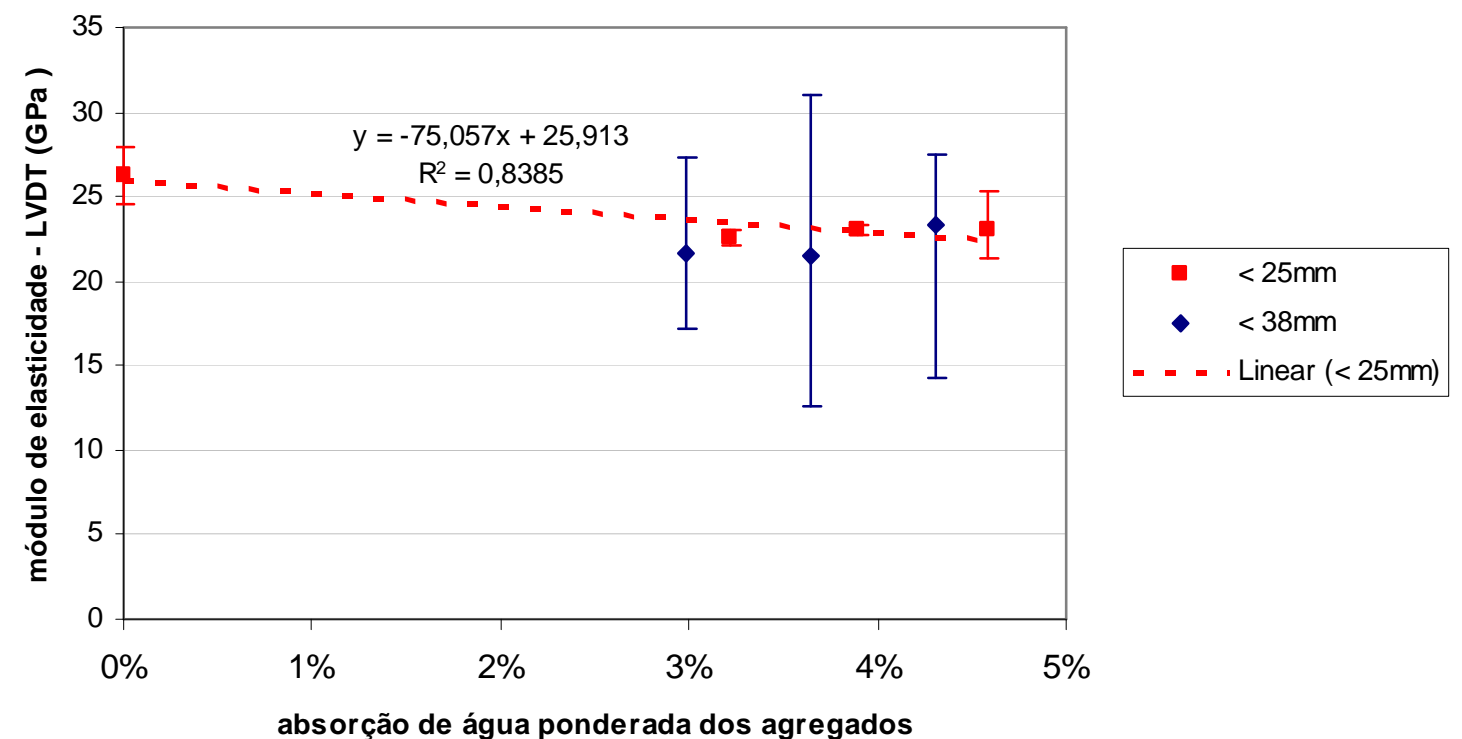

Figura 4.19 - Módulo de elasticidade aos 28 dias calculado a partir da flecha do CP no ensaio de tração na flexão em função da absorção ponderada dos agregados

Nos concretos com agregados de dimensão máxima $25 \mathrm{~mm}$ é notada uma queda nos valores de módulo de elasticidade encontrados com a substituição do agregado natural por reciclado. Com a substituição de parte dos agregados miúdos naturais por reciclados o módulo de elasticidade apresentou-se muito similar àquele apresentado pelos concretos em que somente os agregados graúdos foram substituídos. Nos ensaios realizados com os concretos com agregado de dimensão 
máxima $38 \mathrm{~mm}$ a medida da flecha no meio do vão variou substancialmente, o que se deve, provavelmente, a uma possível falha nas medições.

\section{Módulo de elasticidade obtido através da curva tensão versus deformação}

Na Figura 4.20 são apresentados os valores médios, máximos e mínimos de módulo de elasticidade aos 28 dias calculados a partir da curva tensão versus deformação obtidas no ensaio de tração na flexão em função da absorção de água ponderada dos agregados.

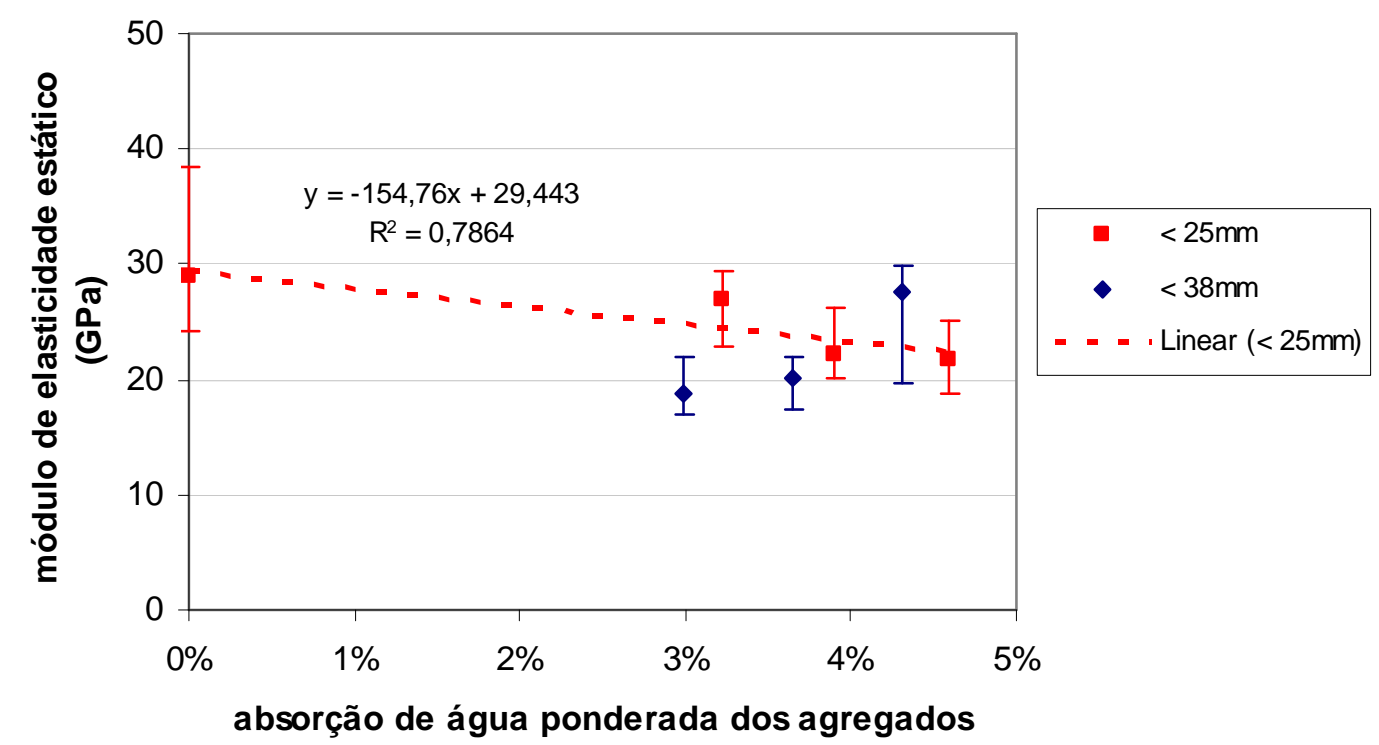

Figura 4.20 - Módulo de elasticidade aos 28 dias calculado a partir da curva tensão versus deformação obtida no ensaio de tração na flexão em função da absorção ponderada dos agregados

Apesar da grande variação nos resultados, para os concretos de dimensão máxima do agregado $25 \mathrm{~mm}$ a absorção de água ponderada dos agregados e as médias dos módulos de elasticidade estático encontrados podem ser correlacionados por uma reta de coeficiente de $R^{2}=0,786$. Nos concretos com agregados reciclados de dimensão máxima $38 \mathrm{~mm}$ os resultados apresentam grande variação, permanecendo razoavelmente próximos aos valores encontrados para os concretos com mesmo teor de substituição de agregados e com dimensão máxima do agregado $25 \mathrm{~mm}$.

A queda no módulo de elasticidade com o aumento da absorção de água ponderada dos agregados pode ser explicada por um menor módulo de elasticidade da pasta 
de cimento em relação ao agregado natural. A maior presença de pasta de cimento (pasta antiga mais pasta nova) no concreto contendo agregados reciclados leva a um menor módulo de elasticidade do concreto, já que este valor depende do módulo de elasticidade das partes que o compõe.

\subsubsection{Ensaio de tração na compressão diametral}

Nas Tabelas 4.11 e 4.12 são apresentados os resultados obtidos nos ensaios de tração na compressão diametral aos 7 e aos 28 dias.

Tabela 4.11- Resultados obtidos no ensaio de tração na compressão diametral aos 7 dias

\begin{tabular}{|c|c|c|}
\hline & Tensão de ruptura & Tensão de ruptura média \\
\hline & $(\mathrm{MPa})$ & $(\mathrm{MPa})$ \\
\hline \multirow{3}{*}{ C1 } & 4,0 & \multirow{3}{*}{4,2} \\
\hline & 4,0 & \\
\hline & 4,4 & \\
\hline \multirow{3}{*}{$4 / 25-\mathrm{F} 1$} & 3,0 & \multirow{3}{*}{3,9} \\
\hline & 4,1 & \\
\hline & 4,5 & \\
\hline \multirow{3}{*}{ 4/25-F2 } & 3,6 & \multirow{3}{*}{3,6} \\
\hline & 3,5 & \\
\hline & 3,7 & \\
\hline \multirow{3}{*}{ 4/25-F3 } & 3,2 & \multirow{3}{*}{3,0} \\
\hline & 2,7 & \\
\hline & 2,9 & \\
\hline \multirow{3}{*}{ 4/38-F1 } & 3,6 & \multirow{3}{*}{4,0} \\
\hline & 4,2 & \\
\hline & 4,1 & \\
\hline \multirow{3}{*}{ 4/38-F2 } & 4,1 & \multirow{3}{*}{4,3} \\
\hline & 4,7 & \\
\hline & 4,1 & \\
\hline \multirow{3}{*}{ 4/38-F3 } & 4,1 & \multirow{3}{*}{4,0} \\
\hline & 3,7 & \\
\hline & 4,2 & \\
\hline
\end{tabular}


Tabela 4.12 - Resultados obtidos no ensaio de tração na compressão diametral aos 28 dias

\begin{tabular}{|c|c|c|c|c|}
\hline & Tensão de ruptura & $\begin{array}{c}\text { Tensão de ruptura } \\
\text { média }\end{array}$ & E & $\overline{\mathbf{E}}$ \\
\hline & (MPa) & (MPa) & (GPa) & (GPa) \\
\hline \multirow{3}{*}{ C1 } & 4,9 & \multirow{3}{*}{4,7} & 26 & \multirow{3}{*}{23} \\
\hline & 4,7 & & 14 & \\
\hline & 4,6 & & 28 & \\
\hline \multirow{3}{*}{ 4/25-F1 } & 4,9 & \multirow{3}{*}{4,1} & 18 & \multirow{3}{*}{18} \\
\hline & 3,2 & & - & \\
\hline & 4,2 & & 18 & \\
\hline \multirow{4}{*}{ 4/25-F2 } & 4,1 & \multirow{6}{*}{4,0} & - & \multirow{6}{*}{11} \\
\hline & 3,5 & & - & \\
\hline & 4,4 & & $12^{*}$ & \\
\hline & 3,9 & & 9 & \\
\hline \multirow{2}{*}{ 4/25-F2' } & 2,6 & & 7 & \\
\hline & 3,8 & & 14 & \\
\hline \multirow{3}{*}{$4 / 25-F 3$} & 3,2 & \multirow{6}{*}{3,4} & $6^{*}$ & \multirow{6}{*}{11} \\
\hline & 4,5 & & - & \\
\hline & 2,6 & & - & \\
\hline \multirow{3}{*}{ 4/25-F3' } & 4,5 & & 14 & \\
\hline & 4,2 & & 10 & \\
\hline & 4,3 & & 12 & \\
\hline \multirow{3}{*}{ 4/38-F1 } & 4,2 & \multirow{3}{*}{4,0} & 10 & \multirow{3}{*}{10} \\
\hline & 4,3 & & 13 & \\
\hline & 3,6 & & 7 & \\
\hline \multirow{3}{*}{ 4/38-F2 } & 4,4 & \multirow{3}{*}{4,5} & 10 & \multirow{3}{*}{10} \\
\hline & 4,6 & & 9 & \\
\hline & 4,7 & & 12 & \\
\hline \multirow{3}{*}{ 4/38-F3 } & 5,0 & \multirow{3}{*}{4,2} & 14 & \multirow{3}{*}{11} \\
\hline & 3,5 & & 7 & \\
\hline & 4,0 & & 13 & \\
\hline
\end{tabular}

* valores obtidos a partir de pontos da curva "tensão x deformação" que não correspondem aos $5 \% \mathrm{e}$ aos $70 \%$ da carga total de ruptura; considerando-se somente a parte da curva que se apresentou consistente (em alguns gráficos a curva apresentou sinuosidades, que provavelmente se devem ao fato de a cola não ter secado completamente antes da realização do ensaio)

\section{Resistência à tração na compressão diametral}

Nas Figuras 4.21 e 4.22 são apresentados os valores médios, máximos e mínimos de resistência à tração na compressão dos concretos estudados em função da absorção de água ponderada dos agregados utilizados. 


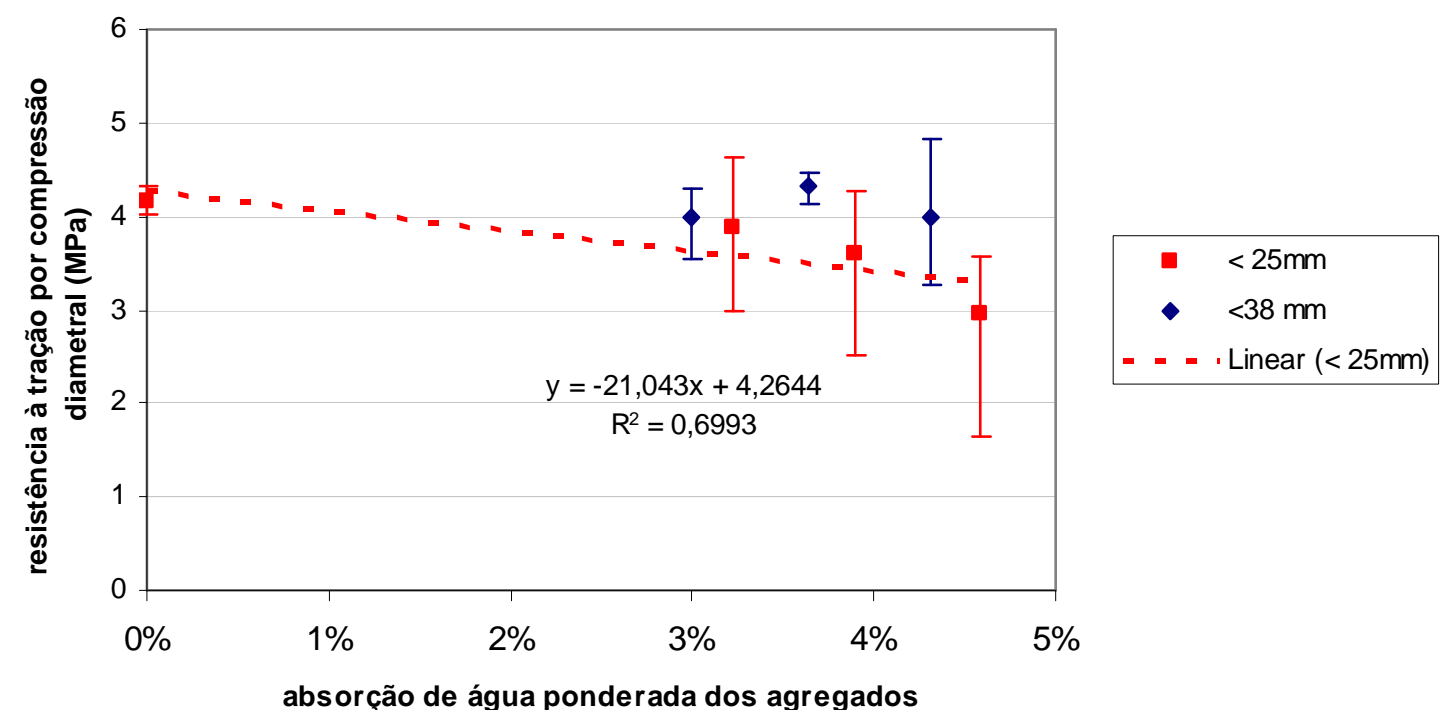

Figura 4.21 - Resistência à tração indireta aos 7 dias

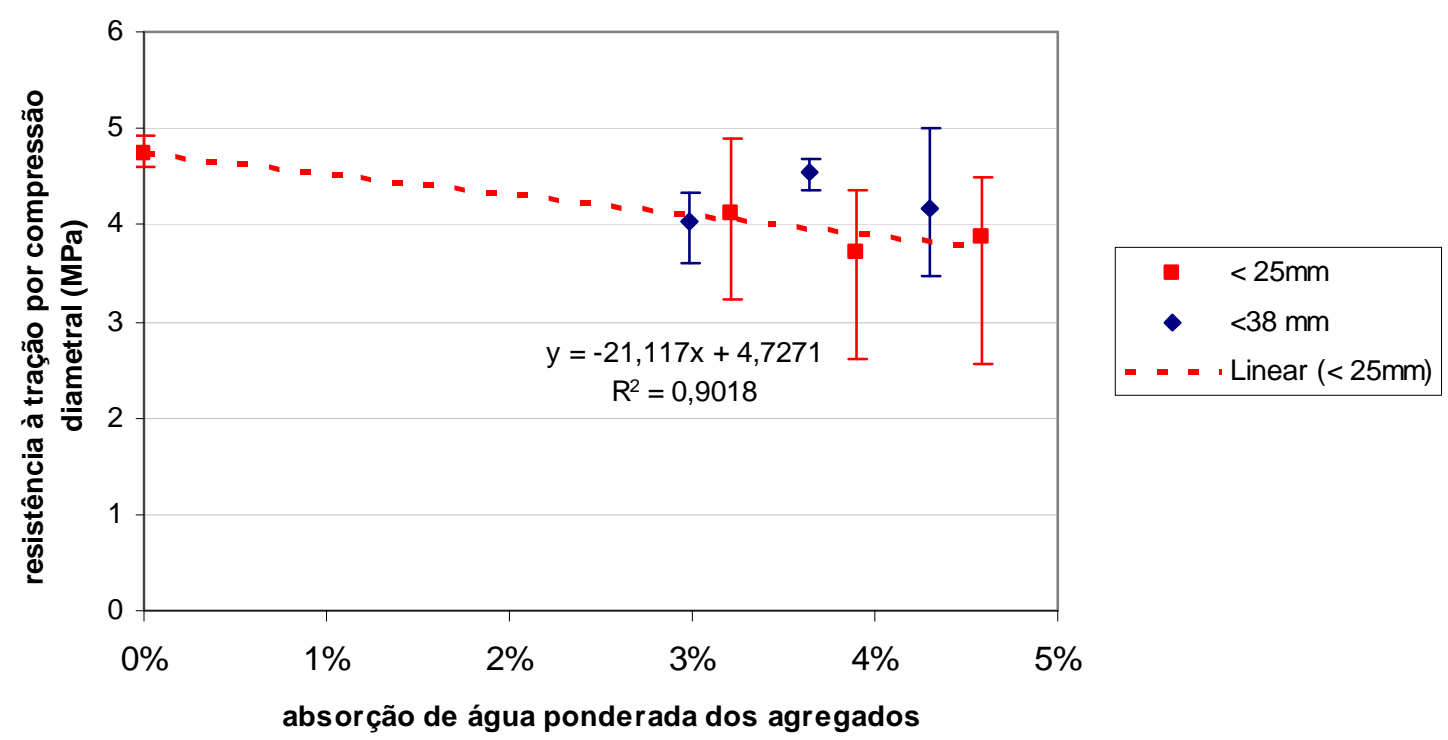

Figura 4.22 - Resistência à tração indireta aos 28 dias

Os valores encontrados nos ensaios de tração na compressão diametral apresentam grande variação. Observa-se, no geral, que assim como no caso da resistência à tração na flexão, existe uma queda de resistência à tração na compressão diametral com a substituição de agregados naturais por reciclados. As médias dos valores obtidos permitem uma correlação linear razoável, com $R^{2}=0,70$ aos 7 dias e $R^{2}=0,90$ aos 28 dias.

Na Figura 4.23 os resultados obtidos para o concreto com agregados de dimensão máxima $25 \mathrm{~mm}$ do presente estudo são comparados a dados obtidos na literatura, sendo os pontos em verde correspondentes à utilização de agregados graúdos 
reciclados e os pontos em azul correspondentes à utilização de agregados miúdos e graúdos reciclados.

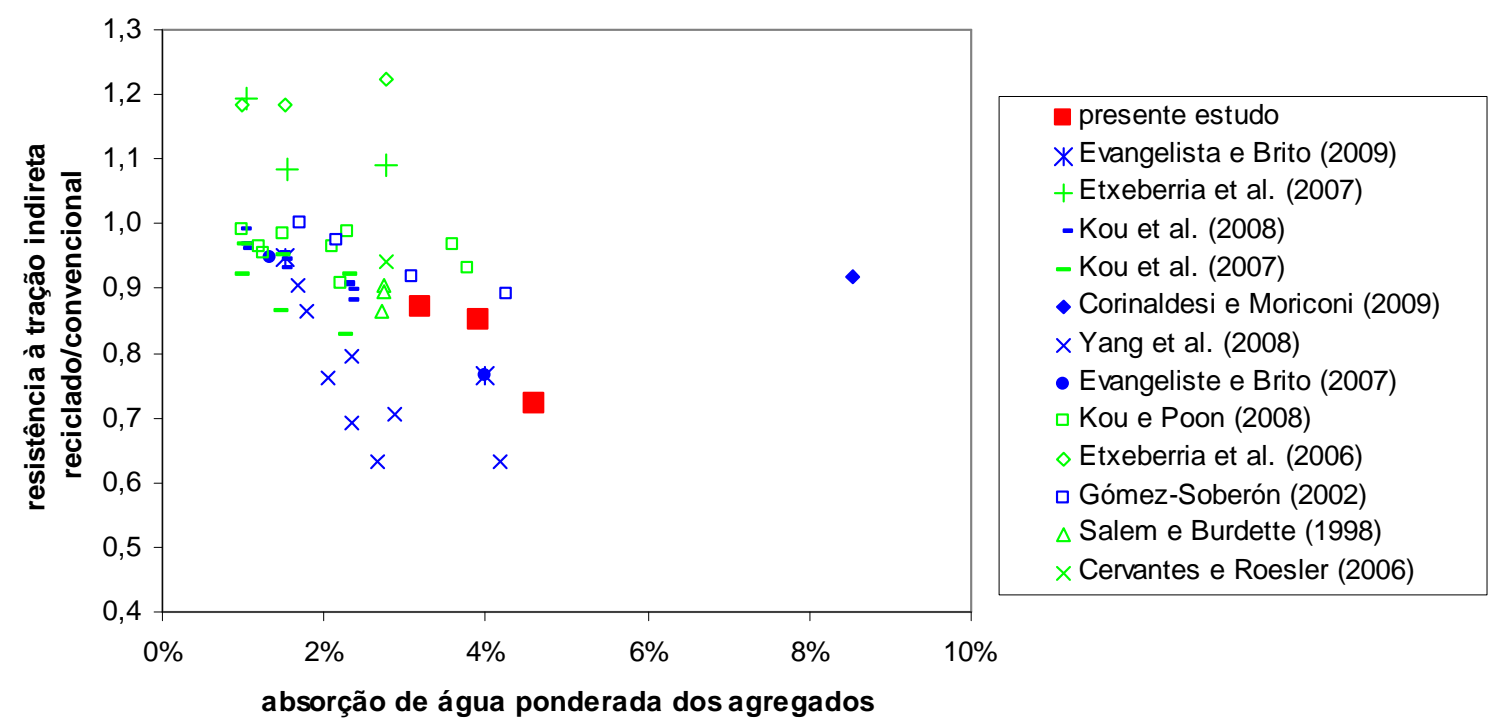

Figura 4.23 - relação entre resistência à tração na compressão diametral dos concretos reciclado e convencional em função da absorção ponderada dos agregados

Pode-se concluir que os resultados obtidos nesse trabalho são coerentes com os encontrados na literatura, e que para a maioria dos estudos consultados, observa-se também uma queda de resistência à tração indireta conforme se aumenta o valor de absorção de água ponderada dos agregados. Além disso, nota-se que há uma tendência de para um mesmo valor de absorção de água ponderada os concretos contendo agregados miúdos reciclados apresentarem resistência inferior aos concretos contendo somente agregados graúdos reciclados.

\section{Módulo de elasticidade obtido através da curva tensão versus deformação}

$\mathrm{Na}$ Figura 4.24 são apresentados os valores médios, máximos e mínimos dos módulos de elasticidade aos 28 dias calculados a partir da curva tensão versus deformação obtida no ensaio de compressão diametral em função da absorção de água ponderada dos agregados. 


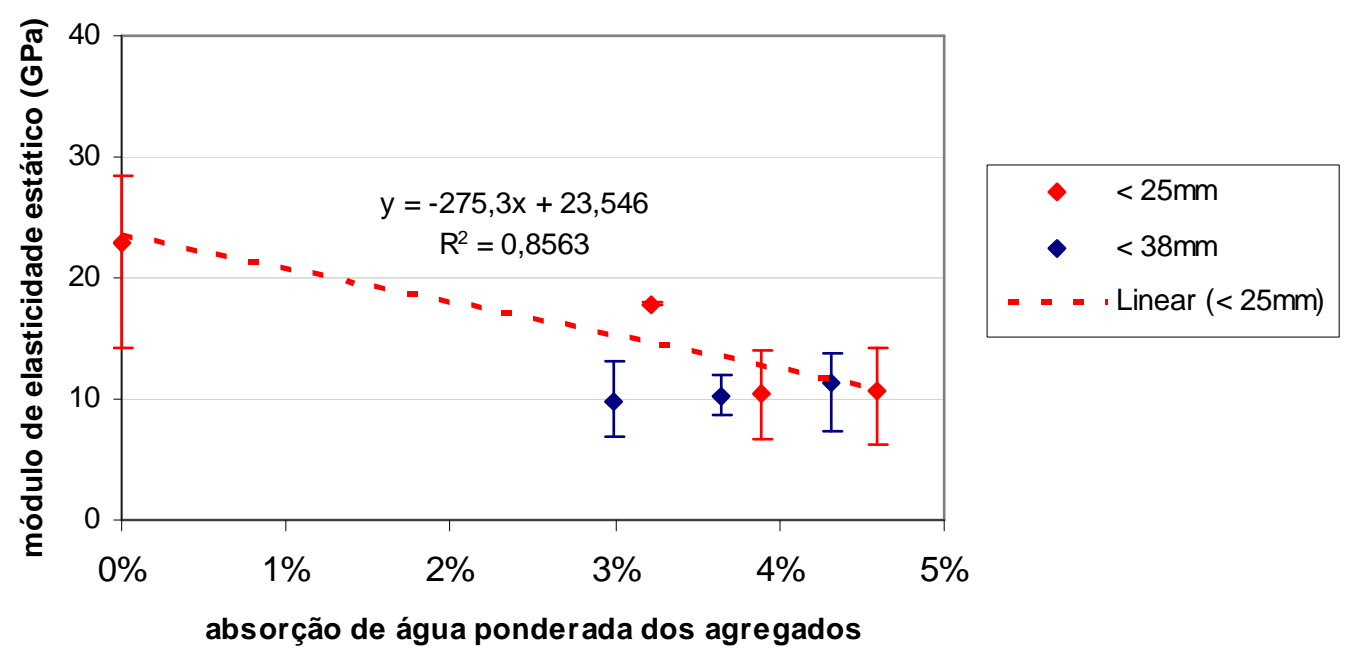

Figura 4.24 - Módulo de elasticidade aos 28 dias calculado a partir da curva tensão versus deformação obtida no ensaio de tração indireta em função da absorção ponderada

No concreto com agregados de dimensão máxima $25 \mathrm{~mm}$ o módulo de elasticidade obtido no ensaio de tração na compressão diametral apresenta queda com a substituição dos agregados naturais por reciclados, assim como foi observado no ensaio de tração na flexão. Nos concretos com agregados de dimensão máxima 38 mm não foi possível observar mudança considerável no módulo de elasticidade estático conforme se aumento ou teor de substituição de agregados.

\subsubsection{Ensaio de compressão}

Os valores de resistência à compressão e módulo de elasticidade na compressão encontrados aos 7 e 28 dias são apresentados nas Tabelas 4.13 e 4.14 . Foram considerados, para o cálculo da média da resistência à compressão, os valores encontrados ao se romper os corpos de prova no ensaio de módulo de elasticidade estático à compressão (como a velocidade de carregamento com a qual o CP rompe é a mesma nos dois ensaios foi considerado que a possível diferença de comportamento devido aos ciclos de carregamento-descarregamento no ensaio de módulo de elasticidade não alteraria significantemente o valor de resistência final). 
Tabela 4.13 - Resultados obtidos no ensaio de compressão simples aos 7 dias

\begin{tabular}{|c|c|c|}
\hline & Tensão de ruptura & Tensão de ruptura média \\
\hline & (MPa) & $(\mathrm{MPa})$ \\
\hline \multirow{3}{*}{ C1 } & 30,6 & \multirow{3}{*}{28,4} \\
\hline & 28,4 & \\
\hline & 26,2 & \\
\hline \multirow{3}{*}{$4 / 25-F 1$} & 30,6 & \multirow{3}{*}{29,2} \\
\hline & 29,9 & \\
\hline & 27,1 & \\
\hline \multirow{3}{*}{ 4/25-F2 } & 25,2 & \multirow{3}{*}{24,8} \\
\hline & 25,6 & \\
\hline & 23,7 & \\
\hline \multirow{3}{*}{ 4/25-F3 } & 28,5 & \multirow{3}{*}{24,2} \\
\hline & 26,3 & \\
\hline & 17,9 & \\
\hline \multirow{3}{*}{ 4/38-F1 } & 35,8 & \multirow{3}{*}{36,1} \\
\hline & 33,8 & \\
\hline & 38,7 & \\
\hline \multirow{3}{*}{ 4/38-F2 } & 37,1 & \multirow{3}{*}{36,2} \\
\hline & 35,8 & \\
\hline & 35,8 & \\
\hline \multirow{3}{*}{ 4/38-F3 } & 32,8 & \multirow{3}{*}{32,4} \\
\hline & 34,2 & \\
\hline & 30,3 & \\
\hline
\end{tabular}


Tabela 4.14 - Resultados obtidos no ensaio de compressão simples e módulo de elasticidade na compressão aos 28 dias

\begin{tabular}{|c|c|c|c|c|}
\hline & Tensão de ruptura & Tensão de ruptura média & $E$ & $\bar{E}$ \\
\hline & (MPa) & (MPa) & (GPa) & (GPa) \\
\hline \multirow{3}{*}{ C1 } & 40,0 & \multirow{3}{*}{41,1} & - & \multirow{3}{*}{23} \\
\hline & 40,8 & & - & \\
\hline & 42,6 & & 23 & \\
\hline \multirow{4}{*}{$4 / 25-\mathrm{F} 1$} & 45,4 & \multirow{4}{*}{42,6} & - & \multirow{4}{*}{21} \\
\hline & 41,1 & & - & \\
\hline & 43,3 & & 22 & \\
\hline & 40,8 & & 20 & \\
\hline \multirow{3}{*}{ 4/25-F2 } & 36,5 & \multirow{3}{*}{37,7} & - & \multirow{3}{*}{21} \\
\hline & 38,7 & & - & \\
\hline & 37,9 & & 21 & \\
\hline \multirow{4}{*}{$4 / 25-F 3$} & 38,1 & \multirow{4}{*}{37,9} & - & \multirow{4}{*}{22} \\
\hline & 37,3 & & - & \\
\hline & 38,2 & & 22 & \\
\hline & 37,9 & & 22 & \\
\hline \multirow{5}{*}{ 4/38-F1 } & 43,1 & \multirow{5}{*}{44,9} & - & \multirow{5}{*}{23} \\
\hline & 45,0 & & - & \\
\hline & 46,7 & & 24 & \\
\hline & 44,6 & & 23 & \\
\hline & 45,2 & & 23 & \\
\hline \multirow{4}{*}{$4 / 38-F 2$} & 43,2 & \multirow{4}{*}{42,8} & - & \multirow{4}{*}{23} \\
\hline & 44,4 & & - & \\
\hline & 44,0 & & 24 & \\
\hline & 39,7 & & 23 & \\
\hline \multirow{6}{*}{ 4/38-F3 } & 41,0 & \multirow{6}{*}{42,4} & - & \multirow{6}{*}{22} \\
\hline & 44,1 & & - & \\
\hline & 42,0 & & - & \\
\hline & 41,1 & & 22 & \\
\hline & 43,0 & & 23 & \\
\hline & 43,0 & & 21 & \\
\hline
\end{tabular}

\section{Resistência à compressão}

Os valores médios, máximos e mínimos de resistência à compressão encontrados em função da absorção de água ponderada dos agregados são resumidos nas Figuras 4.25 e 4.26 . 


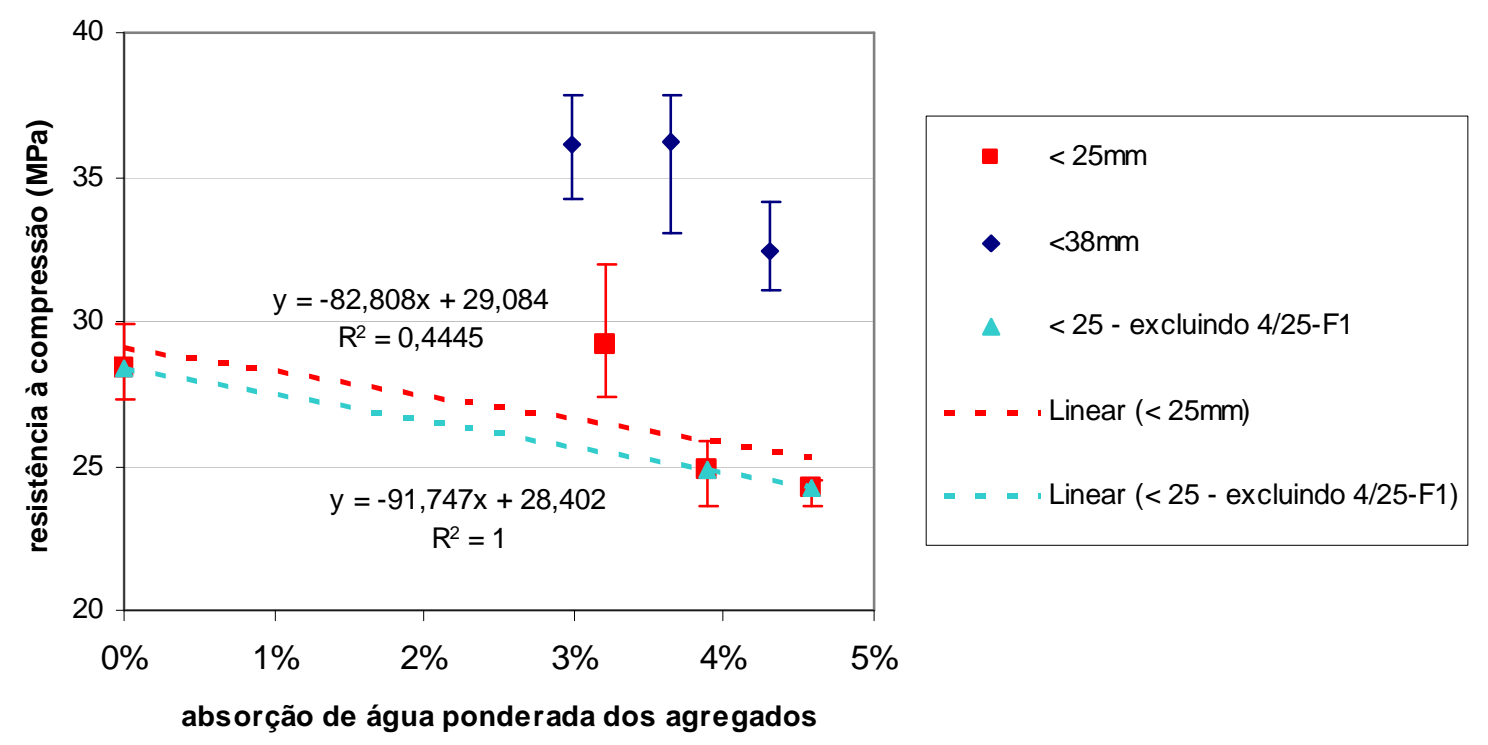

Figura 4.25 - Resistência à compressão aos 7 dias

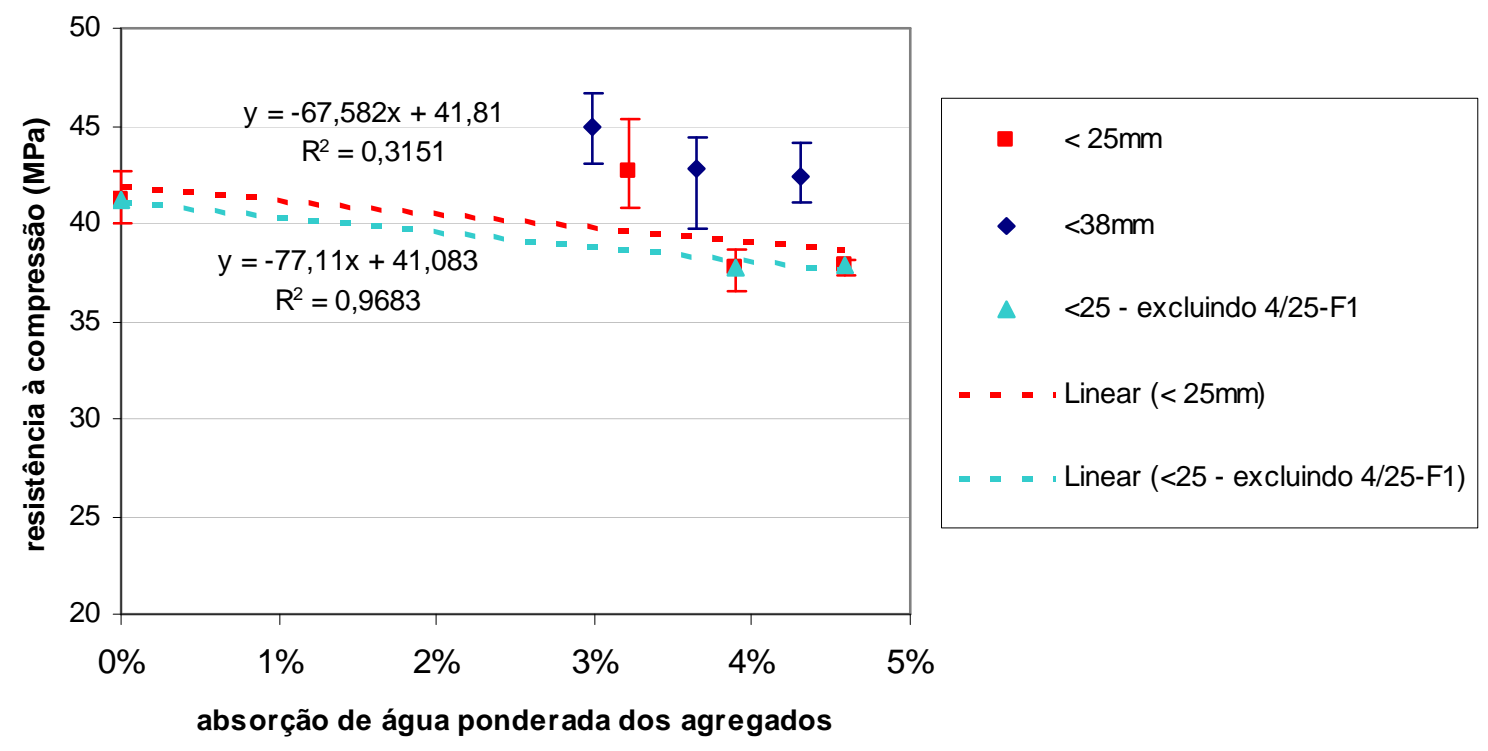

Figura 4.26 - Resistência à compressão aos 28 dias

No concreto 4/25-F1, em que foram substituídos somente agregados graúdos, a resistência à compressão encontrada foi maior que a do concreto de controle. No caso dos concretos 2/25-F2 e 4/25-F3 o comportamento foi similar ao comportamento observado na tração, a resistência à compressão diminui conforme se aumenta o teor de substituição dos agregados. Desconsiderando-se o ponto correspondente ao concreto 4/25-F1, que foi o único a não apresentar a mesma 
tendência de queda de resistência à compressão com aumento da absorção de água dos agregados, consegue-se correlacionar os pontos linearmente com altos coeficientes de correlação $\left(R^{2}=1\right.$ aos 7 dias e $R^{2}=0,97$ aos 28 dias).

Os concretos feitos com agregados de dimensão máxima $38 \mathrm{~mm}$ apresentaram resistência à compressão consideravelmente maior que os concretos com agregados de dimensão máxima $25 \mathrm{~mm}$. E similarmente aos concretos com agregados de dimensão máxima $25 \mathrm{~mm}$, apresentaram queda de resistência à compressão conforme ocorre aumento da absorção de água ponderada dos agregados.

Mehta e Monteiro (2008) afirmam que para um mesmo consumo de cimento e uma mesma consistência, dosagens de concreto com agregados maiores requerem menos água de amassamento; ou seja, com o uso de partículas maiores é possível obter a consistência desejada com uma menor relação a/c efetiva. Isso pode ser observado na Tabela 4.8, em que foi apresentada a relação a/c efetiva das misturas ao se considerar que $80 \%$ da absorção de água dos agregados em 24 horas foi efetivamente absorvida. Nota-se que nos concretos contendo agregados de dimensão máxima $38 \mathrm{~mm}$ as relações a/c efetivas são menores se comparadas àquelas dos concretos com agregados de dimensão máxima $25 \mathrm{~mm}$. A pasta de cimento com menor relação a/c efetiva, portanto menos porosa, explicaria a maior resistência à compressão do concreto com dimensão máxima do agregado 38 mm.

Outro efeito do emprego de agregados de maior dimensão, segundo Mehta e Monteiro (2008), é a formação de uma zona de transição na interface mais fraca, contendo mais microfissuras. Haja vista o comportamento observado, é possível que o efeito desse comportamento no concreto com dimensão máxima do agregado $38 \mathrm{~mm}$ tenha sido menos sentido pela resistência à compressão que o efeito da diminuição da relação a/c efetiva na pasta de cimento. No que se refere à resistência à tração, entretanto, a melhor resistência da pasta de cimento nova pode não ter sido tão importante para a resistência mecânica do conjunto. Haja vista a porosidade e microfissuração presente nos agregados reciclados e a tendência de formação de uma zona de interface mais fraca com uso de agregados maiores, o efeito de concentração de tensões nos defeitos quando o concreto é submetido a 
esforços de tração pode ter ocasionado um desempenho do concreto com agregados de dimensão máxima $38 \mathrm{~mm}$ não tão eficaz à tração quanto à compressão, como foi observado.

È importante ressaltar que apesar do estudo em questão focar a influência da maior porosidade dos agregados na resistência mecânica dos concretos, é possível que alguns fatores que não foram controlados também tenham influenciado a resistência mecânica dos concretos, tais como a forma, a textura e a granulometria dos agregados, tanto graúdos ${ }^{11}$ como miúdos.

A Figura 4.27 apresenta a relação resistência à compressão entre concreto reciclado e convencional em função da absorção de água ponderada dos agregados encontrada em diversos estudos, inclusive neste trabalho. Os pontos em verde correspondem à utilização de agregados graúdos reciclados e os pontos em azul correspondentes à utilização de agregados miúdos e graúdos reciclados.
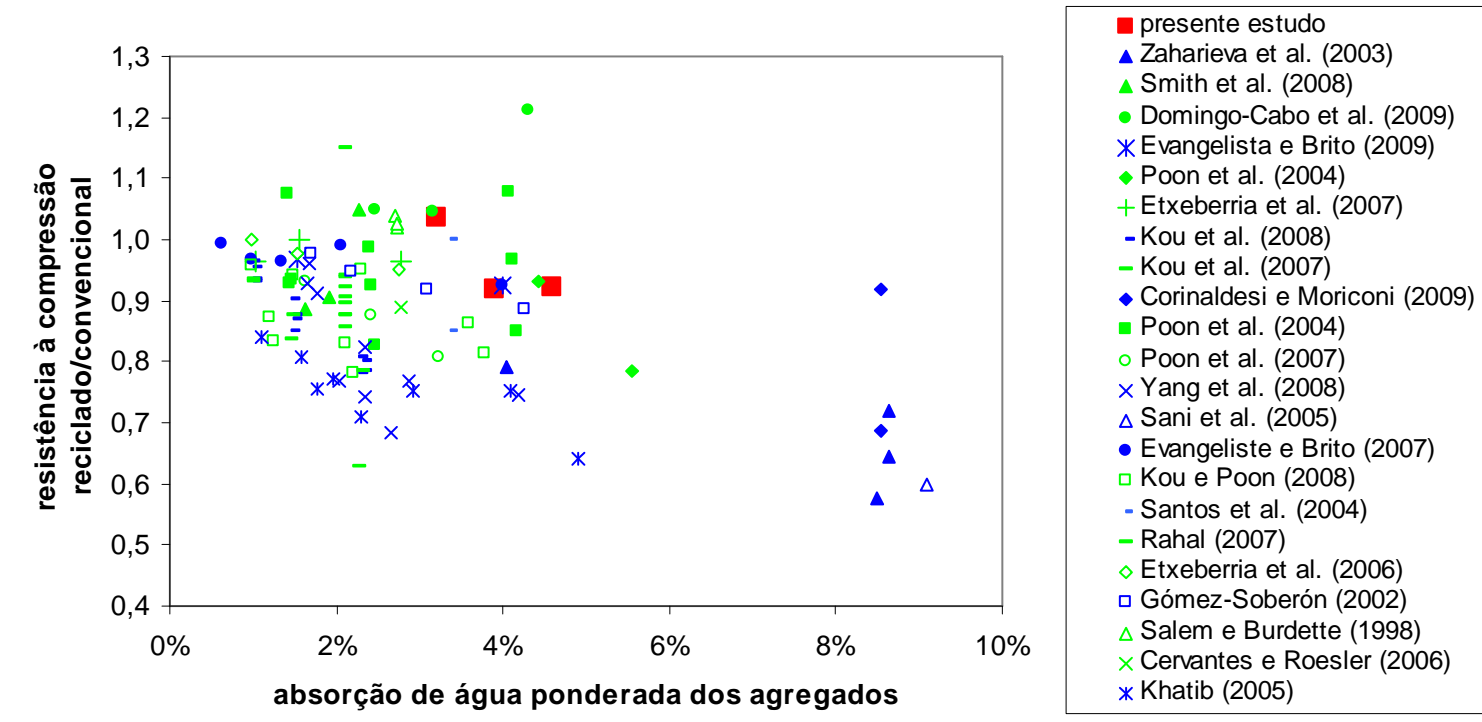

Figura 4.27- Relação entre resistência à compressão dos concretos reciclado e convencional em função da absorção ponderada dos agregados

Assim como o comportamento observado em relação à resistência à tração, a relação entre resistência à compressão do concreto reciclado e do concreto

\footnotetext{
${ }^{11}$ Apesar de ter sido feita a composição da curva granulométrica dos agregados naturais para reproduzir aquela dos reciclados, o procedimento é feito por faixas granulométricas, não sendo, portanto, exato.
} 
convencional diminui conforme se aumenta a absorção de água ponderada dos agregados. Os valores encontrados nesse trabalho indicam uma boa relação resistência à compressão reciclado/convencional se comparado com a maioria dos estudos apresentados, que com valores de absorção de água ponderada semelhantes apresentam menores valores de relação entre resistências.

\section{Módulo de elasticidade obtido através da curva tensão versus deformação}

Os valores médios, máximos e mínimos de módulo de elasticidade estático em compressão em função da absorção de água ponderada dos agregados são resumidos na Figura 4.28 .

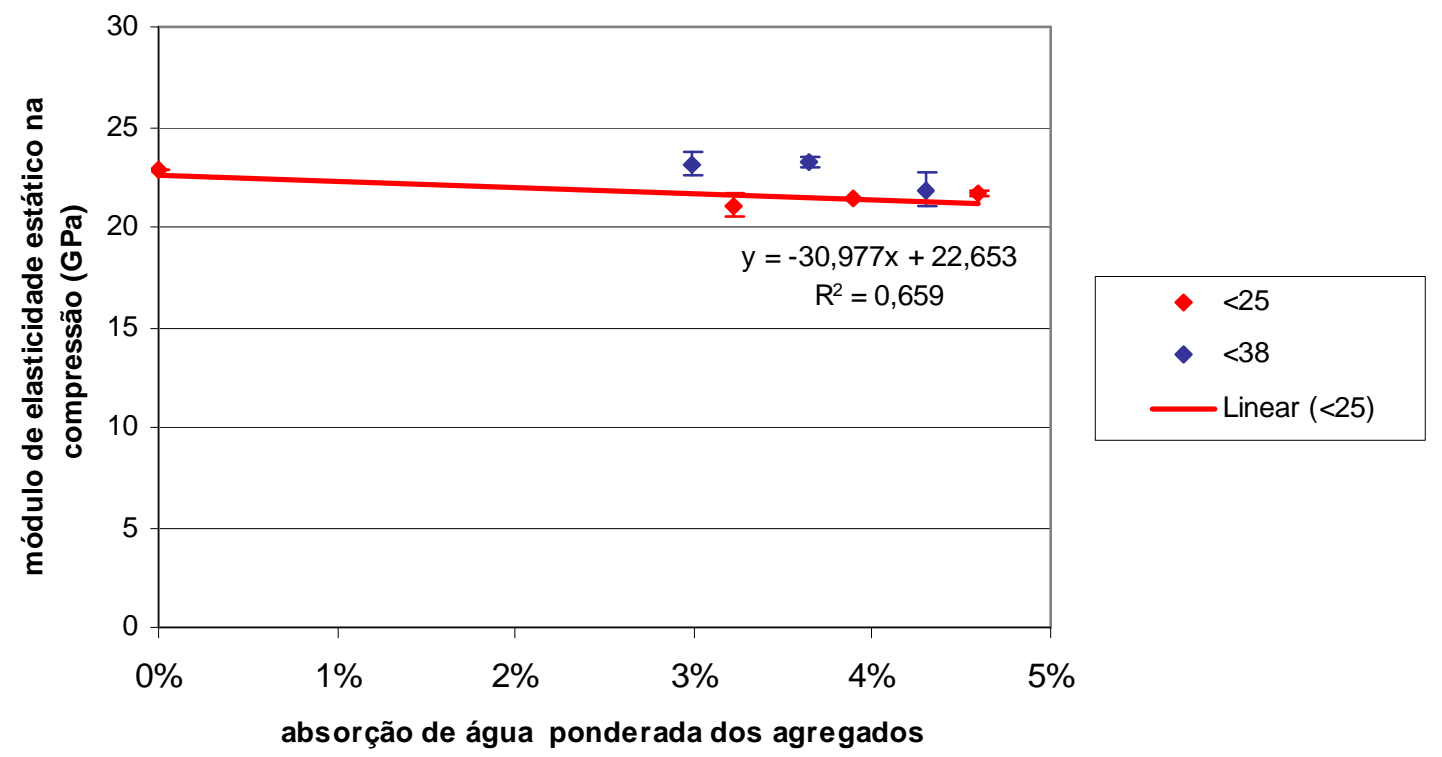

Figura 4.28 - Módulo de elasticidade à compressão aos 28 dias calculado a partir da curva tensão versus deformação em função da absorção ponderada dos agregados

Assim como os módulos de elasticidade encontrados nos ensaios anteriormente descritos, os módulos de elasticidade encontrados no ensaio à compressão apresentam queda com a substituição de agregados naturais por reciclados. Todavia, essa queda é menos acentuada se comparada àquela observada a partir de outros ensaios e os resultados apresentam menor variação, sendo, portanto, mais precisos. 


\section{Relação entre resistência à compressão e módulo de elasticidade estático em compressão}

Nas Figuras 4.29 e 4.30 são apresentadas relações entre o módulo de elasticidade estático na compressão e a resistência à compressão dos concretos contendo agregados reciclados do presente trabalho, contrastando-as com modelos de diferentes autores. Observa-se que os modelos variam, ficando a relação entre módulo de elasticidade e a resistência à compressão obtidos no presente estudo próximos àqueles calculados pelo modelo de Leite (2001) no caso da substituição de graúdos e miúdos, e abaixo dos valores calculados pelos modelos encontrados na literatura no caso da substituição somente da fração graúda. A variação pode ser fruto de diversos motivos, tais como a diferença na granulometria dos agregados utilizados, o método de mistura adotado, a qualidade dos agregados, o cimento utilizado, a inclusão ou não de aditivos no concreto, etc.

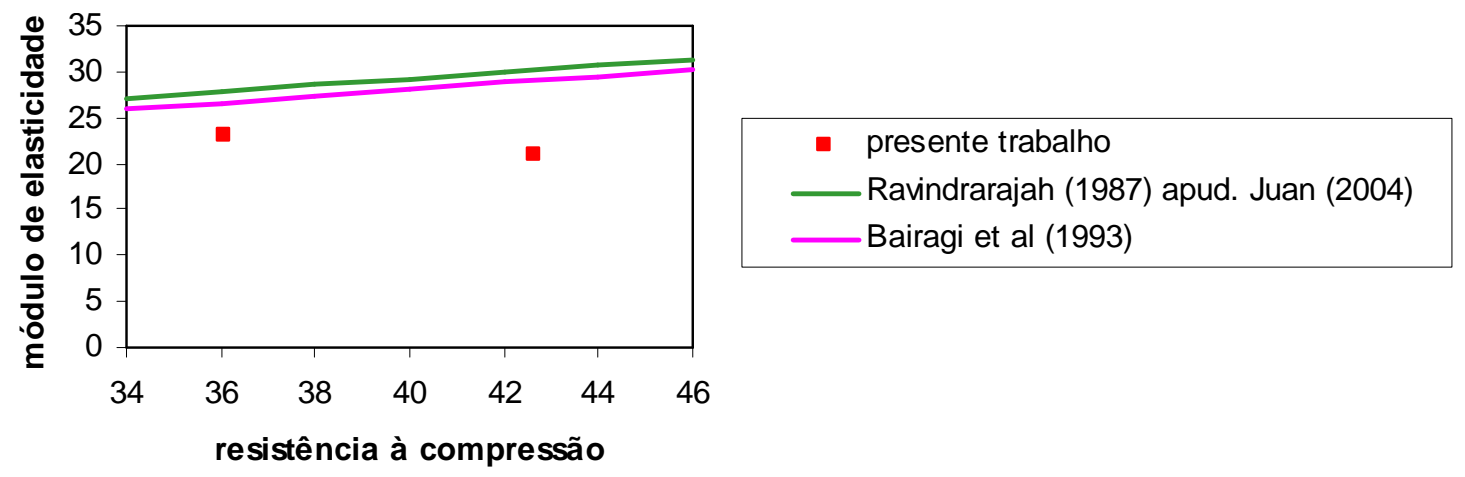

Figura 4.29 - módulo de elasticidade em função da resistência à compressão para concretos com incorporação de agregados graúdos reciclados
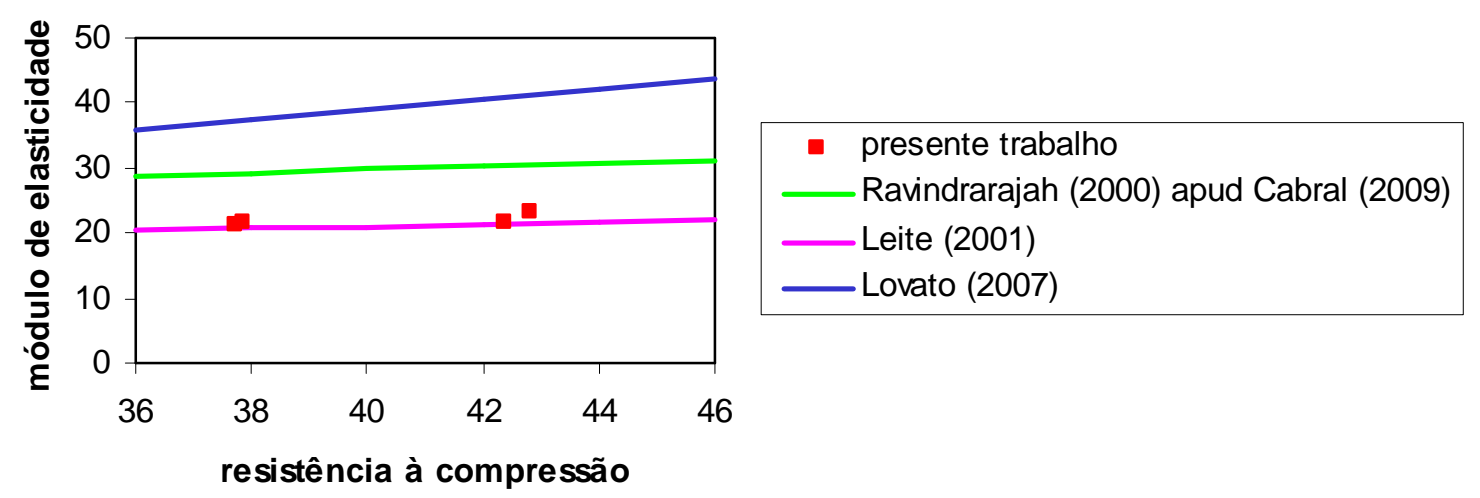

Figura 4.30 - módulo de elasticidade estático em função da resistência à compressão para concretos com incorporação de agregados graúdos e miúdos reciclados 


\subsubsection{Módulo de elasticidade dinâmico}

Os valores médios de módulo de elasticidade dinâmico encontrados, bem como seus desvios padrão e coeficientes de variação aos 7 e 28 dias, são apresentados nas Tabelas 4.15 e 4.16 e nas Figuras 4.31 e 4.32 .

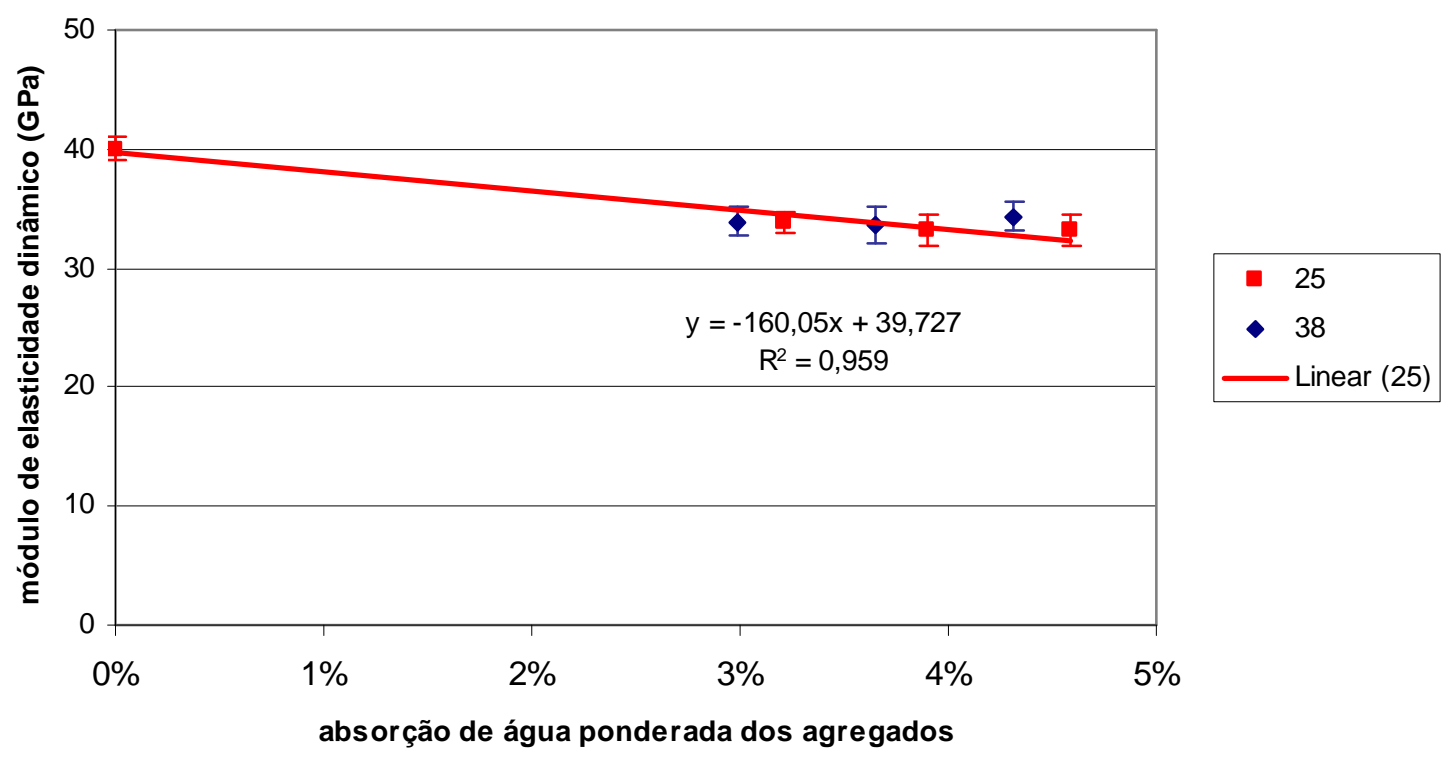

Figura 4.31 - Módulo de elasticidade dinâmico aos 7 dias

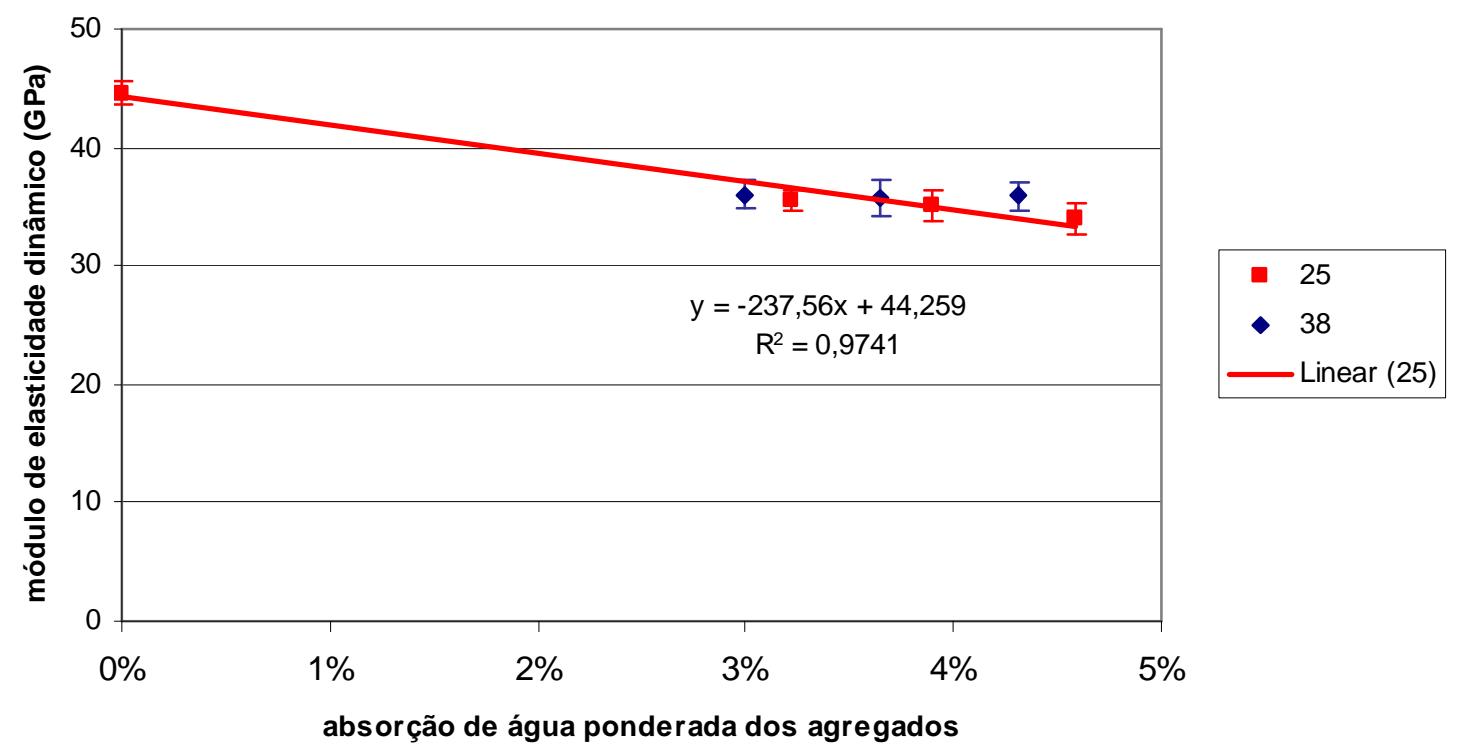

Figura 4.32 - Módulo de elasticidade dinâmico aos 28 dias 
Tabela 4.15 - Módulo de elasticidade dinâmico aos 7 dias

\begin{tabular}{|c|c|c|c|}
\cline { 2 - 4 } \multicolumn{1}{c|}{} & E dinâmico médio & Desvio padrão & Coeficiente de variação \\
\cline { 2 - 4 } \multicolumn{1}{c|}{} & (GPa) & (GPa) & (\%) \\
\hline C1 & 40,0 & 1,3 & 3,3 \\
\hline $4 / 25-F 1$ & 33,8 & 0,5 & 1,3 \\
\hline $4 / 25-F 2$ & 33,2 & 1,3 & 3,8 \\
\hline $4 / 25-F 3$ & 33,2 & 1,0 & 3,0 \\
\hline $4 / 38-F 1$ & 33,9 & 1,5 & 4,3 \\
\hline $4 / 38-F 2$ & 33,6 & 0,9 & 2,6 \\
\hline $4 / 38-F 3$ & 34,3 & 1,3 & 3,7 \\
\hline
\end{tabular}

Tabela 4.16 - Módulo de elasticidade dinâmico aos 28 dias

\begin{tabular}{|c|c|c|c|}
\cline { 2 - 4 } \multicolumn{1}{c|}{} & E dinâmico médio & Desvio padrão & Coeficiente de variação \\
\cline { 2 - 4 } \multicolumn{1}{c|}{} & $\mathbf{G P a})$ & $\mathbf{G P a})$ & $\mathbf{( \% )}$ \\
\hline $\mathrm{C} 1$ & 44,6 & 1,0 & 2,3 \\
\hline $4 / 25-\mathrm{F} 1$ & 35,5 & 0,9 & 2,5 \\
\hline $4 / 25-\mathrm{F} 2$ & 35,1 & 1,3 & 3,6 \\
\hline $4 / 25-\mathrm{F} 3$ & 34,1 & 1,2 & 3,6 \\
\hline $4 / 38-\mathrm{F} 1$ & 36,1 & 1,1 & 3,2 \\
\hline $4 / 38-\mathrm{F} 2$ & 35,7 & 1,5 & 4,3 \\
\hline $4 / 38-\mathrm{F3}$ & 35,9 & 1,2 & 3,4 \\
\hline
\end{tabular}

Os valores de módulo de elasticidade obtidos através do ultrassom para os concretos com agregados de dimensão máxima $25 \mathrm{~mm}$ revelam queda no módulo de elasticidade de $16 \%$ e de $20 \%$, para 7 e 28 dias respectivamente, ao se substituir os agregados graúdos naturais por reciclados. Ao se prosseguir com a substituição de agregados miúdos, nos teores de $25 \%$ e $50 \%$ os valores de módulo de elasticidade se apresentam muito próximos aos do concreto contendo somente agregados graúdos reciclados. A relação entre a absorção de água ponderada dos agregados e o módulo de elasticidade pode ser representada por retas com elevados coeficientes de correlação ( 0,959 aos 7 dias e 0,974 aos 28 dias). Os concretos contendo agregados de dimensão máxima $38 \mathrm{~mm}$ apresentam valores de módulo de elasticidade muito semelhantes aos concretos contendo agregados de dimensão máxima $25 \mathrm{~mm}$ com mesmo teor de substituição de agregados. 
4.2.5 Comparação entre os valores de módulo de elasticidade obtidos por diferentes métodos

Os valores de módulo de elasticidade encontrados das diferentes formas apresentadas são resumidos na Figura 4.33. O módulo de elasticidade dinâmico se apresenta substancialmente maior que o módulo de elasticidade estático. Segundo Neville (1982), o módulo dinâmico é aproximadamente igual ao módulo tangente inicial, portanto, maior que o módulo secante determinado no ensaio estático. Isso ocorre devido à heterogeneidade do concreto, que influencia os módulos estático e dinâmico de maneiras diferentes. Pode-se notar, também, que com exceção dos valores obtidos no ensaio de compressão diametral, a diferença entre os valores de módulo de elasticidade dinâmico e estático diminuem conforme se aumenta o teor de substituição dos agregados.

O valor de módulo de elasticidade obtido através da curva tensão versus deformação no ensaio de tração na flexão e aquele obtido através de analogia de Möhr no mesmo ensaio são razoavelmente próximos. O módulo de elasticidade obtido através da curva tensão versus deformação no ensaio de compressão, apesar de apresentar valores próximos aos obtidos no ensaio de tração na flexão, mostra-se menos sensível à variação da absorção de água ponderada dos agregados.

O módulo de elasticidade obtido no ensaio de tração na compressão diametral apresentou valores substancialmente inferiores aos apresentados em todos os outros ensaios, não sendo, desta maneira, devendo ser tomados como valores referenciais (provavelmente houve algum problema não detectado no momento da realização dos ensaios ou da instrumentação do corpo de prova). 


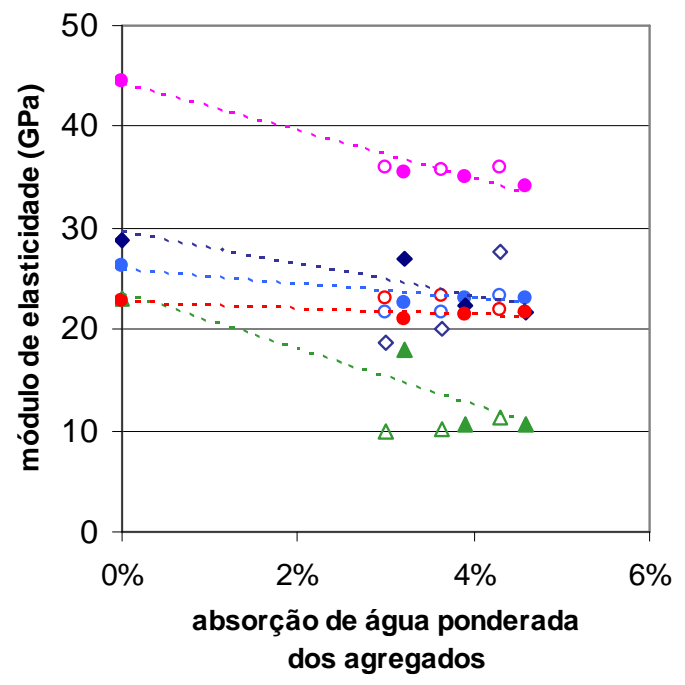

- 25 - dinâmico (ultrassom)

○ 38 - dinâmico (ultrassom)

- 25 - tração na flexão (analogia de Möhr)

○ 38 - tração na flexão (analogia de Möhr)

- 25 - tração na flexão (tensão x deformação)

$\diamond 38$ - tração na flexão (tensão x deformação)

$\triangle 25$ - tração na compressão diametral (tensão x deformação)

$\triangle 38$ - tração na compressão diametral (tensão x deformação)

- 25 - compressão (tensão x deformação)

○ 38 - compressão (tensão x deformação)

Figura 4.33 - módulo de elasticidade aos 28 dias em função da absorção de água ponderada dos agregados

\subsubsection{Modo de ruptura do concreto}

Ao se analisar o plano de ruptura dos concretos contendo agregados reciclados (Figura 4.34), nota-se que a ruptura se dá em todas as partes do concreto: na nova pasta de cimento, na antiga pasta de cimento e no agregado natural original, indicando que no caso do concreto contendo agregados reciclados a resistência não é determinada somente pela resistência da zona interfacial.
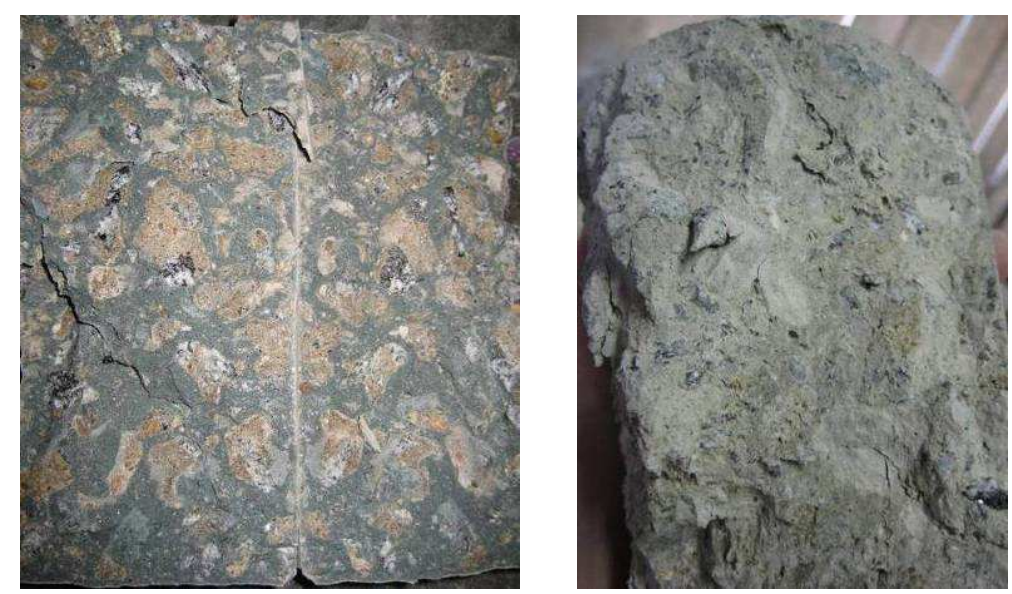

Figura 4.34 - Plano de ruptura dos corpos de prova de concreto contendo agregados reciclados

Nos corpos de prova extraídos das placas de concreto do pavimento, contudo, não foi observada a tendência de ruptura através dos agregados naturais com a mesma intensidade, podendo ser verificado que muitas vezes a ruptura se deu na zona de 
transição interfacial (Figura 4.35). Duas hipóteses podem explicar esse comportamento: a) agregados rochosos naturais presentes nos agregados reciclados foram enfraquecidos devido às etapas de britagem e/ou devido à secagem em estufa dos materiais antes da mistura; b) menor módulo de elasticidade apresentando pelos agregados reciclados leva a uma menor diferença dos valores de módulo do agregado e da pasta, resultando em uma melhor distribuição de tensões pelo concreto ${ }^{12}$.

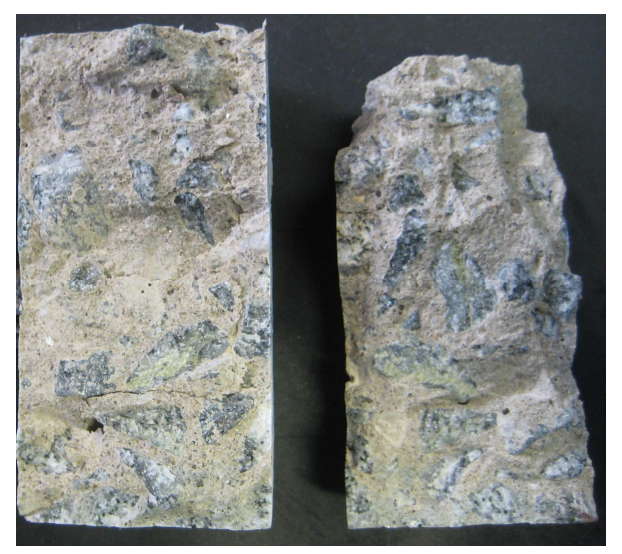

Figura 4.35- Plano de ruptura dos corpos de prova extraídos

Nos corpos de prova do concreto de controle é observado nitidamente que a ruptura ocorre preferencialmente na zona de transição interfacial (Figura 4.36). As explicações possíveis para tal são: a) o agregado natural, por apresentar absorção de água praticamente nula, favorece a formação de uma película de água ao seu redor, que age aumentando a relação a/c da pasta de cimento na zona interfacial; b) o agregado natural possui resistência superior àquela dos agregados reciclados, deixando de fazer parte do plano de ruptura do concreto já que a resistência do mesmo é determinada pelo elo mais fraco; c) o maior módulo de elasticidade do agregado natural leva à concentração de tensões em torno do agregado devido à diferença de módulos de elasticidade entre a pasta e o agregado.

\footnotetext{
${ }^{12}$ Existem autores que afirmam que a concentração de tensões em torno do agregado é provocada pela diferença de módulos de elasticidade (IBRACON, 2005).
} 

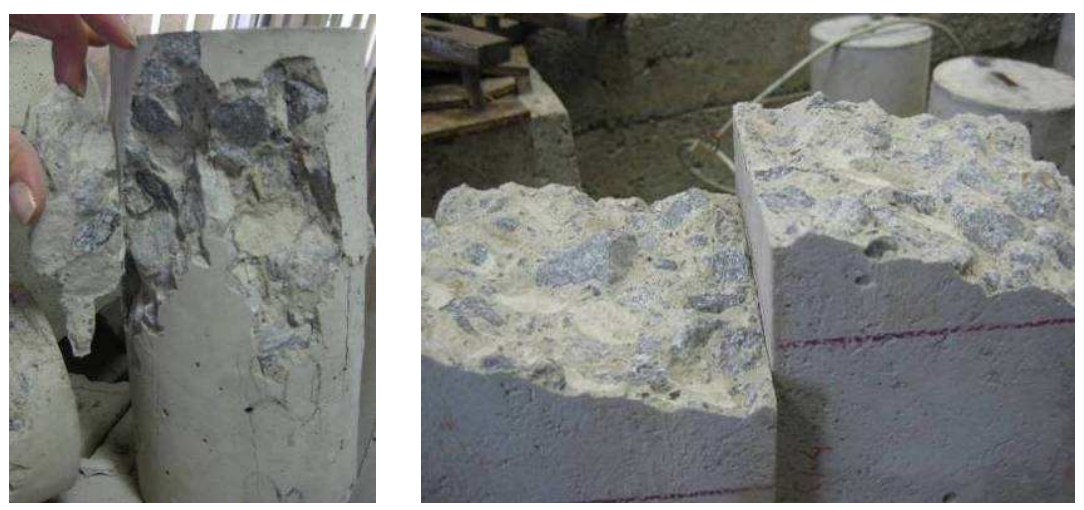

Figura 4.36 - Plano de ruptura dos corpos de prova do concreto convencional

\subsubsection{Relação entre resistência à tração na flexão e resistência à compressão}

$\mathrm{Na}$ Figura 4.37 são apresentadas as relações entre resistência à compressão e resistência à tração na flexão (aos 28 dias) em função da absorção de água ponderada dos agregados. Observa-se que a correlação linear obtida no caso dos concretos com agregados de dimensão máxima $25 \mathrm{~mm}$ possui alto coeficiente de correlação $\left(R^{2}=0,91\right)$. Com o uso de agregados de dimensões maiores a relação resistência à compressão/resistência à tração na flexão apresentou valores maiores. Portanto concluí-se que não é possível obter uma relação direta entre resistência à compressão e resistência à tração na flexão de concretos contendo agregados reciclados. É necessário se considerar outros fatores, tais como, por exemplo, a absorção e o tamanho máximo do agregado reciclado utilizado.

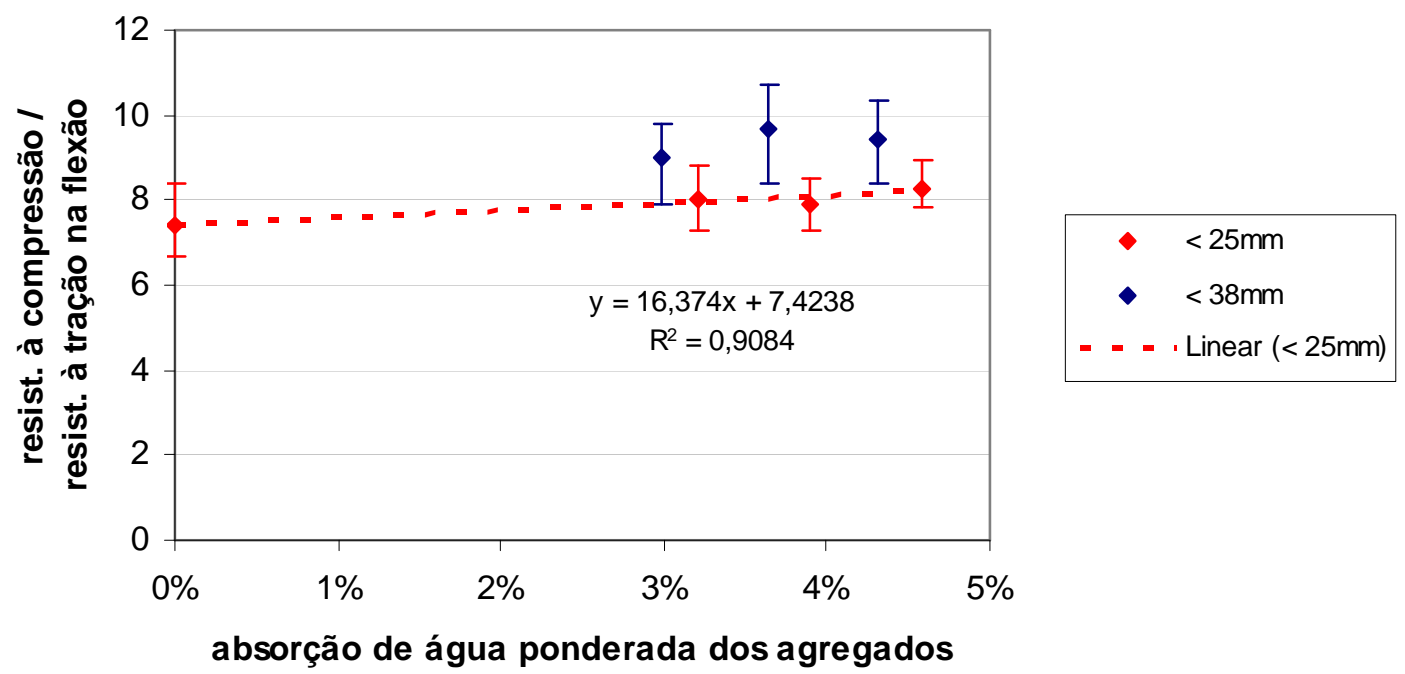

Figura 4.37 - Relação resistência à compressão e resistência à tração na flexão em função da absorção ponderada dos agregados 


\subsection{8 Índice de intensidade do ligante}

O índice intensidade do ligante (binder intensity index) é definido por Damineli et al. (2010) como sendo a quantidade de ligante necessária para se obter $1 \mathrm{MPa}$ de resistência mecânica - eq.(31). Quanto maior o valor da intensidade do ligante menor a eco eficiência do concreto, haja vista a maior necessidade de consumo de cimento para se obter uma unidade de resistência mecânica.

Os valores médios, máximos e mínimos de intensidade do ligante encontrados, para a resistência à tração na flexão e para a resistência à compressão, são apresentados nas Figuras 4.38 e 4.39. A intensidade do ligante relacionada à resistência à tração na compressão diametral não foi calculada, devido à grande dispersão de valores de resistência encontrados naquele ensaio.

$$
b i=\frac{b}{s}
$$

onde:

bi $\left(\mathrm{kg} \cdot \mathrm{m}^{-3} / \mathrm{MPa}\right)$ : intensidade do ligante

$\mathrm{b}\left(\mathrm{kg} \cdot \mathrm{m}^{-3}\right)$ :consumo total de material ligante

$\mathrm{s}(\mathrm{MPa})$ : resistência mecânica

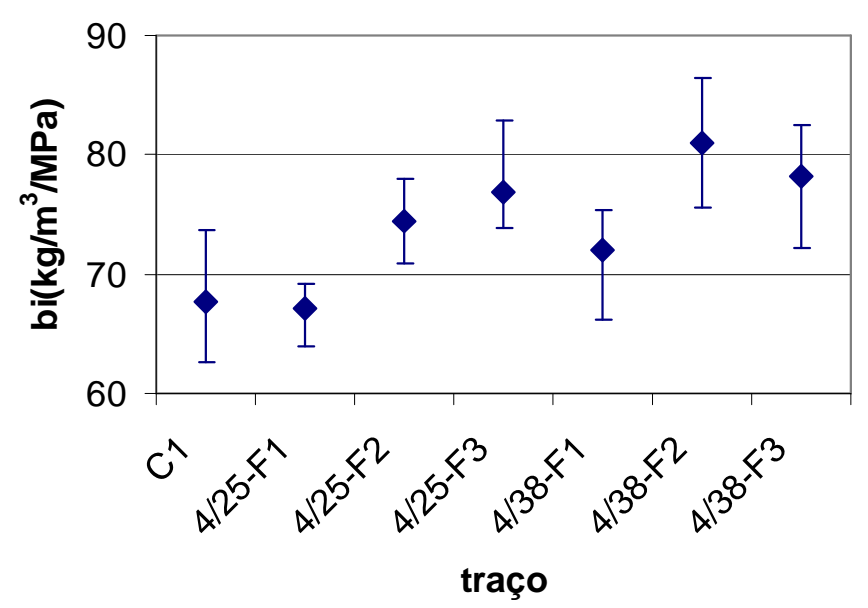

Figura 4.38 - índice de intensidade do ligante referente à resistência à tração do concreto aos 28 dias 


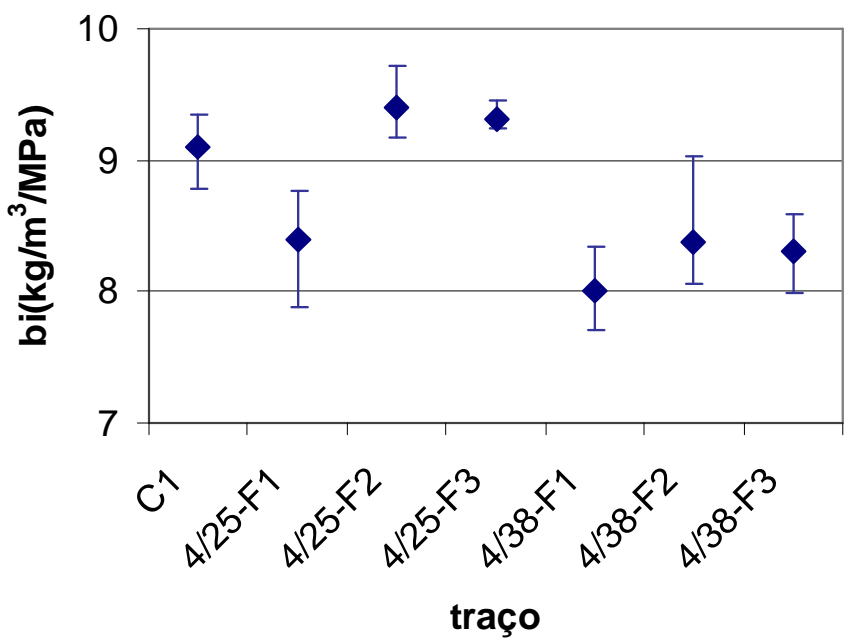

Figura 4.39 - índice de intensidade do ligante referente à resistência à compressão do concreto aos 28 dias

Excluindo-se o ponto correspondente ao índice de intensidade do ligante referente à resistência à compressão do concreto 4/25-F1, a tendência observada é de que os concretos contendo agregados reciclados com dimensão máxima do agregado semelhante àquela do concreto de controle, apresentem índices de intensidade do ligante semelhantes ou levemente mais elevados. Ou seja, o uso de agregados reciclados requer maior quantidade de cimento para que seja alcançada a resistência mecânica desejada. Contudo, apesar da menor eco eficiência no que diz respeito à intensidade do ligante, é possível que o ganho ambiental com a redução de distâncias de transporte de agregados seja suficiente para compensar a perda ambiental devida ao aumento no consumo de cimento.

No caso do concreto com agregados de dimensão máxima $38 \mathrm{~mm}$ os índices de intensidade do ligante referentes à resistência à tração na flexão se apresentaram muito próximos daqueles apresentados pelo concreto com agregados de dimensão máxima $25 \mathrm{~mm}$. No caso da intensidade do ligante referente à compressão, devido à alta resistência que apresentaram os concretos com agregados de dimensão máxima $38 \mathrm{~mm}$, os índices foram inferiores, ou seja, foi possível obter maiores resistências com menor consumo de cimento envolvido.

Comparando os resultados obtidos com aqueles de concretos convencionais encontrados na literatura brasileira (Figura 4.40), é possível concluir que mesmo 
com o uso de agregados reciclados é possível obter valores de intensidade de ligante semelhantes àqueles de concretos convencionais.

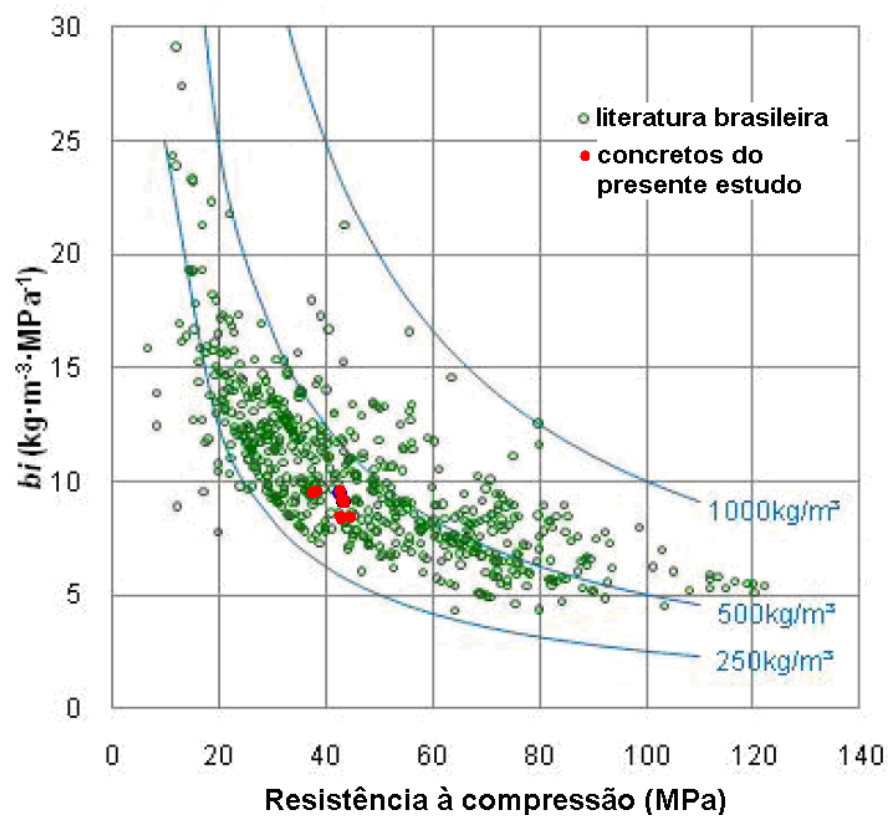

Figura 4.40 - Intensidade do ligante em função da resistência à compressão aos 28 dias a partir de dados retirados da literatura brasileira (adaptado de DAMINELI et al.,2010)

\subsubsection{Análise do concreto originário}

A extração de CP's a partir dos blocos retirados do Rodoanel foi realizada no Laboratório de Mecânica de Rochas (LMR) do Departamento de Engenharia de Minas e de Petróleo da EPUSP através de uma extratora de corpo de prova com serra copo diamantada da marca Hilti (Figura 4.41).
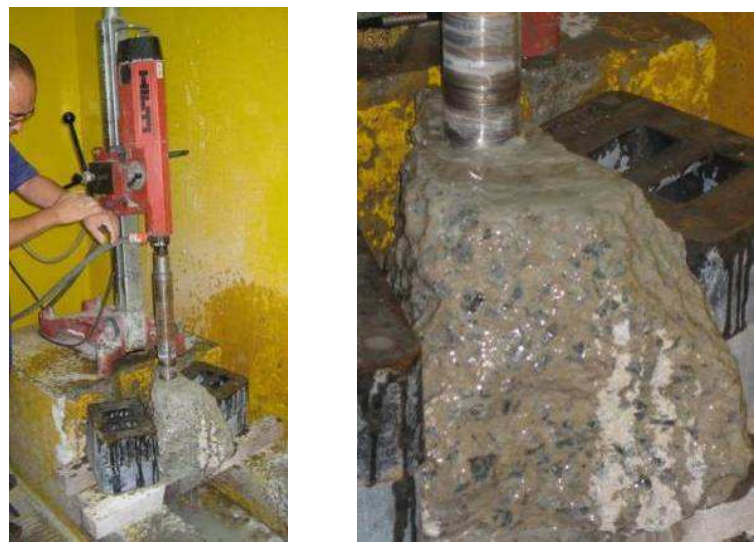

Figura 4.41 - Extração de corpos de prova a partir de blocos de concreto retirados do Rodoanel 
Os CP's foram extraídos com 5,4 cm de diâmetro $10 \mathrm{~cm}$ de altura. Essa dimensão reduzida foi escolhida devido à disponibilidade de equipamentos para extração dos CP's e à escassez de material disponível para extração dos CP's.

Valores de resistência à tração na compressão diametral concernentes ao concreto extraído do Rodoanel são apresentados na Tabela 4.17. Todavia, sabe-se que quanto maior o CP menor a resistência à tração na compressão apresentada, já que maior a quantidade de vazios presente no CP (ROCCO et al., 1999; IBRACON, 2005). Se utilizada a relação entre resistência à compressão de cilindros com diferentes diâmetros dada por Neville (1982), obtém-se um valor de resistência à tração na flexão de aproximadamente $4,9 \mathrm{MPa}$, ou seja, valor semelhante ao obtido no concreto de controle moldado $(4,7 \mathrm{MPa})$.

Tabela 4.17 - Resistência à tração na compressão diametral do concreto extraído do Rodoanel

\begin{tabular}{|c|c|c|c|}
\hline $\begin{array}{c}\text { Tensão de } \\
\text { ruptura à tração } \\
\text { indireta }\end{array}$ & $\begin{array}{l}\text { Tensão de } \\
\text { ruptura média }\end{array}$ & $\begin{array}{l}\text { Desvio } \\
\text { padrão }\end{array}$ & $\begin{array}{l}\text { Coef. de } \\
\text { variação }\end{array}$ \\
\hline (MPa) & (MPa) & (MPa) & (\%) \\
\hline 5,5 & \multirow{12}{*}{5,1} & \multirow{12}{*}{0,7} & \multirow{12}{*}{$14,3 \%$} \\
\hline 5,6 & & & \\
\hline 5,7 & & & \\
\hline 3,8 & & & \\
\hline 5,9 & & & \\
\hline 4,9 & & & \\
\hline 5,3 & & & \\
\hline 6,0 & & & \\
\hline 4,1 & & & \\
\hline 5,3 & & & \\
\hline 4,9 & & & \\
\hline 4,5 & & & \\
\hline
\end{tabular}

Os módulos de elasticidade dinâmicos encontrados são apresentados na Tabela 4.18. Nota-se que o valor de módulo de elasticidade encontrado é muito próximo àquele do concreto de referência aos 28 dias moldado para o estudo, o que indica que a pasta de cimento dos concretos moldados deve possuir características semelhantes à pasta de cimento do concreto originário. 
Tabela 4.18 - módulo de elasticidade dinâmico do concreto extraído do Rodoanel

\begin{tabular}{|c|c|c|c|}
\hline $\begin{array}{c}E \\
\text { dinâmico }\end{array}$ & $\begin{array}{c}\text { E } \\
\text { dinâmico } \\
\text { médio }\end{array}$ & $\begin{array}{l}\text { Desvio } \\
\text { padrão }\end{array}$ & $\begin{array}{l}\text { Coef. de } \\
\text { variação }\end{array}$ \\
\hline (GPa) & (GPa) & (GPa) & $(\%)$ \\
\hline 41,6 & \multirow{13}{*}{45,4} & \multirow{13}{*}{2,9} & \multirow{13}{*}{$6,5 \%$} \\
\hline 44,1 & & & \\
\hline 42,3 & & & \\
\hline 42,2 & & & \\
\hline 40,6 & & & \\
\hline 48,2 & & & \\
\hline 50,0 & & & \\
\hline 46,5 & & & \\
\hline 47,8 & & & \\
\hline 45,7 & & & \\
\hline 47,9 & & & \\
\hline 46,3 & & & \\
\hline 46,5 & & & \\
\hline
\end{tabular}




\section{CONCLUSÕES E RECOMENDAÇÕES}

A conservação de matérias primas naturais, a solução do problema de disposição de resíduos sólidos, a redução dos custos de construção e a economia de energia são razões que apontam a técnica de reciclagem de pavimentos de concreto como uma solução interessante para a reconstrução de antigas rodovias em concreto. Contudo, ao se considerar a possibilidade de utilização de agregados reciclados de concreto em substituição aos agregados naturais, deve-se considerar todos seus impactos ambientais e financeiros.

Recomenda-se que seja feito um estudo quantitativo de todas as vantagens e desvantagens, ambientais e econômicas, do emprego dessa solução para cada caso em que se considere utilizá-la, abrangendo os seguintes aspectos:

- consumo de energia (retirada de placas, britagem, transporte);

- emissão de $\mathrm{CO}_{2}$;

- emissão de radiação;

- preservação de recursos naturais;

- lixiviação;

- toxicidade;

- emissão de calor;

- emissão de ruído, poeira e vibrações;

- desempenho técnico da solução.

Ressalta-se que, como já comentou Bijen (1996), o uso de agregados reciclados não pode ser considerado puramente como reciclagem, pois neste caso, o concreto deveria ser processado de forma a se obter novamente agregados idênticos aos originais mais cimento.

O estudo comparativo entre agregados produzidos por britador de mandíbula e de impacto mostrou que as características apresentadas por estes são bastante 
semelhantes. As diferenças observadas não justificam o uso de britadores de impacto, que apesar de serem largamente recomendados na literatura, demandam maiores gastos de manutenção.

Em relação à viabilidade técnica do emprego do concreto em questão como matéria prima para a obtenção de um novo concreto, a grande maioria dos ensaios apresentou resultados satisfatórios, comprovando a viabilidade do emprego dessa solução. Algumas conclusões puderam ser fixadas:

- ensaios propostos por normas de caracterização de agregados naturais nem sempre são eficientes para análise de agregados reciclados, como é o caso da norma ABNT NBR 9776 (1987) para a determinação da massa específica aparente;

- no geral ocorre uma queda nos valores de resistência mecânica e de módulo de elasticidade do concreto conforme se aumenta a absorção de água ponderada dos agregados;

- o efeito da substituição de agregados naturais por reciclados na resistência à tração na flexão, na resistência à tração na compressão diametral, na resistência à compressão e no módulo de elasticidade do concreto pode ser representado razoavelmente por uma reta que correlaciona esses valores com a absorção de água ponderada dos agregados utilizados na mistura (somente um caso - concreto 4/25-F1 - de resistência à compressão não apresentou queda com a substituição dos agregados naturais por reciclados);

- a correlação entre a relação resistência à compressão e resistência à tração na flexão de concretos contendo agregados reciclados não é direta, devendo ser considerados fatores como a absorção ponderada dos agregados e a dimensão máxima dos mesmos.

Finalmente, em vista de todos os benefícios econômicos e ambientais advindos do uso da técnica de reciclagem e das incertezas que ainda existem quanto ao desempenho de pavimentos de concreto reciclados, torna-se indispensável a continuidade de estudos que possam analisar com mais exatidão quais são os fatores que influem no comportamento destes e como se devem evitar os problemas 
advindos do uso de agregados reciclados. Nesse trabalho foram estudados somente aspectos da resistência mecânica estática do concreto, algumas sugestões de temas de estudo para continuação desse projeto são:

- influência do material pulverulento nas características do concreto fresco;

- análise microscópica que possibilite uma interpretação do comportamento do concreto mais fundamentada;

- análise microscópica dos agregados produzidos por britador de mandíbula e por britador de impacto a fim de verificar a presença de possíveis defeitos gerados nas etapas de britagem;

- comportamento do concreto quanto à fratura;

- comportamento do concreto quanto à fadiga;

- comportamento do concreto quanto à retração (determinação do espaçamento entre juntas ideal);

- estudo das curvas de dosagem do concreto para cada teor de substituição dos agregados, verificando-se o consumo de cimento necessário para se obter a mesma resistência do concreto convencional;

- capacidade de transferência de cargas das placas de concreto do pavimento;

- cálculo de custos envolvidos no processo de reciclagem e reconstrução dos pavimentos;

- balanço do $\mathrm{CO}_{2}$ produzido com e sem a adoção da solução de reciclagem das placas de concreto;

- uso de plastificantes e cinza volante para melhorar o desempenho do concreto e custos ambientais e econômicos envolvidos;

- estudo da reologia do concreto reciclado (com uso de técnicas mais avançadas para avaliação da trabalhabilidade do concreto);

- beneficiamento dos agregados reciclados de concreto através de tratamento com altas pressões a fim de induzir a carbonatação na pasta de cimento aderida; 
- análise das tensões que ocorrem nas placas do pavimento através de programas que consideram teorias de sistemas de camadas elásticas a fim de verificar qual a mudança nas espessuras das camadas do pavimento necessárias ao se empregar agregados reciclados.

Face aos resultados obtidos na presente pesquisa, é recomendado que a reciclagem do concreto do Rodoanel Metropolitano Mário Covas seja considerada entre as possíveis e viáveis alternativas de manutenção para os problemas que se verificam em pista para as placas construídas em 2001/2002. 


\section{REFERÊNCIAS BIBLIOGRÁFICAS}

ACPA. Recycling concrete pavements. Skokie, USA: ACPA, 2009. 84p.

$\mathrm{ACl}$. Removal and reuse of hardened concrete: ACl 555R-01. Farmington Hills, USA: ACl, 2001. Disponível em:

$<$ http://www.bpesol.com/bachphuong/media/images/book/555r 01.pdf >. Acesso em: 1 fev. 2010.

ANDERSON, K. W.; UHLMEYER, J. S.; RUSSELL, M. Use of recycled concrete aggregate in PCCP: Literature Search - WSDOT research report. Olympia, USA: WSDOT, 2009. Disponível em:

$<$ http://www.wsdot.wa.gov/research/reports/fullreports/726.1.pdf >. Acesso em: 28 jan. 2010.

ANGULO, S. C. Caracterização de agregados de resíduos de construção e demolição reciclados e a influência de suas características no comportamento de concretos. 2005. 167p. Tese (Doutorado) - Escola Politécnica, Universidade de São Paulo, São Paulo, 2005.

ASSOCIAÇÃO BRASILEIRA DE NORMAS TÉCNICAS . NBR NM 30: agregado miúdo - determinação da absorção de água. Rio de Janeiro, 2001. 3p.

NBR NM 52: agregado miúdo - determinação de massa específica, massa específica aparente. Rio de Janeiro, 2002. 6p.

NBR NM 53: agregado graúdo - determinação de massa específica, massa específica aparente e absorção de água. Rio de Janeiro, 2003. 8p.

NBR NM 67: concreto - determinação da consistência pelo abatimento do tronco de cone. Rio de Janeiro, 1996. 8p.

NBR 5735: cimento portland de alto-forno. Rio de Janeiro, 1991. 5p.

NBR 5737: cimentos Portland resistentes a sulfatos. Rio de Janeiro, 1992. 4p.

NBR 5738: moldagem e cura de corpos-de-prova cilíndricos ou prismáticos de concreto. Rio de Janeiro, 1994. 9p. 
. NBR 5739: concreto - ensaio de compressão de corpos-de-prova cilíndricos. Rio de Janeiro, 1994. 4p.

NBR 7211: agregados para concreto. Rio de Janeiro, 1983. 5p.

NBR 7222: argamassa e concreto: determinação da resistência à tração por compressão diametral de corpos-de-prova. Rio de Janeiro, 1994. 3p.

. NBR 7389: agregados - apreciação petrográfica de materiais naturais para utilização como agregado em concreto. Rio de Janeiro, 1992. 6p.

. NBR 7583: execução de pavimentos de concreto simples por meio mecânico. Rio de Janeiro, 1986. 22p.

NBR 7809: agregado graúdo - determinação do índice de forma pelo método do paquímetro. Rio de Janeiro, 1983. 3p.

NBR 8522: concreto - determinação do módulo estático de elasticidade à compressão. Rio de Janeiro, 2008. 16p.

NBR 8802: concreto endurecido - determinação da velocidade de propagação de onda ultra-sônica. Rio de Janeiro, 1994. 8p.

NBR 9776: agregados: determinação da massa específica de agregados miúdos por meio do frasco Chapman. Rio de Janeiro, 1987. 3p.

NBR 9833: concreto fresco - determinação da massa específica e do teor de ar pelo método gravimétrico. Rio de Janeiro, 1987. 6p.

NBR MB 3483: concreto - determinação da resistência à tração na flexão em corpos-de-prova prismáticos. Rio de Janeiro, 1991. 3p.

BAIRAGI, N.K.; RAVANDE, K.; PAREEK, V.K. Behaviour of concrete with different proportions of natural and recycled aggregates. Resources, Conservation and Recycling, v. 9, n. 1-2, p. 109-126, Aug. 1993.

BALBO, J. T. Pavimentação asfáltica: materiais, projeto e restauração. São Paulo: Oficina de Textos, 2007. 560p. 
Pavimentos de concreto. São Paulo: Oficina de Textos, 2009. 472p.

BALBO, J. T. et al. Sobre as dimensões de amostras para ensaios de tração na flexão para controle tecnológico de pavimentos de concreto de cimento Portland. In: REUNIÃO ANUAL DE PAVIMENTAÇÃO, 12., 2003, Aracajú. Anais. 2003. CDROM.

BARRA, M. Dosagem de concretos com agregados reciclados: aspectos particulares. In: RECICLAGEM NA CONSTRUÇÃO CIVIL, ALTERNATIVA ECONÔMICA PARA PROTEÇÃO AMBIENTAL, 1997, São Paulo. Anais. São Paulo: PCC-USP, 1997, p. 39-43.

BIJEN, J. Waste materials and alternative products: pro's and con's. In: CONCRETE FOR EVIRONMENT ENHANCEMENT AND PROTECTION, 1996, Dundee, UK. Concrete in the service of mankind: concrete for environment enhancement and protection. Londres: E\&FN Spon, 1996. p. 587-598.

BREMNER, T. W.; HOLM, T. A. Elastic compatibility and the behavior of concrete. ACI Journal, vol. 83, n. 2, p. 244-250, March/Apr. 1986.

BUTTLER, A. M.; MACHADO JR., E. F. Properties of concrete with recycled concrete coarse aggregates. In: INTERNATIONAL ACI/CAMET CONFERENCE, 4., 2005, Olinda. Proceedings. Michigan: ACI, 2005. p. 496-510.

CABRAL, A. E. B. et al. Mechanical properties modeling of recycled aggregate concrete. Construction and Building Materials, v. 24, n. 4, p. 421-430, Apr. 2009.

CARRIJO, P. M. Análise da influência da massa específica de agregados graúdos provenientes de resíduos de construção e demolição no desempenho mecânico do concreto. 2005. 129p. Dissertação (Mestrado) - Escola Politécnica, Universidade de São Paulo, São Paulo, 2005.

CERVANTES, V.; ROESLER, J. The use of recycled concrete aggregate for rigid pavements, 2006. Disponível em:

$<$ http://www.ceat.uiuc.edu/PUBLICATIONS/brownbag/presentations/Aug\%2006\%20 Roesler\%200MP\%20Recycled\%20Concrete.pdf> Acesso em: 3 jul. 2010. properties of concrete containing recycled concrete aggregate. Urbana, USA: Center of Excellence for Airport Technology, 2007. (Technical note, v. 34) 
CERVO, T. C. Estudo da resistência à fadiga de concretos de cimento Portland para pavimentação. 2004. 220p. Tese (Doutorado) - Escola Politécnica, Universidade de São Paulo, São Paulo, 2004.

CHAVES, A. P. et al. Tecnologia mineral e suas aplicações na reciclagem de resíduos de construção e demolição. Rio de Janeiro: Centro de Tecnbologia Mineral - Ministério da Ciência e da Tecnologia, 2006. Disponível em: <http://www.cetem.gov.br/publicacao/CTs/CT2006-072-00.pdf >. Acesso em: 9 de jul. 2010.

CHAVES, A. P.; PERES, A. E. C. Teoria e prática do tratamento de minérios: britagem, peneiramento e moagem. São Paulo: Signus, 1999. 662p., v.3.

$\mathrm{CHI}$, J. M. et al. Effect of aggregate properties on the strength and stiffness of lightweight concrete. Cement \& Concrete Composites, v. 25, n.2, p. 197-205, Feb. 2003.

CMRA. Case histories. CMRA, 2008. Disponível em:

< http://www.concreterecycling.org/histories.html>. Acesso em: 28 jan. 2010.

CONFEDERAÇÃO NACIONAL DO TRANSPORTE. Pesquisa CNT/SEST/SENAT. 2007. Disponível em:

<www.cnt.org.br/>. Acesso em: 25 de jul. 2009.

CORINALDESI, V.; MORICONI, G. Influence of mineral additions on the performance of $100 \%$ recycled aggregate concrete. Construction and Building Materials, v. 23, n. 8, p. 2869-2876, Aug. 2009.

CUTTELL, G. D. et al. Performance of rigid pavements containing recycled concrete aggregates. Transport Research Record, v. 1574, n. 971071, 1997.

DAMINELI, B. L. Estudo de métodos para caracterização de propriedades físicas de agregados graúdos de resíduos de construção e demolição reciclados. 2007. 107p. Dissertação (Mestrado) - Escola Politécnica, Universidade de São Paulo, São Paulo, 2007.

DAMINELI, B., L. et al. Measuring the eco-efficiency of cement use. Escola Politécnica, Universidade de São Paulo: 2010. /No prelo/ 
DARTER, M. I. Initial evaluation of Michigan JRCP crack deterioration. Lansing, USA: Michigan Concrete Paving Association, Dec. 1988.

DEPARTAMENTO NACIONAL DE ESTRADAS DE RODAGEM. DNER-ME 035: agregados - determinação da abrasão "Los Angeles". Rio de Janeiro, 1998. 6p.

DNER-ME 084: agregado miúdo - determinação da densidade real. Rio de Janeiro, 1995. 3p.

DE VRIES, P. Concrete recycled: crushed concrete aggregate. In: CONCRETE FOR EVIRONMENT ENHANCEMENT AND PROTECTION, 1996, Dundee, UK.

Proceedings. Londres: E\&FN Spon, 1996, p. 121-130.

DI NIRO, G.; DOLARA, E., RIDGWAY, P. Recycled aggregate concrete (RAC): properties of aggregate and RC beams made from RAC. In: CONCRETE FOR EVIRONMENT ENHANCEMENT AND PROTECTION, 1996, Dundee, UK.

Proceedings. Londres: E\&FN Spon, 1996, p. 141-149.

DOMINGO-CABO, A. et al. Creep and shrinkage of recycled aggregate concrete. Construction and Building Materials, v. 23, n. 7, p. 2545-2553, July 2009.

ECCO. Recycling concrete and masonry. EV.22. Skokie, USA: ECCO, 1999. Disponível em: <http://www.p2pays.org/ref/14/13608.pdf >. Acesso em: 1 fev. 2010.

Recycling Concrete Saves Resources, Eliminates Dumping. EV15. Skokie, USA: Environmental Council of Concrete Organizations, 1997. Disponível em:

< http://www.p2pays.org/ref/14/13602.pdf >. Acesso em: 28 jan. 2010.

EICKSCHEN, E.; SIEBEL, E. Reconstruction of concrete roads using recycled sand as aggregate. In: INTERNATIONAL SYMPOSIUM ON CONCRETE ROADS, 8., 1998, Lisbon. Proceedings. Lisbon: AIPCR-PIARC, CEMBUREAU, ATIC, Sept. 1998, p. 121-126.

EPA. Industrial materials recycling Tools \& Resources. 2 ed. Washington, D.C.: Environmental Protection Agency, 2009. Disponível em: $<$ http://www.epa.gov/osw/conserve/rrr/imr/pdfs/tools1-09.pdf>. Acesso em: 28 jan. 2010. 
ETXEBERRIA, M.; VÁZQUEZ, E.; MARÍ, A. Microstructure analysis of hardened recycled aggregate concrete. Magazine of Concrete Research, v. 58, n. 10, p. 683690, Dec. 2006.

ETXEBERRIA, M. et al. Influence of amount of recycled coarse aggregates and production process on properties of recycled aggregate concrete. Cement and Concrete Research, v. 37, n. 5, p. 735-742, May 2007.

EVANGELISTA, L.; BRITO, J. Carbonation and chloride penetration in concrete made with fine recycled concrete aggregates. In: SIMPÓSIO ÍBERO-AMERICANO SOBRE "CONCRETO ESTRUTURAL", 2., 2006, Rio de Janeiro. Anais. Rio de Janeiro: Ibracon, set. 2006. CD-ROM.

Mechanical behaviour of concrete made with fine recycled concrete aggregates. Cement \& Concrete Composites, v. 29, n. 5, p. 397-401, May 2007.

. Durability performance of concrete made with fine recycled concrete aggregates. Cement \& Concrete Composites, v. 32, n. 1, p. 9-14, Jan. 2009.

FHWA. Guidelines for the use of lithium to mitigate or prevent alkali-silica reaction (ASR). FHWA-RD-03-047. Georgetown Pike, USA: U.S. Departement of Trasnportation Federal Highway Administration, 2003. Disponível em: <http://www.tfhrc.gov/pavement/pccp/pubs/03047/index.htm\#toc >. Acesso em: 11 jun. 2010.

FLEISCHER, W. Concrete for heavily loaded modern traffic areas (part 1 and 2). Beton, v. 11, p. 536-597, 2003.

Construction of modern pavements. In: CONCRETE FOR EVIRONMENT ENHANCEMENT AND PROTECTION, 1996, Dundee, UK. Concrete in the service of mankind: concrete for environment enhancement and protection. Londres: E\&FN Spon, 1996.

FONSECA, N. M. S. Betões estruturais com a incorporação de agregados grossos reciclados de betão: Influência das condições de cura no desempenho mecânico. 2009. 153p. Dissertação (Mestrado) - Instituto Superior Técnico, Universidade Técnica de Lisboa, Lisboa, 2009. 
GRESS, D. L.; SNYDER, M. B.; STURTEVANT, J. R. Performance of rigid pavements containing recycled concrete aggregates - 2006 update. Transport Research Record, v. 2113, p. 99-107, May 2009.

GÓMEZ-SOBERÓN, J. M. V. Porosity of recycled concrete with substitution of recycled concrete aggregate: an experimental study. Cement and Concrete Research, v. 32, n. 8, p. 1301-1311, Aug. 2002.

GONÇALVES, J. P. et al. Absortividade de concretos contendo agregados reciclados. In: CONGRESSO BRASILEIRO DO CONCRETO, 49., 2007, Bento Gonçalves. Anais. São Paulo: Ibracon, 2007. CD-ROM.

GONÇALVES, P. C. M. Betão com agregados reciclados - Análise comentada da legislação existente. 2007. 132p. Dissertação (Mestrado) - Instituto Superior Técnico, Universidade Técnica de Lisboa, Lisboa, 2007.

GONÇALVES, R. D. C.; MACHADO JR, E. F. Agregado reciclado de resíduos de concreto - um novo material para dosagens estruturais. In: CONGRESSO BRASILEIRO DO CONCRETO, 43., 2001, Foz do Iguaçu. Anais. São Paulo: Ibracon, 2001. CD-ROM.

GONZÁLEZ-FONTEBOA, B. et al. Investigación sobre hormigones com árido reciclado. Estúdios sobre material y propriedades básicas. In: CONGRESSO BRASILEIRO DO CONCRETO, 43., 2001, Foz do Iguaçu. Anais. São Paulo: lbracon, 2001. CD-ROM.

HAIDER, M.; VON FAHRBAHNOBERFLÄCHEN, L. Concrete pavements today and tomorrow. Austrian conference on concrete roads, Betonstraßen, Vienna: 2007.

HALL, K. Long-life concrete pavements in Europe and Canada. Publication No. FHWA-PL-07-027. Washington D.C.: Federal Highway Administration, 2007.

HANSEN, T. C. Recycling of demolished concrete and masonry : report of Technical Committee 37-DRC, Demolition and reuse of concrete. RILEM report 6. London; New York: E \& FN Spon, 1992.

HANSEN, T. C.; NARUD, H. Strength of recycled concrete made from crushed concrete coarse aggregate. Concrete International, v.5, n.1, p. 79-83, Jan. 1983. 
HELENE, P. R. L.; TERZIAN, P. Manual de dosagem e controle do concreto. São Paulo: Pini, 1992. 349p.

HENDRICKS, C.F. Recycling and reuse as a basis for sustainable development in construction industry. In: CONCRETE FOR EVIRONMENT ENHANCEMENT AND PROTECTION, 1996, Dundee, UK. Concrete in the service of mankind: concrete for environment enhancement and protection. Londres: E\&FN Spon, 1996.

IBRACON. Concreto: ensino, pesquisa e realizações. São Paulo: Ibracon, v.1, 2005. 792p.

IPRF. Evaluation, design and construction techniques for airfield concrete pavement used as recycled material for base. Skokie, USA: Innovative Pavement Research Foundation, 2006. (Research Report, v. IPRF-01-G-002-03-5)

JOHN, D. A. S.; POOLE, A. W.; SIMS, I. Concrete petrography: a handbook of investigative techniques. Elsevier, 1998. 474p.

JUAN, M. S. Estudio sobre la utilización de árido reciclado para la fabricación de hormigón estructural. 2004. 502p. Tesis (Doctorado) - Escuela Técnica Superior de Ingenieros de Caminos, Canales y Puertos, Universidad Politécnica de Madrid, Madrid, 2004.

JUAN, M. S.; GUTIÉRREZ, P. A. Influence of recycled aggregate quality on concrete properties. In: INTERNATIONAL RILEM CONFERENCE ON THE USE OF RECYCLED MATERIALS IN BUILDINGS AND STRUCTURES, 2004, Barcelona. Proceedings. Bagneux, FR: RILEM publications, 2004, p. 545-553.

Study on the influence of attached mortar content on the properties of recycled concrete aggregate. Construction and Building Materials, v. 23, n. 2, p. 872-877, Feb. 2009.

KHATIB, K. Properties of concrete incorporating fine recycled aggregate. Cement and Concrete Research, v. 35, n. 4, p. 763-769, Apr. 2005.

KLEMT, K. Bearing and deformation performance of concrete with recycled aggregates. Darmstadt Concrete, 1997. Disponível em:

$<$ http://www.b-im.de/public/AddFrame.asp?url left=/Doku Inhalt.htm\&url main=/Public/TUDMassiv/ DaCon97Klemt.htm> Acesso em: 9 de jul. 2008. 
KOMLOS, K. et al. Ultrasonic pulse velocity test of concrete properties as specified in various standards. Cement and Concrete Composites, v. 18, n. 5, p. 357-364, 1996.

KOU, S. C.; POON, C. S. Mechanical properties of 5-year-old concrete prepared with recycled aggregates obtained from three different sources. Magazine of Concrete Research, v. 60, n. 1, p. 57-64, Feb. 2008.

KOU, S. C.; POON, C. S.; CHAN, D. Influence of fly ash as cement replacement on the properties of recycled aggregate concrete. Journal of Materials in Civil Engineering ASCE, v. 19, n. 19, p. 709-717, Sept. 2007.

Influence of fly ash as cement addition on the hardened properties of recycled aggregate concrete. Materials and Structures, v. 41, n. 7, p. 1191-1201, 2008.

KOBAYASHI, R.; HAMADA, S. Bending fatigue properties of concrete pavement mixed with recycled aggregate. In: CONGRESSO BRASILEIRO DO CONCRETO, 49., 2007, Bento Gonçalves. Anais. São Paulo: Ibracon, 2007.

KRENN, H. E STINGLHAMMER, H. Aus alt mach neu: betondeckenerstellung in recyclingbauweise. In: INTERNATIONAL SYMPOSIUM ON CONCRETE ROADS, 7., 1994, Vienna. Proceedings. Vienna: AIPCR-PIARC, 1994.

LABORATÓRIO NACIONAL DE ENGENHARIA CIVIL. LNEC E391: determinação da resistência à carbonatação. Lisboa, 1993.

LEITE, M; B. Avaliação de propriedades mecânicas de concretos produzidos em agregados reciclados de resíduos de construção e demolição. 2001. 270p. Tese (Doutorado) - Escola de Engenharia, Universidade Federal do Rio Grande do Sul. Porto Alegre, 2001.

LEVY, S. M. Contribuição ao estudo da durabilidade de concretos, produzidos com resíduos de concreto e alvenaria. 2001. 194p. Tese (Doutorado) - Escola Politécnica, Universidade de São Paulo, São Paulo, 2001.

LEVY, S. M.; HELENE, P. R. L. Influência dos agregados reciclados no módulo de elasticidade de concretos com agregados convencionais e agregados reciclados da teoria à prática. In: CONGRESSO BRASILEIRO DO CONCRETO, 43., 2001, Foz do Iguaçu. Anais. São Paulo: Ibracon, 2001. CD-ROM. 
LI, J., XIAO, H., ZHOU, Y. Influence of coating recycled aggregate surface with pozzolanic powder on properties of recycled aggregate concrete. Construction and Building Materials, v. 23, n. 3, p. 1287-1291, March 2009.

LIMA, P. R. L. et al. Influência do agregado miúdo reciclado sobre a resistência mecânica do concreto. In: CONGRESSO BRASILEIRO DO CONCRETO, 49., 2007, Bento Gonçalves. Anais. São Paulo: Ibracon, 2007. CD-ROM.

LIMBACHIYA, M. C.; LEELAWAT, T.; DHIR, R. K. Use of recycled concrete aggregate in high-strength concrete. Materials and Structures, v.33, n. 9, p. 574580, Nov. 2000.

LÓPEZ-GAYARRE, F. et al. Influence of recycled aggregate quality and proportioning criteria on recycled concrete properties. Waste Management, v. 29, n. 12, p. 3022-3028, 2009.

LOVATO, P. S. Verificação dos parâmetros de controle de agregados reciclados de resíduos de construção e demolição para utilização em concreto. 2007. 180p. Dissertação (Mestrado) - Escola de Engenharia, Universidade Federal do Rio Grande do Sul. Porto Alegre, 2007.

MEHTA, P. K. Concrete: structure, properties and materials. New Jersey: PrenticeHall, Inc., 1986. 450p. (Prentice-Hall international series in civil engineering and engineering mechanics).

MEHTA, P. K.; MONTEIRO, P. J. M. Concreto: microestrutura, propriedades e materiais. $3^{\underline{a}}$ ed. São Paulo: Ibracon, 2008. 674p.

MOMBER, A. W. The fragmentation of cementitious composites in a jaw breaker. Theoretical and applied fracture mechanics, v. 38, n. 2, p. 151-164, 2002.

NAGATAKI, S. et al. Assessment of recycling process induced damage sensitivity of recycled concrete aggregates. Cement and Concrete Research, v. 34, n. 6, p. 965971, June 2004.

NEALEN, A.; RUHL, M. Strength of recycled concrete made from crushed concrete coarse aggregate. Darmstadt Concrete, v. 12, 1997. Disponível em:

$<$ http://www.b-i-

m.de/public/AddFrame.asp?url left=/Doku Inhalt.htm\&url main=/Public/TUDMassiv/ dacon97nealen.htm >. Acesso em: 9 abr. 2010. 
NEALEN, A; SCHENK, S. The influence of recycled aggregate core moisture on freshly mixed and hardened concrete properties. Darmstadt Concrete, v. 13, 1998. Disponível em:

$<$ http://www.b-i-m.de/public/tudmassiv/dacon13nealenschenk.htm >. Acesso em: 21 abr. 2010.

NEVILLE, A. M. Propriedades do concreto. 3 ed. São Paulo: Pini, 1982. 738p.

OLIVEIRA, M. J. E.; ASSIS, C. S. Estudo de resíduo de concreto para reciclagem. In: CONGRESSO BRASILEIRO DO CONCRETO, 43., 2001, Foz do Iguaçu. Anais. São Paulo: Ibracon, 2001. CD-ROM.

POON, C. S. et al. Influence of moisture states of natural and recycled aggregates on the slump and compressive strength of concrete. Cement and Concrete Research, v. 34, n. 1, p. 31-36, Jan. 2004a.

POON, C. S.; KOU, S. C.; LAM, L. Inlfuence of recycled aggregate on slump and bleeding of fresh concrete. Materials and Structures, v. 40, n. 9, p. 981-988, Nov. 2007.

POON, C. S.; SHUI, Z. H.; LAM. Effect of microstructure of ITZ on compressive strength of concrete prepared with recycled aggregates. Construction and Building Materials, v. 18, n. 6, p. 461-468, July 2004b.

QUARCIONI, V. A. Reconstituição de traço de argamassas: atualização do método IPT. 1998; 188p. Dissertação (Mestrado) - Escola Politécnica, Universidade de São Paulo. São Paulo, 1998.

RAHAL, K. Mechanical properties of concrete with recycled coarse aggregate. Building and Environment, v. 42, p. 407-415, 2007.

RAVINDRARAJAH, R. S.; TAM, C.T. Recycling concrete as fine aggregate in concrete. The International Journal of Cement Composites and Lightweight Concrete, v. 9, n. 4, p. 235-241, Nov. 1987.

RICCI, G. Estudo de características mecânicas do concreto compactado com rolo com agregados reciclados de construção e de demolição para pavimentação.2007; 196p. Dissertação (Mestrado) - Escola Politécnica, Universidade de São Paulo. São Paulo, 2007. 
RICCI, G. E BALBO, J.T. Estudo de resistências e módulo de elasticidade do concreto compactado com rolo com agregados reciclados de construção e de demolição para pavimentação. In: CONGRESSO BRASILEIRO DO CONCRETO, 50., 2008, Salvador. Anais. São Paulo: Ibracon, 2008. CD-ROM.

ROCCO, C. et al. Size effect and boundary conditions in the brazilian test: experimental verification. Materials and Structures, v. 32, n. 3, p. 210-217, Apr. 1999.

ROESLER, J.; SALAS, A. Properties of recycled aggregate concrete, technical note43 for O'Hare modernization program. University of Illinois, 2009.

RUHL, M. Water absorption capacity of recycled demolition rubbish. Darmstadt Concrete, v. 97, 1992. Disponível em:

$<$ http://www.b-i-m.de/public/AddFrame.asp?url left=/Doku Inhalt.htm\&url main=/ Public/TUDMassiv/dacon97ruehl.htm>. Acesso em: 7 abr. 2010.

SAKAI, M. Fracture mechanics of refractory materials. Taikabutsu Overseas, v. 8 , n. 2, p. 4-12, June 1987.

SALEM, R. M.; BURDETTE, E. G. Role of chemical and mineral admixtures on physical properties and frost-resistance of recycled aggregate concrete. ACI Materials Journal, v. 95, n. 5, p. 558-563, Sept./Oct., 1998.

SANI, D. et al. Leaching and mechanical behaviour of concrete manufactured with recycled aggregates. Waste Management, v. 25, n. 2, p. 177-182, 2005.

SANTOS, J. R.; BRANCO, F.; BRITO, J. Mechanical properties of concrete with coarse recycled aggregates. Structural Engineering International, v. 14, n. 3, p. 213-215, Aug. 2004.

SHAYAN, A.; XU, A. Performance and properties of structural concrete made with recycled concrete aggregate. ACI Materials Journal, v. 100, n. 5, p. 371-380, Sept. 2003.

SHIMA, H. et al. An advanced concrete recycling technology and its applicability assessment through input-output analysis. Journal of Advanced Concrete Technology, v. 3, n. 1, p. 53-67, Feb. 2005. 
SILVA, E. F.; SILVA, A. C. N. C.; CANÊDO, V. S. Concreto fabricado com agregado miúdo proveniente da reciclagem do entulho de concreto. In: CONGRESSO BRASILEIRO DO CONCRETO, 43., 2001, Foz do Iguaçu. Anais. São Paulo: Ibracon, 2001. CD-ROM.

SMITH, J. T. et al. Coarse recycled aggregate concrete pavements - design, instrumentation, and performance. 2008. Disponível em:

$<$ http://www.tac-

atc.ca/english/resourcecentre/readingroom/conference/conf2008/docs/f1/Smith.pdf>. Acesso em: 22 jul. 2010.

SNYDER, M. B. et al. Physical and mechanical properties of recycled PCC aggregate concrete. Report DTFH61-93-C-00133. Washington D.C: Federal Highway Administration, U.S. Department of Transportation, 1997.

SÖDERLUND, M., MUENCH, S. T., WILLOUGHBY, K., UHLMEYER, J., \& WESTON, J. Green Roads: A sustainability rating system for roadways. Washington D.C.: 2008. Disponível em:

$<$ http://pavementinteractive.org/images/2/29/Green roads trb paper.pdf $>$. Acesso em: 22 jul. 2010.

SPRINGENSCHMID, R.; SODEIKAT, C. High-quality concrete with recycled aggregates. In: INTERNATIONAL SYMPOSIUM ON CONCRETE ROADS, 8., 1998, Lisboa.

STEIGENBERGER, J. Concrete Roads in Austria - the newest trends and developments. In: INTERNATIONAL CONCRETE ROADS CONFERENCE, Bratislava, 2003. Proceedings. Bratislava: AIPCR-PIARC, CEMBUREAU, ATIC, 2003.

STURTEVANT, J.R.; GRESS, D.L.; SNYDER, M.B. Performance of rigid pavements containing recycled concrete aggregates - 2006 update. Washington, D.C.: Federal Highway Administration Report, 2008.

STURTEVANT, J. R. Performance of rigid pavements containing recycled concrete aggregates. 2006. 139p. Thesis (Master of Science) - University of New Hanpshire, New Hampshire, USA, 2007.

TAM, V. W. Y.; GAO, X.F.; TAM, C. M. Micro-Structural analysis of recycled aggregate concrete produced from two-stage mixing approach. Cement and Concrete Research, v. 35, n. 6, p. 1195-1203, June 2005. 
TAM, V. W. Y.; TAM, C. M. Diversifying two-stage mixing Approach (TSMA) for recycled aggregate concrete: TSMAS and TSMASC. Construction and Building Materials, v. 22, n. 10, p. 2068-2077, Oct. 2008.

TAM, V. W. Y.; TAM, C. M.; WANG, Y. Optimization on proportion for recycled aggregate in concrete using two-stage mixing approach. Construction and Building Materials, v. 21, n. 10, p. 1928-1939, Oct. 2007.

TFB. Les routes em béton modernes. Ruschlikon: Technische Forschung und Beratung fur Zement und Beton, 2000. Disponível em:

$<$ http://www.tfb.ch/htdocs/Files/CB/French/BCF 0007 08.pdf>. Acesso em: 7 abr. 2010.

THE FREEDONIA GROUP. World construction aggregates: industry study with forecasts for 2013 \& 2018. Cleveland: The Freedonia Group, 2009. Disponível em: <http://www.freedoniagroup.com/brochure/25xx/2564smwe.pdf $>$. Acesso em: 7 abr. 2010.

TOMPKINS, D.; KHAZANOVICH, L.; DARTER, M.I. Composite pavement European tour - Chapter 1: recommendations. Washington, D.C.: Federal Highway Administration, U.S. Department of Transportation, 2008.

UCHIKAWA, H.; HANEHARA, S. Recycling of concrete waste. In: CONCRETE FOR EVIRONMENT ENHANCEMENT AND PROTECTION, 1996, Dundee, UK. Concrete in the service of mankind: concrete for environment enhancement and protection. London: 1996.

ULSEN, C. Caracterização tecnológica de resíduos de construção e demolição. 2006. 171p. Dissertação (Mestrado) - Escola Politécnica, Universidade de São Paulo, São Paulo, 2006.

UNITED STATES DEPARTMENT OF TRANSPORTATION Transportation applications of recycled concrete aggregate. Washington, D.C.: FHWA State of the practice national review, 2004.

VALDUGA, L. et al. Influência da forma do agregado, da relação água/cimento e da consistência da argamassa na verificação da potencialidade reativa do agregado. In: CONGRESSO BRASILEIRO DO CONCRETO, 47., 2005, Vitória. Anais. São Paulo: Ibracon, 2005. CD-ROM. 
VANCURA, M.; KHAZANOVICH, L.; TOMPKINS, D. Reappraisal of recycled concrete aggregate as coarse aggregate in concretes for rigid pavements.

Transport Research Record, v. 2113, n. 27, p. 149-155, Nov. 2009.

WON, M. C. Use of crushed concrete as coarse aggregates in concrete pavement. In: INTERNATIONAL WORKSHOP ON BEST PRACTICES FOR CONCRETE PAVEMENTS, 2007, Recife. Proceedings. São Paulo: Ibracon-ISCP, 2007. CDROM.

WERNER, R. Roadway Pavements of Recycled Concrete. In: INTERNATIONAL SYMPOSIUM ON CONCRETE ROADS, 7., 1994, Viena. Cimeurope s.a.r.l., 1994. Disponível em:

$<$ www.betonstrassen-info.ch/file/Fahrbahndecken aus Recyclingbeton.pdf $>$ Acesso em: 14 jul. 2010.

WOLF, T. E FLEISCHER, W. Moderner Betonstraßenbau in Deutschland. In: INTERNATIONAL CONFERENCE ON CONCRETE ROADS, Proceedings. Bratislava, 2007.

YANG, K.H.; CHUNG, H. S.; ASHOUR, A.F. Influence of type and replacement level of recycled aggregates on concrete properties. ACI Materials Journal, n. 105, n. 3, p. 289-296, May 2008.

YOSHIDA, R.; FRAZÃO, E. B.; GIROLDO, A. M. P. Estudo sobre a forma de agregados rochosos. In: SEMANA PAULISTA DE GEOLOGIA APLICADA, 4., 1972, São Paulo. Anais.São Paulo: Associação Paulista de Geologia Aplicada, 1972, p. 285-306.

YRJANSON, W. A. NCHRP Synthesis 154: Recycling of Portland cement concrete pavements. Transportation Research Board, National Research Council, Washington, D.C., 1989.

ZAHARIEVA, R. et al. Assessment of the surface permeation properties of recycled aggregate concrete. Cement \& Concrete Composites, v. 25, n. 2, p. 223-232, 2003. 


\section{ANEXO A - CARACTERIZAÇÃO DOS AGREGADOS RECICLADOS}

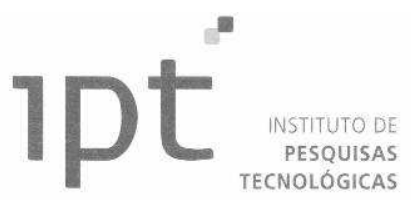

Laboratório de Materiais de Construção Civil / CT-Obras

\section{RELATÓRIO DE ENSAIO Nº 1010 145-203}

CLIENTE: Escola Politécnica da Universidade de São Paulo - PROAP 2009 Avenida Prof. Luciano Gualberto, Travessa 3, $n^{\circ} 380$ - Butantã 05508-010 - São Paulo, SP

MATERIAL: Uma amostra de concreto britado.

NATUREZA DO TRABALHO: Ensaios de caracterização.

REFERÊNCIA: Orçamento CT-OBRAS/LMCC-P 061/10, de 04.05.2010 e Aprovação de 11.05.2010.

\section{MATERIAL}

1.1 Designação: Agregado Reciclado

1.2 Identificação do laboratório: LMCC-P 135/10

1.3 Descrição: Agregado graúdo e miúdo de cor cinza claro.

1.4 Quantidade: aproximadamente $10 \mathrm{~kg}$.

1.5 Procedência informada pelo Cliente: Rodoanel - São Paulo, SP.

\section{MÉTODOS UTILIZADOS}

2.1 Procedimento CT-OBRAS/LMCC-P-PE-010 "Análise granulométrica por peneiramento", de acordo com a norma NBR NM 248/03 - "Agregados Determinação da composição granulométrica", da Associação Brasileira de Normas Técnicas - ABNT.

\section{Equipamentos:}

Balança eletrônica marca Micronal (BAL-05), capacidade nominal $360 \mathrm{~g}$, resolução $0,001 \mathrm{~g}$ (até $60 \mathrm{~g}$ ) e $0,01 \mathrm{~g}$ (acima de $60 \mathrm{~g}$, inclusive). Calibração válida até 20.06.2010, certificado 87620-101 (Laboratório RBC 0003). Patrimônio $n^{\circ}$ 31.566. CT-OBRAS/LMCC-P.

Jogo de peneiras marca "A Bronzinox", de malha quadrada e caixilhos metálicos, calibradas em 29.09.2009 (validade até 10.2010) e Certificados de Calibração $n^{\text {os }} 16074$ a 16093, expedido pela Rede Brasileira de Calibração Laboratório Credenciado pelo INMETRO sob n ${ }^{\circ} 075$. 


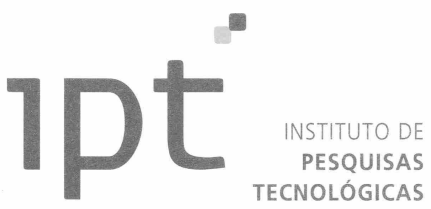

Estufa de secagem marca Fanem, modelo 315/5. Patrimônio $n^{0} 03.131$. CT-OBRAS/LMCC-P.

2.2 Procedimento CT-OBRAS/LMCC-P-PE-028 - "Apreciação petrográfica de materiais naturais", de acordo com a norma NBR 7389/09-1 - "Agregados Análise petrográfica de agregado para concreto. Parte1: Agregado miúdo", da ABNT e, para o agregado graúdo utilizou-se a norma NBR 7389/92 "Apreciação petrográfica de materiais naturais para utilização como agregado em concreto", da ABNT, a pedido do cliente.

Equipamento:

Lupa estereoscópica marca Wild, modelo M-8 (LUP-05). Patrimônio n 21.588. CT-OBRAS/LMCC-P.

Nota: Para efeito de arredondamento, nos cálculos efetuados, foi utilizada a norma ABNT NBR 5891/77 Regras de Arredondamento na Numeração Decimal.

\section{RESULTADOS}

Os resultados estão assim apresentados:

3.1 Análise granulométrica: TABELAS 1 e 2; e GRÁFICOS 1 e 2, ANEXO;

3.2 Apreciação petrográfica de agregado graúdo: TABELA 3, ANEXO.

3.3 Apreciação petrográfica de agregado miúdo: TABELA 4, ANEXO.

\section{ANEXO}

Tabelas 1 a 4 e Gráficos 1 e 2 05 pág.

\section{EQUIPE TÉCNICA}

Priscila Melo Leal Menezes - Geóloga, Mestre Jilson Cardoso - Técnico

São Paulo, 15 junho de 2010.
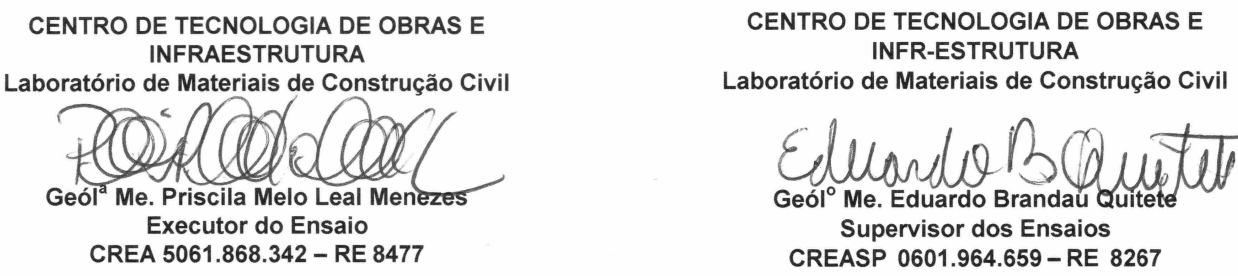

CREASP 0601.964.659-RE 8267

PMLM 
Tabela 1 - Resultados da análise granulométrica do agregado graúdo (NBR NM 248/03) para a amostra "Agregado reciclado" (LMCC-P 135/10) - finalizada em 19.05.2010.

\begin{tabular}{c|c|c}
\hline \multirow{2}{*}{ Peneira $(\mathbf{m m})$} & \multicolumn{2}{|c}{ Porcentagem retida } \\
\cline { 2 - 3 } & Simples & Acumulada \\
\hline 31,5 & 0,0 & 0,0 \\
\hline 25 & 3,1 & 3,1 \\
\hline 19 & 31,3 & 34,4 \\
\hline 12,5 & 34,0 & 68,4 \\
\hline 9,5 & 11,5 & 80,0 \\
\hline 6,3 & 12,2 & 92,1 \\
\hline 4,75 & 5,0 & 97,1 \\
\hline 2,4 & 2,3 & 99,4 \\
\hline 1,18 & 0,2 & 99,6 \\
\hline 0,6 & 0,1 & 99,7 \\
\hline 0,3 & 0,1 & 99,8 \\
\hline 0,15 & 0,1 & 99,9 \\
\hline$<0,15$ & 0,1 & 100,0 \\
\hline
\end{tabular}

Classificação (conforme NBR 7211/05): fora dos limites

Módulo de Finura: 7,10 Dimensão Máxima característica: $25,0 \mathrm{~mm}$

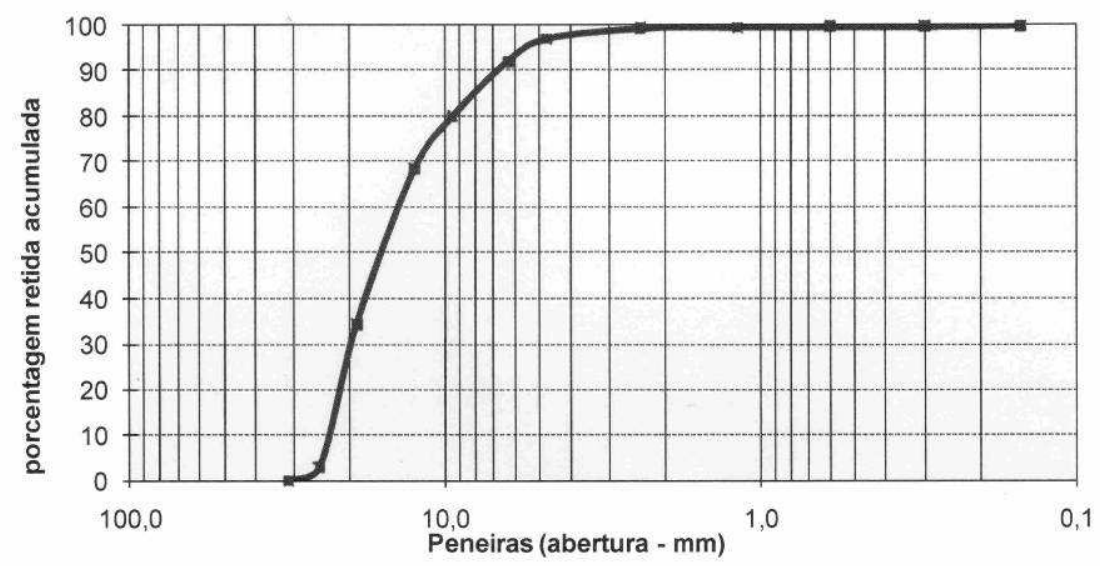

Gráfico 1 - Distribuição granulométrica da amostra para a amostra "Agregado reciclado" (LMCC-P 135/10), conforme TABELA 1. 
Tabela 2 - Resultados da análise granulométrica do agregado miúdo (NBR NM 248/03) para a amostra "Agregado reciclado" (LMCC-P 135/10) - finalizada em 19.05.2010.

\begin{tabular}{c|c|c}
\hline \multirow{2}{*}{ Peneira (mm) } & \multicolumn{2}{|c}{ Porcentagem retida } \\
\cline { 2 - 3 } & Simples & Acumulada \\
\hline 4,75 & 0,0 & 0,0 \\
\hline 2,4 & 0,8 & 0,8 \\
\hline 1,18 & 27,4 & 28,2 \\
\hline 0,6 & 28,5 & 56,8 \\
\hline 0,3 & 19,2 & 75,9 \\
\hline 0,15 & 12,0 & 88,0 \\
\hline$<0,15$ & 12,0 & 100,0 \\
\hline \multicolumn{3}{c}{ Classificação (conforme NBR 7211/05): zona utilizável } \\
\multicolumn{2}{c}{ Módulo de Finura: 2,50 Dimensão Máxima característica: $2,4 \mathrm{~mm}$} \\
\hline
\end{tabular}

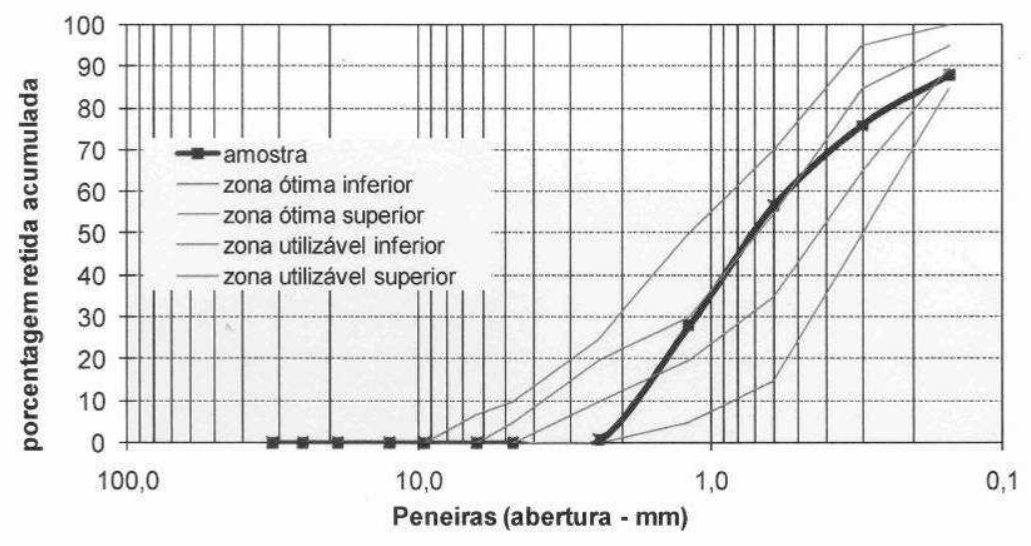

Gráfico 2 - Distribuição granulométrica da amostra para a amostra "Agregado reciclado" (LMCC-P 135/10), conforme TABELA 1. 
Laboratório de Materiais de Construção Civil / CT-Obras

Tabela 3 - Resultados da apreciação petrográfica (ABNT NBR 7389/92) da amostra "Agregado reciclado" (LMCC-P 135/10), finalizada em 11.06.2010.

\begin{tabular}{l|l|l}
\hline \multirow{2}{*}{ COR } & Seco & Cinza claro levemente amarelado \\
\cline { 2 - 3 } ESTRUTURA & Cinza claro levemente esverdeado \\
\hline TEXTURA & $\begin{array}{l}\text { Vesicular (bolhas de ar na pasta de cimento) e } \\
\text { conglomerática (concreto como um todo) }\end{array}$ \\
\hline $\begin{array}{l}\text { ESTADO } \\
\text { ALTERAÇÃO }\end{array}$ & $\begin{array}{l}\text { Cimentada (agregados rochosos cimentados por pasta de } \\
\text { cimento) }\end{array}$ \\
\hline FORMA & Sã (agregado e pasta) \\
\hline $\begin{array}{l}\text { PROPRIEDADES } \\
\text { MECÁNICAS }\end{array}$ & PredomicO- & Coerente (fragmenta-se com martelo) \\
\hline $\begin{array}{l}\text { ENSAIO QUIMICO } \\
\text { COMPOSICCÃO } \\
\text { MINERALÓGICA }\end{array}$ & Reagente ao HCl 10\% frio (pasta de cimento) \\
\hline CLASSIFICAÇÃO & Agregado: quartzo, feldspato e biotita \\
\hline $\begin{array}{l}\text { INDICAÇÃO } \\
\text { ENSAIOS } \\
\text { COMPLEMENTARES }\end{array}$ & Agregado: Biotita gnaisse \\
\hline
\end{tabular}

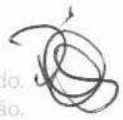


Laboratório de Materiais de Construção Civil / CT-Obras

Tabela 4 - Resultados da apreciação petrográfica (ABNT NBR 7389/09 - Parte 1) da amostra "Agregado reciclado" (LMCC-P 135/10), finalizada em 14.06.2010.

\begin{tabular}{|c|c|c|c|c|c|c|c|c|c|}
\hline \multirow{3}{*}{$\begin{array}{c}\text { peneira } \\
\text { (aber- } \\
\text { tura em } \\
\mathrm{mm} \text { ) }\end{array}$} & \multirow{2}{*}{\multicolumn{2}{|c|}{$\begin{array}{l}\text { porcentagem } \\
\text { retida em peso }\end{array}$}} & \multicolumn{7}{|c|}{$\begin{array}{l}\text { composição mineralógica do material retido } \\
\text { (\% em número de grãos) }\end{array}$} \\
\hline & & & \multicolumn{3}{|c|}{ inócuos } & \multirow{2}{*}{$\begin{array}{c}\begin{array}{c}\text { potencial- } \\
\text { mente } \\
\text { deletério }\end{array} \\
\begin{array}{c}\text { Fragmento } \\
\text { de } \\
\text { concreto }\end{array} \\
\end{array}$} & \multicolumn{2}{|c|}{ friáveis } & \multirow{2}{*}{$\begin{array}{l}\text { total } \\
\text { na } \\
\text { fra- } \\
\text { ção }\end{array}$} \\
\hline & $\begin{array}{l}\text { sim- } \\
\text { ples }\end{array}$ & $\begin{array}{l}\text { acumu- } \\
\text { lada }\end{array}$ & $\begin{array}{l}\text { frag- } \\
\text { mento de } \\
\text { rocha } \\
\text { gnáis- } \\
\text { sica } \\
\end{array}$ & $\begin{array}{l}\text { quartzo } \\
\text { leitoso e } \\
\text { translúci- } \\
\text { do }^{1}\end{array}$ & $\begin{array}{l}\text { Felds- } \\
\text { pato } \\
\text { são }\end{array}$ & & $\begin{array}{l}\text { torrão } \\
\text { de argila } \\
\text { rosa/la- } \\
\text { ranja }\end{array}$ & micas $^{3}$ & \\
\hline 2,4 & 0,8 & 0,8 & 29,0 & 7,5 & 5,0 & 58,1 & 0,4 & 0,0 & 100,0 \\
\hline 1,18 & 27,4 & 28,2 & 17,5 & 16,2 & 6,5 & 59,9 & 0,0 & 0,0 & 100,0 \\
\hline 0,6 & 28,5 & 56,8 & 10,7 & 27,4 & 6,0 & 54,6 & 0,0 & 1,3 & 100,0 \\
\hline 0,3 & 19,2 & 75,9 & 0,0 & 35,0 & 2,4 & 54,1 & 0,0 & 8,5 & 100,0 \\
\hline 0,15 & 12,0 & 88,0 & 0,0 & 55,1 & 0,0 & 36,7 & 0,0 & 8,2 & 100,0 \\
\hline$<0,15$ & 12,0 & 100,0 & - & - & $\begin{array}{l}- \\
\end{array}$ & - & - & - & $\begin{array}{l}- \\
\end{array}$ \\
\hline TOTAL & 100,0 & TOTAL* & 8,1 & 32,3 & 4,0 & 51,7 & 0,0 & 4,0 & 100,0 \\
\hline
\end{tabular}

NOTA:

- = fração não analisada

* = total aproximado na amostra, calculado em função da porcentagem em peso retida em cada fração, considerando-se que a composição do material $<0,15 \mathrm{~mm}$ é igual à do material retido na peneira $0,15 \mathrm{~mm}$

Esfericidade predominante: Baixa

Arredondamento predominante: Anguloso

Superfície predominante: Rugosa

\section{Comentários:}

A amostra areia (LMCC-P 135/10) apresenta mineralogia e características morfológicas adequadas à utilização como agregado miúdo em concreto, conforme a NBR 7211. Porém deve-se ter especial cuidado com os fragmentos de concreto, pois o mesmo deve ser caracterizado com vistas à potencialidade de reação álcali-agregado pelo conteúdo de álcalis normalmente presentes na pasta de cimento. $\mathrm{O}$ uso de resíduos da construção (RCD) deve atender a norma NBR 15116.

\footnotetext{
${ }^{1}$ Predomínio de quartzo leitoso até $0,60 \mathrm{~mm}$, após esta fração, predomina quartzo translúcido.

${ }^{2} \mathrm{Na}$ fração $0,15 \mathrm{~mm}$, o fragmento de concreto corresponde totalmente a fragmentos de pasta de cimento.

${ }^{3}$ Micas = biotita e clorita na fração $0,15 \mathrm{~mm}$
} 


\section{ANEXO B - RESULTADOS DO ENSAIO DE DETERMINAÇÃO DO TEOR DE PASTA DE CIMENTO}

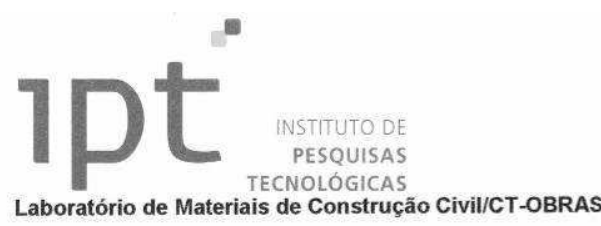

RELATÓRIO DE ENSAIO N. ${ }^{\circ} 1010$ 274-203

CLIENTE: ESCOLA POLITÉCNICA DA UNIVERSIDADE DE SÃO PAULO

Av. Prof. Luciano Gualberto, 380 - Travessa 3 - Butantã

CEP 05508-010 - São Paulo - SP

NATUREZA DO TRABALHO: Determinação de resíduo insolúvel

REFERÊNCIA: Orçamento CT-Obras/LMCC-Q N. 050/10 de 10.05.2010 e Aprovação do orçamento de 20.05 .2010

1 MATERIAL

Dois (02) materiais identificados pelo Cliente como "RCD amostra 1 - finos moídos" e "RCD amostra 2 - graúdos moídos", recebidos no Laboratório de Materiais de Construção Civil (LMCC) do IPT em 18.05.2010, pesando aproximadamente 0,5kg e identificados no laboratório como LMCC-Q N. ${ }^{\circ} 25.027$ e 25.028 , respectivamente.

\section{MÉTODO UTILIZADO}

Resíduo insolúvel: Procedimento CT-OBRAS-LMCC-Q-PE-042 "Concreto e Argamassa - Reconstituição de traço", com base em diretrizes gerais do Método "Reconstituição do traço do concreto". Métodos de análises químicas adotados no IPT. Boletim... São Paulo: IPT, setembro 1940, n. ${ }^{\circ} 25$, p. $75-84$.

Nota 1: Após a solubilização das amostras o resíduo insolúvel foi seco a $105^{\circ} \mathrm{C}$, até massa constante, conforme solicitado pelo Cliente.

\section{RESULTADOS}

Os resultados de ensaio estão apresentados a seguir:

- "RCD amostra 1 - finos moídos" (LMCC-Q № 25.027): 71,0\%.

- "RCD amostra 2 - graúdos moídos" (LMCC-Q N 25.028): 77,8\%.

São Paulo, 18 de junho de 2010.
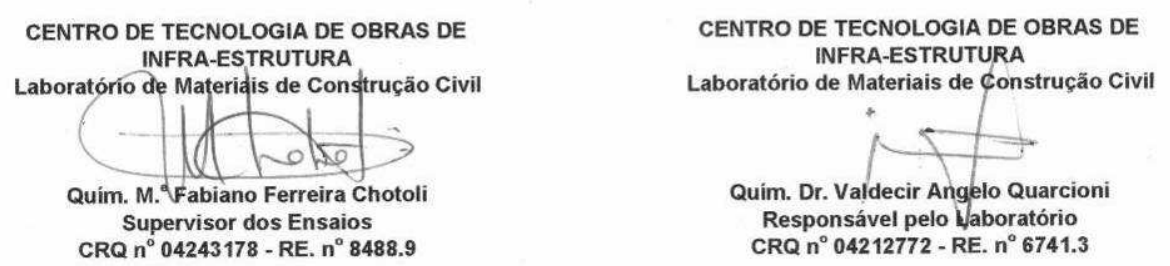


\section{ANEXO C - EXEMPLO DE TRATAMENTO DE DADOS DOS RESULTADOS OBTIDOS NO ENSAIO DE ABSORÇÃO PROPOSTO POR DAMINELI (2007)}

Amostra de agregados miúdos gerados na produção de agregados graúdos de dimensão máxima $25 \mathrm{~mm}$

\begin{tabular}{|c|c|c|c|}
\hline$t(40 s)$ & M CONJUNTO & TEOR UMIDADE (\%) & TAXA SECAGEM (g/20s) \\
\hline 1 & 359.7 & 47,18 & \\
\hline 2 & 358.7 & 46,77 & 1 \\
\hline 3 & 355.7 & 45,54 & 3 \\
\hline 4 & 351.9 & 43,99 & 3,8 \\
\hline 5 & 345.7 & 41,45 & 6,2 \\
\hline 6 & 339.6 & 38,95 & 6,1 \\
\hline 7 & 333.3 & 36,37 & 6,3 \\
\hline 8 & 326.8 & 33,72 & 6,5 \\
\hline 9 & 320.2 & 31,01 & 6,6 \\
\hline 10 & 313.7 & 28,36 & 6,5 \\
\hline 11 & 307.3 & 25,74 & 6,4 \\
\hline 12 & 300.9 & 23,12 & 6,4 \\
\hline 13 & 294.8 & 20,62 & 6,1 \\
\hline 14 & 288.6 & 18,09 & 6,2 \\
\hline 15 & 282.6 & 15,63 & 6 \\
\hline 16 & 276.5 & 13,13 & 6,1 \\
\hline 17 & 270.5 & 10,68 & 6 \\
\hline 18 & 264.4 & 8,18 & 6,1 \\
\hline 19 & 258.7 & 5,85 & 5,7 \\
\hline 20 & 254.3 & 4,05 & 4,4 \\
\hline 21 & 250.9 & 2,66 & 3,4 \\
\hline 22 & 248.3 & 1,60 & 2,6 \\
\hline 23 & 246.2 & 0,74 & 2,1 \\
\hline 24 & 244.4 & 0,00 & 1,8 \\
\hline 25 & 243.0 & $-0,57$ & 1,4 \\
\hline 26 & 241.6 & $-1,15$ & 1,4 \\
\hline 27 & 240.5 & $-1,60$ & 1,1 \\
\hline 28 & 239.6 & $-1,96$ & 0,9 \\
\hline 29 & 238.8 & $-2,29$ & 0,8 \\
\hline 30 & 238.1 & $-2,58$ & 0,7 \\
\hline 31 & 237.4 & $-2,86$ & 0,7 \\
\hline 32 & 236.8 & $-3,11$ & 0,6 \\
\hline 33 & 236.3 & $-3,31$ & 0,5 \\
\hline 34 & 235.9 & $-3,48$ & 0,4 \\
\hline 35 & 235.5 & $-3,64$ & 0,4 \\
\hline 36 & 235.1 & $-3,81$ & 0,4 \\
\hline 37 & 234.8 & $-3,93$ & 0,3 \\
\hline 38 & 234.5 & $-4,05$ & 0,3 \\
\hline 39 & 234.3 & $-4,13$ & 0,2 \\
\hline 40 & 234.0 & $-4,26$ & 0,3 \\
\hline
\end{tabular}




\begin{tabular}{|c|c|c|c|}
\hline $\mathbf{t}(\mathbf{4 0 s})$ & M CONJUNTO & TEOR UMIDADE (\%) & TAXA SECAGEM (g/20s) \\
\hline 41 & 233.8 & $-4,34$ & 0,2 \\
\hline 42 & 233.7 & $-4,38$ & 0,1 \\
\hline 43 & 233.5 & $-4,46$ & 0,2 \\
\hline 44 & 233.3 & $-4,54$ & 0,2 \\
\hline 45 & 233.2 & $-4,58$ & 0,1 \\
\hline 46 & 233.1 & $-4,62$ & 0,1 \\
\hline 47 & 233.0 & $-4,66$ & 0,1 \\
\hline 48 & 232.9 & $-4,71$ & 0,1 \\
\hline 49 & 232.8 & $-4,75$ & 0,1 \\
\hline 50 & 232.7 & $-4,79$ & 0,1 \\
\hline 51 & 232.6 & $-4,83$ & 0,1 \\
\hline 52 & 232.6 & $-4,83$ & 0 \\
\hline 53 & 232.5 & $-4,87$ & 0,1 \\
\hline 54 & 232.4 & $-4,91$ & 0,1 \\
\hline 55 & 232.4 & $-4,91$ & 0 \\
\hline 56 & 232.3 & $-4,95$ & 0,1 \\
\hline 57 & 232.3 & $-4,95$ & 0,1 \\
\hline 58 & 232.2 & $-4,99$ & \\
\hline
\end{tabular}

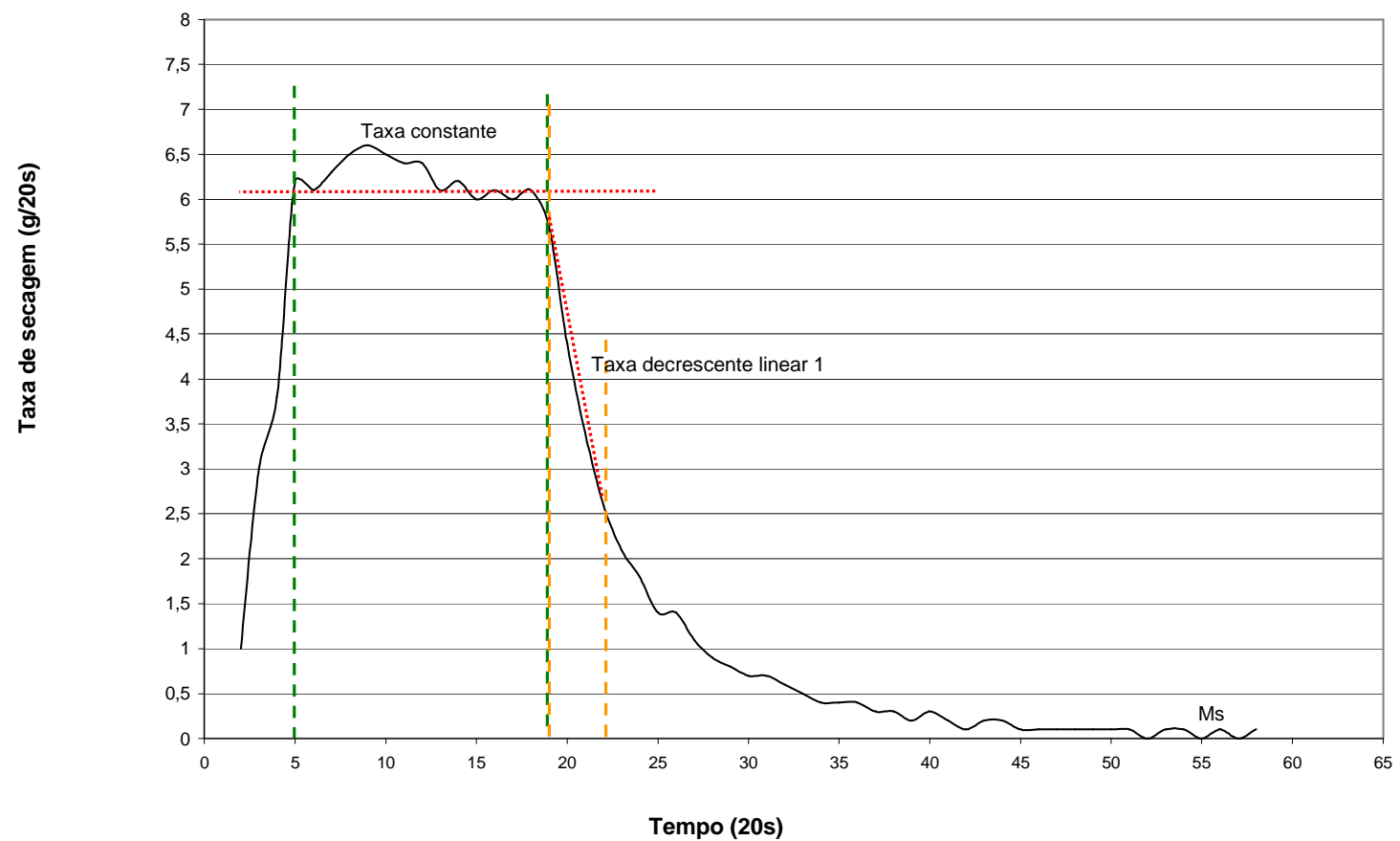

Determinação da massa seca (Ms)

Taxa secagem constante nula

Taxa secagem

$y=-1,15$

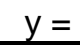

0

decrescente linear 2

$\mathbf{x}=23,91$ tempo $t$ em que ocorre a Ms

$\mathrm{Ms}=244,4$ 

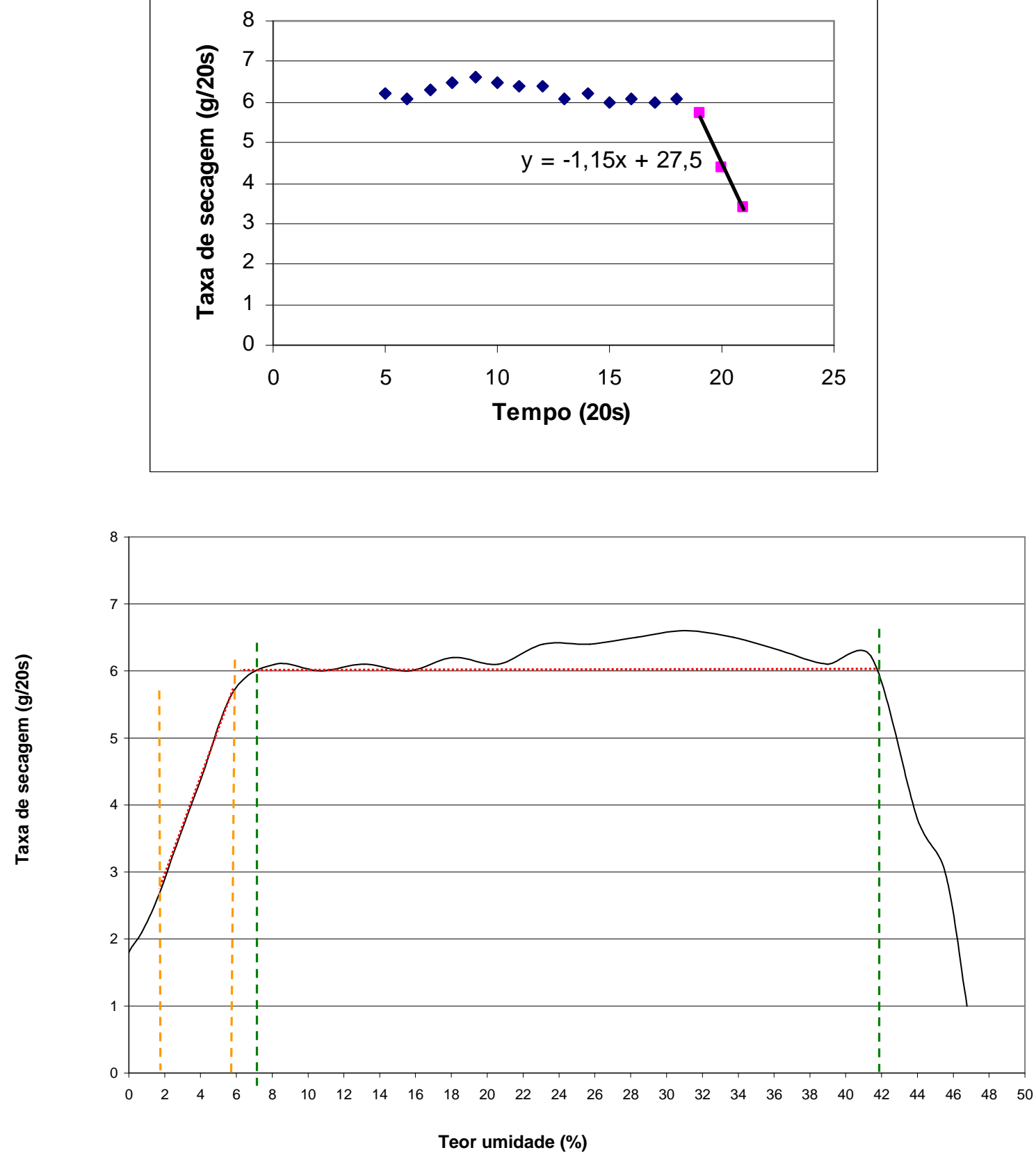

Determinação da absorção matematicamente

Taxa secagem constante linear

$y=$ 6,25

Taxa secagem

$\begin{aligned} & \mathrm{y} \\ & =\end{aligned} \quad 0,7269$ decrescente linear 1

\begin{tabular}{cc|}
$x+$ & 1,4522 \\
\cline { 2 - 2 }$=$ & $\mathbf{6 , 6 0}$ \\
\cline { 1 - 1 }$=$ & 260,53127 \\
Absorção
\end{tabular}




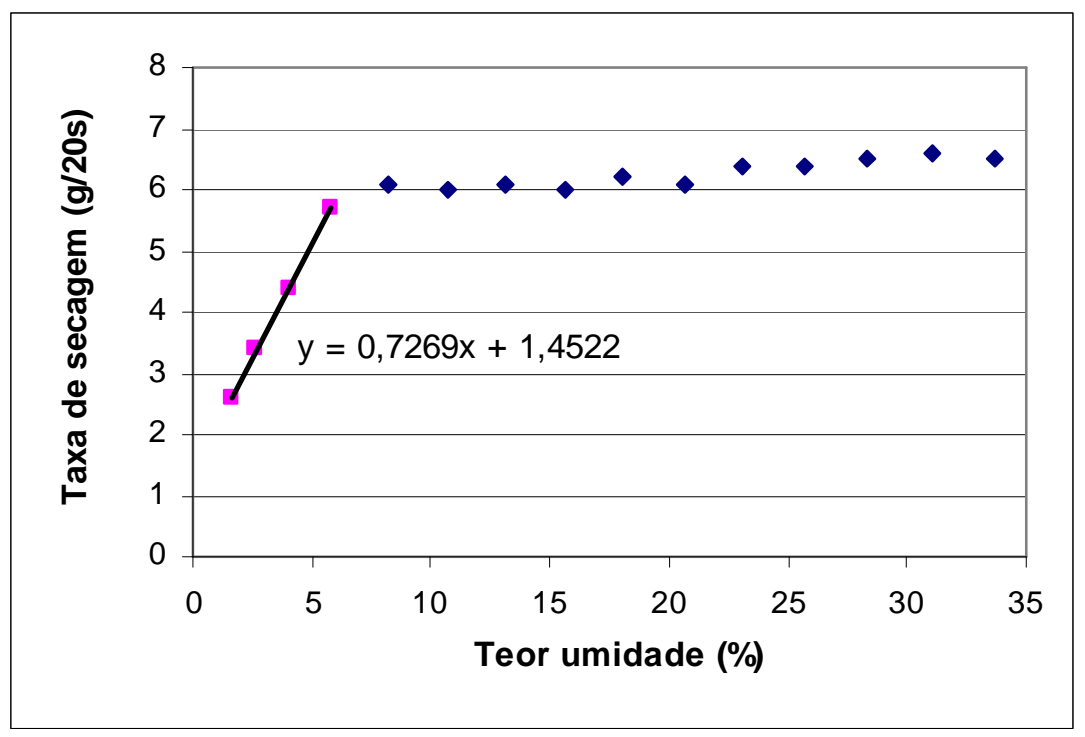

\begin{tabular}{|c|c|c|}
\hline GRANDEZAS & UNID, & VALOR \\
\hline Ms micro & $\mathrm{g}$ & 244,4 \\
\hline Msub & $\mathrm{g}$ & 145,45 \\
\hline Msss & $\mathrm{g}$ & 260,5 \\
\hline Vsol & $\mathrm{cm}^{3}$ & 99,0 \\
\hline Vap & $\mathrm{cm}^{3}$ & 115,1 \\
\hline Vporos & $\mathrm{cm}^{3}$ & 16,1 \\
\hline
\end{tabular}

\begin{tabular}{|c|c|c|}
\hline GRANDEZAS & UNID, & VALOR \\
\hline MER & $\mathrm{g} / \mathrm{cm}^{3}$ & 2,47 \\
\hline MEA & $\mathrm{g} / \mathrm{cm}^{3}$ & 2,12 \\
\hline Abs & $\%$ & 6,60 \\
\hline
\end{tabular}

